UNIVERSIDADE DE SÃO PAULO

FACULDADE DE ECONOMIA, ADMINISTRAÇÃO E CONTABILIDADE DEPARTAMENTO DE ADMINISTRAÇÃO

GOVERNANÇA INSTITUCIONAL:

UM ESTUDO DO PAPEL E DA OPERAÇÃO DOS CONSELHOS

DAS ORGANIZAÇÕES DA SOCIEDADE CIVIL

NO CONTEXTO BRASILEIRO

Antonio Luiz de PaUla e Silva

Orientador: Prof. Dr. Eduardo Pinheiro Gondim de Vasconcellos

São Paulo, SP, Brasil 


\author{
Reitor da Universidade de São Paulo \\ Prof. Dr. Jacques Marcovitch \\ Diretor da Faculdade de Economia, Administração e Contabilidade \\ Prof. Dr. Eliseu Martins \\ Chefe do Departamento de Administração \\ Prof. Dr. Cláudio Felisoni de Angelo
}


UNIVERSIDADE DE SÃO PAULO

FACULDADE DE ECONOMIA, ADMINISTRAÇÃO E CONTABILIDADE

DEPARTAMENTO DE ADMINISTRAÇÃO

GOVERNANÇA INSTITUCIONAL:

\title{
UM ESTUDO DO PAPEL E DA OPERAÇÃO DOS CONSELHOS \\ DAS ORGANIZAÇÕES DA SOCIEDADE CIVIL \\ NO CONTEXTO BRASILEIRO
}

\author{
Antonio Luiz de Paula e Silva \\ Orientador: Prof. Dr. Eduardo Pinheiro Gondim de Vasconcellos \\ Dissertação de mestrado apresentada ao Departamento \\ de Administração da Faculdade de Economia, \\ Admi nistração e Contabilidade da Universidade de São \\ Paulo como requisito parcial para a obtenção do título de \\ Mestre em Administração.
}

Abril, 2001 
Paula e Silva, Antonio Luiz de

Governança institucional : um estudo do papel e da operação dos conselhos das organizações da sociedade civil no contexto brasileiro / Antonio Luiz de Paula e Silva. Paulo : FEA/USP, 2001.

p.

Dissertação - Mestrado

Bibliografia

1. Conselhos de administração 2. Governança 3. Empresas não lucrativas - Administração I. Faculdade de Economia, Administração e Contabilidade da USP

$$
\text { CDD - } 658.422
$$




\section{DEDICATÓRIA}

A meus pais.

À minha mulher Rose e meu filho João Pedro.

"O QUE NÃO SE DÁ, SE PERDE."

(HASARI PAL) 


\section{AgRADECIMENTOS}

A Rose e João Pedro, que abriram mão de muitas coisas para que eu pudesse dar este passo.

Ao meu pai, pelo carinho com que me recebeu na fase final desta tarefa.

Ao Prof. Eduardo Vasconcellos, pela disponibilidade, atenção, orientação e "duras" na hora certa.

A todas as pessoas e organizações da Rede Nossas Crianças que forneceram dados e depoimentos para esta pesquisa, por ceder um pouco do que é seu para que outros pudessem aprender.

À equipe do Programa Nossas Crianças, da Fundação Abrinq pelos Direitos das Crianças - Itamar, Cida, Andrea, Gabriel e Denise - pela abertura, disposição e carinho com que me ajudaram.

Ao conselho do Instituto Christophorus - Vítor, Carla, Alice, Alexandre, Joaquim, Pedro e Max - por terem tido paciência e me ensinado muito sobre a realidade de um conselho.

Ao conselho do Centro Paulus - Jos, Fátima, Túlio, Rogério e Mariangela - por serem tão abertos e corajosos ao meu lado.

À Ashoka, por acreditar no meu projeto e no meu potencial.

A Flora Lovato, pelos comentários, revisões, sugestões, críticas e compartilhar de experiências.

A Eduardo Marino, Silvia Dante, Maria Helena Webster, Evelyn loschpe e Rogério Amato pela generosidade em dividir o que sabem e o que viveram.

À equipe do Instituto Christophorus - Lafayette, Rosana, Ana Paula, Glorialuz, Luba, Tião, Regina, Mário pelo encorajamento e pelos ensinamentos.

Ao Dr. Marcos Kisil, pelo estímulo, orientação e apoio.

À Didi, que sempre esteve pronta para me ajudar.

À toda a equipe da secretaria de pós-graduação, especialmente Valéria e Cristina, pela atenção, cuidado e presteza com que sempre me receberam.

A Marina Carneiro de Oliveira e Daniel Brandão, por serem tão fellows.

A Eliana Vera, que me indicou esta direção.

Ao Prof. Thomas Holland, pelo provimento de informações, materiais e indicações.

Ao $\mathrm{CNPQ}$, pelo investimento financeiro feito há tanto tempo atrás.

Ao NCNB - National Ce nter for Nonprofit Boards, especialmente Lisa McCarthur, pelo suporte e incentivo.

A todos os demais que contribuíram comigo nesta tarefa que durou 4 anos, seja com trabalho, encorajamento ou conhecimento.

Muito obrigado! 


\section{Resumo}

O presente trabalho de pesquisa é motivado pela seguinte pergunta: "Nas condições brasileiras, como devem trabalhar os conselhos diretores das organizações da sociedade civil?". O objetivo geral é ampliar o conhecimento sobre a atuação dos conselhos das organizações da sociedade civil em São Paulo. Para conseguir isso: (a) examinase as práticas de atuação dos conselhos consideradas mais eficazes pela literatura especializada; (b) descreve-se como operam os conselhos de organizações da sociedade civil paulistas que atendem crianças e adolescentes; (c) propõe-se uma série de princípios para fundamentar o comportamento de conselhos eficazes nas condições brasileiras. Foram obtidos depoimentos de 21 pessoas, entre conselheiros e executivos, representando 10 organizações da sociedade civil que trabalham com crianças e/ou adolescentes na região da Grande São Paulo. Nestes depoimentos foi possível analisar 46 incidentes, com profundidades variáveis. Utilizou-se, para levantamento dos dados, da Técnica do Incidente Crítico (FLANAGAN, 1954) e de uma adaptação de um questionário orientado a competências desenvolvido por CHAIT et allii (1991). 


\section{ABstract}

The present research work is motivated by the following question: "In the Brazilian context, how should the civil society organizations' boards work?". The general purpose is to increase the knowledge about the work of the boards in nonprofit organizations in São Paulo. To achieve this: (a) an examination of the most recommended practices from the literature is made; (b) it is described the operation mode of boards from nonprofit organizations that benefit children and youth; (c) a series of principles to orient the behavior of effective boards in the Brazilian context is proposed. The study considered the narrative of 21 people, among board members and executive officers, representing 10 civil society organizations that are working with children and youth in Great São Paulo area. It was possible to build over 46 critical incidents. It used the Critical Incident Technique (FLANAGAN, 1954) and a competency oriented questionnaire developed by CHAIT et allii (1991) for the gathering of data. 


\section{ÍNDICE}

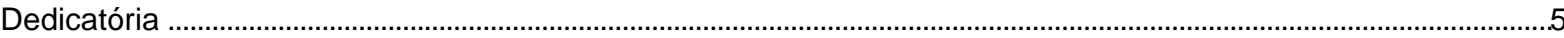

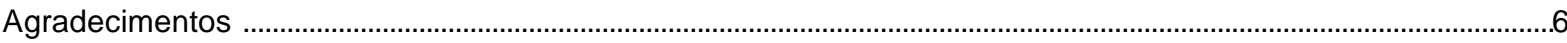

Resumo

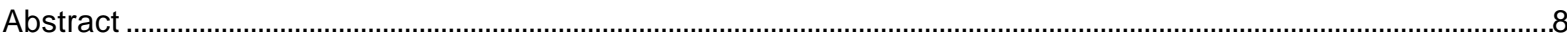

Índice

1 O Propósito deste Trabalho ……………………………............................................................................................11

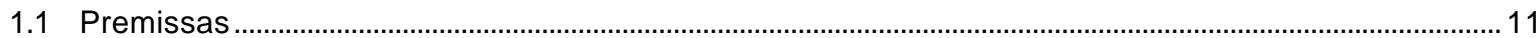

1.2 Características do Estudo............................................................................................................................ 12

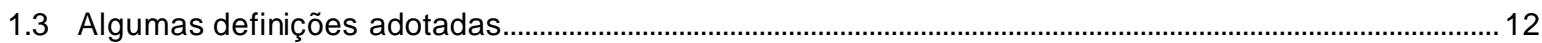

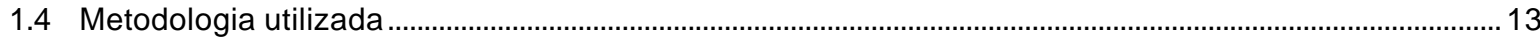

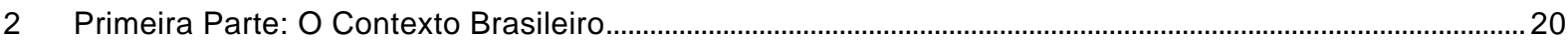

2.1 Reconhecendo o Terceiro Setor ................................................................................................................. 20

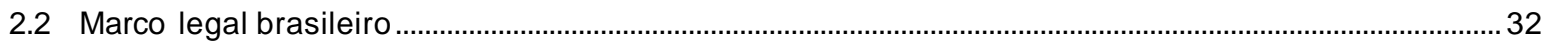

2.3 O que está acontecendo nas Empresas.......................................................................................................... 39

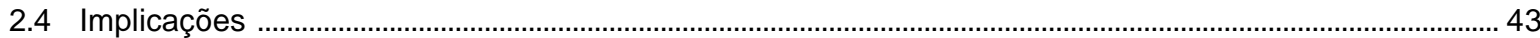

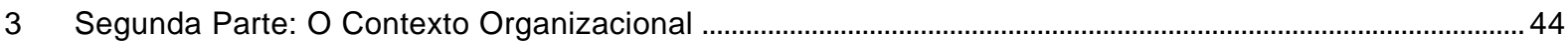

3.1 Raízes históricas da existência de conselhos .................................................................................................. 44

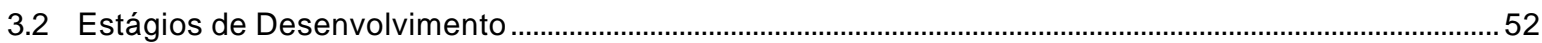

3.3 Distinções a respeito do sistema organizacional.......................................................................................... 61

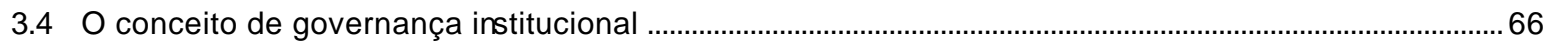

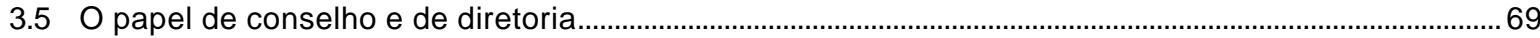

4 Terceira Parte: Exercendo a Governança Institucional ............................................................................................

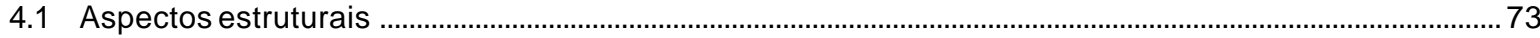

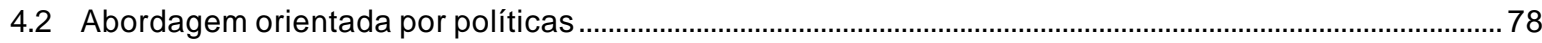

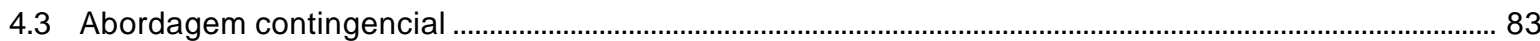

4.4 Abordagem por Competências ou Comportamental .....................................................................................90

5 Quarta Parte: Buscando lições em experiências brasileiras ................................................................................98

5.1 Perfil estatutário das organizações da Rede Nossas Crianças..................................................................98

5.2 Perfil das organizações estudadas .................................................................................................................. 
5.3 Perfil dos conselheiros e executivos entrevistados 103

5.4 Desempenho geral dos conselhos - Análise dos Questionários ........................................................... 105

5.5 Desempenho específico dos conselhos- Análise dos Depoimentos ......................................................114

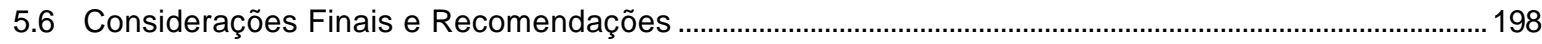

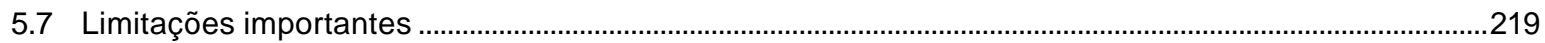

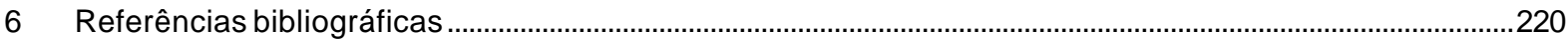

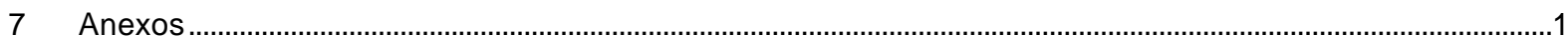

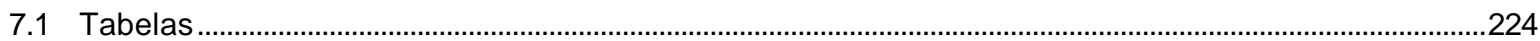

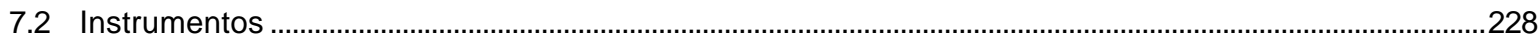




\section{O Propósito deste Trabalho}

O presente trabalho de pesquisa está motivado pela seguinte pergunta: "Nas condições brasileiras, como devem trabalhar os conselhos diretores das organizações da sociedade civil?".

O objetivo geral desta pesquisa é ampliar o conhecimento sobre a atuação dos conselhos das organizações da sociedade civil em São Paulo. Este conhecimento e a identificação das práticas consideradas mais efetivas nas condições brasileiras permitirá desenhar, implementar e avaliar propostas para 0 aprimoramento da atuação dos conselhos deste tipo de organizações no Brasil.

Para conseguir isso, pretende -se:

a) Examinar as práticas de atuação dos conselhos consideradas mais eficazes pela literatura especializada.

Uma vez que ainda existem poucas pesquisas e experiências sistematizadas sobre a operação de conselhos de organizações da sociedade civil no Brasil, durante todo o decorrer do trabalho são relatadas as principais recomendações de especialistas para que os conselhos atuem de forma eficaz. Estas recomendações oferecem parâmetros para avaliar a atuação destas instâncias organizacionais e facilitar a identificação de desvios e acertos.

b) Conhecer como operam os conselhos de organizações da sociedade civil paulistas que atendem crianças e adolescentes.

Procurase, neste estudo, caracterizar como operam os conselhos de entidades que participam do Programa Nossas Crianças, desenvolvido pela Fundação Abrinq pelos Direitos das Crianças.

c) Caracterizar o comportamento de conselhos eficazes nas condições brasileiras.

Através do cruzamento das informações citadas acima, é feita uma discussão exploratória sobre - comportamento dos conselhos nas condições brasileiras. Especialmente, busca-se caracterizar um conjunto de princípios a serem aplicados por conselhos no Brasil, que contribuam para um melhor desempenho das organizações da sociedade civil e de seu impacto social.

Espera-se que o produto deste trabalho possa contribuir para que o potencial dos conselhos seja melhor aproveitado dentro das organizações, influindo positivamente nas suas diretrizes e no seu desempenho, fortalecendo o terceiro setor e trazendo benefícios para a sociedade no longo prazo.

\subsection{PREMISSAS}

A seguinte lista de premissas é assumida para atingir os objetivos propostos nesta pesquisa:

1. Conselhos eficazes podem oferecer contribuições valiosas às suas organizações, que afetam a qualidade e a sustentabilidade da instituição no longo prazo.

2. Existe um corpo de conhecimento que tem evoluído e que favorece o argumento de que certas práticas são melhores do que outras, na maioria das situações. 
3. Existem comportamentos específicos que distinguem conselhos mais eficazes de conselhos menos eficazes.

4. Estes comportamentos podem ser descritos e reconhecidos na prática das instituições.

5. Existe um conjunto de competências e habilidades associadas a esses comportamentos.

\subsection{CARACTERÍ́sticas do ESTUdo}

Este estudo tem caráter:

- Qualitativo: a preocupação central da pesquisa é ampliar a compreensão do problema, utilizando para isso métodos qualitativos; trata-se de assunto com alto grau de subjetividade, não sendo intenção central quantificar ou medir fenômenos;

- Descritivo: porque buscase conhecer e caracterizar como operam os conselhos de uma amostra das organizações da sociedade civil paulistas, não tendo como objetivo comprovar a existência de relações causais e de interdependência;

- Exploratório: porque o assunto em questão foi pouquíssimo estudado no Brasil, havendo ainda escassas informações e dados sobre conselhos de organizações da sociedade civil no país; o estudo visa ampliar o conhecimento e o entendimento sobre o tema e gerar eflexões, hipóteses e perguntas que contribuam para o seu desenvolvimento;

- Ocasional: porque é um estudo pontual, referindo-se a um momento histórico, não considerando mudanças que possam ocorrer ou ter ocorrido com o tempo;

- De campo: porque os dados foram obtidos diretamente com quem trabalha nas organizações da sociedade civil;

- Empírico: porque está orientado à prática de pessoas que atuam no diaa-dia das instituições. O enfoque da pesquisa será comportamental, baseado naquilo que os conselhos fazem no cumprimento de seu papel.

\subsection{ALGUMAS DEFINIÇÕES ADOTADAS}

A pesquisa utiliza-se das seguintes definições operacionais:

$\diamond$ Conselho diretor: órgão dirigente definido em estatuto, sob denominações do tipo "administrativo", "deliberativo", "de administração" ou "diretor", composto por não menos do que três pessoas, que atuam voluntariamente, que acumula funções relacionadas ao governo da organização, interferindo nas suas diretrizes.

$\diamond$ Organizações da sociedade civil: para efeito desta pesquisa são consideradas as organizações que participam da Rede Nossas Crianças, ligada ao Programa Nossas Crianças da Fundação Abrinq pelos Direitos da Criança.

$\diamond$ Conselheiro: membro formal do conselho, voluntário, conforme definido pelo estatuto de cada organização. 
$\diamond$ Executivo: liderança executiva da organização, remunerada ou não, conforme definido pelo estatuto de cada organização.

$\diamond$ Práticas de operação: ações observáveis, que caracterizam o comportamento do conselho no diaadia.

\subsection{Metodologia Utilizada}

$\mathrm{Na}$ escolha do método para esta pesquisa buscourse encontrar procedimentos que permitissem:

$\Rightarrow$ Desenvolver estudos que tenham alguma base empírica;

$\Rightarrow$ Obter fatos reais e não somente opiniões e impressões de pessoas com experiência prática;

$\Rightarrow$ Obter informações de pessoas que participaram diretamente dos eventos práticos, especialmente aquelas na melhor posição possível para fazer observações;

$\Rightarrow$ Examinar em maior profundidade acontecimentos específicos;

$\Rightarrow$ Reduzir a possibilidade de distorções por auto-avaliações;

$\Rightarrow$ Possibilitar a interação direta entre pesquisador e público-alvo da pesquisa.

Em virtude destes critérios utilizou-se, para levantamento dos dados, da Té cnica do Incidente Crítico sistematizada por Flanagan ${ }^{1}$ em 1954.

A Técnica do Incidente Crítico é um método que consiste num conjunto de procedimentos de coleta direta de observações do comportamento humano em situações definidas. A Técnica trata especialmente incidentes observados que tenham significância especial e respeitem critérios sistematicamente determinados. Por incidente crítico entende-se "qualquer atividade humana observável que seja suficientemente completa em si mesma para permitir inferências e predições as serem feitas sobre a pessoa realizando a ação". Um incidente crítico ocorre numa situação em que o propósito ou intento para agir está razoavelmente claro para o observador e suas conseqüências estão suficientemente definidas, deixando pouca dúvida sobre seus efeitos.

"Incidente crítico" pode ainda ser definido como aquele em que houve comportamento extremo, efetivo ou inefectivo, com respeito a obter os objetivos daquela atividade. O procedimento tem considerável eficiência pelo uso de extremos de comportamento. O pressuposto é que pode-se identificar com maior facilidade incidentes extremos do que comportamento considerado razoavelmente regular ou médio.

Segundo Flanagan, "a essência da técnica é que somente tipos simples de julgamentos são requeridos do observador, relatos de apenas observadores qualificados são incluídos e todas as observações são avaliadas pelo observador" a partir de um objetivo predefinido para a atividade.

$\mathrm{Na}$ aplicação da Técnica, o primeiro passo é clarificar os objetivos da atividade a ser observada, pois, de acordo com o autor, "é claramente impossível reportar que uma pessoa tenha sido eficaz ou ineficaz numa atividade particular ao executar uma determinada ação a menos que se saiba o que se esperava

\footnotetext{
${ }^{1}$ 4. FLANAGAN, J. The critical incident Technique. Psichological Bulletin, 51(4), 327-358, 1954.
} 
conseguir". Estes objetivos devem ser determinados pelos próprios participantes, sendo que aqueles considerados mais úteis podem ser expressos mesmo por uma frase simples.

É importante cuidar para que as instruções dadas aos observadores sejam as mais acuradas possíveis, para permitir o maior acesso possível a fatos. Para assegurar objetividade, as seguintes regras se aplicam:

(a) Delimitar a situação a ser observada: local, pessoas, condições, atividades, etc.;

(b) Avaliar se um comportamento específico contribui de alguma formapara o propósito geral da atividade;

(c) Avaliar a amplitude do efeito do incidente sobre os objetivos da atividade, positivo e negativo, idealmente de modo quantitativo ou em termos de probabilidade;

(d) Os observadores devem ser selecionados com base na sua familiaridade com a atividade;

(e) Coletar preferencialmente dados que estejam ainda "frescos na memória", isto é, que possam ser lembrados em detalhes com facilidade, especialmente em situações em que a principal fonte de dados é realmente a memória das pessoas (se detalhes precisos e numerosos são fornecidos, geralmente pode-se assumir que a informação é correta);

(f) Dar preferência a observações diretas.

Quatro procedimentos são considerados relevantes para o uso da Técnica do Incidente Crítico: entrevistas indivi duais, entrevistas em grupo, questionários e relatórios escritos. A qualidade dos dados obtidos por entrevistas individuais é comumente afetada pelo grau de interesse que o observador tem no estudo, pelo próprio propósito do estudo, pela qualificação que o observador tem para responder, pela garantia de anonimidade dos dados, pela qualidade na formulação das questões e pelo grau de permissividade e neutralidade na conversação.

\subsubsection{Amostra}

A amostragem nesta pesquisa foi de natureza não-probabilística, por não ser o objetivo deste trabalho generalizar os dados obtidos, nem haver informações e recursos suficientes para determinar a representatividade da amostra no universo de organizações da sociedade civil paulistas. A amostragem não-probabilística é definida por Mattar $(1997)^{2}$ como "aquela em que a seleção dos elementos da população depende, ao menos em parte, do julgamento do pesquisador ou do entrevistador no campo. Não há nenhuma chance conhecida de que um elemento qualquer da população venha a fazer parte da amostra".

Dentro do universo de organizações da sociedade civil que participam do Programa Nossas Crianças, a amostragem foi feita por conveniência, por ser barata, simples e estar ao alcance deste pesquisador: foi feito um convite verbal e por correio eletrônico a um universo de cerca de 75 entidades ligadas por convênio ou não ao Programa Nossas Crianças para participar da pesquisa. Destas 75, 10 se dispuseram a colaborar. Portanto, neste caso o elemento pesquisado também foi, em parte, auto-selecionado.

\footnotetext{
${ }^{2}$ MATTAR, F.N., Pesquisa de Marketing, volumes 1 e 2. Editora Atlas, São Paulo, 1997.
} 
"Amostras por conveniência (ou acidentais) são selecionadas, como o próprio nome diz, por alguma conveniência do pesquisador. ... É [o projeto] utilizado, freqüentemente, para testar idéias ou para obter idéias sobre determinado assunto de interesse. ... Amostras por conveniência prestam -se muito bem aos objetivos da pesquisa exploratória, e não são recomendadas para pesquisas conclusivas". (MATTAR, 1997)

A definição do tamanho da amostra levou em consideração principalmente as condições do pesquisador, restringindo-se ànatureza não-probabilística e exploratória do estudo.

Assim, foram obtidos depoimentos de 21 pessoas, entre conselheiros e executivos, representando 10 organizações da sociedade civil. Nestes depoimentos foi possível analisar 46 incidentes críticos, com profundidades variáveis. Os respondentes foram definidos pelas próprias organizações.

Segundo Flanagan (op. cit.), o tamanho da amostra está intimamente relacionado ao número de incidentes críticos requeridos. Para determinar se incidentes adicionais são necessários de serem examinados, o autor sugere ser necessário contar o número de comportamentos críticos adicionados à classificação usada conforme se adicionam 100 incidentes. Para a maioria dos propósitos, segundo ele, uma cobertura adequada pode ser alcançada quando a adição de 100 incidentes críticos à amostra adiciona apenas dois ou três comportamentos críticos. Como parâmetro para amostras probabilísticas, o autor sugere ser necessário obter pelo menos três a quatro exemplos de cada comportamento crítico.

A escolha de uma amostra vinculada ao Programa Nossas Crianças foi baseada em três critérios: (a) a conveniência do pesquisador, (b) o reconhecimento público significativo do Projeto e (c) uma tentativa de garantir uma uniformidade mínima entre as organizações que permita a realização de análises exploratórias e inferências comparativas. Assim, o estudo englobou organizações similares em escopo e missão.

O Programa Nossas Crianças, desde a sua implantação em 1993, "mobiliza pessoas e empresas para a melhoria da vida de crianças e jovens". Consegue isto "através do sistema de adoção financeira e da implantação da Rede Nossas Crianças, que possibilita parcerias entre a sociedade civil mobilizada e entidades sociais". O Projeto seleciona entidades "de atendimento que executam Programas de Proteção e Socioeducativos na Região Metropolitana de São Paulo", utilizando critérios de competência e idoneidade. Uma equipe "de profissionais capacitados as acompanha para que os recursos sejam aplicados de maneira correta".

No Programa Nossas Crianças, a parceria com as entidades é realizada na forma de um convênio. É feito um repasse financeiro mensal "per capita", para atendimento em período integral (mais de 6 horas) ou para atendimento em período parcial (de 4 a 6 horas). O recurso "pode ser utilizado em custos diretos da criança, como recursos humanos, material escolar, alimentação, atividades recreativas, esportivas, culturais, profissionalizantes e bolsa-auxílio para adolescentes".

Para poderem paricipar da seleção para o convênio, as entidades devem contemplar as seguintes condições:

a) Localizar-se "na Região Metropolitana de São Paulo, parâmetro geográfico de proximidade imposto pela necessidade de manter um acompanhamento constante do trabalho de modo a assegurar a qualidade";

a) "Estar legalmente constituída e com atendimento sistemático há pelo menos 1 ano"; 
b) "Ter inscrição no CNPJ e registro no conselho Municipal dos Direitos da Criança e do Adolescente";

c) "Ser uma entidade não governamental que executa Programas de Proteção e Socioeducativos";

d) "Oferecer atendimento gratuito para crianças e jovens de famílias de baixa renda, em atendimento diário de no mínimo 4 horas";

e) "Ter o atendimento para crianças e adolescentes em situação de rua, creches, centros educacionais (CJ) e centros culturais, cursos profissionalizantes e adolescentes cumprindo medidas socioeducativas";

f) "Ter os atendimentos em conformidade com o ECA - Estatuto da Criança e do Adolescente";

g) "Ter estrutura física, equipamentos e capacidade técnica para garantir a manutenção do atendimento atual e para ampliação de vagas ou implantação de novo atendimento";

h) "Apresentar projeto para o atendimento e uma proposta de sustentabilidade do projeto após os 2 anos do financiamento."

Segundo a Fundação Abrinq, "a definição dos destinatários dos fundos conseguidos pelo Programa Nossas Crianças precisava levar em conta os objetivos iniciais: novos atendimentos para crianças e jovens até então desassistidos com um padrão mínimo de qualidade". Além das características acima, "foram estabelecidos pelo conselho, os seguintes critérios para repassar recursos a uma entidade candidata":

a) "A entidade não pode ser governamental e deve ter necessariamente condições de ampliar o número de atendimentos, sem entretanto fazê-lo às custas da sua qualidade, a qual deve ser preservada e, de preferência, elevada";

b) "O atendimento já oferecido na entidade deve ter caráter exemplar, com um padrão mínimo de qualidade nos serviços prestados";

c) "As instituições devem ser notoriamente idôneas e cadastradas no conselho Municipal da Criança e do Adolescente";

d) "O atendimento deve ser regular e sistemático, ou seja, com as mesmas crianças atendidas todos os dias, por no mínimo 4 horas, num projeto educativo estruturado, distinto do ensino regular de primeiro e segundo graus".

A Fundação Abrinq considera que "estes critérios para credenciamento de entidades com vistas ao Convênio que Ihes dá acesso às verbas do Programa Nossas Crianças seguem em pleno vigor e são ... recomendáveis como os mais adequados para operações assemelhadas".

As tabelas abaixo mostram os dados do Programa Nossas Crianças no segundo semestre de $2000^{3}$ :

${ }^{3}$ Fonte: 15o Relatório Semestral - Programa Nossas Crianças. Julho a Dezembro de 2000. 


\begin{tabular}{|cccc|}
\hline Mês/2000 & Crianças adotadas & $\begin{array}{c}\text { Crianças } \\
\text { beneficiadas }\end{array}$ & Valor de repasse \\
\hline \hline Julho & 2.410 & 25.821 & $\mathbf{R} \$ 169.350$ \\
Agosto & 2.515 & 26.669 & $\mathbf{R} \$ 176.850$ \\
Setembro & 2.480 & 26.669 & $\mathbf{R} \$ 180.967$ \\
Outubro & 2.546 & 27.748 & $\mathbf{R} \$ 184.432$ \\
Novembro & 2.546 & 27.748 & $\mathbf{R} \$ 184.432$ \\
Dezembro & 2.546 & 27.697 & $\mathbf{R} \$ 182.332$ \\
\hline
\end{tabular}

\begin{tabular}{|cc|}
\hline Mês/2000 & $\begin{array}{c}\text { Número de } \\
\text { Contribuintes }\end{array}$ \\
\hline \hline Julho & 1.253 \\
Agosto & 1.249 \\
Setembro & 1.253 \\
Outubro & 1.232 \\
Novembro & 1.237 \\
Dezembro & 1.237 \\
\hline
\end{tabular}

\begin{tabular}{|ccc|}
\hline Mês/2000 & $\begin{array}{c}\text { Entidades que recebem } \\
\text { recursos financeiros }\end{array}$ & $\begin{array}{c}\text { Entidades da Rede } \\
\text { Nossas Criancas }\end{array}$ \\
\hline \hline Julho & 40 & 72 \\
Agosto & 44 & 75 \\
Setembro & 44 & 75 \\
Outubro & 45 & 76 \\
Novembro & 45 & 76 \\
Dezembro & 45 & 76 \\
\hline
\end{tabular}

O Programa Nossas Crianças envolve atualmente cerca de 76 entidades e é considerado um exemplo de atuação profissional no campo da criança e do adolescente.

\subsubsection{INSTRUMENTAÇÃO}

Foram utilizados roteiros semi-estruturados para as entrevistas pessoais com os conselheiros e as lideranças executivas. Estes roteiros foram especificamente preparados para levantamento ds dados primários da pesquisa. As entrevistas foram gravadas (exceto uma), parcialmente transcritas e tiveram como finalidades: a) levantar eventos críticos vividos por conselhos; b) conhecer o comportamento exibido pelos conselhos das organizações da sociedade civil nestes eventos; e c) contribuir para a interpretação dos resultados alcançados na pesquisa.

Os roteiros foram desenvolvidos após consulta à literatura e a projeto semelhante desenvolvido nos Estados Unidos. Estes roteiros foram pré-testados antes de sua aplicação com os componentes da amostra. O préteste foi feito, formalmente, com 3 pessoas que têm contato regular profissional com conselhos de organizações sem fins lucrativos no Brasil e têm conhecimento e experiência em gestão.

O roteiro de entrevistas estava dividido em seis partes: 
- Contexto: para a coleta de informações a respeito do processo de construção da relação do entrevistado com a organização e levantar alguns dados institucionais e pessoais;

- Troca: para o levantamento de dados a respeito da relação e motivação do entrevistado em relação ao conselho;

- Incidentes críticos: visando conhecer casos reais de atuação do conselho de cada entidade;

- Liderança: buscando reunir descrições dos papéis e estilos de liderança exercidos no âmbito dos conselhos;

- $\quad$ Avaliação: consistia no questionário de avaliação do desempenho do conselho;

- Conclusão: para que o entrevistado pudesse agregar quaisquer outras informações ou comentários que julgasse pertinente.

As entrevistas permitiram identificar o comportamento dos conselhos das organizações da sociedade civil em incidentes considerados críticos por seus membros no decorrer da sua existência e vivenciados pelos próprios entrevistados. Tiveram duração aproximada de uma hora e meia em média, o que restringiu um pouco o aprofundamento em determinados incidentes.

Foram realizadas entrevistas separadas com o conselheiro e a liderança executiva das organizações da sociedade civil. Nestas entrevistas não houve preocupação com representatividade, mas em obter uma visão ampla e explorar pontos de vista diversos.

Durante as entrevistas, também foram feitas anotações para se poder escrever futuramente sobre o assunto. Tudo que foi dito era considerado confidencial. Cada organização é identificada como participante do projeto, mas todo o material usado no estudo será apresentado de uma forma que não permita a identificação de qualquer instituição ou pessoa.

As entrevistas estavam estruturadas em duas sessões: na primeira, conversava-se sobre alguns casos reais de atuação do conselho da organização; na segunda, o entrevistado era solicitado a responder um questionário de auto-avaliação do desempenho do conselho, baseado em perguntas de múltipla escolha.

O questionário foi desenvolvido a partir de um modelo proposto por Chait et allii $(1996)^{4}$, porém adaptado e desenvolvido com base na revisão de literatura e com base nas experiências anteriores do pesquisador. Ele estava dividido em 6 partes, diretamente relacionadas às 6 dimensões apresentadas por Chait et allii:

- Dimensão Analítica, levantando informações a respeito do processo de ponderação e discussão dos assuntos do conselho;

- Dimensão Contextual, buscando verificar como e quanto o conselho entende o contexto organizacional;

- $\quad$ Dimensão Educacional, avaliando a capacidade do conselho de se educar;

- Dimensão Estratégica, voltada a desvendar o processo de visualização e formatação institucional pelo conselho;

${ }^{4}$ CHAIT, R., HOLLAND, T.P. \& TAYLOR, B.E., Improving the performance of governing boards. The Oryx Press, Arizona, EUA, 1996. 
- Dimensão Interpessoal, identificando as principais ações do conselho relacionadas ao fortalecimento do trabalho em grupo;

- Dimensão Política, ligada àguarda da integridade do processo de governança pelo conselho.

Finalmente, foi feito um exame dos estatutos das organizações participantes, para verificar se as estruturas organizacionais adotadas estavam coerentes com as definições adotadas neste estudo, caracterizar o contexto legal da pesquisa e encontrar subsídios que enriquecessem o conteúdo das discussões. O exame dos estatutos deu-se no caso das 10 entidades que se dispuseram a responder às entrevistas e com outras 56 or ganizações cadastradas na Fundação Abrinq, participantes do Programa Nossas Crianças.

\subsubsection{MÉTOdOS DE ANÁLISE DE DADOS}

A análise dos dados é vista como um estágio de sumarização e descrição dos dados, de forma que estes possam ser usados para propósitos práticos. Busca-se, como sugerido por FLANAGAN (1954), o uso de um conceito referencial, a formulação de categorias e a determinação do nível adequado de generalidade e especificidade. A interpretação dos dados é entendida como uma fase de julgamento, onde procura-se deixar claro tanto as limitações enfrentadas, como o valor dos resultados encontrados.

Procurou-se caracterizar as principais práticas de operação dos conselhos de organizações da sociedade civil, num processo descritivo de análise.

"Métodos descritivos têm o objetivo de proporcionar informações sumariadas dos dados contidos no total de elementos das amostras estudadas. ... Compreendem: medidas de posição, medidas de dispersão e medidas de associação. As medidas de posição servem para caracterizar o que é 'típico' no grupo. As medidas de dispersão servem para medir como os indivíduos estão distribuídos no grupo. As medidas de associação servem para medir o nível de relacionamento existente entre duas ou mais variáveis". (MATTAR, 1997)

Como métodos descritivos de análise, procurou -se utilizar medidas de posição, como médias, e também medidas de dispersão, como distribuições de freqüências, ordenamento, amplitude, desvio padrão e coeficiente de variação.

Os dados são sistematizados e analisados àluz do que a literatura recomenda para uma eficaz atuação dos conselhos, utilizando, como referência central, o estudo das competências desenvolvido por CHAIT et allii (1993, 1996). 


\section{Primeira Parte: O Contexto Brasileiro}

\subsection{ReconheCEndo o Terceiro Setor}

Neste momento, toma-se consciência no Brasil da existência de um vasto setor apenas parcialmente conhecido, que há anos vem adquirindo maturidade $e$ experiência, atuando na execução de projetos e programas de interesse social, voltados para múltiplas realidades locais, mobilizando a participação popular, articulando-se com empresas privadas, comunidades locais, organismos internacionais e, em escala maior do que imaginado, com o próprio Estado. ${ }^{5}$

Afirmações como esta, extraída de uma dissertação de Mestrado produzida recentemente na Faculdade de Economia, Administração e Contabilidade da Universidade de São Paulo, mostram que o ponto de vista de que a sociedade pode ser organizada a partir de três setores está se consolidando. Mais do que simplesmente a adoção de um novo conceito, isso denota uma nova mentalidade, apoiada no reconhecimento da importância das iniciativas que surgem espontaneamente no seio da sociedade civil e de que o "modelo dualista" não é suficiente para oferecer respostas plenas aos dilemas sociais da atualidade. O recente episódio da revolta de presos em várias penitenciárias de São Paulo exemplifica um destes dilemas.

Dentre as características desta nova mentalidade pode-se destacar uma maior diferenciação entre o que é público e privado, e também entre o que é público estatal e o que é público não estatal (coletivo ou civil). Existe uma forte valorização da articulação entre diferentes instituições da sociedade para não só reclamar seus direitos, mas também construir melhores condições sociais, assumindo que os grandes problemas atuais do país e mesmo a construção de uma sociedade melhor só podem ser conquistados com o esforço de todos. E há uma preocupação em que todos os gastos (públicos ou privados) realizados na área social sejam mais efetivos. Tudo isso aparece incorporado em movimentos amplos como o da cidadania empresarial, da responsabilidade social de empresas, da reforma do Estado, da descentralização política e administrativa, das parcerias, da participação da sociedade civil na formulação das políticas públicas, da privatização e da publicização (incipiente que seja).

O terceiro setor no Brasil está deixando de ser uma denominação desconhecida e sendo encarado como um importante eixo do desenvolvimento do país, apesar de ser definido e conceituado de formas diversas por autores diferentes.

5 FALCONER, A.P. A Promessa do Terceiro Setor: um estudo sobre a construção do papel das organizações sem fins lucrativos e do seu campo de gestão. Dissertação de Mestrado, FEA-USP, São Paulo: 1999. 
Fernandes $(1994)^{6}$, cuja caracterização do terceiro setor é apresentada sinteticamente no quadro abaixo, reforça que sua função é atuar sobre problemas públicos, coexistindo com o setor público estatal e com o setor privado empresarial.

\begin{tabular}{|c|c|c|}
\hline Agentes & Fins & Setor \\
\hline Privados & Privados & Mercado \\
\hline Públicos & Públicos & Estado \\
\hline Privados & Públicos & Terceiro Setor \\
\hline Públicos & Privados & (corrupção) \\
\hline
\end{tabular}

Este conceito, segundo seu autor, denota uma qualificação importante: a de que o terceiro setor responde a necessidades coletivas, expandindo a idéia corrente sobre a esfera pública e presumindo que esta não se limita ao âmbito do Estado. Compõese de iniciativas de um universo bastante heterogêneo cuja influência depende do seu poder persuasão e cuja formação se dá por outras razões que não a busca do lucro inclusive porque o que fazem quase sempre é caro demais para os mercados disponíveis - dependendo, para sua subsistência, de doações voluntárias.

A noção de terceiro setor trazida por Fernandes, a partir de problemas públicos, deixa claro que a agenda das organizações que o compõem tem que ser seletiva, tamanha a diversidade de questões que ela abrange. A idéia do terceiro setor, diz o autor, não nos induz a imaginar a sociedade como um grande indivíduo coletivo, mas sublinha sua diversidade, limitando o uso de expressões como "o povo" ou "a nação". É um setor baseado em reações convergentes em torno de questões ou temas específicos que, apesar de tudo, deixam espaço para uma variedade de iniciativas autônomas e simultâneas. É um setor multicultural em que a coordenação é sobretudo um problema de comunicação e não de controle, que necessita de recursos de mediação para sua multiplicidade de linguagens e que freqüentemente evoca valores para o entendimento comum. É um setor em que convive-se com alianças múltiplas e parciais, sem deixar de ser verdadeiras, envolvendo parceiros diversos segundo as circunstâncias, e no qual confrontos e compromissos fazem parte de sua dinâmica interna.

Steve Waddell, citado por Falconer (1999, op. cit.), sintetiza um outro quadro de "tipos ideais", atribuindo características a cada um dos três setores:

\begin{tabular}{|l|c|c|c|}
\hline & Mercado & Sociedade Civil & Estado \\
\hline Interesse primário & Econômico & Social & Político \\
\hline Sistema de poder & Remunerativo & Normativo & Coercitivo \\
\hline Objetivos incluem & Criação de riqueza & Expressão de valores & Ordem social \\
\hline
\end{tabular}

${ }^{6}$ FERNANDES, R.C. Privado porém público: o terceiro setor na América Latina. Rio de Janeiro: RelumeDumará, 1994.

${ }^{7}$ Steve Waddell. "The advantages and challenges of na intersectoral development paradigm". Mimeo, 1998. 


\begin{tabular}{|l|c|c|c|}
\hline & Mercado & Sociedade Civil & Estado \\
\hline Competências incluem & $\begin{array}{c}\text { Produção de bens e } \\
\text { serviços }\end{array}$ & Mobilização comunitária & Imposição de padrões \\
\hline Recursos incluem & Capital financeiro & Energia voluntária & Lei/polícia \\
Deficiências incluem & Visão de longo prazo & Fragmentação & Rigidez \\
\hline
\end{tabular}

Salamon e Anheier (1997) $)^{8}$ ao procurarem definir o terceiro setor enfatizam a estrutura básica e a operação das organizações que o compõem. Segundo estes autores, o terceiro setor é composto por organizações que compartilham um conjunto de cinco características principais. São entidades:

Organizadas, isto é, institucionalizadas em algum grau. O que é importante é que a organização tenha alguma realidade institucional. ...

Privadas, isto é, insti tucionalmente separadas do governo. Organizações sem fins lucrativos não são nem parte do aparato governamental, nem controladas pelo governo ... Isto não significa que elas não possam receber apoio significativo do governo ou que nenhum representante do governo possa fazer parte da sua diretoria. A chave aqui é que organizações sem fins lucrativos precisam ser fundamentalmente instituições privadas na sua estrutura básica.

Não distribuidoras de lucros, isto é, não retornam quaisquer ganhos gerados a seus "proprietários" ou diretores. Organizações sem fins lucrativos podem acumular ganhos num ano qualquer, mas os ganhos precisam ser aplicados na missão da agência, não distribuídos aos "donos" da organização ou ao corpo dirigente. Neste sentido, organizações sem fins lucrativos são organizações privadas que não existem para gerar lucros. ...

Auto-governadas, isto é, aptas a controlar suas próprias atividades. Organizações sem fins lucrativos têm seus próprios procedimentos internos de governança e não são controladas por entidades externas.

Voluntárias, isto é, envolvendo um grau significativo de participação voluntária, seja na condução atual das atividades ou na gestão dos seus negócios. ... A presença de algum recurso voluntário, mesmo que apenas um conselho diretor voluntário, basta para qualificar uma organização como em certo sentido "voluntária".

Salamon (1992) ${ }^{9}$ atribui ainda uma sexta característica, num trabalho sobre o terceiro setor americano:

8 SALAMON, L.M. \& ANHEIER, H.K. Defining the Nonprofit Sector - A cross-national analysis. Johns Hopkins Nonprofit Sector Series, Manchester University Press, New York: 1997.

${ }^{9}$ SALAMON, L.M.. America's Nonprofit Sector: a primer. Nova York: The foundation Center, 1992. 
De benefício público, isto é, elas servem a algum propósito público e contribuem para o bem público.

Caracterizar o terceiro setor no Brasil orientando-se por estes quadros permite perceber sua enorme heterogeneidade, com grande número de organizações: entidades religiosas que oferecem serviços assistenciais; entidades associativas industriais e comerciais; sindicatos; clubes esportivos e culturais; universidades e hospitais privados; fundações empresariais e familiares; entidades comunitárias; ONGs diversas. Para denominá-las, Falconer $(1999)^{10}$ afirma que o termo "organização da sociedade civil é uma crescente designação popular para todo um conjunto de organizações sem fins lucrativos", trazendo consigo a "idéia positiva de cidadania, de diversidade da sociedade ao invés de um setor unificado", ao mesmo tempo que inclui "organizações que não são parte do estado, nem são empreendimentos comerciais, lucrativos". O tamanho do terceiro setor formal no Brasil é de pelo menos 220.000 organizações:

\section{Pode-se afirmar que o Brasil conta com um dos maiores terceiros setores do} mundo em termos absolutos e uma posição de liderança entre os países em desenvolvimento quanto àsua participação no nível de emprego. (Falconer, 1999)

O reconhecimento do terceiro setor é possível de ser notado concretamente em diferentes instâncias:

- na mídia, que está dedicando cada vez mais espaço em jornais e revistas (por exemplo, hoje, em média duas entre cada cinco páginas que a Mídia Jovem dedica a matérias jornalísticas são ocupadas por assuntos que contribuem para a formação cidadã de seu público, segundo a ANDI);

- no governo, que vem priorizando o estabelecimento de parcerias com organizações privadas que não visam lucro e fomentando o crescimento de iniciativas não formais de trabalho social (por exemplo, o Programa Voluntários do Comunidade Solidária já conta com mais de 20 centros espalhados pelo país);

- pelas empresas e empresários, que vêm se mostrando mais preocupados em participar e apoiar empr eendimentos voltados para o bem da comunidade em geral e sua valorização.

Esse notável crescimento do terceiro setor, que se destacou a partir dos anos 80 , tem sido significativo do ponto de vista quantitativo. Do ponto de vista qualitativo, entretanto, o quadro é duvidoso. Apesar de haver várias organizações dos mais diversos tipos realizando trabalhos excepci onais, inclusive recebendo prêmios e chancelas internacionais, a maioria das organizações do terceiro setor no Brasil ainda está iniciando um processo de profissionalização.

Falconer (op. cit.) expressa isso da seguinte forma:

Ouve-se, simultaneamente ao discurso que idealiza o setor, que estas entidades são mal geridas, excessivamente dependentes, amadoras e assistencialistas em

${ }^{10}$ FALCONER, A. Repensando o Público na América Latina: As Organizações da Sociedade Civil. International Society for Third Sector Research - ISTR, Primeiro Encontro da Rede de Pesquisa do Terceiro Setor da América Latina e Caribe. In: RITS, www.rits.org.br, 1999. 
sua atuação e, por vezes, sujeitas a motivações pouco filantrópicas, para não dizer criminosas.

No International Forum on Capacity Building, promovido pela Associação Brasileira das Organizações Não Governamentais - ABONG - realizado entre os dias 19 e 22 de novembro de 2000, no Rio de Janeiro, do qual participaram associações nacionais de ONGs da América Latina, bem como agências bi e multilaterais, essa preocupação também veio à tona. Segundo o presidente da ABONG, Silvio Caccia Bava ${ }^{11}$, tratava-se de um fórum criado em 1998, em Bruxelas, cujo maior objetivo é fortalecer a capacidade institucional das ONGs do hemisfério sul. Naquela reunião concluiurse que:

O fortalecimento institucional das ONGs interessa como uma forma de estimular que essas instituições atuem como agentes de transformação social, que se integrem aos movimentos cidadãos da sociedade civil e reforcem o processo de mudança social na América Latina, tendo como foco a redução da desigualdade e a inclusão social. Dessa forma, não se trata apenas da visão de uma gestão mais eficaz, embora isto também seja necessário. O fortalecimento institucional deve ser um meio para reforçar a capacidade das ONGs cumprirem as suas missões, as suas estratégias, os seus objetivos.

Para estimular que isto aconteça, o Forum estabeleceu quatro eixos fundamentais:

Desenvolvimento de uma maior capacidade de dar visibilidade ao trabalho das ONGs e estabelecer uma melhor comunicação com a sociedade como um todo;

Geração de conhecimento;

Estabelecimento de parceria com outras instituições da sociedade civil através de redes e fóruns;

Desenvolvimento organizacional.

Ainda de acordo com Caccia Bava:

Quando falamos em desenvolvimento organizacional de nossas instituições, aí sim é uma questão de melhorar a capacidade de gerir, captar recursos, desenvolver indicadores que possam prestar contas à sociedade sobre os resultados de nosso trabalho. Porém, é bom que se diga que esses instrumentos de gestão são uma preocupação para melhorar a nossa capacidade de realizar os três pontos anteriores.

Instituições acadêmicas importantes no Brasil, como USP, FGV e PUC têm procurado responder a essa situação, sobretudo através de programas de pesquisa, centros de estudos e formação específica. Algumas destas iniciativas encontram-se funcionando há mais de cinco anos (LANDIM e VILHENA, 1998 ${ }^{12}$ ). Além disso, uma série de prêmios vêm sido oferecidos numa tentativa de reconhecer e disseminar iniciativas

\footnotetext{
${ }^{11}$ Fonte: RETS - Revista Eletrônica do Terceiro Setor - www.rets.org.br - 28 de novembro de 2000.

${ }^{12}$ LANDIM, L. e VILHENA, L.R., O Terceiro Setor no Brasil, mimeografado, julho de 1998.
} 
pautadas pela qualidade, como o Prêmio Bem Eficiente, o Prêmio Criança e o Prêmio Empreendedor Social, entre outros.

Apesar do grande interesse (e investimentos) em pesquisa, formação e disseminação mostrado tanto por instituições acadêmicas como por fundações e serviços de aprendizagem, é preciso reconhecer que o desenvolvimento de conhecimentos específicos para este setor é bastante recente. Há que se tomar o devido cuidado para não cair na tentação de simplesmente transferir literalmente conceitos aplicáveis a organizações empresariais e públicas para organizações do terceiro setor.

Paralelamente, um grande risco é se alimentar uma ilusão quanto ao papel "salvador da pátria" do terceiro setor. Falconer (op. cit.) alerta sobre a existência de um abismo entre aquilo que se espera que o setor faça e aquilo que ele realmente é capaz de fazer. Ele defende que:

... expectativas irrealistas sobre o papel do terceiro setor ... são tão responsáveis pelas aparentes deficiências do terceiro setor no Brasil quanto a falta de competência em gestão organizacional. ... Propõe se que o tipo de competência de gestão que o terceiro setor requer deve atender àespecificidade destas expectativas e papéis; particularmente, a necessidadede conciliar o plano organizacional, das entidades sem fins lucrativos, àdimensão de políticas públicas e dos desafios públicos que o terceiro setor espera enfrentar.

Como manifestação desta preocupação em desenvolver conhecimentos alinhados com as caract erísticas específicas do terceiro setor, em 1986 uma organização americana chamada Independent Sector realizou uma pesquisa nacional nos Estados Unidos para identificar atributos comuns que os melhores grupos sem fins lucrativos exibiam. Segundo os autores do estudo ${ }^{13}$, o projeto consistiu em quatro partes: a) um extenso exame de mais de 200 estudos e referências sobre eficácia organizacional; b) um grupo focal com 20 líderes e consultores do setor sem fins lucrativos; c) um questionário levantando a visão de mais de novecentos diretores executivos e presidentes de conselho; d) perfis aprofundados de dez grupos sem fins lucrativos que um painel de fundações comunitárias julgou serem especialmente eficazes. Este projeto concentrou-se em grupos com abrangência local e procurou não incluir congregações religiosas, universidades e hospitais, chegando a quatro características que diferenciam as ótimas sem fins lucrativos das meramente boas:

Um senso de missão claramente articulado, que serve como ponto focal de comprometimento para conselho e equipe executiva e que é a referência pela qual a organização julga seu sucesso e faz ajustes de percurso no decorrer do tempo; Um indivíduo que realmente lidera a organização e cria uma cultura que possibilita e motiva a organização a cumprir sua missão;

${ }^{13}$ KNAUFT, E.B., BERGER, R.A. \& GRAY, S.T. Profiles of excellence: achieving success in the nonprofit sector. Jossey Bass Inc. Publishers, San Francisco, EUA: 1991. 
Um conselho voluntário envolvido e comprometido que relaciona-se

dinamicamente com o principal executivo e provê uma ligação com a comunidade

maior;

Uma permanente capacidade de atrair suficientes recursos financeiros e humanos.

Este conjunto de qualidades têm uma relação bastante forte com a ciência da Administração, permitindo afirmar que conceitos, técnicas e práticas advindas deste campo podem de fato aprimorar a forma como as organizações atuam dentro do setor, como já se vê em alguns casos. Falconer ressalta isso da seguinte forma:

A idéia de que a eficiência e a eficácia de resultados constituem o principal desafio das organizações da sociedade civil é fundamentalmente diferente do que se via em um passado recente, quando a mera existência de uma organização ou a validade da causa defendida por esta seriam apontados, freqüentemente, como suficientes para justificar uma doação de recursos a fundo perdido ... Agora, na discussão sobre os fins das organizações, a Administração adquire maior importância com adoção do discurso empresarial de resultados. Esta não é uma mudança cultural completa, mas manifestação visível de um processo gradual de transformação pela qual vêm passando os atores organizacionais do campo do desenvolvimento social em todo o mundo...

A busca de qualidade na atuação das entidades do terceiro setor não tem, porém, somente um caráter técnico ou gerencial. Ela influencia decisivamente sua legitimidade perante a sociedade e os outros setores, no sentido de ser capaz de agir com competência e eficácia na prestação de serviços e no preenchimento do papel público que Ihes é atribuído. O alerta de Falconer (op. cit.) precisa ser considerado:

As Ciências de Gestão enfocam o nível das organizações, mas é imperativo recordar que atingir a eficiência em organizações individuais e independentes não é necessariamente o melhor caminho para solucionar problemas públicos: 0 interesse de organizações não eqüivale, necessariamente, ao interesse do setor, nem tampouco ao interesse público. ...

No plano organizacional, o principal desafio consiste em alcançar a eficiência, a eficácia e, na maioria dos casos, a perpetuidade organizacional. Na perspectiva setorial, o crescimento e a consolidação do terceiro setor frente ao Estado eao Mercado pode ser o principal objetivo. Já em uma visão ampla de políticas públicas, o objetivo central deve ser a resolução de problemas públicos... ...

Desenvolver um campo de gestão do terceiro setor sensível a estas questões é imperativo para evitar a perda, nem bem conquistada, da identidade deste setor. ... A perspectiva de problemas públicos e políticas públicas deve estar na mente do administrador do terceiro setor, tanto quanto os problemas imediatos de sobrevivência de suas organizações. 
Com base no seu raciocínio, Falconer (op. cit.) indica quatro grandes áreas onde há necessidade de desenvolvimento de gestão que podem ser generalizadas para o terceiro setor como um todo:

Stakeholder accountability: refere-se ànecessidade de transparência e ao cumprimento da responsabilidade da organização de prestar contas perante os diversos públicos que têm interesses legítimos diante delas; ...

Sustentabilidade: ... entendida aqui como a capacidade de captar recursos ... de maneira suficiente e continuada, e utilizá-los com competência, de maneira a perpetuar a organização e permiti-la alcançar os seus objetivos; ...

Qualidade de serviços: ... o aprimoramento da qualidade deve ser um objetivo contínuo das entidades, que não podem se acomodar em uma postura de satisfação de estar fazendo a sua pequena parte, ou de paralisia frente ao sentimento de impotência diante da magnitude dos déficits sociais; ...

Capacidade de articulação: as organizações do terceiro setor não poderão mais atuar de forma isolada se pretenderem abordar de forma séria os complexos problemas sociais para os quais são geralmente criadas. O paradigma do século $X X$ segundo o qual problemas são melhor enfrentados por organizações formais é, aos poucos, substituído por um modelo que enfoca a necessidade de articulação de redes. Em lugar de privilegiar o espaço organizacional, olha para as relações: entre indivíduos, grupos, organizações, setores.

Em síntese, os desafios que se colocam às organizações que compõem o setor sem fins lucrativos estão relacionados tanto ao seu desenvolvimento institucional, especialmente na área da gestão, como também ao fortalecimento de seu papel na sociedade atual. Um desenvolvimento puramente gerencial pode ser a solução para uma ou mais organizações específicas, mas parece não ser suficiente para o setor como um todo. É preciso que as organizações fortaleçam-se não isoladamente, mas em conjunto, possivelmente a partir de esforços articulados, orientados por questões específicas, voltados para a resolução de problemas públicos. O fortalecimento das organizações da sociedade civil envolvendo sua significância na resolução de problemas públicos e sua legitimação perante a sociedade depende não somente do seu gerenciamento eficaz, mas também da sua inserção coletiva e articulação política (no melhor e mais puro sentido).

No ponto de vista deste pesquisador, este desafio exige o aprimoramento das formas e práticas de governança institucional.

Para isso não é simplesmente o caso de capacitar técnicos e administradores, mas de desenvolver lideranças. Não basta melhorar a qualidade dos serviços, é necessário aprimorar e integrar estratégias. Não é o caso somente de definir e atender determinados públicos alvo, mas de "empoderá -los" e "incluí-los" nos processos. Não adianta apenas fazer parte de uma rede, mas nutrir conscientemente essa forma de atuação. Exigese ampliar o alcance de cada instituição e do conjunto delas, envolvendo a dimensão temporal (o foco em ações duradouras e de longo alcance), a dimensão política (o desenvolvimento de relações sinérgicas e de mão dupla), a dimensão social (a solução de problemas que sobrepujam a capacidade organizacional) e a dimensão ética (o desenho de processos que refletem os valores morais de uma sociedade democrática). 
O senso comum sugere que a maioria das pessoas está familiarizada com os mecanismos de governança que garantem (bem ou mal) a integridade e direcionamento das iniciativas governamentais e empresariais, em diferentes níveis. No âmbito governamental pode-se citar: o congres so nacional, o senado federal, as assembléias legislativas, os tribunais de contas, os conselhos nacionais, estaduais e municipais das diferentes áreas, os diferentes conselhos intra-institucionais e os próprios eleitores. Na esfera empresarial podese ciar os conselhos regionais, as confederações e associações setoriais, os conselhos de administração, os órgãos de regulação estatal, as associações de classes, os serviços de proteção ao consumidor, os concorrentes e os consumidores. Ambos os setores (e o erceiro setor) estão ainda sob escrutínio permanente da mídia e de grupos organizados da sociedade civil.

O terceiro setor também conta com mecanismos de governança para "proteger-se" contra fraudes, corrupção e desvirtuamento, embora tenha-se menor clareza a respeito. Os principais são:

- Conselhos e diretorias: quase todas as organizações sem fins lucrativos são (mal ou bem) dirigidas por um grupo de voluntários que é legalmente responsável por assegurar que a entidade se mantenha fiel à sua missão, proteger seu patrimônio e operar em benefício público. Os conselhos (e/ou diretorias) constituem, pelo menos em tese, a primeira linha de defesa contra abusos e desvios.

- Ministério Público: principalmente no caso das fundações, o ministério público é responsável por verificar se a organização está contribuindo para os seus objetivos primordiais.

- Órgãos de regulação estatal: entre eles estão os conselhos municipais, as secretarias de ação social e a secretaria da fazenda.

- Outras organizações da sociedade civil: várias organizações deste tipo existem não para monitorar o desempenho de suas colegas, mas para orientá-las e capacitá-las a bem exercer sua função. Podemos citar como exemplos o GIFE - Grupo de Institutos, Fundações e Empresas, a ABONG - Associação Brasileira de Organizações Não-Governamentais, o ISER - Instituto de Estudos da Religião, entre outras. Além disso, muitas organizações atuam fomentando o trabalho de suas parceiras.

Em última instância, qualquer associado ou cidadão pode exercer um papel ativo a favor de uma atuação íntegra de uma organização da sociedade civil.

Os relatos a seguir dão idéia genérica de como são as formas de governança das organizações da sociedade civil atualmente...

Numa pesquisa realizada em 1994 com 145 organizações pertencentes à ABONG e espalhadas por todas as regiões do país, Landim ${ }^{14}$ perguntou por atividades, conformação institucional, orçamento, fontes de recursos, funções, funcionários e outras informações. Cerca de 95\% das ONGs estudadas eram registradas como associações civis sem fins lucrativos, sendo apenas 5 as fundações. Neste universo, 19,3\% possuíam registro no conselho Nacional da Assistência Social, 9,7\% tinham o registro de Utilidade Pública Federal, 24\% a Utilidade Pública Estadual e 31,7\% a Utilidade Pública Municipal, denotando um reconhecimento social mais localizado. Em termos de âmbito de atuação, a pesquisa constatou, entretanto, que $47 \%$ delas atuava em nível estadual, 38\% em nível municipal e 29\% em nível local. $44,5 \%$ das ONGs tinha um

${ }^{14}$ LANDIM, L. Ações em sociedade: militância, caridade, assistência, etc. Rio de Janeiro: NAU, 1998. 
orçamento igual ou inferior a US $\$ 100.000$ e $43,7 \%$ entre US $\$ 100.000$ e US $\$ 500.000$, havendo uma média de 23 pessoas envolvidas em suas atividades, entre funcionários e voluntários (mas 67,6\% das entidades possuía menos de 10 funcionários contratados). Os postos de direção eram ocupados por 588 diretores, sendo 33\% deles mulheres. Das 145 entidades, 70,3\% declarou ter associados.

Novaes $(1998)^{15}$, falando das iniciativas vicentinas, diz que a Sociedade S. Vicente de Paula está presente em 123 países (no Brasil há 121 anos) e que a lógica da organização é o desmembramento constante em conferências. Cada conferência deve ter, no máximo, 15 membros; 10 conferências formam um Conselho Particular; 12 Conselhos Particulares compõem um Conselho Central; para 15 Conselhos Centrais, um Conselho Metropolitano. O movimento era estimado em algo em torno de 300.000 membros constantes, organizados em 23 conselhos Metropolitanos, 20.000 postos de atendimento e 3.000 obras sociais em todos os estados brasileiros, movendo-se grandemente em virtude do tabalho voluntário. Novaes conta ainda:

No que diz respeito aos mecanismos utilizados para manter a unidade, vitalidade $e$ reprodução de sua Sociedade, os vicentinos buscam divulgar e atualizar a "metodologia da caridade" (através da sindicância, ajuda e controle sobre as famílias assistidas) e incentivar o ingresso de jovens em suas Conferências.

Sobre as iniciativas espíritas, Giumbelli $(1998)^{16}$ informa que, do ponto de vista organizacional, o centro espírita é uma espécie de unidade elementar, possuindo personalidade jurídica e sendo mantido por um grupo de adeptos que se dividem entre as tarefas de administração e atividades religiosas. Existem várias federações e uniões espíritas, para desempenhar dois papéis em relação às demais organizações espíritas: normatização doutrinária e representação institucional. Utilizam para isso mecanismos diversos como publicações, orientação e instâncias representativas, procurando assegurar legitimidade às suas entidades para atuarem como porta-vozes das demais instituições. Giumbelli afirma:

É nesse sentido que se pode considerar as federações enquanto mediadoras entre o universo institucional do Espiritismo e a sociedade mais ampla. Única entidade federativa em âmbito nacional, a Federação Espírita Brasileira (FEB) ... destaca-se como a principal instituição do Espiritismo brasileiro. Criada em 1884, ela passou a ter um papel decisivo em termos do congraçamento de instituições espíritas em todo o território nacional...

Destaque é dado ao conselho da Federação, que conta œm representantes das federações estaduais, reunindo-se anualmente para traçar as diretrizes de atuação para a entidade.

No universo espírita do Rio de Janeiro, com 864 instituições existentes, apenas 51,5\% estão filiadas a uma grande federação estadual. Giumbelli justifica:

${ }^{15}$ NOVAES, R.R. Juventude e ação social católica no rio de Janeiro: resultados de pesquisa. In: LANDIM, L. Ações em sociedade: militância, caridade, assistência, etc. Rio de Janeiro: NAU, 1998.

${ }^{16}$ GIUMBeLLI, E. Caridade, Assistência Social, Política e Cidadania: Práticas e Reflexões no Espiritismo. In: LANDIM, L. Ações em sociedade: militância, caridade, assistência, etc. Rio de Janeiro: NAU, 1998. 
Uma boa parte dos centros, entidades filantrópicas e outros tipos de instituições espíritas preferem não estar vinculados a nenhuma federação. E, de fato, não há nenhuma obrigatoriedade quanto a isso, o que confere ao universo espírita uma peculiar fragmentação organizativa e justifica um discurso baseado na idéia de autonomia institucional, assumido pelas próprias federações. ... Além disso, em boa parte dos lugares encontramos o que se pode chamar de estruturas paralelas de normatização e representação: duas ou mais federações estaduais no mesmo estado, duas ou mais federações municipais no mesmo município.

Considerando informações concedidas por órgãos do Executivo ligados à pasta da Justiça, Giumbelli informa que $45 \%$ dos centros espritas e pelo menos $76 \%$ das obras sociais foram reconhecidas de utilidade pública em algum âmbito governamental. No caso das obras sociais, pelo menos $37 \%$ obteve o certificado de entidade filantrópica expedido pelo conselho Nacional de Assistência Social- CNAS.

Giumbelli, a respeito da dinâmica da interação atual do movimento espírita com a sociedade, traça ainda uma conclusão significativa, ligada ao fenômeno da governança:

Pode-se afirmar ... que o Espiritismo é atualmente atravessado por dinâmicas de duas naturezas. De um lado, as demandas surgidas da constituição de novos mecanismos de relacionamento entre Estado e sociedade civil- caso dos conselhos de direitos - tanto mais prementes quanto maior o envolvimento efetivo de instituições e lideranças espíritas. De outro, o desenvolvimento de questionamentos e reflexões por algumas dessas lideranças, que passam por temas como política e cidadania, e que são concomitantes àparticipação dos espíritas em mobilizações como a Campanha da Fome. De um ponto de vista mais geral, essas duas dinâmicas são as responsáveis pelas mais relevantes transformações nas formas pelas quais os espíritas desenvolverão suas atividades de assistência social e pode-se prever que sua conjugação terá papel fundamental na atualizaçãoda inserção do Espiritismo, com suas lideranças e instituições, em um espaço público.

Uma iniciativa bastante conhecida na sociedade brasileira é a Campanha contra a Fome, liderada por Herbert de Souza e a Ação da Cidadania. Landim (op. cit.) relata que es sa Campanha possuiu suas instâncias próprias de organização ou de convocação, destacando-se: uma Secretaria Executiva Nacional, o IBASE, a mídia, o Comitê Idéias, os artistas, o Comitê das Estatais, a Igreja e grupos religiosos (o Fundo Inter-Religioso con tra a Miséria e pela Vida), os comitês e o Comitê Rio. Os Comitês Estaduais criaram-se formalmente e constituíram-se em um dos espaços de centralização de informações em cada região, tendo sua composição extremamente variada.

O Comitê Rio, considerado um pólo importante da campanha, tinha uma coordenação composta de grandes instituições ou de entidades associativas representativas de segmentos sociais. Landim avalia que a idéia de um comitê representativo da sociedade norteava sua forma de organização, a qual se completava com uma subdivisão interna em comissões. Entretanto, essa coordenação ficou esvaziada conforme aumentava a amplitude, o volume e a intensidade dos acontecimentos, de maneira que o Comitê Rio acabou por funcionar a partir do trabalho de umgrupo de responsáveis que nada representavam. 
Coelho $(2000)^{17}$ realizou uma pesquisa de doutoramento cujo objetivo foi contribuir para o conhecimento do terceiro setor, que engloba organizações sem fins lucrativos. Ela efetuou uma pesquisa com 74 entidades brasileiras dos mais diferentes tipos, ligadas à educação infantil na região metropolitana de São Paulo, extraídas de um universo de 438 entidades cadastradas na Secretaria da Criança, Família e Bem-Estar Social em 1994. Também recolheu material produzido pela ABONG e pelo Iser, bem como visitou e entrevistou dirigentes de 20 entidades americanas localizadas na cidade de Pittsburgh (EUA), como parâmetro de comparação - segundo ela, Pittsburgh é uma das cidades americanas onde o terceiro setor mais se estruturou e solidificou. Suas análises relacionaram-se: às condições operacionais de funcionamento, suas características de origem, seu perfil institucional, sua estrutura interna de funcionamento, o tipo de mão de obra empregado e seus recursos físicos e instal ações.

Entre as principais informações obtidas naquela pesquisa, destacam -se:

- No Brasil, as organizações são relativamente pequenas e adotam uma estrutura de funcionamento informal, baseada em algumas funções -chave: direção, coordenação geral, coordenação técnica de programas e serviços de apoio administrativo. A existência do estatuto é pro forma, apenas o cumprimento de uma exigência legal, sendo que os conselhos diretivos existem e funcionam, embora de forma esporádica. A organização administrativa é, via de regra, centrada na diretoria, especialmente na figura do diretor, elo de ligação para todos os assuntos; ele administra a instituição e decide questões administrativas e pedagógicas. Não há a rigor uma estrutura formal para os demais níveis organizacionais, que acabam funcionando porque certas pessoas se responsabilizam por tarefas que não são determinadas a pirori, mas surgem de acordo com o desenvolvimento das atividades da organização.

- As organizações operam com um quadro de pessoal bastante enxuto, muitas vezes até insuficiente. A maior parte dos profissionais dedica-se ao atendimento direto à criança, havendo um grande grau de improvisação diante das necessidades administrativas. Observa-se alta rotatividade em função dos baixos salários e das condições precárias de trabalho. Verificou-se que a menor receita mensal destas entidades é de $R \$ 1.728,51$ e a maior, de $R \$ 489.222,00$, sendo que $50 \%$ das organizações sustentam se com uma receita inferior a $\mathrm{R} \$ 38.643,79$; a maioria destas organizações utiliza verbas públicas.

- Os voluntários constituem 19\% do total de pessoal (contra 29,2\% nas americanas), a maioria concentrando-se na direção geral (64,4\%): grande parte deles atua junto aos conselhos diretivos e é proibida legalmente de receber remuneração. Em geral, os voluntários brasileiros são profissionais qualificados, sendo dentistas, psicólogos e médicos os mais utilizados pelas organizações; nas organizações americanas as categorias profissionais mais procuradas estão na área administrativa (administradores e advogados). No Brasil, o recrutamento e a seleção "se dá com critérios mais frouxos: procura-se averiguar basicamente a disponibilidade da pessoa e sua experiência profissional", enquanto nos EUA as entrevistas são minuciosas e o desempenho anterior como voluntário é investigado.

${ }^{17}$ COELHO, S. C. T.. Terceiro Setor: um estudo comparativo entre Brasil e Estados Unidos. São Paulo: Editora SENAC São Paulo, 2000. 
Estas descrições dão uma pequena idéia de como as organizações da sociedade civil são governadas, bem como da sua diversidade. Muito pouca atenção acadêmica tem sido dada ao assunto, refletindo-se no reduzido número de artigos e publicações a respeito.

Sendo as organizações do terceiro setor "autogovernadas", possuindo um forte caráter autônomo e com seus próprios procedimentos internos de controle das atividades, pode-se esperar que o conselho e/ou a diretoria, formados por volu ntários, tenham significativa influência direta na governança das organizações da sociedade civil.

Este estudo pretende deixar explícita a importância potencial dos conselhos diretores nas organizações da sociedade civil. No Brasil, começa-se a valorizar o tema, tanto que o assunto é incluído na lista de critérios para o Prêmio "Bem Eficiente".

É sobre a governança das organizações da sociedade civil, o desempenho dos seus conselhos e sua relação com o desempenho das organizações, especificamente aquelas vinculadas ao Programa Nossas Crianças, que se desenvolve esta Dissertação de Mestrado.

\subsection{Marco legal bRASILEIRO}

Para o entendimento dos sistemas de governança e do papel dos conselhos e diretorias, é importante considerar o sistema legal em que se inserem. No Brasil, à medida que o terceiro setor vem se firmando, vão sendo propostas novas leis para sustentar o seu desenvolvimento. Uma parte delas relacionase às questões de governança, como pode ser visto a seguir.

\subsubsection{LEGISLAÇÃO GERAL}

Tradicionalmente, as organizações que funcionam no terceiro setor são pessoas jurídicas de direito privado sem fins lucrativos. Em sua disposição mais genérica a respeito do sistema de governança destas instituições, o Código Civil Brasileiro ${ }^{18}$ dispõe que:

Art. 16. São pessoas jurídicas de direito privado :

I- As sociedades civis, religiosas, pias, morais, científicas ou literárias, as associações de utilidade pública e as fundações.

II-As sociedades mercantis.

Art. 17. As pessoas jurídicas serão representadas, ativa e passivamente, nos atos judiciais e extrajudiciais, por quem os respectivos estatutos designarem, ou, não o designando, pelos seus diretores.

As pessoas jurídicas de direito privado podem ser de três tipos: sociedades, associações e fundações. Paes $(1999)^{19}$ informa que enquanto nas associações e sociedades predomina o elemento pessoal (agrupamento

\footnotetext{
${ }^{18}$ VIEIRA NETO, M.A. (org.) Código Civil Brasileiro. São Paulo: Saraiva, 1984.

*A lei 9.096/95, por meio do artigo 59, acresceu, às pessoas jurídicas de direito privado, os partidos políticos.
} 
de pessoas físicas), nas fundações a pessoa jurídica se organiza em torno de um patrimônio destinado à consecução dos fins comuns - as pessoas se reúnem para colocarem em atividade aquele patrimônio. Outra diferença é que as associações e sociedades têm sua criação materializada na ata que aprova os estatutos e indica seus dirigentes, enquanto as fundações dependem da manifestação da vontade de um instituidor, via escritura pública ou testamento.

O Código Civil prevê que, para existirem legalmente, as pessoas jurídicas de direito privado devem ser registradas em cartório, através de seus estatutos, atos constitutivos ou contratos. Neles devem estar expressos os fins da organização, o modo pelo qual ela é administrada e a responsabilidade dos membros.

Os órgãos de uma associação variam conforme o que dispuser o estatuto, mas, comumente, são a assembléia geral ou um conselho deliberativo e a diretoria.

(PAES, 1999)

Para caracterizar a condição de organização sem fins lucrativos, o Código Civil estabelece também, no Artigo 22, o seguinte:

Extinguindo-se uma associação de intuitos não econômicos, cujos estatutos não disponham quanto ao destino ulterior dos seus bens, e não tendo os sócios adotado a tal respeito deliberação eficaz, devolver-se-á o patrimônio social a um estabelecimento municipal, estadual ou federal, de fins idênticos ou semelhantes.

Este dispositivo reflete o pressuposto de que uma organização deste tipo tem a posse do patrimônio somente nas mãos de pessoas jurídicas; parte também do pressuposto que a apropriação do patrimônio por pessoas físicas caracterizaria distribuição de lucros ou resultados.

Landim $(1997)^{20}$ esclarece que o caráter sem fins lucrativos é assegurado ao incluir-se no estatuto cláusulas especificando quais serviços a organização prestará à comunidade e que não faz distinção de credo, raça, cor ou convicção política; também é necessário explicitar que qualquer superávit ou lucro deve ser totalmente aplicado nas finalidades definidas em estatuto.

Além disso, organizações sem fins lucrativos não podem remunerar seus dirigentes (em quaisquer formas) para ter direito àisenção do Imposto de Renda e ao título de utilidade pública.

É característica presente na grande maioria - ou quase unanimidade - das entidades de interesse social ... a inexistência do pagamento de remuneração aos integrantes de seus órgãos de administração, conselheiros ou diretores. (PAES, 1999)

${ }^{19}$ PAES, J.E.S. Fundações e entidades de interesse social - aspectos jurídicos, administrativos, contábeis e tributários. Brasília: Brasília Jurídica, 1999.

${ }^{20}$ LANDIM, L. Brazil. In: SALAMON, L. \& ANHEIER, H. Defining the nonprofit sector: a cross-national analysis. New York: Manchester University Press, 1997. 
Advogados e contadores costumam utilizar, como marco legal que regula, genericamente, as organizações sem fins lucrativos, a lei das sociedades anônimas ${ }^{21}$, pelo seu alto nível detalhamento e especificação (recurso de interpretação analógica). Os principais itens desta lei que afetam o terceiro setor são, resumidamente:

- A administração da organização compete, conforme dispuser o estatuto, ao conselho de administração e àdiretoria, ou somente àdiretoria;

- O conselho de administração é órgão de deliberação colegiada, sendo composto por no mínimo três membros eleitos pela assembléia geral;

- Compete ao conselho de administração fixar a orientação geral das atividades da organização e fiscalizar sua gestão (entre outras);

- A diretoria deve ser composta por dois ou mais diretores, eleitos pelo conselho ou pela assembléia geral - membros do conselho podem ser eleitos para até 1/3 dos cargos de diretores;

- De maneira geral, aos diretores compete a representação da entidade e a prática dos atos necessários para seu funcionamento regular;

- Dever de diligência - o adm inistrador da companhia deve empregar, no exercício das suas funções, o cuidado e diligência que todo homem ativo e probo costuma empregar na administração de seus próprios negócios;

- Dever de lealdade - o administrador deve servir com lealdade à companhia e manter reserva sobre os seus negócios, sendo vedado valer-se de informações para obter vantagens para si ou para outrem;

- Dever de informar - o administrador é obrigado a revelar à assembléia geral ordinária quaisquer atos ou fatos relevantes nas atividades da companhia;

- Estas normas se aplicam aos membros de quaisquer outros órgãos, criados pelo estatuto, com funções técnicas ou destinados a aconselhar os administradores;

- Deve haver um conselho fiscal permanente, composto por no mínimo três e no máximo cinco membros e igual número de suplentes, eleito pela assembléia geral, cujo estatuto dispõe sobre seu funcionamento;

- A função de membro do conselho fiscal é indelegável;

- Compete ao conselho fiscal fiscalizar os atos dos administradores, examinar demonstrações financeiras e opinar sobre propostas dos órgãos da administração;

- Os membros do conselho fiscal assistem às reuniões do conselho e/ou da diretoria.

Na situação específica das fundações, entretanto, é importante destacar que tudo está condicionado pelo ato de instituição do fundador - nas associações, por outro lado, são os sócios que, reunidos em assembléia, têm o poder de elaborar ou alterar os estatutos. Nas fundações existem no mínimo três órgãos:

${ }^{21}$ Lei $6.404 / 76$ 
(a) Um conselho curador (ou deliberativo), responsável por definir as metas e diretrizes da entidade, expressando a todo momento a vontade dos instituidores;

O que se deseja e espera de um conselho curador é que ele efetivamente participe da vida fundacional, conhecendo, orientando e vivenciando suas atividades finalísticas. (PAES, 1999)

(b) Uma diretoria administrativa, encarregada da execução e gerência da entidade; e

(c) Um conselho fiscal, responsável pelo controle interno contábil e patrimonial da fundação.

"É interessante que seus integrantes não tenham vínculos, sejam funcionais, sejam afetivos, com o instituidor ou com os demais conselhos. O ideal mesmo é que o conselho fiscal seja integrado por especialista, nas áreas de contabilidade ou direito" (RESENDE ${ }^{22}$, citado por PAES, 1999)

PAES faz uma importante distinção entre o conselho e a diretoria:

A única distinção, insisto, entre a diretoria e o conselho é a forma de decisão. $\mathrm{Na}$ diretoria, ela é individual, em regra, ao passo que no conselho ela é sempre deliberativa ou colegial. Mesmo quando a decisão da diretoria sobre determinadas matérias for tomada em reunião, não logra o órgão revestir-se de caráter colegial. Apesar de ser coletiva a decisão, o poder de executá-la é individual, ou seja, daquele diretor que o estatuto para tanto designou.

Em síntese, este contexto legal tradicional não determina a existência formal de um conselho nas associações e sociedades sem fins lucrativos - exceto nas fundações - exigindo pelo menos uma assembléia geral, uma diretoria e um conselho fiscal. Por outro lado, fica a impressão de que o "papel de conselho" pode ser exercido tanto pela assembléia geral, como pela diretoria.

O contexto legal acima explicita uma certa característica colegiada ao conselho que é importante, pois ela determina que o conselho só tome decisões em conjunto, não individualmente. Poder individual, limitado pelos estatutos, é conferido somente aos diretores.

Por fim, vale destacar mais uma vez que aquelas pessoas encarregadas da direção da organização normalmente têm que ser voluntárias para que a organização tenha direito à isenção do imposto de renda e a qualificar-se como de utilidade pública.

Duas novas leis trouxeram perspectivas novas para o marco legal do terceiro setor: a lei das OSCIPs e a lei das OSs, como se verá a seguir.

\subsubsection{LEI DAS OSCIPS}

Recentemente, após várias rodadas de diálogo e consulta a instâncias organizadas do setor, a Lei 9.790/99 foi promulgada com a finalidade explícita de fortalecer iniciativas da sociedade civil que efetivamente têm

${ }^{22}$ RESENDE, T.A. Novo manual das fundações. Belo Horizonte: Inédita, 1997. 
finalidade pública. Essa lei qualifica as Organizações da Sociedade Civil de Interesse Público - OSCIPs, possibilitando firmar parcerias entre Estado e sociedade civil com maior facilidade e eficácia ${ }^{23}$. Esta lei é vista como um passo na reforma do marco legal do terceiro setor, que visa aumentar a possibilidade das populações influírem nas decisões públicas e alavancar novos recursos ao desenvolvimento do país ${ }^{24}$. Ela visa ainda implementar mecanismos adequados de controle social e responsabilização das organizações para que os recursos estatais por elas adminis trados sejam efetivamente aplicados em fins públicos - 0 principal mecanismo é o Termo de Parceria.

A lei das OSCIPs, conforme explicitado no prefácio do seu documento de apresentação e esclarecimento (Ferrarezzi, op. cit.):

...permite remunerar dirigentes, pondo fim a uma hipocrisia institucionalizada, que vigora há décadas no país: os verdadeiros dirigentes das organizações travestemse de funcionários executivos colocando "laranjas" nas diretorias de suas entidades; e fazem-no para não perder velhos títulos que Ihes dão direitos a benefícios, como a Utilidade Pública Federal. Além disso, ocorre que a legislação em vigor não reconhece como isentas do Imposto de Renda aquelas entidades que remuneram dirigentes.

Além da qualificação como de interesse público, da abrangência de benefícios a maior número de organizações e do acesso a recursos públicos, essa lei altera os mecanismos de planejamento, avaliação e controle de projetos que utilizam recursos estatais. Para isso, entre outras coisas:

- A ênfase do controle se concentra no alcance de resultados.

- São imputadas punições severas para o uso indevido de recursos, prevendo se a indisponibilidade dos bens dos responsáveis.

- Uma comissão de avaliação- composta por representantes do órgão estatal parceiro, do conselho de Política Pública e da OSCIP- avalia o Termo de Parceria e verifica o desempenho global do projeto em relação aos benefícios obtidos para a população.

- Acima de R\$600 mil, a OSCIP deve contratar auditoria independente para avaliar o Termo de Parceria.

- Qualquer cidadão pode requerer, judicial ou administrativamente, a perda da qualificação de uma entidade como OSCIP.

- É livre o acesso às informações referentes às OSCIPs junto ao Ministério da Justiça.

\footnotetext{
${ }^{23}$ Esta lei não substitui a Declaração de Utilidade Pública Federal, fornecida pelo Ministério da Justiça, e o Certificado de Fins Filantrópicos, fornecido pelo CNAS.

${ }^{24}$ FERRAREZZI, E. OSCIP - Organização da sociedade civil de interesse público: a lei $9.790 / 99$ como alternativa para o terceiro setor. Brasília: Comunidade Solidária, 2000.
} 
A Lei das OSCIPs permite (e não obriga) que sejam remunerados os dirigentes que atuam na gestão executiva da entidade ou prestam a ela serviços específicos, desde que respeitados os valores praticados na região onde atua (porém, neste caso ela não terá isenção do Imposto de Renda). A intenção por trás desta prerrogativa é favorecer a profissionalização do quadro funcional das entidades.

A lei das OSCIPs faz a exigência formal da existência apenas de um conselho fiscal, mas o modelo de estatuto proposto também sugere a existência da diretoria e da assembléia geral (composta pelos sócios).

\subsubsection{LEI DAS OSS}

Enquanto as OSCIPs são a publicização do privado, as OSs - Organizações Sociais - são a privatização do público - isso expressa uma "atração entre o Direito Público e o Direito Privado".

As OSs são entidades privadas, criadas por iniciativa do poder público, que nascem vinculadas a um Contrato de Gestão de certo patrimônio público, cedido (e não transferido) a elas pelo Estado. Olak (2000) ${ }^{25}$ avalia que as OSs são elementos importantes da reforma do aparelho do Estado, proposta em 1995, sob a palavra de ordem da parceria com organizações sem fins lucrativos de direito privado, a partir de uma orientação mais gerencial do que burocrática (a ênfase muda dos meios para os fins).

A lei das OSs estipula expressamente que a entidade deve ter, como órgãos de deliberação superior e direção, um conselho de administração e uma diretoria. É prevista a participação de membros do poder público e representantes da sociedade civil no conselho de administração. Com isso objetiva-se fortalecer a participação da sociedade tanto na formulação quanto na avaliação do desempenho da organização social, viabilizando o controle social.

A composição do conselho de administração é especificada na lei, que exige que:

(a) 20 a 40\% dos membros natos sejam representantes do Poder Público;

(b) 20 a $30 \%$ de membros natos sejam representantes de entidades da sociedade civil $^{26}$;

(c) até $10 \%$, no caso de associação civil, dos membros sejam eleitos dentre os membros ou os associados;

(d) 10 a $30 \%$ dos membros sejam eleitos pelos demais integrantes do conselho, dentre pessoas de notória capacidade profissional e reconhecida idoneidade moral;

(e) até $10 \%$ dos membros sejam indicados ou eleitos na forma estabelecida pelo estatuto.

O mandato pode ser de até 4 anos, admitindo-se uma econdução. Os conselheiros que integrarem a diretoria devem renunciar ao assumir funções executivas. O conselho deve reunir-se pelo menos três vezes por ano, tendo como atribuições principais: fixar o âmbito de atuação da entidade, aprovar o contrato de gestão, aprovar o orçamento e o programa de investimentos, fiscalizar o cumprimento das diretrizes e metas.

${ }^{25}$ OLAK, P.A. Eficácia na aplicação do Contrato de Gestão nas Organizações Sociais Brasileiras. Tese de Doutorado em Ciências Contábeis. São Paulo: FEA/USP, 2000.

${ }^{26}$ (a) e (b) juntos devem compor pelo menos $50 \%$ do conselho de administração. 
Diferentemente das OSCIPs, todas as OSs são declaradas automaticamente de utilidade pública, tendo direito a todas as isenções de impostos que ela dá direito. Ao conselho cabe, além de aprovar a proposta de Contrato de Gestão (inclusive indicadores de desempenho pré-definidos), negociar com a entidade supervisora.

Portanto, nessa nova modalidade de organização, o conselho de administração é explicito e tem um papel primordial, tanto no direcionamento institucional, quanto na definição e negociação das bases sobre as quais se dará o contrato de gestão (um mecanismo de controle social passa a ser a adoção de indicadores de desempenho). Um ponto característco das OSs, entretanto, é o controle externo, dado pela participação de representantes do governo e da sociedade civil no conselho.

Apesar de qualquer entidade, uma vez atendidos os requisitos da lei, poderem qualificar-se como OS, poucas o estão fazendo.

\subsubsection{UMA PASSADA PELA LEGISLAÇÃO EMPRESARIAL}

No caso das empresas, os artefatos legais de certa maneira visam garantir o controle da propriedade sobre a gestão. No caso das sociedades de capital aberto, os três principais mecanismos são o conselho de administração, a auditoria independente e o conselho fiscal.

Falando sobre o ambiente corporativo, Santos $(2000)^{27}$ relata que, no Brasil, as corporações de capital aberto são obrigadas, por lei (Lei 6404/76), a manter um conselho de administração formalmente instituído e os membros destes conselhos são considerados, pelo menos em teoria, pessoas da confiança dos acionistas, realizando a interface entre a direção da corporação e os donos do capital. O membro do conselho de administração, além de representar os acionistas nos processos de governança da corporação, contribui com sua reputação para tornar mais confiável a gestão da corporação, garantindo probidade e isenção ao sistema de governança.

A governança destas empresas é tratada segundo a Lei 6404/76, nos artigos 140 a 142 . Resumidamente, a lei estabelece que o conselho deve ser composto por no mínimo três membros, com mandato de no máximo 3 anos (permitida a reeleição), Ihe competindo:

I - Fixar a orientação geral dos negócios da corporação;

II - $\quad$ Eleger e distribuir os diretores da corporação e fixar -lhes as atribuições observando o que a respeito dispuser o estatuto;

III - Fiscalizar a gestão dos diretores, examinar, a qualquer tempo, os livros e papéis da corporação, solicitar informações sobre os contratos celebrados e em via de celebração e quaisquer outros atos;

IV - $\quad$ Convocar assembléia geral quando julgar conveniente, ou no caso do art. 132;

V - Manifestar - $\quad$ se sobre o relatório da administração e as contas da diretoria;

${ }^{27}$ SANTOS, H.M. Conselhos de administração: um estudo do funcionamento da governança corporativa. Dissertação de Mestrado. São Paulo: FEA/USP, 2000. 
VI - Manifestar - $\quad$ se previamente sobre atos ou contratos, quando o estatuto assim o exigir;

VII - Deliberar, quando autorizado pelo estatuto, sobre a emissão de ações ou de bônus de subscrição;

VIII - Autorizar, se o estatuto não dispuser em contrário, a alienação de bens do artigo permanente, a constituição de ônus reais e prestação degarantias a obrigações de terceiros;

IX - Escolher e destituir os auditores independentes, se houver.

Santos (op. cit.) comenta que a legislação brasileira não contempla aspectos como diversidade na composição, limites para participação em conselhos, avaliação de conselheiros e executivos, comitês e responsabilidades legais, entre outros aspectos.

\subsection{O QUE ESTÁ ACONTECENDO NAS EMPRESAS}

Ao que tudo indica, o processo de globalização, o advento das corporações transnacionais, a facilidade de investir e transferir dinheiro eletronicamente, movimentos como da cidadania empresarial e da responsabilidade social, paralelamente ao fortalecimento da sociedade civil e à reformulação do papel do Estado, estão tendendo a afetar também a forma como as empresas têm que ser governadas.

No âmbito internacional as empresas estão sendo levadas a adotar códigos ${ }^{28}$ disciplinadores da atuação dos conselhos de administração. Há movimentos que contestam o simples papel de representação dos interesses dos acionistas nos conselhos de administração, argumentando que a corporação de capital aberto tem uma importante função social e que o conselho deve auxiliar na compatibilização dos interesses dos diferentes grupos intervenientes (Santos, op. cit.). Valoriza-se especialmente uma função mais independente do conselho. Está tomando força o conceito da Governança Corporativa.

Este movimento está se refletindo no Brasil, tendo culminado, em 1995, com a fundação do Instituto Brasileiro de Governança Corporativa ${ }^{29}$. A missão do Instituto é otimizar o conceito de governança corporativa nas empresas do país. Para isso, visa cooperar com o aprimoramento do padrão de governo das empresas nacionais. No ponto de vista deles, a boa governança corporativa assegura aos sócios eqüidade, transparência e responsabilidade pelos resultados (accountability). Pressupõe-se que os conselheiros nem sempre estão bem preparados para desempenhar convenientemente a sua função e essa deficiência tem sido a raiz de grande parte dos problemas e fracassos no governo das empresas. Estimulase o aparecimento de conselheiros profissionais e independentes.

Concretamente, o IBGC, uma sociedade civil de âmbito nacional sem fins lucrativos, organizou em conjunto com o Banco Mundial, a OCDE - Organização para Cooperação e Desenvolvimento Econômico, a BOVESPA e a CVM, o "The Latin American Corporate Governance Roundtable, em abril de 2000. Em novembro do mesmo ano promoveu o $1^{\circ}$ Congresso Brasileiro de Governança Corporativa, reunindo 190 pessoas. O Instituto promove cursos de orientação e aprofundamento sobre o tema, realiza pesquisas e divulga idéias e conceitos relacionados, congregando atualmente pelo menos 220 sócios de mais de 25

\footnotetext{
${ }^{28}$ Os primeiros códigos surgiram em 1992.

${ }^{29}$ Fonte: IBGC - Instituto Brasileiro de Governança Corporativa, material institucional.
} 
cidades do país. Desde a sua fundação, conseguiu quadruplicar o número de sócios. O Instituto é dirigido por um conselho de administração, uma diretoria e quatro comitês permanentes.

Num pequeno artigo em que traça um panorama geral do processo de governança em empresas, Hallqvist $(2001)^{30}$ descreve que o controle concentrado das companhias é comum no Brasil, havendo a existência de um controlador que é, ao mesmo tempo, executivo principal e presidente do conselho de administração. Muitas multinacionais instaladas no país dependem da sua matriz e operam sob um CEO poderoso. Poucas empresas têm um conselho de Administração que efetivamente funciona, possuindo, por causa dessa ineficiência, um conselho fiscal (órgão que, segundo ele, não se encontra em países onde se adotam práticas de boa governança corporativa).

Segundo Rodrigues (2001) ${ }^{31}$, a partir de outubro de 2000 o BNDES passou a exigir a adesão às boas práticas de governança corporativa para conceder financiamentos a pequenas empresas, devendo ser em breve também um critério para o ingresso de companhias abertas no Novo Mercado, pregão a ser criado na BOVESPA só com empresas que emitam ações ordinárias.

O IBGC elaborou o primeiro Código Brasileiro das Melhores Práticas de Governança Corporativa, focado no conselho de administração. O Código foi construído com base na lei das sociedades anônimas, na discussão com um grupo representativo de empresários e associados e na análise de 15 códigos internacionais da mesma natureza. Seu lançamento ocorreu em maio de 1999, já tendo sido distribuídos mais de 6.000 exemplares.

Resumidamente, o Código das Melhores Práticas Corpor ativas desenvolvido pelo IBGC propõe que:

1. A missão do conselho de Administração é proteger o patrimônio e maximizar o retorno do investimento dos acionistas, agregando valor ao empreendimento e zelando pelos valores, crenças e propósitos dos acionistas.

2. As atividades de competência do conselho devem estar normatizadas em um regimento interno, tornando claras suas responsabilidades e atribuições.

3. Só o conselho pleno pode tomar as decisões; os comitês realizam análises profundas que tomam mais tempo do que o disponível nas reuniões.

4. O tamanho do conselho de administração deve ser o menor possível, variando, em função do perfil da empresa, entre 5 e 9 membros.

5. A maioria do conselho deve ser formada por conselheiros independentes, devendo haver diversidade de conhecimentos e experiências.

${ }^{30}$ HALLQVIST, B. Panorama feito por Bengt Hallqvist, presidente do IBGC. In: Clipping do IGBC. Nr. 4, Janeiro-Fevereiro 2001

${ }^{31}$ RODRIGUES, L. Empresas e investidores em lua-de-mel. Reportagem publicada no Jornal O Globo em 13/11/2000. In: Cllipping do IBGC. Nr. 4 Janeiro-Fevereiro 2001. 
6. O mandato deve ter duração curta, entre 1 e 3 anos, sendo a reeleição possível depois de uma avaliação formal de desempenho; deve-se evitar a acumulação de cargos entre conselheiros e diretores.

7. Os conselheiros devem ter o direito de fazer consultas a profissionais externos pagos pela empresa; e cada novo conselheiro deve ser exposto a um programa de introdução.

8. A cada ano deve ser feita uma avaliação formal do desempenho do conselho e de cada conselheiro individualmente; os sistemas de avaliação (também da diretoria) devem ser explicados no relatório anual da empresa. É função do conselho avaliar a gestão da diretoria.

9. No relatório anual deve haver uma indicação de qual o código das melhores práticas usado pela empresa e dos desvios que porventura ocorreram.

10. Decisões tomadas devem ficar registradas em ata fidedigna.

Santos (2000) fez uma pesquisa sobre a adoção das práticas relacionadas no Código do IBGC em 46 das 120 corporações registradas na CVM e presentes no ranking das maiores e melhores da Revista Exame. Com base neste estudo ele afirma:

\section{A pesquisa mostrou que, mesmo nas corporações familiares e nas que têm donos individualmente identificáveis, os processos de profissionalização são claros e as exigências para escolha dos conselheiros são cada vez maiores.}

Mesmo assim, 27\% das empresas não têm membros independentes nos conselhos, a participação da mulher $(24,3 \%)$ e de minorias étnicas $(18,9 \%)$ é bastante baixa, e em $86,5 \%$ dos casos não há avaliação formal dos conselhos. Embora a maioria dos entrevistados afirmasse que deseja limitar o mandato dos conselhos, isso não acontece na prática da maioria. Muitos defendem a existência de comitês diversos para operacionalizar a ação dos conselhos, mas poucos o fazem. Por outro lado, a questão ética vem assumindo relevância, conforme constatou aquele pesquisador:

Com relação àética e conduta corporativa, o conselho evidencia ser o principal responsável atual por cuidar disso, conjuntamente com a administração, representando isso uma inovação no comportamento organizacional.

Menos otimista, entretanto, é a perspectiva construída por Monaco (2000) ${ }^{32}$, após um estudo sobre a composição dos conselhos de administração e instrumentos de controle das S.As. no Brasil. Ele constatou que o tema conselhos de administração está ainda estágio quase embrionário e que as empresas por ações ainda não aderiram à idéia dos conselhos como instrumentos de controle. Na prática, estes conselhos têm um papel muito mais consultivo e político. Ele considera isso um "desvio de papel" (a lei atribuiria um papel controlador), afirmando que os interessados poderiam optar por outras soluções de governança, caso não houvesse a obrigatoriedade legal. Ele relaciona isso à participação de externos no conselho, sob o pressuposto, duvidoso para Monaco, de que terceiros não envolvidos numa negociação podem interferir na

\footnotetext{
${ }^{32}$ MONACO, D.C. Estudo da composição dos conselhos de administração e instrumentos de controle das sociedades por ações no Brasil. Dissertação de Mestrado. São Paulo: FEA/USP, 2000.
} 
mesma. O contexto, segundo ele, sugere que somente os interessados têm algo a dizer sobre as resultantes de uma atividade econômica. No Brasil, o uso de outros instrumentos de controle, como por exemplo a concentração de controle acionário, sugerem que o conselho de administração é preterido no papel de controle.

Lodi (2000) ${ }^{33}$ informa que governança corporativa é um novo nome para o sistema de relacionamento entre acionistas, auditores independentes e executivos da empresa, liderado pelo conselho de administração. Nos debates que existem sobre o assunto, uma das questões mais fortes em aberto é se a empresa existe para atender aos seus acionistas ou para atender a seus stakeholders ${ }^{34}$, um grupo de interesses mais amplo composto de empregados, fornecedores, clientes, cidadãos, etc. O conselho é considerado um mediador político entre pressões opostas pelo grupo que defende a stakeholder corporation. Este grupo também defende que é dever da empresa maximizar os ganhos do acionista, porém de uma forma responsável levando em conta o longo prazo. O conselheiro tem obrigações perante os diversos constituintes da empresa e uma distinção que está em jogo é a diferença entre "levar em conta" e "ser responsável diante de", segundo Lodi.

Lodi relata ainda que o movimento da governança corporativa começou a ser considerado seriamente pela alta administração das empresas quando, em 1998, vinte chefes de grandes empresas internacionais de 16 países reuniram-se em Londres para formar o conselho Global de Governança Corporativa. Nessa reunião foram identificados quatro princípios de governança:

1. O conselho precisa ser responsável para com os acionistas;

2. O conselho precisa ser independente dos gestores;

3. Os papéis de presidente do conselho e presidente da empresa não podem ser exercidos pela mesma pessoa.

4. As empresas precisam preencher certos padrões internacionais para se qualificarem a serem listadas em uma Bolsa de Valores.

Os códigos das melhores práticas aparecem, segundo ele, em função de crises por que passaram as grandes corporações mundiais, por pressão dos fundos de pensão e de investimento, em função de escândalos financeiros e por pressão de organismos privados. O movimento da governança corporativa toma força ainda graças ao desejo de países emergentes em atrair investimentos externos: com a adoção de princípios que reforçam a transparência contábil, probidade administrativa, respeito æ̀s leis, argumentase, é valorizado o retorno do investimento dos acionistas. Apesar disso, Lodi afirma:

${ }^{33}$ LODI, J.B. Governança corporativa: o governo da empresa e o conselho de administração. Rio de Janeiro: Campus, 2000.

${ }^{34}$ HORNBY, A.S., no Oxford Advanced Learner's Dictionary of Current English (Oxford: Oxford University Press, 1995), define stakeholder como uma pessoa, companhia, etc. que tem ações ou interesses em um negócio ou indústria. 
No Brasil, com honrosas exceções, os conselhos são ainda criaturas do presidente ou até figuras de papel. Conselheiros externos são convidados para adornar com seus nomes ou ilustrar com "palestras" s obre o momento econômico, mas raramente se envolvem nas verdadeiras decisões que exigem um aprofundamento sobre o ramo da empresa. Presidentes fortes ou controladores majoritátios preferem conselhos consultivos, que opinem mas não decidam e que referendam decisões já tomadas pelos insiders.

É interessante notar que Peter Drucker em 1984 já afirmava:

As legislações nacionais estipulam diferentes composições para esse conselho. Mas uma coisa é comum a todos eles, independentemente de sua posição jurídica: eles não funcionam. O declínio do conselho, neste século, é um fenômeno universal.

\subsection{IMPLICAÇÕES}

É dentro deste contexto econômico, social e legal que as organizações da sociedade civil têm a oportunidade de operar e do qual pode se estruturar os seus mecanismos de governança. Nota-se claramente que há um movimento para garantir mecanismos de participação da sociedade civil nas decisões, bem como uma preocupação com eficiência, transparência e prestação de contas dos gastos dos recursos públicos. Nota-se também, que a obrigatoriedade de existência de um conselho formal acontece somente nas fundações e nas OSs; nas demais organizações a definição de quem dirige a entidade é vinculada ao estatuto, no qual aparece normalmente uma diretoria.

O que fica claro, entretanto, é que órgãos como as diretorias e os conselhos das organizações (com e sem fins lucrativos) controlam e/ou influenciam muitos dos acontecimentos, das tendências e questões relacionadas à vida civil neste país. Quer um cidadão esteja num banco, atravessando a rua ou trabalhando, possivelmente vai estar sendo afetado por decisões tomadas por um grupo de pessoas a partir de um conjunto de interesses e propósitos. Quer queira-se ou não, isso faz parte da vida moderna - e pode ter conseqüências sociais mais ou menos positivas, dependendo da forma como é tratada. 


\section{Segunda Parte: O Contexto Organizacional}

\subsection{RAÍZES HISTÓRICAS DA EXISTÊNCIA DE CONSELHOS}

A literatura brasileira sobre governança de organizações da sociedade civil é restrita, exigindo que um interessado no assunto se utilize tanto de informações da área empresarial, quanto de bibliografia internacional, especialmente as de língua inglesa, para desenvolver parâmetros sobre o tema. Em função disso, é preciso cuidado ao se fazer uma incursão por referências internacionais, pois nem sempre os conceitos utilizados em outros países "casam" perfeitamente com a realidade brasileira - é exigida uma tradução literal dos termos, simultânea a uma tradução contextual dos mesmos.

Assim, um brasileiro ao fazer um levantamento da literatura estrangeira especializada em governança deparase com os termos board, board of trustees, board of directors, stakeholders e accountability. Estes termos podem ser traduzidos de formas diferentes, dependendo do contexto em que são utilizados. Um dicionário especializado na área jurídica ${ }^{35}$ define (traduz) alguns termos ligados à governança da seguinte maneira:

$$
\begin{aligned}
& \text { Board - diretoria; junta; banca; conselho administrativo. } \\
& \text { Board of directors - conselho de administração. } \\
& \text { Board of trustees - administradores. } \\
& \text { Accountability - responsabilidade sujeita a prestação de contas. }
\end{aligned}
$$

Um dicionário mais especializado na área de negócios ${ }^{36}$ traduz os mesmos termos assim:

Board - junta. Grupo de pessoas, geralmente não menos de três, com a responsabilidade de dirigir uma determinada função oficial pública. O termo "comissão", bem como "conselho", geralmente são intercambiáveis com "junta". Por extensão, o termo também se aplica ao setor privado.

Board of directors - diretoria.

Trustee - curador; fideicomisso. 1. Pessoa ou entidade a quem são confiados bens de terceiros para serem administrados. O mesmo que curador. 2. Um dos vários nomes para fideicomisso, síndico, depositário, administrador de fundos de terceiros etc.

Accountability - responsabilidade final. Em administração de empresas, via de regra o termo está vinculado a uma delegação de poderes. Presumivelmente, o indivíduo ao qual se atribui responsabilidade recebe autoridade comensurável, e

\footnotetext{
${ }^{35}$ GOYOS JÚNIOR, D.N. Noronha's Legal Dictionary: English-Portuguese. $1^{\mathrm{a}}$, ed. São Paulo: Observador Legal Editora Ltda., 1992.

${ }^{36}$ DIC Prático Michaelis Versão 5.1. DTS Software Brasil Ltda. Maio de 1998.
} 
mesmo que delegue responsabilidade e autoridade a terceiros, será ainda o responsável final perante seu superior. Se numa mesma frase encontrássemos os termos responsibility e accountability, poderíamos dizer que a primeira é responsabilidade primária e que a segunda é responsabilidade final. Portanto, accountability deve ser um grau mais alto de responsabilidade. Seu fenômeno é que a prestação de contas é devida a um escalão superior. Um supervisor tem responsabilidade perante um subordinado, mas não Ihe presta contas. Somente o faz às autoridades superiores.

Stakeholder - depositário de dinheiro de apostas.

Ao utilizar um dicionário especializado na língua inglesa ${ }^{37}$, chega-se aos seguintes resultados (traduzidos por este pesquisador):

Board - um grupo de pessoas controlando uma empresa ou outra organização; um comitê ou conselho.

Director - (a) pessoa que dirige ou controla um grupo de pessoas trabalhando juntas ou uma instituição, uma faculdade, etc.; (b) membro de um grupo sênior de pessoas que gerencia os negócios de uma empresa; (c) pessoa encarregada de um filme, peça, etc. que supervisiona e instrui os atores, equipe de câmeras e outros.

Trustee - (a) pessoa que é responsável por um patrimônio; (b) membro de um grupo de pessoas gerenciando os negócios de uma instituição.

Accountable - requerido ou esperado a dar uma explicação sobre as ações, gastos, etc. de alguém; responsável.

Stakeholder - uma pessoa, empresa, etc. que tem cotas ou algum interesse num empreendimento ou indústria.

Para ilustrar, verificou-se que as definições dadas por um dicionário especializado na língua portuguesa ${ }^{38}$ para diretoria e conselho são:

Conselho - do latim consilium, deliberação - (a) opinião, parecer, juízo; (b) aviso, advertência; (c) assembléia de pessoas que deliberam sobre certos assuntos; (d) grupo de pessoas encarregadas de administrar, de dirigir.

Diretoria - (a) cargo, ofício de diretor; (b) os membros encarregados de uma direção.

${ }^{37}$ HORNBY, A.S. Oxford Advanced Learner's Dictionary of Current English. 5a ed. Oxford, Inglaterra: Oxford University Press, 1995.

${ }^{38}$ LOVISOLO, E., PEREIRA, B.H.A. \& POZZOLI, T.C. Larousse Cultural: Dicionário da Língua Portuguesa. São Paulo: Nova Cultural, 1992. 
Direção - do latim directio, alinhamento - (a) ação de dirigir; (b) administração, comando, governo; (c) função de diretor; (d) sede de serviços, superintendência;

(e) lado para o qual alguém se dirige, rumo.

Sendo a contribuição da legislação para definir adequadamente governança, conselho e diretoria também limitada e, em termos, dúbia, faz-se necessária a busca de um pouco de história (a que existe disponível) para entender corretamente estes conceitos. Por enquanto, adota-se o termo conselho para a tradução da palavra inglesa board.

No decorrer da construção deste trabalho, foram encontradas duas referências específicas sobre a história dos conselhos nos Estados Unidos. O primeiro relato é feito por Houle $(1997)^{39}$, sobre vários grupos decisórios de pessoas que agiam como conselhos.

Em Florença, na Itália, por exemplo, a Irmandade de Misericórdia tem existido continuamente desde 1240. Seus membros não remunerados, que contam cerca de 6.000 atualmente, concordaram em contribuir pelo menos com uma hora por semana com serviços comunitários e em fazer isso pelo resto da vida. Essa organização tem sido dirigida por mais de setecentos anos por uma liderança administrativa voluntária e por um grupo governador que agora tem setenta e dois membros saídos da aristocracia, do clero, empresários, profissionais e trabalhadores...

A Universidade de Harvard é considerada por Houle o primeiro caso em que uma diferenciação de órgãos dirigentes mostrourse efetiva.

De forma geral, segundo ele, conselhos eram raros nos tempos da colonização. Porque a maioria das pessoas que dependiam da sua própria iniciativa e talento para desbravar novas terras, construir seus abrigos, vestir-se e ainda alimentar alguns familiares, eram também pessoas que esperavam ter voz direta nas decisões que afetavam suas vidas. Num relato clássico da história americana, Houle descreve reuniões "municipais" democráticas (mesmo após a existência de governo) onde cada assunto público (desde a localização de uma bomba até a seleção de um diretor para a escola) era decidido por voto popular, após terem sido ouvidos todos os argumentos.

Quanto menor a comunidade, mais caloroso o debate.

Conforme a vida tornou-se mais complexa, as pessoas passaram a não mais poder influenciar todas as decisões relativas à sociedade. Criaram-se instituições como os conselhos municipais (city councils), os legisladores e o congresso, para lidar com assuntos públicos. Com o tempo tam bém formaram-se órgãos específicos responsáveis por escolas, postos de saúde, bibliotecas, universidades, museus e abrigos para portadores de necessidades especiais.

Nas primeiras iniciativas privadas com fins coletivos, como clubes, sindicatos, grupos de caridade e outras formas de associação voluntária, todos os membros participavam de todas as decisões. Com seu

${ }^{39}$ HOULE, C.O. Governing Boards: their nature and nurture. San Francisco: Jossey Bass, 1997. 
crescimento e amadurecimento tornou-se necessária alguma forma de delegação de responsabilidade, resultando na criação de diretorias e conselhos (ou qualquer outro nome que se queira dar).

Mesmo em empreendimentos iniciados, liderados e patrocinados por uma só pessoa, quando os serviços crescem e aumentam em complexidade, ou quando o vigor do líder começa a declinar e seu carisma perde poder, essa diferenciação começa a se fazer necessária. Houle afirma que aqueles que inicialmente são aconselhadores ou patrocinadores gradualmente assumem responsabilidade por preservar a instituição, através da formalização de políticas e tarefas...

A sombra do fundador estende-se na criação de um conselho. ...

Este processo ocorre natural e universalmente, sugerindo que a maioria dos conselhos modernos não evoluiu de uma prévia estrutura organizacional, mas começou a existir no mesmo momento que os serviços que eles controlam foram criados.

Hall $(1997)^{40}$ fez um estudo mais amplo e politizado da história dos conselhos (ou diretorias) das organizações sem fins lucrativos nos Estados Unidos. Para ele, apesar de poucas práticas serem mais antigas do que comunidades delegando autoridade (para pequenos grupos de anciãos, diáconos, proprietários, legisladores, conselheiros, diretores ou curadores), as responsabilidades formais e as expectativas informais sobre sua atuação varia de tempos em tempos, de lugar para lugar.

As atribuições de anciãos tribais das sociedades mais tradicionais obviamente diferem das responsabilidades, autoridade e métodos dos membros da Academia de Cardeais da Igreja Católica Romana, do conselho de administração da General Motors e dos membros e supenisores da Harvard Corporation.

Para o entendimento de todas as dimensões da governança contemporânea, o autor refere-se à imagem de uma antiga fórmula legal de propriedade da terra: a do "feixe de lenha". Segundo ele, a posse da terra tradicionalmente envolvia vários direitos de uso - o direito de cultivar, de extrair madeira, de passagem, de ocupação e daí por diante - e somente num passado recente é que tornou-se aceito o conceito de posse como propriedade. Hall entende sua pesquisa como um "desmantelar do feixe" de direitos, leis, expectativas e pressupostos que compreendem o processo de governança liderado por um conselho (ou diretoria).

Retornando-se ao período colonial encontra-se o que ele considera o primeiro conselho americano. Naquele tempo, muitas das colônias eram controladas por companhias privadas, de propriedade de um determinado grupo de indivíduos. Uma dessas companhias - Massachusetts Bay Company - tinha uma escritura que garantia o direito de sucessão perpétua, que dava ao seu grupo de proprietários o poder de indicar seus sucessores e de escolher dirigentes. A companhia então nomeou 13 homens, escolhidos por sua honestidade, sabedoria e conhecimento, para conduzir o governo colonial. Neste caso, foi ainda determinado o intervalo de tempo no qual este governo deveria reunir -se (pelo menos a cada 4 meses) e o quorum necessário, dando-lhe poder para fazer leis e normas.

\footnotetext{
${ }^{40}$ HALL, P.D. A History of Nonprofit Boards in the United States. Washington: National Center for Nonprofit Boards, 1997.
} 
A escritura da Massachusetts Bay Company - que criou o primeiro conselho americano - ilustra a falta de distinção entre os domínios público e privado. Houve mais do que a doação de posse - também foi delegado o direito de governar.

Tanto grupos ligados à Igreja, quanto governamentais apropriaram-se deste paradigma e adotaram estruturas semelhantes, dando aos grupos de decisão um caráter de representação do povo: eles serviam àqueles que os escolhiam. Claramente, entretanto, características democráticas eram distorcidas por normas informais de deferência aos mais ricos, instruídos e nobres. O posterior questionamento destas normas levou àconstituição de critérios mais transparentes.

A Universidade de Harvard foi estabelecida em 1636 por legisladores públicos - ela foi criada sob a autoridade de um conselho composto por 12 "supervisores", incluindo seis magistrados e seis ministros. Eles viam a si próprios como representantes do interesse público. Em 1650 foi emitido um documento formal de incorporação, propiciando o controle das propriedades e provendo maior autonomia na gestão de suas atividades. Isso fez com que a governança da Universidade fosse dividida em dois órgãos: (a) o presidente e seus colegas, representando a organização privada; e (b) os supervisores, com poder de veto de decisões e intervenção em casos extremos. Daí para frente houve muita disputa pelo poder sobre Harvard, entre grupos de natureza religiosa e grupos leigos apoiados por políticos da época. Essas disputas levaram àbusca de estruturas de governo que não fossem nem controladas por políticos, nem fossem autosuficientes, mas que promovessem o bem da institu ição e do público.

A Universidade de Yale (1701) surgiu na esteira de Harvard, mas optou por somente um conselho, composto por membros não residentes do clero. Controvérsias refletindo as tensões da época acabaram por ocasionar uma maior clarificação do poder dos seus curadores, entre os quais a liberdade de fazer seus próprios estatutos. Tensões religiosas posteriormente levaram à tentativa de uniformização do conselho (todos teriam que pensar da mesma maneira), que foi impedida pelo argumento de que os conselheiros tinham sim o direito de orientar-se pelo seu julgamento pessoal e de discordar da maioria.

Com o advento da Revolução Americana, organizações sectárias como Harvard e Yale passaram por sérias dificuldades financeiras, exigindo que alterassem suas relações com a comunidade ao seu redor. Harvard acabou por colocar leigos em seu conselho e por construir vínculos com a comunidade de negócios em Boston. Yale, ao contrário, optou inicialmente por buscar maior apoio dos legisladores estaduais, esperando obter maior suporte público. Isso representou ameaça em termos de autonomia e de enfraquecimento da inspiração religiosa (por exemplo, para obter um repasse foi necessário incorporar representantes estaduais no conselho), levando a Universidade a buscar apoio justamente em suas raízes religiosas: desenvolveu-se uma rede nacional de ex-alunos.

Quando as colônias declararam sua independência da Grã Bretanha, os legisladores defrontaram-se logo com uma questão premente: que leis seriam apropriadas a governos baseados na aprovação popular?

Neste novo contexto, conviveurse com duas abordagens diferentes para as iniciativas de caráter público: uma, influenciada por Thomas Jefferson, propunha que o governo teria poder absoluto sobre organizações de caridade e similares, tornando seus conselhos pouco mais do que agentes do governo; outra, dentro do 
contexto das leis inglesas, resguardava o direito de reunir-se, dando poderes únicos aos conselhos (advindos da delegação) e colocando as organizações sem fins lucrativos como guardiãs do direito privado.

Todos os americanos da época viam as organizações de caridade, religiosas e educacionais como empreendimentos públicos. A questão demandando solução era: quem é "o povo"?

A discussão entre o controle público versus o controle privado contribuiu para o avanço da noção de que a vontade do povo poderia ser expressa por outras maneiras além dos meios eleitorais e governamentais, legitimando a idéia da iniciativa privada associativa em favor do interesse comunitário.

Em virtude desta noção, começaram a surgir preocupações a respeito da tendência (ou risco) da concentração de poder nas mãos de poucos e com mecanismos específicos através dos quais pudesse haver a representação da visão da maioria e do povo. O desafio da accountability passou a incomodar muitos legisladores americanos do século dezenove. Isso acontecia ao mesmo tempo em que as organizações amadureciam e suas estruturas de governança se tornavam mais elaboradas, distanciando conselheiros do dia-a-dia e aumentando o poder de dirigentes assalariados, mais comprometidos com as exigências práticas do momento.

Um outro movimento aconteceu paralelamente, que foi a da exigência de voz pelos stakeholders destas organizações. Nas universidades de Harvard e Yale, por exemplo, os ex-alunos queriam participar do governo de suas escolas (1860). Este movimento era inspirado por questões como: Quem possui uma instituição de caridade? Quem tem se mobilizado para exigir "voz" nas decisões sobre seus negócios?

Ao final do século XIX, os conselhos da maioria das universidades americanas tornaram-se dominadas por homens de negócios e houve o surgimento de fundações doadoras, influenciando as prioridades de uma ampla gama de organizações. Internamente, duas culturas começaram a entrar em choque: a cultura acadêmica e a cultura empresarial, refletindo-se em comportamentos adversariais entre os conselhos e as equipes executivas.

Entre 1920 e 1930 surgiram os primeiros artigos sobre governança, orientados a questões relativas a eficácia, uso eficiente de recursos e accountability. Nestes anos, a formação de conselheiros foi direcionada para o desenvolvimento da comunidade e a inter-relação entre os poderes público e privado. Depois de 1930, o foco migrou para assuntos técnicos e preocupações relativas àvitalidade, eficiência e harmonia das organizações. Depois da segunda guerra mundial, a dimensão representativa da governança foi substituída pelas perspectivas e pelos métodos do profissionalismo gerencial. $O$ crescimento do número de organizações sem fins lucrativos a partir de 1950, paralelamente ao aumento do volume de subsídios diretos e indiretos (isenções e dedutibilidades) expandiram a demanda por gestores treinados.

Nos anos 80, ficou evidente (nos Estados Unidos, vale lembrar) o crescimento de organizações sem fins lucrativos com atividades comerciais, ao mesmo tempo que equipes executivas profissionalizadas e com um plano de carreira em mente diminuíam a importância dos conselhos - colocando-os muitas vezes em posição de meros "aprovadores". Tudo isso levou a uma crise na governança deste tipo de organizações, cujas primeiras tentativas de superar vieram das academias de ensino superior.

À época do governo Reagan houve muitos cortes de subsídios repassados às organizações sem fins lucrativos, que passaram a ter que buscar novas formas de suporte financeiro - recorrendo a tentar reavivar 
seus conselhos (sem no entanto, permitir que eles ficassem super-poderosos). O "desmantelamento" de instituições estatais através de políticas de privatização e desinstitucionalização também contribuiu fortemente para que fossem alterados, na prática, os procedimentos de governança das organizações sem fins lucrativos.

No final dos anos 80, um grande número de comentaristas afirmavam que os conselhos tinham se tornado irrelevantes. "Conselhos não são parte do núcleo técnico organizacional ... ao invés disso, o conselho é um artifício usado pela organização para gerenciar o ambiente organizacional”.

Os conselhos, também por mudanças legais, passaram a considerar menos os benefícios àcomunidade e, graças a novos mecanismos formais de prestação de contas, dedicar mais atenção às perspectivas financeiras.

No final dos anos 90, processos desencadeados por stakeholders de algumas organizações acadêmicas e da área da saúde dão sinais de que há uma tendência de dar maior peso, poder e primazia æ̀s audiências externas de cada organização sem fins lucrativos.

Apesar de não envolver diretamente os conselhos, estes esforços podem despertar diretores de organizações sem fins lucrativos para seu papel de depositários do interesse público....

De todos aqueles que escreveram sobre organizações sem fins lucrativos no último meio século, apenas um - Alan Pifer - tem se mostrado decidido a argumentar corajosamente e sem vergonha que essas organizações são, mais do que tudo, instituições privadas, sobre as quais os conselhos diretores são os únicos responsáveis legais. Pifer declarou, "Organizações sem fins lucrativos oferecem uma oportunidade especial ... para cidadãos conscientes ... de aceitar uma medida importante de responsabilidade pessoal pelo provimento de vários tipos de serviços essenciais ao povo. A aceitação deste tipo de responsabilidade possibilita a homens e mulheres laicas a tornar-se informadas sobre os grandes problemas nacionais."

No contexto desta declaração, Hall destaca, em primeiro lugar, que a oportunidade implícita para os conselhos não é de prover serviços aos necessitados, mas sim de devotar tempo e recursos para definir quais serviços devem ser prestados em favor da comunidade - transformando efetivamente a liderança organizacional em liderança comunitária. Finalmente, assevera que conselhos são muito mais do que a soma de valores individuais; são arenas nas quais membros individuais trabalham coletivamente sobre problemas e decisões que afetam as comunidades.

Ao se refletir sobre estas versões da história, começa a ficar evidente que existem algumas polaridades intrínsecas ao processo de governança das organizações não governamentais, sem fins lucrativos e de interesse público, com as quais conselheiros e diretores devem estar preparados para lidar:

↔ O caráter público versus o caráter privado de uma iniciativa deste tipo (no Brasil, por exemplo, é comum encontrar entidades de assistência social incomodadas com o sentimento de estarem fazendo algo que o Estado é que deveria estar fazendo); 
$\diamond$ A necessidade de controle, transparência e prestação de contas versus a demanda por liderança e responsabilidade fiduciária;

$\diamond \quad$ A busca de homogeneidade e harmonia versus a luta por preservar e manter um nível adequado de diversidade e diferenças de opinião;

$\diamond \mathrm{O}$ trabalho coletivo do conselho versus o desempenho e a consciência individualde cada conselheiro;

$\diamond$ A exigência de participação de membros e associados versus o benefício do povo (genericamente falando);

$\diamond$ A demanda por um comportamento comprometido e engajado do conselho versus a idealização de uma postura de isenção, distanciamento e visão global para a tomada de decisões;

$\diamond \mathrm{O}$ controle interno versus o controle externo das entidades;

$\diamond$ Um papel simbólico-político-legal dos dirigentes versus um papel técnico-funcional da liderança gerencial;

$\diamond$ A mediação do ambiente interno às organizações versus uma concentração em assuntos mais externos e ligados àcoletividade;

$\diamond$ O conselho sendo visto como um órgão de gestão versus o conselho visto como uma arena de exercício da cidadania.

Uma possível polaridade presente na maioria dos casos é a polaridade do ideal (ou do que quer vir a ser) versus o possível (o que é). Ela pode aparecer como uma das principais fontes de energia para o amadurecimento das formas de governança no terceiro setor.

Toledo (1999) ${ }^{41}$, um autor brasileiro, falando das sociedades anônimas, comenta que no Brasil a antiga Lei das Sociedades por Ações (Decreto-lei 2.627/40) adotava um sistema unitário, estabelecendo que a companhia seria administrada por seus diretores. Segundo ele, os adeptos desse posicionamento chamavam a atenção, principalmente, para 0 fato de que um segundo órgão de administração seria inoperante, oneroso e desnecessário. Toledo considera que este sistema correspondeu ao fenômeno da chamada revolução gerencial, que dava imenso poder aos administradores.

Apesar disso, era freqüente a criação de conselhos, nas maiores empresas, o que demonstrava a insuficiência do regime legal. Tais conselhos eram, no entanto, precipuamente consultivos...

A nova lei das sociedades anônimas, de 1976, previu já a adoção de um regime dualista, que estabelece uma distinção nítida entre os órgãos encarregados das atividades deliberativas e executivas.

${ }^{41}$ TOLEDO, P.F.C.S. O conselho de administração na sociedade anônima: estrutura, funções e poderes, responsabilidade dos administradores. $2^{\mathrm{a}}$ ed. São Paulo: Atlas, 1999. 


\subsection{EstÁGIOS DE DESENVOLVIMENTO}

A dinâmica da governança em organizações do terceiro setor é complexa, tanto devido à natureza da atividade de governar, quanto por estar inserida num conceito ainda recente e pouco preciso do terceiro setor. Observando-se o fenômeno do ponto de vista das organizações, percebe-se que elas são como seres vivos: mudam, diferenciam-se, transformam-se, evoluem, amadurecem œm o passar do tempo, em função da sua biografia. É de se supor que a compreensão do processo de desenvolvimento das organizações possa ajudar a entender melhor como se dão os mecanismos de governança em diferentes configurações institucionais.

Schaefer \& Voors (2000) ${ }^{42}$ descrevem um quadro geral das fases de desenvolvimento de uma iniciativa com o passar do tempo - este quadro, segundo eles, não tem a finalidade de negar o caráter único de cada entidade, mas de descrever os desafios e oportunidades características que existem no seu ciclo de vida. São três as fases típicas pelas quais passam as organizações, segundo esses autores: a fase pioneira, a fase de diferenciação e a fase de integração.

A fase pioneira caracteriza-se por uma forte busca por responder às necessidades e demandas externas, predominando para isso a improvisação. Nesta fase a liderança está centrada em um indivíduo ou grupo iniciador, que estão pessoalmente envolvidos com as atividades organizacionais. A organização é orientada às pessoas, sendo a comunicação pessoal e direta, porém com um processo decisório muitas vezes intuitivo - garantindo flexibilidade e capacidade de adaptação às mudanças no ambiente externo. Geralmente a motivação e o comprometimento com a organização pioneira são bastante altos, estando a maioria das metas e objetivos implícitos nas idéias e na personalidade do grupo carregador.

Vários fatores podem levar à crise da fase pioneira, entre os quais o crescimento das atividades e do tamanho da organização, a entrada de pessoas novas, novas estruturas de tomada de decisão, mudanças nas pessoas que exercem a liderança, etc. Alguns fenômenos são comuns nesta crise: perda de confiança na liderança, incerteza quanto a objetivos e rumos e necessidade de definição de responsabilidades e funções.

Superada a crise da fase pioneira, pode a organização adotar uma forma mais objetiva, racional e funcional para alcançar seus propósitos. Ocorre uma maior formalização da instituição nesta fase, percebida pela determinação explícita de p apéis, objetivos e normas, advindos de processos formais de planejamento. Esta fase requer, segundo aqueles autores: (a) uma renovação da identidade da iniciativa; (b) um novo entendimento dos papéis de liderança; (c) a construção de novas estruturas de funcionamento, com maior especialização funcional; e (d) uma mudança nos estilos de decisão e liderança. A organização terá, então, as seguintes características:

1. Tamanho maior;

2. Políticas e procedimentos mais claros;

3. Estruturas e mandatos diferenciados;

${ }^{42}$ SCHAEFER, C. \& VOORS, T. Desenvolvimento de Iniciativas Sociais: da visão inspiradora à ação transformadora. São Paulo: Antroposófica, 2000. 
4. Maior nível de profissionalização;

5. Liderança mais funcional do que pessoal;

6. Processo de decisão mais racional e analítico;

7. Maior clareza dos processos de trabalho.

A crise da fase de diferenciação costuma ser marcada pela perda de vitalidade, queda na motivação, altos níveis de absenteísmo e dificuldades contínuas de comunicação. Em pequenas organizações pode-se notar um apego ao passado, reuniões intermináveis, falta de objetivos e limitada inovação.

Uma organização madura, dizem Schaefer \& Voors, enfrentando uma crise da fase de diferenciação, necessita conscientemente entrar numa nova fase de seu desenvolvimento, optando por um novo conjunto de valores, uma orientação diferente às atividades e estruturas mais simples e descentralizadas. Isso significa formular novas metas e objetivos, simples e significativos, relacionados aos serviços essenciais oferecidos aos seus clientes. Nesta reformulação de metas está contida uma renovação das relações com parceiros e clientes, aproximando a organização daqueles a quem da serve. O processo de decisão é orientado por novos valores e critérios, levando em consideração o desenvolvimento da organização como um todo. Um elemento chave é o desenvolvimento de maior consciência do funcionamento e dos processos de trabalho da organização toda, por parte de cada indivíduo e equipe. Resumidamente, as características da fase de integração são:

1. Renovação do propósito central e dos valores da organização para prover sentido ...

2. Criação de órgãos para associação-diálogo consciente com parceiros, clientes, fornecedores e a comunidade na qual a iniciativa é ativa.

3. Um estilo de liderança e tomada de decisões que considera as necessidades humanas, explicitamente equilibrando critérios financeiros, técnicos e sociais; consciência não limita da àanálise racional.

4. Um maior entendimento dos seres humanos e a criação de processos de trabalho e estruturas que levam em consideração este entendimento das capacidades humanas.

5. Criação de uma organização orientada a processos, na qual as estruturas refletem as exigências dos processos centrais de trabalho ao invés de mecanismos de controle administrativo ....

6. Construção de equipes auto-dirigidas e menores, formas organizacionais descentralizadas e horizontais.

7. Pensamento horizontal e orientado aos processos, ao invés de vertical e hierárquico.

Apesar da simplificação em fases, Schaefer \& Voors consideram que o verdadeiro desenvolvimento é um processo descontínuo, irreversível, movendo-se de um estágio de crescimento através da diferenciação para um nível mais alto de integração e passando por crises que oferecem impulsos para a evolução. 
Para Adizes (1993) ${ }^{43}$, o crescimento e o envelhecimento das organizações manifestam-se primordialmente na inter-relação entre dois fatores: flexibilidade e controlabilidade.

As organizações quando são jovens são bastante flexíveis, mas nem sempre são controláveis. À medida em que as organizações envelhecem, essa relação se altera. A controlabilidade aumenta e a flexibilidade diminui.

Classificar uma organização como jovem é reconhecer sua capacidade de mudar com facilidade, ainda que - resultado da mudança seja relativamente imprevisível. Por outro lado, uma organização "velha" é controlável, mas com maior dificuldade para a mudança. O estágio em que a organização é ao mesmo tempo flexível e controlável é chamado por Adizes de "plenitude", considerando-se que crescer implica poder lidar com problemas maiores e mais complexos.

Envelhecer significa que há uma diminuição da capacidade de enfrentar problemas. Os mesmos problemas que uma organização vinha enfrentando há anos começam a parecer cada vez mais insuperáveis àmedida em que ela envelhece. É, no entanto, possível reverter o processo de envelhecimento.

Para lidar adequadamente com o processo de amadurecimento de uma organização, aquele autor propõe que é necessária a concentração naqueles problemas pertinentes ao estágio corrente da entidade. 0 quadro abaixo sintetiza as principais idéias de Adizes quanto ao ciclo de vida das organizações, adaptadas para organizações sem fins lucrativos:

\begin{tabular}{|c|c|}
\hline Organizações em crescimento & Organizações em envelhecimento \\
\hline Sucesso provém de assumir riscos & Sucesso provém de evitar riscos \\
\hline Expectativas excedem resultados & Resultados excedem expectativas \\
\hline Escassez de recursos & Abundância de recursos \\
\hline Enfatiza-se mais a função do que a forma & Enfatiza-se mais a forma do que a função \\
\hline De por que e oque ... & .... a como fazer e quem o fez \\
\hline $\begin{array}{l}\text { As pessoas são mantidas por suas } \\
\text { contribuições, a despeito de suas } \\
\text { personalidades }\end{array}$ & $\begin{array}{l}\text { As pessoas são mantidas por suas } \\
\text { personalidades, a despeito de suas } \\
\text { contribuições }\end{array}$ \\
\hline Tudo é permitido a menos que & Tudo é proibido a menos que \\
\hline $\begin{array}{l}\text { Problemas são vistos como } \\
\text { oportunidades }\end{array}$ & $\begin{array}{l}\text { Oportunidades são vistas como } \\
\text { problemas }\end{array}$ \\
\hline
\end{tabular}

${ }^{43}$ ADIZES, I. Os ciclos de vida das organizações: como e por que as empresas crescem e morrem e o que fazer a respeito. São Paulo: Pioneira, 1993. 


\begin{tabular}{|c|c|}
\hline Organizações em crescimento & Organizações em envelhecimento \\
\hline $\begin{array}{l}\text { Poder político está com as equipes } \\
\text { técnica e de captação de recursos }\end{array}$ & $\begin{array}{l}\text { Poder político está com os setores } \\
\text { jurídico, de contabilidade e finanças }\end{array}$ \\
\hline O pessoal de campo dita as regras & Os administradores ditam as regras \\
\hline $\begin{array}{l}\text { Responsabilidade não é contrabalançada } \\
\text { por autoridade }\end{array}$ & $\begin{array}{l}\text { Autoridade não é contrabalançada por } \\
\text { responsabilidade }\end{array}$ \\
\hline A gerência controla a organização & A organização controla a gerência \\
\hline A gerência controla o impulso & A gerência é controlada pela inércia \\
\hline $\begin{array}{l}\text { Mudanças na liderança podem levar a } \\
\text { mudanças no comportamento da } \\
\text { organização }\end{array}$ & $\begin{array}{l}\text { Muda nças no sistema são necessárias } \\
\text { para provocar mudanças no } \\
\text { comportamento da organização }\end{array}$ \\
\hline Consultores são necessários & "Insultores" são necessários \\
\hline De uma orientação para os serviços... & ...àpreocupação com os resultados \\
\hline De metas de valor adicionado... & ....̀̀s habilidades políticas \\
\hline
\end{tabular}

Estas referências sobre o desenvolvimento das organizações deixam pistas sobre como é a governança em cada fase, mas podese caracterizar mais precisamente as funções, papéis e comportamentos dos grupos dirigentes - especificamente os conselhos - em cada situação.

Lodi $(1988)^{44}$, numa análise do que acontece nas empresas, afirma que a história da mudança dos conselhos nos Estados Unidos ensina que é lenta a evolução de um conselho puramente estatutário para um conselho atuante.

Os conselhos maduros não são para quem quer, mas para quem pode.

Utilizando como parâmetro principal o tamanho, percebe-se que nas organizações pequenas o poder está normalmente concentrado na pessoa do fundador - havendo um conselho, compõe-se de amigos próximos ("figurantes") e reúne-se uma vez por ano, preenchendo necessidades legais. Num segundo estágio, este conselho já mantém reuniões regulares - trimestrais - sob muita informalidade, consistindo numa mistura de assuntos administrativos. Num terceiro estágio observa-se um início de profissionalização. As reuniões são mais intensivas, talvez até mensais, com uma agenda formal, separando os assuntos do conselho dos assuntos administrativos. Admite-se para o conselho uma tarefa diferenciada, diz Lodi. Porém, ainda há uma dominância do executivo principal e da equipe de direção.

Posteriormente, no quarto estágio, o conselho é dominado pelo "pessoal de dentro", mas com uma crescente participação de externos. As reuniões permanecem regulares, precedidas por informação dos principais pontos a serem discutidos. O conselho pode ser o responsável exclusivo por aprovar certos projetos e de tomar algumas decisões políticas. Já na grande empresa o conselho toma um aspecto

${ }^{44}$ LODI, J.B. Conselho de Administração. São Paulo: Pioneira, 1988. 
definitivo: há um bom número de conselheiros extemos, mantendo distância crítica da administração e adicionando uma "visão de fora"; as reuniões são regulares e formam-se comitês; os assuntos discutidos referem-se a objetivos, diretrizes, políticas e planejamento.

No que Lodi caracteriza como sexto estágio, a empresa tem o seu capital aberto e pulverizado; observa-se extensa atividade do conselho e grande delegação a comitês; há predominância de representantes externos àadministração e de acionistas.

Apesar da descrição adequar-se restritamente às organizações com fins lucrativos, nota-se uma direção similar à descrita por Schaefer \& Voors. O estudo destes processos de mudança e evolução dos conselhos em empresas trouxe algumas lições para Lodi:

- Não se pode exigir maturidade de uma criatura que está nas cendo;

- Em alguns casos, o executivo principal pode encontrar-se demasiado ocupado com as operações para poder usar o conselho na amplitude e freqüência desejada;

- No início, pode haver dificuldade para encontrar bons conselheiros, devido à falta de experiência anterior;

- O conselho pode ser considerado, no começo, um experimento educacional incipiente, cujo aprendizado demanda tempo;

- Começar num nível menos complexo, evitando grande número de conselheiros e restringindo suas atribuições (e expectativas em relação a eles) pode ser mais prudente.

Voltando às organizações da sociedade civil, Hudson (1999) caracteriza quatro fases no ciclo de evolução dos conselhos: fase de fundação, fase jovem, fase adulta e fase madura. As características principais de cada fase são:

(a) Fase de fundação - existe uma liderança que identificou um problema social e resolveu criar uma organização para encaminhálo. Esta liderança reuniu um grupo de pessoas (o conselho, ou qualquer outro nome que se queira dar) que partilha das mesmas idéias e comprometeurse com a iniciativa, assumindo o papel também de executoras, além de dirigentes. A contratação de pessoal freqüentemente provoca a primeira crise deste conselho, exigindo diferenciar seu papel.

(b) Fase jovem - a organização cresceu e já conta com uma equipe de administração, que assume responsabilidade pela maior parte do trabalho. O conselho pode ficar em segundo plano, tornando-se as reuniões rotineiras e as discussões menos intensas - a freqüência diminui e o respeito pela sua existência declina - até que sobrevenha uma crise forçando o conselho a reavaliar seu papel.

(c) Fase adulta - a reavaliação do papel do conselho pode levar à conclusão de que ele precisa de pessoas com maiores habilidades profissionais. Estas pessoas quando se agregam g eralmente trazem consigo um novo conjunto de atitudes, que por vezes dificulta o relacionamento e acaba por provocar o distanciamento de alguns membros antigos. O conselho com estes novos participantes se propõe a estabelecer objetivos, avaliar o desempenho da entidade e administrar o orçamento - sob o risco de desconectar-se da missão original da entidade. É comum ocorrer uma necessidade de entender 
detalhes da organização, reunir mais freqüentemente e formar comissões. Uma crise pode advir se o conselho começar a imiscuir-se demasiadamente nos assuntos da equipe administrativa.

(d) Fase madura - nesta fase o conselho adota uma postura de menor interferência, preocupando-se mais em recrutar novos membros, geralmente de prestígio, que vêm com pouca propensão a envolver-se em detalhes. Se as reuniões tornam -se rotineiras, o quadro se estabiliza e volta-se a praticar os velhos e maus hábitos - pode se irromper uma crise, voltando a um estágio anterior de desenvolvimento.

Ter em mente o estágio antigo e o novo é uma ferramenta poderosa ao ajudar as pessoas a relacionarem-se com o problema e a encontrarem caminhos promissores que sejam aceitos pela maioria.

Todas estas discussões vão indicando que o conselho não pode ser estático, devendo evoluir àmedida que a organização se desenvolve, a fim de corresponder aos novos desafios que enfrenta. Um estudo americano realizado por Mathiasen $(1996)^{45}$ identificou três estágios importantes na vida do conselho diretor de uma organização sem fins lucrativos. O pressuposto do autor, porém, é de que o processo de evolução pode não ocorrer naturalmente, os conselhos podem não necessariamente passar por todos os estágios e a transição de um tipo para outro pode ser incerta e difícil.

O primeiro estágio caracterizado por Mathiasen é o do conselho organizador. Neste estágio o conselho pode assumir duas formas: (a) conselho seguidor ou (b) conselho orientador ou dominador.

Os conselhos (organizadores) seguidores geralmente são pequenos, muitas vezes porque o líder é quem convida os consel heiros e não precisa ou não quer um conselho grande... Esses conselhos tendem a ser homogêneos, pois se compõem de pessoas que o líder conhece bem ... as reuniões e as relações tendem a ser informais e os conselheiros se contentam em ouvir relatórios das atividades, prestar assessoria e incentivar.

O conselho organizador seguidor tem como tarefa principal dar apoio à liderança que mostra forte compromisso com a missão da organização, não desenvolvendo um senso de propriedade muito intenso, nem um papel significativo no levantamento de recursos. Por outro lado...

\section{Conselhos organizadores dominadores ... em sua maioria são compostos por "guerreiros" que se juntam para dedicar tempo e energia a uma causa com a qual mantêm um forte compromisso. ... podem ser pequenos no início e bastante homogêneos, compostos de pessoas dispostas a realizar quaisquer tarefas necessárias para manter a organização funcionando.}

Estes conselhos organizadores dominadores orientam-se para as tarefas e têm a organização como sua, podendo desempenhar papel importante na captação de recursos. Estando tão ligado ao dia-a-dia e por

\footnotetext{
${ }^{45}$ MATHIASEN III, K. A evolução dos conselhos: três estágios importantes na vida do conselho diretor de uma organização sem fins lucrativos. Tradução de Eduardo Marino. Washington, D.C.: National Center for Nonprofi Boards, 1996.
} 
compor-se de um grupo bastante coeso, este tipo de conselho pode demorar a aceitar a contratação de funcionários ou a entrada de novos conselheiros.

Conforme aumenta a complexidade da organização, os conselhos dominadores e seguidores eventualmente percebem a necessidade de mudar e de agir mais como "conselhos", compartilhando a liderança com a equipe técnica e exigindo papéis mais claros, novos sistemas e "atitude mais empresarial".

O segundo estágio apresentado por Mathiasen é o do conselho dirigente. Sua principal característica é assumir a direção da organização e deixar as tarefas operacionais para a equipe técnica. Há uma divisão de poder entre ambos, o conselho e a equipe técnica. Estes conselhos tendem a ser mais diversificados e maiores, surgindo comitês. Em geral, a equipe técnica aceita reportar-se ao conselho e este aceita assumir maior responsabilidade por assegurar à organização os recursos de que ela necessita. Este conselho pode demandar um grande esforço do principal executivo da organização, especialmente no início, sendo comum os resultados não surgirem imediatamente.

Se a liderança na organização ... for forte e realmente atuar para introduzir mudanças, o conselho pode desenvolver uma nova dinâmica dentro de três anos, provavelmente não antes disso. Quando os líderes decidem que o conselho deve mudar, podem sentir-se frustrados ao constatar que se trata de um processo gradual. O conselho parece ser a parte da organização que mais tempo leva para mudar e se adaptar a uma nova dinâmica. Esse atraso não se deve à incapacidade ou deficiência dos conselheiros, mas geralmente ao fato de que o conselho é a parte da organização àqual os líderes dedicam menos atenção, principalmente no estágio inicial.

Com o aumento da demanda intra e extra organização, o conselho pode evoluir para um terceiro estágio: o do conselho institucional. O conselho institucional geralmente é grande, diversificado e inclui mais pessoas que podem doar ou têm acesso a doadores, adquirindo maior prestígio. Este conselho comumente aceita a função de captar recursos e delega a gestão a um comitê executivo. Outros tipos de atividades ocupam grande parte do trabalho feito pelos comitês, dos quais o conselho passa a depender cada vez mais.

Um conselho maduro supõe que o quadro profissional e cada vez mais sofisticado da equipe técnica seguirá os planos aprovados e administrará a organização de maneira responsável. ... Contudo, é imperativo que um comitê executivo ou de auditoria - ou ambos - supervisione o trabalho da equipe técnica e examine periodicamente as finanças da organização.

Ostrowski (1989) ${ }^{46}$ reconhece que um grande número de organizações sem fins lucrativos está num estágio inicial ou juvenil no seu ciclo de vida, no qual os papéis do conselho são diferentes daqueles das organizações mais maduras. Segundo ele, o equilíbrio entre as funções do conselho e da equipe técnica ou administrativa é diferente para cada organização, dependendo do seu estágio de desenvolvimento e tradição histórica.

${ }^{46}$ OSTROWSKI, M. Nonprofit Boards of Directors. In: GIES, D.L., OTT, J.S. \& SHAFRITZ, J.M. The nonprofit organization: essential readings. Belmont: Wadsworth Publishing Company, 1990. 
Cinco são, entretanto, as fases pelas quais passa uma entidade sem fins lucrativos, de acordo com Ostrowski, sintetizadas no quadro abaixo:

\begin{tabular}{|c|c|c|}
\hline Fase & Características da organização & Características do conselho \\
\hline Fase Um & $\begin{array}{l}\text { Um indivíduo ou grupo concentram o } \\
\text { talento, a energia e o carisma da } \\
\text { organização; } \\
\text { Alto grau de criatividade e } \\
\text { comprometimento; } \\
\text { Informalidade, voluntarismo, trabalho } \\
\text { intenso e salários baixos; } \\
\text { Organizações pequenas, dependentes do } \\
\text { carisma das suas lideranças. }\end{array}$ & $\begin{array}{l}\text { O conselho é a organização; } \\
\text { Não há diferenciação entre papel } \\
\text { administrativo e papel diretivo; } \\
\text { O "conselho" faz de tudo, tipo "mãos à } \\
\text { obra". }\end{array}$ \\
\hline 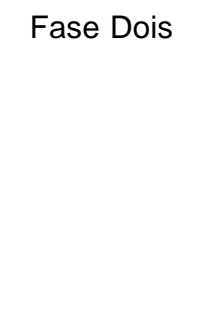 & $\begin{array}{l}\text { Existe uma equipe técnica diferenciada; } \\
\text { As funções estão definidas e } \\
\text { diferenciadas; } \\
\text { Há procedimentos contábeis e financeiros } \\
\text { determinados; } \\
\text { Comunicação formal e mais impessoal; } \\
\text { Gestão profissional. }\end{array}$ & $\begin{array}{l}\text { Suas atribuições são: determinar políticas } \\
\text { de pessoal, envolver-se na escolha de um } \\
\text { contador, envolver-se em auditorias } \\
\text { anuais, dar atenção geral ao crescimento } \\
\text { da organização; } \\
\text { Papel de "aprovador". }\end{array}$ \\
\hline Fase Três & $\begin{array}{l}\text { Descentralizada, com gerentes de } \\
\text { programas e projetos; } \\
\text { Planejamento orçamentário; } \\
\text { Maior autonomia para os colaboradores; }\end{array}$ & $\begin{array}{l}\text { Diversificado; } \\
\text { Descentralização através de comitês; } \\
\text { Envolvimento de consel heiros em certos } \\
\text { projetos. }\end{array}$ \\
\hline Fase Quatro & $\begin{array}{l}\text { Coordenação é a tarefa chave: quanto } \\
\text { melhor, menor a fragmentação; } \\
\text { Decisão centralizada, considerando a } \\
\text { organização como um todo; } \\
\text { Maior distância entre níveis } \\
\text { organizacionais. }\end{array}$ & $\begin{array}{l}\text { Maior grau de integração entre projetos } \\
\text { separados e entre comitês consultivos no } \\
\text { conselho como um todo; } \\
\text { Orientações mais estruturadas; } \\
\text { Retiros de conselheiros focando na } \\
\text { missão da organização. }\end{array}$ \\
\hline Fase Cinco & $\begin{array}{l}\text { Cultura colaborativa; } \\
\text { Ação em equipe, forças tarefas } \\
\text { integradas; } \\
\text { Organização matricial, decisões } \\
\text { colegiadas; } \\
\text { Responsabilidades diferenciadas: o } \\
\text { conselho concentra-se na determinação } \\
\text { de diretrizes; a equipe executiva } \\
\text { geralmente trabalha na administração, } \\
\text { gestão e implementação dos programas }\end{array}$ & $\begin{array}{l}\text { Equilíbrio entre supervisão e definição de } \\
\text { diretrizes; } \\
\text { Retiros de instrução e planejamento; } \\
\text { Interação positiva com equipe técnica e } \\
\text { administrativa; } \\
\text { Relações flexíveis e saudáveis entre } \\
\text { conselho e gestores; }\end{array}$ \\
\hline
\end{tabular}

O trabalho de Andersson (1999) ${ }^{47}$, da África do Sul, analisa como o conselho pode contribuir durante três fases típicas do desenvolvimento das organizações. Na fase pioneira, o conselho pode ser composto pelos fundadores, tendendo a ser orientado à ação e diretamente responsável pela captação de recursos. Caso o conselho seja composto por pessoas convidadas pela liderança carismática, vai se limitar a ouvir e comentar a respeito das atividades da organização, concentrando sua ação em apoiar os carregadores.

${ }^{47}$ ANDERSSON, G. The governance of changing organisations - first draft. Mimeografado. Jo hannesburg: Development Resources Centre, 1999. 
Na fase "racional" (ou de diferenciação), o conselho pode ser colocado "no alto da pirâmide", sob o argumento de que sua tarefa é a determinação de diretrizes.

Boa parte da nossa noção de governança muitas vezes deriva desta imagem de conselho e a ela atribui-se a alocação rígida de uma função diretiva ao conselho. Paradoxalmente, muitos conselhos são reféns do executivo na determinação de políticas; eles respondem a relatórios situacionais e documentos diretivos, sendo conduzidos nesta função diretiva assim como um departamento é gerenciado para alcançar seus objetivos.

Mesmo conselhos que conseguem ser proativos na fase racional freqüentemente se estabelecem através de comitês, que dão atenção a assuntos específicos da vida organizacional. No caso de conselhos institucionais (tal como definidos por Mathiassen), eles se tornam ativamente envolvidos em captação de recursos, confiando na delegação de responsabilidades a um comitê executivo.

$\mathrm{Na}$ fase de integração o conselho não é mais visto no topo de uma pirâmide, mas parte de um processo de governança na qual inovação e desenvolvimento são temas íntimos. O conselho, ativo e engajado, é visto como figura central, se tornando um local para encorajamento, questionamento e suporte - e governança é entendida como uma função compartilhada.

\section{Cada caracterização do comportamento do conselho numa fase particular de desenvolvimento corre o risco de se tornar uma caricatura, uma vez que ela depende substancialmente da composição de pessoas naquele momento e das suas dinâmicas interpessoais. A 'mágica' de alguns conselhos ... reside na interação sinérgica de indivíduos com uma diversidade de experiências e com pontos de vista sutilmente diferentes. Isso acontece somente se existe uma orientação comum a respeito da missão e dos valores da organização.}

Em praticamente todas as descrições pode-se perceber, mais uma vez, porém sob um ângulo diferente, que o processo de governança de uma organização é permeado por tensões e as reações a elas. Estas tensões advêm de posições polares entre:

$\diamond \quad$ um papel de apoiador versus um papel de carregador;

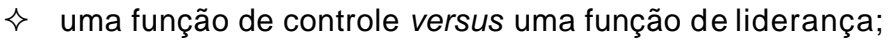

$\diamond \quad$ uma postura passiva versus uma postura proativa;

$\diamond$ um vínculo frio, distanciado versus um senso de propriedade e engajamento;

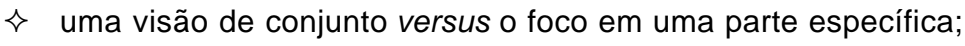

$\diamond \quad$ a ação coletiva versus a iniciativa individual;

$\diamond \quad$ uma necessidade de centralização versus uma necessidade de descentralização;

$\diamond \quad$ um perfil homogêneo versus um perfil heterogêneo;

» uma contribuição mais técnica versus uma contribuição mais simbólica;

$\diamond \quad$ um olhar de dentro para fora versus um olhar de fora para dentro; 
$\diamond$ uma preocupação maior em consolidar versusum impulso dinamizador.

A identificação e explicitação destas tensões - aparentemente sempre presentes, em maior ou menor grau pode contribuir para que aquelas pessoas envolvidas nos processos de governança de organizações da sociedade civil possam realizar melhores diagnósticos e intervenções conscientes que visem 0 desenvolvimento das instituições em que estão.

\subsection{DISTINÇÕES A RESPEITO DO SISTEMA ORGANIZACIONAL}

O conhecimento das raízes históricas da existência de conselhos e dos estágios de desenvolvimento por que passam organizações permitem ter noção da dinâmica de evolução destas entidades. Este conhecimento de processo, entretanto, precisa ser complementado com outros conhecimentos de estrutura e, quem sabe, de resultados - com o fim de formar um grande arcabouço a respeito da finalidade, utilidade, desempenho, funções, responsabilidades, etc. dos conselhos que atuam nas organizações da sociedade civil e da sua governança.

Algumas distinções a respeito da estrutura de governança carecem de ser realizadas, respondendo a questões do tipo: "Qual a diferença conceitual (não contextual) entre conselho e diretoria? Por que algumas organizações têm um conselho e uma diretoria e outras não? Que tipo de referências podem ajudar a ter maior clareza do papel dos diferentes órgãos relacionados à governança das organizações da sociedade civil? Que tipos de liderança estão relacionados ao processo de governança?" Estas perguntas são especialmente relevantes no contexto brasileiro, de instituições relativamente pequenas vivendo um processo intenso de profissionalização.

O primeiro passo consiste em explorar o conceito de sistema organizacional.

Segundo Lievegoed (1991) ${ }^{48}$, a palavra sistema significa coerência entre diversos componentes, representando uma totalidade de elementos, conceitos ou variáveis selecionados pelo homem. Pode-se dizer a respeito dos sistemas:

- Todo sistema é parte de um sistema maior: seus limites (e suas variáveis) são definidos de acordo com as questões e problemas existentes;

- Todo sistema é uma simplificação da realidade: para manter uma visão mais ou menos clara de um sistema faz-se obrigatório algum tipo de seleção - a representação de um sistema será apenas uma parte da realidade;

- A habilidade de continuar a existir a despeito de adaptações necessárias a um ambiente em mudança é chamada de identidade de um sistema: um sistema pode ter uma identidade forte ou fraca e a total perda de identidade leva àdesintegração do sistema;

\footnotetext{
${ }^{48}$ LIEVEGOED, B.C.J. Managing the developing organization: tapping the spirit of Europe. Cambridge: Basil Blackwell, 1991.
} 
- Pode-se falar não somente da identidade, mas também do potencial de um sistema: os sistemas vivos carregam em si um certo potencial que os possibilita manifestar sua identidade própria através de várias metamorfoses;

Entidades sociais, como associações ou empresas, também podem ter identidades fortes ou fracas e maior ou menor potencial de desenvolvimento futuro.

- Um sistema compõe-se de níveis de organização: nesta hierarquia, cada nível contém todos os níveis sob ele e adiciona uma nova dimensão que não estava incluída em níveis inferior es;

- Quanto mais alto o nível de organização dentro de um sistema, maior o grau de diferenciação e complexidade.

Nesse caminho de desenvolvimento do sistema, um padrão de mudança progressiva na estrutura - que vai tomando espaço durante toda a história de vida da entidade - pode ser reconhecido:

No começo, todas as funções estão implícitas e não ainda diferenciadas; mais tarde, subsistemas especializados são criados através da diferenciação; e finalmente, através da integração, todos estão orientados para um objetivo comum, enquanto cada indivíduo exerce sua tarefa especializada sabendo que os outros estão exercendo as suas e que o resultado desejado pode ser alcançado somente se houver um esforço concentrado.

Diferenciar, neste conceito, diz respeito a distinguir, discriminar, significando que cada estágio de desenvolvimento subseqüente é mais complexo do que o anterior e implica a criação de subsistemas especializados. Essa diferenciação ocorre em função de pelo menos três tendências:

(a) um crescimento na escala de entidades sociais - todo crescimento em quantidade, entretanto, chega a um limite além do qual mudanças estruturais são necessárias para que aquela entidade permaneça viva;

(b) o aumento na complexidade de todas as estruturas sociais - isto ocorre porque as necessidades das entidades sociais que crescem são mais diversificadas;

(c) uma aceleração de todos os desenvolvimentos - uma situação torna -se explosiva quando atinge pontos críticos em muitos campos ao mesmo tempo, suscitando um sentimento generalizado e crônico de insegurança.

KAPLAN (1996) ${ }^{49}$ afirma que a diferenciação e a formação de órgãos (subsistemas) são aspectos inerentes a processos de desenvolvimento, por meio dos quais funções inicialmente realizadas pelo sistema como um todo se concentram daí por diante em subsistemas, de modo mais efetivo. Este desenvolvimento gera maior grau de complexidade do sistema conforme diferenciam-se mais subsistemas, que têm que trabalhar juntos para que manter o adequado funcionamento de todo o organismo. A evolução do sistema acarreta, portanto, a separação de sistemas simples (ou organismos) em uma variedade complexa de subsistemas

${ }^{49}$ KAPLAN, A. The development practitioners' handbook. Chicago: Pluto Press, 1996. 
mais especializados - um processo que se move do simples para o complexo, do homogêneo para o heterogêneo. O risco da diferenciação é que subsistemas especializados começam a operar independentemente uns dos outros levando ao detrimento do sistema como um todo.

No movimento de desabrochar da vida, a seqüência padrão parece ser divisão

(diferenciação), seguida de organização (hierarquização), seguida por coesão ou coerência (integração) num novo nível ou forma.

Lievegoed explica a importância do pensamento sistêmico para a administração: é possível descrever um sistema organizacional como sendo composto por subsistemas - o desafio da gestão é integrar estes subsistemas dentro da organização.

Considerando a organização como um sistema, Large $(1981)^{50}$ consegue identificar três subsistemas predominantes, funcionalmente distintos e dependentes, para o seu desenvolvimento, de diferentes princípios:

- Subsistema Técnico*: compreende todas as idéias, leis científicas, métodos, procedimentos e técnicas que fundamentam os produtos e serviços prestados pela organização. O desenvolvimento deste subsistema é dependente de um tipo específico de consciência, que é profissional, criativa, orientada æ̀s idéias, baseada em pesquisas e científica. Esta consciência orientada é utilizada por cada membro da organização ao utilizar uma habilidade particular, um treinamento, talento ou prática.

As técnicas e idéias têm sido desenvolvidas e incorporadas como inovações na tecnologia e funcionamento dos serviços.

- Subsistema Social: consiste no conjunto de todas as relações entre as pessoas, grupos e departamentos e na forma pela qual as pessoas decidem as regras, normas e procedimentos que vão organizar técnicas novas e tradicionais. Neste sistema desenvolve-se, pelo modo que as pessoas reúnem-se para decidir sobre regras formais e informais de trabalho, um tipo de consciência social.

Pessoas diferentes - especialistas, coordenadores ou colaboradores - têm diferentes responsabilidades e direitos nas diversas áreas e acordos e arranjos são criados, dissolvidos e alterados com o passar do tempo.

- Subsistema Econômico: nesta terceira área estão os objetivos primordiais de uma insti tuição e todas as situações relacionadas à satisfação de necessidades de um conjunto de clientes. Apropriada a este subsistema é um tipo de consciência orientado ao serviço e ao alcance de objetivos externos à organização.

${ }^{50}$ LARGE, M. Social Ecology: exploring post industrial society. Gloucester (Inglaterra): Martin Large, 1981.

* Large utiliza o termo "subsistema cultural", ressaltando que: "Uma vez que os valores, modos de comportamento, normas e a atmosfera social são chamados freqüentemente de cultura organizacional, o conceito de subsistema cultural necessita ser diferenciado. Alguns autores, como Lievegoed, preferem chamar o subsistema cultural de uma organização de sistema técnicơ. Desse modo optou-se por utilizar o termo "subsistema técnico" para evitar confusões. 
A meta é prover serviços econômic os àqueles fora da organização e em todos os estágios a produção de bens ou a prestação de serviços é dirigida àsatisfação de necessidades.

Cada organização, portanto, mantém inter-relações dinâmicas entre os subsistemas técnico, social e econômico. Entretanto, se o equilíbrio entre estes subsistemas é perturbado, então um subsistema, junto com a forma de consciência que lhe é inerente, tende a predominar em detrimento da organização como um todo.

\begin{abstract}
Uma das tarefas daqueles trabalhando em organizações é tentar cultivar cada forma de consciência no subsistema relevante e balanceá-las de forma que os objetivos da organização possam ser adequadamente alcançados.
\end{abstract}

Os três aspectos citados do sistema organizacional podem ser mais facilmente distinguidos com o uso de três questões propostas por Large, relativas aos três subsistemas respectivamente:

1. Esta função está primariamente relacionada com um particular tipo de trabalho?

2. Esta função está primariamente relacionada com um particular grupo de pessoas?

3. Esta função está primariamente relacionada com um particular projeto ou demanda?

Obviamente, na prática as situações envolvem todas estas áreas, exigindo atenção para discernir qual é a mais relevante e onde os limites são ultrapassados entre áreas apropriadas para pro fissionais, líderes sociais e gestores.

Drucker $(1984)^{51}$, num livro básico sobre administração, apresenta isso de uma outra forma:

Três tarefas - igualmente importantes mas essencialmente diferentes entre si colocam-se diante da administração de toda organização:

a) meditar demoradamente na finalidade e missão específicas da entidade (tratese de empresa privada, de hospital ou de universidade) e especificá-las;

b) fazer com que o trabalho seja produtivo e o trabalhador se realize;

c) conduzir as repercuss ões sociais e as responsabilidades sociais da organização.

Essas podem ser ditas as dimensões da administração.

Houle (1989) ${ }^{52}$ oferece um conceito tão simples quanto essencial que contribui no encaminhamento das perguntas feitas no início desta seção. Segundo ele, na maioria das organizações da sociedade civil alguma

\footnotetext{
${ }^{51}$ DRUCKER, P.F. Introdução à administração. São Paulo: Pioneira, 1984.

${ }^{52}$ HOULE, C.O. Governing Boards: their nature and nurture. San Francisco: Jossey Bass, 1997.
} 
forma de um sistema tripartite relacionado à liderança toma efeito e a unidade deste sistema é mantida por um senso de missão. Mesmo em situações simples e diretas, entretanto, pode ser feita uma diferenciação entre três tipos de atividade:

(a) o trabalho a ser feito;

(b) a administração deste trabalho;

(c) e o estabelecimento de diretrizes para guiá-lo.

Conforme o tempo passa e a instituição cresce, a distinção entre os três se torna mais pronunciada. O conselho eventualmente precisa de uma equipe executiva para realizar os serviços e, quando essa equipe se multiplica, um gestor é necessário para coordenar e dirigir suas atividades. Algumas vezes este sistema tripartite é construído de outras maneiras do que simplesmente pelo crescimento em tamanho...

Todas as três partes deste sistema precisam estar entrosadas - não são entidades separadas colaborando mutuamente, mas partes de um mesmo todo integrado que não existiria se não houvesse uma razão maior. Dificuldades na integração deste conjunto podem ser causadas por interpretações diferentes desta razão de ser.

É interessante notar que não há, a princípio, hierarquia entre os três subsistemas, uma vez que nenhum é mais importante do que o outro. O surgimento de hierarquia formal pode representar meramente uma tentativa humana de manter controle sobre o sistema maior.

Numa caracterização dos tipos de liderança que podem ocorrer numa organização em desenvolvimento, HAETINGER (1997) ${ }^{53}$ menciona uma liderança constiticional, que estabelece objetivos e princípios, uma liderança organizacional, "no meio", e uma liderança "supervisora", na "linha de frente" dos serviços.

Com base em toda essa reflexão, podese extrair algumas considerações:

I- Pode-se falar sobre a existência de um sistema de governança, que tem pelo menos duas dimensões: uma interna àorganização e outra externa àorganização;

II - O sistema interno à organização é composto por pelo menos três subsistemas, mais ou menos diferenciados de acordo com o estágio de desenvolvimento da organização;

III - Os três subsistemas internos à organização podem ser denominados técnico, social e econômico cada um segue leis próprias e pressupõe a aplicação de um tipo diferente de consciência;

IV - A liderança organizacional pode ser de diferentes tipos e refletir um vínculo primário a um destes subsistemas;

V - O grau de diferenciação entre os três subsistemas pode levar à formação de dois ou mais órgãos, formais ou informais, dentro da organização;

${ }^{53}$ HAETINGER, H. Leis e fases na evolução das organizações. Mimeografado. São Paulo, 1997. 
VI - Cada órgão nos subsistemas internos possui uma identidade própria, mais forte ou mais fraca em função de diversos fatores, como a biografia da organização, o perfil das pessoas que dele fazem parte, o contexto em que se inserem, a missão da organização, etc.;

VII - Cada órgão nos subsistemas tem um potencial próprio que leva à determinação da forma em que se manifesta nas diversas situações práticas;

VIII - Geralmente, em organizações jovens e menores há um baixo nível de diferenciação entre os órgãos representativos dos subsistemas citados, enquanto que nas organizações maiores e mais maduras o nível de diferenciação é maior;

IX - Os limites entre a atuação dos órgãos representativos dos subsistemas é impreciso e pouco tangível, exigindo a revisão dos papéis conforme vão se desenrolando novas situações práticas;

$X$ - A relação da organização com seu ambiente externo pode influenciar a estruturação interna e a atuação de cada instância de liderança organizacional.

\subsection{O CONCEITO DE GOVERNANÇA INSTITUCIONAL}

Tendo desenvolvido a perspectiva do terceiro setor, da história das formas de governança, do processo de evolução das organizações e da estruturação do sistema organizacional, é possível construir e clarificar um conceito de governança institucional.

As definições encontradas no dicionário ${ }^{54}$ são:

Governar - (a) Regular o andamento de, conduzir, dirigir; (b) exercer sobre um país ou região o poder político, em especial o Executivo; (c) gerir, administrar; (d) exercer poder sobre, dominar; (e) ter poder ou autoridade, regular.

Governo - (a) Ato ou efeito de governar; (b) domínio, controle; (c) administração, direção; (d) Em um Estado, conjunto dos organismos e das pessoas que exercem o Poder Executivo; (e) sistema político de um Estado; (f) período em que alguém governa; (g) regulamento, orientação, norma, regra; (h) comando, controle.

Para Andersson (1999) ${ }^{55}$, uma definição operacional de governança tem duas partes: (a) sustentar e exercer autoridade (fornecida pelo Estado, pelos membros da organização e por apoiadores e beneficiários); e (b) ser responsável e prestar contas da atuação da entidade. Essa definição facilita o reconhecimento dos elementos da governança, mas provê, segundo ele, pouca informação a respeito do seu processo. Assim, ele adiciona que o processo de governança inclui o alcance de três grandes áreas, cuja coerência e equilíbrio afetam a sustentabilidade de uma entidade:

${ }^{54}$ LOVISOLO, E., PEREIRA, B.H.A. \& POZZOLI, T.C. Larousse Cultural: Dicionário da Língua Portuguesa. São Paulo: Nova Cultural, 1992.

${ }^{55}$ ANDERSSON, G. The governance of changing organisations - final draft. Mimeografa do. Washington D.C.: National Center for Nonprofit Boards, 1999. 
a) O papel da organização no macro ambiente: a determinação e fortalecimento do propósito organizacional (missão), das audiências a que ela serve e dos vínculos que mantém com outras organizações (seja através de redes ou parcerias);

b) As escolhas estratégicas da entidade e o impacto dos seus programas: a forma como são afetados a comunidade e os principais interessados na organização;

c) A aprendizagem e a saúde organizacional: a sólida construção dos sistemas organizacionais e sua capacidade, incluindo o desenvolvimento das pessoas que compõem a equipe executiva.

Assim, a governança, entendida como um sistema, sucede pela interação de vários fatores ou agentes, em diferentes instâncias e momentos. Num instante um determinado fator pode ser dominante; num outro momento um outro agente pode exercer maior influência. Entre estes fatores ou agentes pode-se mencionar:

- A atuação do conselho e/ou da diretoria;

- A realização de auditoria externa e a elaboração de relatórios anuais;

- A discussão com audiências chave da organização;

- O desempenho da equipe executiva;

- O escrutínio pela mídia;

- A contribuição de avaliadores externos;

- Os processos de auto-avaliação e aprendizagem interna.

Tandon \& George (1999) ${ }^{56}$ apresentam governança como sendo um conjunto de mecanismos, centrados no conselho ou diretoria, que visam exercer cinco funções essenciais relacionadas àligação entre a operação de uma organização voluntária e a sociedade:

i. Assegurar uma gestão financeira e um planejamento eficaz de atividades, de acordo com as exigências legais e estatutárias;

ii. Conservar os valores éticos e morais que inspiram a formação da entidade, de modo que ela possa agir de modo exemplar na sociedade;

iii. Fornecer uma visão de futuro e uma base filosófica que oriente a atuação institucional;

iv. Determinar diretrizes de funcionamento organizacional;

v. Prestar contas sobre o exercício das quatro funções anteriores.

Governança também pode ser entendida como a função de supervisão e administração que toma lugar quando um grupo de pessoas reúne-se para criar uma associação legal com fins não lucrativos (Gies et alli,

${ }^{56}$ TANDON, R. \& GEORGE, V. Governance of Voluntary Development Organizations. India: Institutional Development Journal, vol. VI nr. I, 1999. 
1990) ${ }^{57}$; supervisão essa que acontece dentro de um paradigma legal e ético. O termo genérico governança refere-se ainda, segundo estes autores, às ações coletivas de um grupo de diretores ou curadores na direção de organizações com direito a isenções fiscais. Num nível mais amplo, entretanto, governança é a supervisão da atividade organizacional a partir de padrões éticos e legais.

Isto é difícil de ser alcançado; na verdade, é supremo para organizações sem fins lucrativos.

A palavra governança, segundo Lakey $(2000)^{58}$ tem origem na palavra grega kebernon, que significa pilotar, e o uso atual do verbete governar refere-se a dirigir, controlar e influenciar a partir de uma posição de autoridade. Para aquele autor, governança refere-se à distribuição legítima de autoridade em um sistema, seja um país ou uma organização - essa outorga de autoridade pode vir de uma variedade de fontes (desde sócios da entidade até funcionários públicos) e está também associada a parâmetros explícitos ou implícitos.

Governança é um complexo fenômeno de grupo. Governança não é simplesmente, e nunca poderá ser, uma ciência. Governar uma organização sem fins lucrativos é uma arte. (Widmer, 2000) ${ }^{59}$

Carver (1997) ${ }^{60}$ entende governança como um processo, baseado em liderança estratégica, que tem como um de seus produtos principais a determinação de propósito para um conjunto de pessoas e organizações.

Ainda, a governança pode ser entendida a partir de um ponto de vista formal, hierárquico, mas este traz uma contribuição restrita, de acordo com Holland \& Hester $(2000)^{61}$. A governança deve ser conceituada, sob um ponto de vista funcional, como um esforço colaborativo de diferentes atores ou lideranças em relação a uma visão de futuro.

SILVA $(2000)^{62}$ caracteriza a tarefa de dirigir uma organização como sendo contínua, dinâmica, diversificada, complexa e difícil de ser compreendida no seu conjunto, qualidades estas que podem ser consideradas inerentes ao processo de governança. Neste processo, quatro grandes "campos de força"

${ }^{57}$ GIES, D.L., OTT, J.S. \& SHAFRITZ, J.M. The nonprofit organization: essential readings. Belmont: Wadsworth Publishing Company, 1990.

${ }^{58}$ LAKEY, B.M. Nonprofit governance: steering your organization with authority and accountability. Washington D.C.: National Center for Nonprofit Boards, 2000.

${ }^{59}$ WIDMER, C.H. \& HOUCHIN, S. The art of trusteeship: the nonprofit board member's guide to effective governance. San Francisco: Jossey-Bass, 2000.

${ }^{60}$ CARVER, J. Boards that make a difference: a new design for leadership in nonprofit and public organizations. $2^{\text {nd }}$ ed. San Francisco: Jossey Bass, 1997.

${ }^{61}$ HOLLAND, T.P. \& HESTER, D.C. Building effective boards for effective religious organizations: a handbook for trustees, presidents and church leaders. San Francisco: Jossey-Bass, 2000.

${ }^{62}$ SILVA, A.L.P. Utilizando o planejamento como ferramenta de aprendizagem. São Paulo: Global, 2000. 
atuam continuamente afetando a sustentabilidade da organização: a sociedade, as pessoas interessadas dentro da organização, os serviços da instituição e os recursos àdis posição, incluindo o meio ambiente.

Em síntese, governança institucional pode ser entendida, de modo amplo, como:

1. Um processo contínuo que determina o modus operandi, o papel e o impacto social de uma organização da sociedade civil...

2. ...resultante da existência de um sistema de relacionamento entre diversas audiências ${ }^{*}$ internas e externas à organização, direta ou indiretamente interessadas - os beneficiários, o conselho, a diretoria, os fundadores, a sociedade, a mídia, os beneficiários, o Estado, outras organizações sociais, empresas, a equipe executiva e até mesmo o meio ambiente...

3. ...em diferentes posições de responsabilidade, autoridade e influência.

Idealmente, pode-se dizer que o relacionamento entre as audiências deve ser colaborativo, transparente e que o impacto da organização deve ser sempre positivo. Também podese dizer que os grupos gestores da organização (conselho e/ou diretoria) têm um papel (ou responsabilidade) central no processo, pela posição formal que ocupam.

Nós temos que reconhecer que nossa própria organização somente pode ser bem sucedida se ela se ver a si mesma como um elemento de um biótopo, de toda uma rede inter-dependente de relações entre diferentes organizações e interessados. ${ }^{63}$

Houle (1997) ${ }^{64}$ afirma que o termo governança carrega a conotação de autoridade, controle, responsabilidade e prestígio - que distingue, segundo ele, conselhos de outros grupos humanos indicando um processo bastante complexo. Como principal ator no processo de governança, Houle define conselho como sendo:

Um grupo organizado de pessoas com a autoridade coletiva para controlar e fomentar uma instituição que é normalmente administrada por um gestor qualificado e uma equipe executiva.

\subsection{O PAPEL DE CONSELHO E DE DIRETORIA}

Com base em todo o estudo realizado até agora, a questão deixa de ser qual é o papel do conselho ou qual é o papel da diretoria. Considerando que a diversidade das organizações é enorme, cada uma está num estágio único de um ciclo de vida que lhe é próprio, que o contexto em que estão inseridas é bastante

\footnotetext{
"Audiência tem origem na palavra latina audire, que significa ouvir; ator é definido como agente do ato, aquele que representa; agente é aquele que opera, age, encarregado dos negócios de outrem; constituinte é aquele que constitui, faz parte de um organismo ou sistema, tem o encargo de fazer ou reformar uma constituição, de estabelecer, firmar.

${ }^{63}$ GLASL, F. The enterprise of the future: moral intuition in leadership and organisation development. Inglaterra: Hawthorn Press, 1997.

${ }^{64}$ HOULE, C.O. Governing Boards: their nature and nurture. San Francisco: Jossey Bass, 1997.
} 
específico e que os termos conselho e diretoria podem ser usados com diferentes sentidos, a questão deve migrar para o que é um papel de conselho e o que é um papel de diretoria num sistema organizacional - e se realmente deve existir diferenciação entre ambos em cada caso.

As referências encontradas a respeito do sistema organizacional, e do processo de evolução das organizações no decorrer da sua existência, permitem perceber que três subsistemas interagem continuamente: o subsistema técnico, o subsistema social e o subsistema econômico. Estes sistemas sempre estão presentes nas instituições, com maior ou menor evidência, cada um tendo atividades a eles primariamente vinculadas. Assim, o subsistema técnico compreende atividades especializadas, vinculadas à produção de resultados específicos, que exigem um preparo profissional para sua implementação; o subsistema social compreende as relações entre os diversos constituintes da organização e a integração dos seus esforços através de acordos e rormas; o subsistema econômico compreende uma série de considerações e decisões relativas aos objetivos da instituição, levadas à cabo para assegurar que a organização desempenhe um papel relevante na sociedade. De forma simplificada, o subsistema técnico está voltado primariamente à realização, o subsistema social à administração ${ }^{65}$ e o subsistema econômico à orientação e ao governo da instituição. Diferentes papéis podem ser associados, genericamente, a cada subsistema:

- Subsistema técnico: educador, médico, psicólogo, cozinheira, professora, assistente social, consultor, etc.

- Subsistema social: coordenador, monitor, facilitador, gerente, superintendente, consultor interno, supervisor, diretor, etc.

- Subsistema econômico: fundador, sócio, carregador, presidente, diretor, conselheiro, curador, etc.

Em cada subsistema as funções podem ser diversas, denominando-as do modo como se julgar mais apropriado. Entretanto, nem sempre as diferentes funções relativas a diferentes sistemas são executadas por pessoas diferentes. Uma mesma pessoa (ou grupo) pode concentrar em si atribuições relativas a um, dois ou três subsistemas. $O$ exame das fases de desenvolvimento das organizações mostra, por exemplo, que no início da maioria delas um grupo exerce a liderança nos três subsistemas ao mesmo tempo. Schaefer \& Voors (op. cit.) destacam isso da seguinte forma:

Na fase pioneira, a satisfação dos clientes e a sobrevivência são predominantes enquanto a base econômica da iniciativa estava sendo construída. Na próxima fase de desenvolvimento, critérios técnicos e administrativos têm um papel mais relevante, de modo que a implementação de novos sistemas de informação ou produção para aumentar a eficiência são mais importantes do que seu impacto nas pessoas. Na fase de integração, critérios técnicos, financeiros e sociais ou humanos precisam ser conscientemente balanceados. Se uma iniciativa é vista como contendo estes três subsistemas, então a decisão em uma área tem implicações para as outras.

${ }^{65}$ CHAIT, R.P. Como ajudar seu conselho diretor a governar mais e administrar menos. Washington D.C.: National Center for NonprofitBoards, 1996. 
O que parece ocorrer é que a liderança relativa a cada subsistema pode se diferenciar conforme se avança no ciclo de vida, na maturidade institucional, e são tomadas decisões relativas a cada um deles. 0 comentário de Houle (op.cit.), de que pode ser feita uma diferenciação entre três tipos de atividade: (1) o trabalho a ser feito, (2) a administração deste trabalho e (3) o estabelecimento de diretrizes para guiá-lo, e repetido a seguir, vai nessa direção:

\section{Conforme o tempo passa e a instituição cresce, a distinção entre os três se torna mais pronunciada. O conselho eventualmente precisa de uma equipe executiva para realizar os serviços e, quando essa equipe se multiplica, um gestor é necessário para coordenar e dirigir suas atividades.}

Assim, com o tempo parece natural que um determinado grupo (ou mais de um) assuma a liderança do subsistema técnico, um outro grupo encarregue-se do subsistema social e um terceiro grupo, se for o caso, concentrese mais no subsistema econômico. Isso não significa uma divisão da organização, mas simplesmente uma especialização de um determinado grupo num determinado subsistema - o todo precisa funcionar integrado de qualquer maneira. Se acontecer o predomínio de uma destas lideranças e subsistemas, a organização pode vir a ter problemas.

Esse raciocínio contribui para responder às questões enunciadas anteriormente:

1. Qual a diferença conceitual (não contextual) entre conselho e diretoria?

2. Por que algumas organizações têm um conselho e uma diretoria e outras não?

3. Que tipo de referências podem ajudar a ter maior clareza do papel dos diferentes órgãos relacionados à governança das organizações da sociedade civil?

4. Que tipos de liderança estão relacionados ao processo de governança?

Ou seja, a diferença conceitual entre conselho e diretoria pode ser vista como sendo determinada pela diferença de atribuições e finalidades das lideranças dos subsistemas a que estes órgãos estão vinculados. Considerando que a maioria dos autores (e mesmo a legislação) destaca a existência de um grupo com um papel mais constitucional e orientado aos propósitos da instituição, podese definir o papel de conselho como sendo vinculado àliderança do subsistema econômico - embora o órgão que exerça este papel possa receber a denominação de diretoria, por exemplo, nos estatutos. E considerando que as atibuições de administrar, gerenciar e coordenar uma organização estão mais vinculadas ao subsistema social, pode-se definir como papel de diretoria liderar o subsistema social. Atribuições técnicas específicas estão normalmente vinculadas a instâncias operacionais mais definidas, como, por exemplo, coordenação pedagógica, captação de recursos ou limpeza.

Obviamente, os três subsistemas podem não estar diferenciados suficientemente em órgãos ou instâncias de liderança numa determinada fase da vida da organização - na fase pioneira, descrita anteriormente, a liderança constitucional, organizacional e técnica pode estar concentrada num pequeno grupo ou mesmo numa só pessoa. Essa é uma das razões porque algumas organizações não têm um conselho e uma diretoria: porque não sentiram necessidade disso ou não estão maduras para isso ainda; no nível de evolução em que encontram, com as pessoas que dela fazem parte, no contexto histórico e social em que atuam, provavelmente não há necessidade ainda de diferenciar (ou especializar) determinadas lideranças, 
podendo conviver perfeitamente com um ou dois órgãos somente - que representam, de qualquer maneira, três subsistemas.

Toda esta discussão sugere que os limites entre os três subsistemas não são precisos e bem definidos, consistindo, ao contrário, num continuum. A existência deste continuum justifica muitas discussões a respeito de papéis, atribuições e definição de responsabilidades que acontecem em várias entidades. Estas discussões são relevantes em muitas situações e fundamentais para que o processo de amadurecimento, diferenciação e integração aconteça.

E esse referencial contribui para explicar porque existe muita frustração a respeito do papel de conselhos e mesmo de diretorias. A existência destes órgãos não depende somente de sua inclusão no estatuto ou da decisão arbitrária de alguém - ela está vinculada ao processo de desenvolvimento da organização e da dinâmica de governança em que ela está envolvida. A criação de um conselho quando a instituição não está madura pode levar a desapontamentos, desmotivação e ao surgimento de preconceitos e mitos baseados somente em experiências mal sucedidas, não num entendimento maior do processo organizacional. Aqueles que acreditam em conselhos devem ter paciência e dar atenção não só para o trabalho do conselho, mas à evolução da organização como um todo.

Finalmente, parece existir uma relação entre o processo de governança institucional e o surgimento de diferentes tipos de lideranças dentro das organizações. Quanto maior a complexidade deste processo, maiores são as exigências com relação aos diferentes subsistemas organizacionais, favorecendo mais ou menos a sua diferenciação em órgãos internos. Este ponto tem implicações óbvias para as organizações da sociedade civil modernas. 


\section{Terceira Parte: Exercendo a Governança INSTITUCIONAL}

A pergunta que emerge agora é: o que pode ser feito por uma liderança consciente, no âmbito do conselho e/ou da diretoria, para facilitar este processo de governança institucional e minimizar as dificuldades associadas a ele?

A revisão da literatura permite identificar pelo menos três tipos de abordagem vinculadas à prática dos conselhos dentro da governança institucional: uma abordagem que preconiza o foco em políticas, princípios e diretrizes, liderada por John Carver; uma abordagem contingencial, que preconiza que cada situação é única e que o importante é saber discernir o que é importante naquele momento; e uma abordagem mais comportamental, baseada no desenvolvimento de competências no grupo que exerce a liderança formal da organização.

Estas abordagens são examinadas a seguir; porém, antes faz-se uma rápida discussão de alguns aspectos estruturais dos conselhos, como composição, organização, etc.

\subsection{ASPECTOS ESTRUTURAIS}

Considerase aspectos estruturais aqueles que podem ser definidos a priori, criando certas condições (melhores ou piores) para a manifestação do potencial do conselho. Os principais aspectos estruturais do conselho são: o perfil do conselheiro, a composição do conselho, o mandato, a freqüência de reuniões, a organização interna, o tamanho do conselho e as comissões ou comitês. Estes aspectos são relacionados separadamente por fins de análise, mas evidentemente na prática estão intimamente relacionados. É comum encontrar referências àmaioria dos aspectos estruturais nos estatutos das organizações.

O conselho trabalha melhor se as pessoas envolvidas sabem claramente o que

estão fazendo e se relacionam bem entre si. Mas a estrutura provê apenas os

canais e garantias para a reflexão e ação eficaz. (Houle, 1997)

\subsubsection{PERFIL DOS CONSELHEIROS}

Uma primeira variável estrutural é o perfil dos conselheiros. O pressuposto fundamental aqui é que é possível ter o conselheiro desejado e não aquele que as contingências propiciaram, desde que se desencadeie um processo sistemático e consciente de formação do conselho.

Quando se começa a pensar sobre o perfil de um conselheiro é comum surgir uma lista com as seguintes qualidades, entre outras (Houle, 1997):

- compromisso com a causa da entidade;

- uma posição de respeito na comunidade;

- capacidade de influenciar a opinião pública;

- disponibilidade para servir; 
- abertura, inteligência e coragem.

Este tipo de lista é bastante subjetiva e tem que ser trabalhada com muito cuidado, pois pode criar constrangimentos. Características pessoais são difíceis de serem discutidas e devem ser tratadas com respeito e cuidado - porém, é necessário discuti -las, ao invés de ignorá-las ou deixá-las “implícitas".

Alguns autores sugerem características objetivas para serem consideradas na determinação do perfil dos conselheiros de uma organização da sociedade civil: idade, sexo, local de residência, ligação com uma audiência ou clientela importante da organização, capacidades ou conhecimentos específicos necessários no conselho, entre outras.

É obviamente possível conciliar critérios subjetivos com critérios objetivos para a definição do perfil do conselheiro de uma organização. Tendo estes critérios como orientação, pode-se desencadear um processo para selecionar conselheiros - normalmente uma seqüência de entrevistas e conversas pessoais pode ajudar a avaliar um candidato que não tem ainda contato com a organização, especialmente quanto a características subjetivas.

As pessoas têm diferentes motivações para tornarem-se conselheiras e um erro comum é esperar que todas sintam a mesma coisa (por exemplo, uma disposição altruística) - é mais realista supor que qualquer pessoa que se junta a um grupo novo tem tanto disposições altruísticas, quanto egoístas. O reconhecimento de cada uma contribui para diminuir o número de frustrações posteriores e o surgimento de sentimentos indesejáveis de culpa.

\section{Um conselho nunca se torna totalmente maduro até que seus membros estejam reunidos por devoção àmissão institucional.}

A relação de cada conselheiro com a instituição e com seus colegas se constrói e se fortalece conforme o grupo trabalha junto num conselho. Inicialmente, cada pessoa carrega em si um conjunto de interesses, motivações e expectativas próprias que vão podendo ser colocadas em segundo plano em relação à instituição quando o trabalho e a convivência se desenrolam positivamente.

A fim de garantir que os conselheiros aceitem conscientemente (e não por impulso) a responsabilidade inerente à esta posição, Houle sugere que pelo menos quatro perguntas devem ser consideradas com muita seriedade:

(a) Do que eu preciso abrir mão para assumir adequadamente esta nova responsabilidade?

(b) Quais são as expectativas dos outros e as minhas próprias? Qual é a condição real que eu tenho de satisfazê-las?

(c) Em que medida a aceitação deste papel contribui para a realização dos meus ideais de sociedade e crescimento pessoal?

(d) Qual será a recompensa para a sociedade e para mim pessoalmente por me tornar conselheiro desta instituição?

De forma geral, é preciso que o potencial conselheiro conheça e aceite as responsabilidades atribuídas a um membro de conselho - especialmente porque o conselho como um todo tem atribuições e não somente seus membros individualmente. 


\subsubsection{COMPOSIÇÃO DO CONSELHO}

Uma outra variável estrutural do cons elho é a sua composição. Enquanto o perfil do conselheiro trata das características que cada conselheiro deve ter (ou não ter), a composição do conselho diz respeito ao conjunto das pessoas com seus diferentes perfis. A despeito de uma instituição determinar que todos os conselheiros devem ter um certo perfil mínimo desejado (ou pelo menos não ter um certo conjunto de qualidades), o conselho pode ter uma composição heterogênea e diversificada.

Sobre composição dos conselhos, é comum encontrar citações sobre duas dimensões: diversidade e representatividade. Diversidade refere-se à inclusão no conselho de pessoas diferentes em determinados aspectos (por exemplo, raça, sexo, idade, etc.); representatividade é a sua ligação com alguma audiência importante para a organização. Segundo Houle (1997), um teste para o sucesso de um conselho reside na sua habilidade em tirar proveito da diversidade de seus membros para obter o melhor resultado possível para a organização.

$\mathrm{Na}$ construção da composição de um conselho, algumas etapas podem ser diferenciadas: a primeira consiste na verificação explícita do perfil ideal do conselho; uma outra é a definição da composição do perfil atual do conselho - a comparação entre ambas facilita a determinação de lacunas que podem orientar o processo de recrutamento e renovação a ser desencadeado.

Algumas perguntas podem ser feitas a respeito da composição de um conselho, como "Quão bem estão representadas as audiências essenciais da organização?", "Que tipo de diversidade existe neste conselho?", "Que tipos de pessoas devem ser convidadas a se aproximar do conselho?", "Com o vencimento de alguns mandatos, como pode ficar a composição do conselho?".

A construção de uma composição adequada do conselho pode ser demorada, pela dificuldade em encontrar novos membros dentro do perfil desejado. Para isso, alguns artifícios são utilizados, como a criação de um comitê específico de recrutamento de novos conselheiros, a consulta à diretoria e equipe executiva e a realização de entrevistas. O essencial, entretanto, é que a composição de um conselho (desde a procura de nomes até o convite e a orientação de um novo membro) não deve ser realizada às pressas, nem de maneira casual - ao contrário, deve ser um processo criterioso e planejado.

O primeiro momento em que uma pessoa se encontra com um conselho é crucial para iniciar sua educação e orientação.

Um aspecto importante relacionado à composição do conselho é a orientação a novos membros, com o fim de ampliar seu conhecimento do contexto em que vai atuar e nutrir seu engajamento. Vários procedimentos podem ser utilizados com o fim de preparar um novo conselheiro para suas funções, desde apoio individual por um membro mais experiente até o oferecimento de um "manual do conselheiro".

\subsubsection{TAMANHO DO CONSELHO}

A regra geral para definição do tamanho do conselho é de que ele deve ser pequeno o suficiente para atuar como uma instância deliberativa e grande o necessário para poder arcar com as suas responsabilidades. Porém, é de se esperar que o tamanho da maioria dos conselhos existentes seja muito influenciado pela história da organização. 
A determinação do tamanho do conselho está primariamente vinculada aos estatutos da organização, mas a sua correta manutenção é considerada uma tarefa de responsabilidade do próprio conselho. Em quase todos os casos o tamanho ideal é bastante subjetivo, existindo o risco de se formar um conselho muito grande ou muito pequeno.

Para evitar que o conselho se torne muito grande, deve-se ter em mente que haverão reuniões, nestas reuniões deverão ser tomadas algumas decisões e estas decisões devem ser coletivas - o tamanho do conselho deve ser tal que possibilite isto acontecer. Conselhos grandes demais podem ter dificuldades para tomar decisões ou as tomar de maneira que o envolvimento das pessoas seja prejudicado.

Por outro lado, para evitar que o conselho se torne muito pequeno recomenda-se verificar com cuidado as responsabilidades a ele atribuídas. $O$ conselho precisa ter um tamanho compatível com as suas atribuições - caso seja muito pequeno, correrá o risco de não exercer o papel de liderança desejado ou exigido pela organização.

Uma regra simples geralmente aceita é a de utilizar números ímpares de conselheiros, para o caso de ser necessária uma decisão por votação e houver necessidade de um "voto de Minerva".

\subsubsection{DURAÇÃO DO MANDATO}

Obviamente, os estatutos da organização determinam a duração do mandato dos conselheiros e devem ser respeitados; mas nem sempre estão alinhados àrealidade e podem ser tão flexíveis e abertos que permitem que alguém fique no conselho por um número ilimitado de anos. Assim, uma das perguntas que se pode fazer sobre isso é "Quando é hora de sair?".

A definição de por quanto tempo um conselheiro deve permanecer no conselho depende, portanto, da reflexão, individu al primariamente, a respeito de perguntas como:

- Qual é o meu interesse atual na missão da entidade?

- Que tipo de suporte e assistência estou provendo para a entidade?

- Como está a credibilidade do conselho, da diretoria e da equipe executiva?

- Quem poderia oc upar meu lugar no conselho de maneira mais efetiva?

- Em que medida minha permanência ou retirada do conselho contribuiria para o fortalecimento deste?

- Que tipo de papel eu preciso assumir para melhor realizar minha tarefa de vida neste momento?

Esta reflexão deve abranger, além disso, a complexidade dos problemas em que a entidade atua, o tamanho da organização, a necessidade de renovação, a estabilidade institucional, o número de audiências a que serve, o contexto político e cultural do momento, a disposição das pessoas em participar de conselhos, etc. De maneira geral, entretanto, o mandato precisa ser longo o suficiente para que haja algum tipo de continuidade, mas curto o bastante para assegurar a renovação de mentalidade institucional.

Alguns mecanismos são utilizados para regular a permanência de uma pessoa no conselho, como a limitação formal do número de anos no conselho, a superposição de mandatos (ou renovação parcial a cada período) e a permissão ou não de uma ou mais reeleições. 


\subsubsection{ORGANIZAÇÃO INTERNA}

O conselho é em última instância um grupo de pessoas trabalhando juntas sob algumas atribuições para alcançar determinados fins. Para que ele funcione bem na maioria das situações faz-se necessário algum tipo de coordenação e facilitação do trabalho. Assim, abre-se espaço para a determinação de alguns papéis diferenciados dentro dos conselhos. Neste item cada instituição tem uma necessidade própria, devendo definir quais papéis devem existir, respeitando os parâmetros legais cabíveis. Por exemplo, é comum encontrar quatro papéis principais: presidente, vice-presidente, secretário e tesoureiro, com suas atribuições determinadas pelos estatutos. O presidente tem como responsabilidade fundamental assegurar a integridade do trabalho do conselho (o que o conselho faz). A função de vicepresidente costuma existir para o caso de uma eventual ausência do presidente ou como preparação de um potencial sucessor do presidente. O tesoureiro concentra sua atenção na transparência da gestão de recursos. O secretário tem por responsabilidade a manutenção dos documentos relativos ao trabalho do conselho (o que o conselho fez). É importante considerar, entretanto, que estas funções somente devem existir para ajudar o conselho a cumprir seu papel, não representando nenhum poder em si próprias. Além disso, estas posições têm a finalidade precípua de coordenar, não significando que o conselho dependa deles.

Tendo definidos os papéis formais a existir, a atenção volta-se para a seleção das pessoas que vão ocupar estas posições. Especialmente com relação à posição de principal liderança formal (presidente, por exemplo), o ideal é que haja sempre disponível várias pessoas para ocupá-la - o que implica num constante trabalho de fortalecimento e desenvolvimento de lideranças. O preenchimento destes "cargos" pode algumas vezes tomar um caráter competitivo, quando há mais de um candidato qualificado. Segundo Houle, o ideal é que algum tipo de acordo ou composição seja feito, levando em consideração que um conselho é naturalmente um local onde devem coexistir, pelo menos filosoficamente, diferentes pontos de vista. Quando isso não for possível, deve haver um trabalho posterior às eleições para tratar as relações existentes entre vencedores e vencidos. Outros problemas podem ocorrer no preenchimento destas posições, sendo necessário atentar para o processo, muito mais do que para a estrutura em si.

Pode-se ter tanto indivíduos ocupando posições diferenciadas dentro dos conselhos, quanto grupos. Assim, um outro mecanismo de organização muito usado é o estabelecimento de comitês ou comissões, que podem ser de pelo menos três tipos diferentes:

1. Comitês permanentes: são aqueles que permanecem existindo indefinidamente para tratar de certos tipos de assuntos ou questões regulares na organização, como planejamento dos programas, recrutamento de conselheiros, orçamento, entre outros;

2. Comitês especiais: são formados para lidar com situações específicas, deixando de existir quando não for mais o caso - este tipo de comitê pode estar relacionado à organização de um evento, à representação do conselho em um processo ou àseleção de um diretor executivo, por exemplo;

3. Comitês executivos: existem para prover orientação e direção geral, acompanhando mais de perto as atividades cotidianas da organização - um pequeno grupo que se reúne regularmente para resolver questões administrativas, preparar recomendações, solucionar emergências, elaborar planos futuros e avaliar resultados; pode compor-se de membros do conselho, diretor executivo, presidente do conselho e mais duas ou três pessoas especialmente escolhidas para tal. 
A existência de comitês está relacionada ao tamanho do conselho - conselhos pequenos dificultam o uso deste tipo de estrutura. Ao se decidir sobre a criação de um comitê, Houle sugere que fiquem expressos por escrito (por exemplo, na ata de uma reunião do conselho) tanto as suas atribuições, como suas principais metas. Um comitê tem somente o poder que o conselho delegou a ele, devendo realizar aquilo que explicitamente se espera dele (uma tentação é substituir o papel do conselho).

A escolha pelo uso de comitês, de acordo com Carver, também deve ser baseada nas demandas e necessidades do processo de governança, tomando o cuidado para não interferir na administração da entidade. Comitês têm condições de trabalhar com um nível maior de detalhes do que o conselho como um todo, mas correm o risco de assumirem tarefas executivas que muitas vezes são de responsabilidade da equipe profissional e de perderem a perspectiva macro institucional.

Quando o conselho cria comitês com títulos que duplicam funções executivas, estes comitês provavelmente serão levados a mergulhar no trabalho técnico.

Como o conselho é um órgão colegiado, sendo essencial a sua atuação coletiva, qualquer subdivisão pode ameaçar sua totalidade, pois pode "enrijecer" o funcionamento do conselho, fragmentar o fluxo de informações ou favorecer a atuação de somente um subgrupo e não do conselho todo - assim, um princípio importante é não ter mais funções e comitês do que o absolutamente n ecessário.

Um sub item da organização interna do conselho é relativo aos procedimentos operacionais, sendo o principal deles as reuniões.

De quanto em quanto tempo deve um conselho se reunir? Algumas variáveis influem sobre essa definição. A primeira delas diz respeito às responsabilidades do conselho - dependendo da sua abrangência e profundidade, pode ser necessário que o conselho se reuna com maior freqüência. Na maioria das entidades, o contexto institucional determina o propósito do conselho - sua avaliação pode auxiliar na definição do ritmo ideal de reuniões.

Outra variável é o tipo de reunião - o conselho pode definir para si diferentes tipos de reuniões, desde autoavaliação até o encaminhamento de projetos e o planejamento institucional. Para cada tipo de reunião pode ser necessária uma freqüência diferente.

Dependendo da qualidade e da intensidade da comunicação entre os conselheiros e o grau de contato que têm com as atividades organizacionais, pode ser necessário um maior ou menor número de reuniões do conselho.

Como reuniões são os espaços primordiais onde o conselho atua em conjunto, é fundamental considerar sua qualidade. Reuniões podem ser eficientes ou ineficientes, dependendo da habilidade do grupo em trabalhar em conjunto. É preciso considerar com bastante honestidade e franqueza como são as reuniões do conselho para cogitar de um intervalo maior ou menor entre elas, bem como para alterar sua duração.

\subsection{ABORDAGEM ORIENTADA POR POLÍTICAS}

Carver (1997) considera que os conselhos têm uma tarefa bastante especial no processo de governança institucional, que exige também a aplicação de princípios especiais para que possa ser bem desempenhada. $O$ não entendimento de alguns destes princípios pode tornar o conselho uma instância 
meramente reativa ou aprovadora, operando a partir de técnicas de solução de problemas e contribuindo somente para a adoção de respostas paliativas e frustrantes. Para ele, quando a função do conselho é construída simplesmente a partir da história da organização, ao invés de desenhada a partir de uma visão abrangente e proativa, este deixa de incorporar e manifestar boa parte do seu potencial.

O papel especial atribuído aos conselhos advém de algumas características inerentes a este grupo:

1. O conselho é o último elo ou nível com responsabilidade formal pela instituição;

2. O conselho é o responsável final pela prestação de contas à sociedade e a ela moralmente subordinado;

3. O conselho é um conjunto de indivíduos operando como uma entidade única, como um dirigente coletivo;

4. O conselho é um grupo que tende a rejeitar subordinação, sendo naturalmente menos disciplinado do que indivíduos isolados;

5. Conselhos tendem a permanecer boa parte do tempo fisicamente distantes da organização;

6. O trabalho do conselho é essencialmente verbal: o conselho fala, tendo como principal instrumento de trabalho as palavras.

Quando o trabalho é feito com palavras, é preciso haver disciplina no falar. Essa disciplina abrange o quê se fala, como a conversa ocorre equando se dá.

Para que a governança exercida por um órgão como este tenha sucesso, deve-se esperar que ela: sustente e fortaleça a visão institucional; explicitamente trate dos valores institucionais; tenha um foco para fora da organização e uma responsividade externa; mantenha o sistema voltado para resultados; separe as grandes das pequenas questões; estimule o raciocínio de longo prazo e a preocupação com o longo prazo; garanta proatividade e criatividade; facilite a diversidade e a unidade; descreva e fortaleça as relações com diferentes audiências e constituintes da organização; defina uma base comum para aprendizagem e orientação; delineie o papel do conselho em assuntos comuns; determine que tipo de informação é necessária; propicie um equilíbrio entre sub e super controle; use o tempo eficientemente.

Assim, são atribuídos três grandes papéis ao conselho: (i) manter a ligação da organização com seus constituintes primários; (ii) expressar as políticas básicas de governança da instituição; (iii) e assegurar o desempenho da liderança executiva.

Para Carver, "o segredo desta nova forma de governança está na definição de políticas, mas políticas de um tipo bastante refinado". Assumindo que toda organização toma decisões e comporta-se de acordo com um determinado conjunto de valores, crenças e princípios, implícitos ou explícitos, a excelência da governança advém da premissa que o reconhecimento e a utilização consciente destes valores, crenças e princípios pode afetar significativamente o desempenho e a efetividade da organização. Ao focalizar sua atenção diretamente a estes elementos, o conselho se aproxima e pode intervir sobre as bases essenciais do comportamento organizacional. Políticas, portanto, referem-se a esta mistura de valores, crenças e princípios institucionais. 
Para alcançar o núcleo do sentdo organizacional, os conselhos precisam se preocupar com políticas. Mas porque o desafio central é liderar, ao invés de analisar, a governança tem que propor, em vez de meramente deduzir, políticas.

Ao operar sobre os elementos mais fundamentais de uma ơganização, propondo e adotando políticas explícitas e consistentes e zelando pela sua renovação, esperase que o conselho obtenha um maior alcance sobre as questões institucionais com um esforço menor, sem necessitar de qualificações especializadas, de forma legítima e propiciando inspiração e motivação. Na prática, isto significa fazer questões do tipo:

- Que tipo de políticas estão representadas numa situação determinada?

- Como uma certa situação se relaciona às políticas previamente definidas?

- Que tipo de políticas estão implícitas ou dão embasamento a instrumentos como o orçamento ou o plano anual?

O ponto central desta forma de trabalho do conselho é o estabelecimento de um processo preliminar e predominante de definição e revisão de políticas que digam respeito a quatro campos:

(a) a finalidade e os objetivos da organização - os fins, como indica Carver;

(b) a meios éticos e prudentes para realizar estes fins - especialmente pela explicitação daquilo que não deve ser feito;

(c) ao relacionamento entre as diferentes instâncias organizacionais;

(d) e ao processo de governança como um todo, incluindo a atuação do próprio conselho.

Embora políticas sempre existam nas mais diversas circunstâncias da atividade organizacional (pelo menos implícitas), para que a governança sej a efetiva propõe-se que elas sejam:

1. Explícitas: devem existir na forma escrita;

2. Correntes: políticas atuais são as únicas que têm valor;

3. Literais: devem significar aquilo que dizem, evitando ambigüidades;

4. Disponíveis: preferencialmente devem estar centralizadas de modo a que todos possam acessá-las quando for preciso;

5. Curtas: brevidade pressupõe simplicidade;

6. Inclusivas: devem abranger diversos aspectos organizacionais e a sua integridade.

Por representarem artefatos intangíveis, políticas têm uma característica lógica e hierárquica: aquelas mais abrangentes ("macro") abarcam um certo conjunto de políticas mais específicas ("micro"). Esta característica contribui para a definição dos limites do trabalho do conselho: ele deve concentrar-se nas políticas mais abrangentes e as ir detalhando até um limite em que qualquer interpretação (pela equipe executiva) seja aceitável. Quando qualquer resposta baseada numa determinada política for considerada satisfatória, o conselho pode delegar a sua implementação, assegurando o direcionamento comum. Os seguintes princípios se aplicam: 
a) O conselho deve resolver as questões mais amplas e abrangentes em cada categoria antes de lidar com as questões menores e mais específicas, para evitar que fique vagando de uma questão a outra;

b) Os níveis menores podem ser trabalhados antes, desde que em seqüência, evitando saltar níveis;

c) O conselho deve garantir à equipe executiva toda a autoridade e liberdade para tomar quaisquer decisões dentro das diretrizes oferecidas pelas políticas.

A única forma pela qual o conselho pode criar políticas unificadas é fazendo-as como um todo.

O reconhecimento desta hierarquia de objetivos e o seu uso disciplinado na direção proposta permite que o conselho trabalhe com um amplo grau de diversidade de opiniões, na medida em que ele deve extrair concordância primeiro nas posições mais amplas. Segundo Carver, o conselho tem que se preocupar menos em aprovar o orçamento e mais em determinar as políticas para elaboração do orçamento; não em elaborar um plano de salários, mas sim em definir políticas de remuneração; não em fazer o planejamento estratégico, mas em dar diretrizes para ele; não em aprovar propostas da liderança executiva, mas em estabelecer aquilo que ela não deve fazer, por exemplo. Dentro desta filosofia, os comitês devem somente fazer o trabalho pré-conselho (não sub-conselho), encarregando-se de apresentar várias opções de políticas ao conselho e suas implicações. Nas reuniões, o conselho deve preocupar-se menos em discutir todos os assuntos a ele apresentados e mais em questionar porque eles estão na sua agenda, dedicandose a construir sua própria programação de trabalho.

O conselho deixa de tentar ser a autoridade final e ao invés disso torna-se a autoridade inicial.

Este tipo de abordagem preconiza a colocação do conselho numa posição menos reativa e aprovadora, mantendo-o devidamente distanciado de questões excessivamente operacionais e assegurando uma adequada liberdade de ação para a equipe executiva. O desenvolvimento de políticas não é vista como uma tarefa ocasional do conselho, mas sua ocupação principal, uma responsabilidade assumida, mobilizando sua capacidade de antecipar situações e delinear a priori aquilo que deve acontecer e não acontecer. Em última instância, o conselho é colocado, nas suas diversas áreas de atuação, não como responsável pelas atividades da instituição, mas pelos seus resultados.

Sinteticamente, os principais pressupostos desta abordagem são:

- O conselho tem um papel representativo dos "donos morais" da organização;

- A autoridade do conselho reside no grupo, não nos seus indivíduos;

- $\quad$ As decisões do conselho devem sempre afetar as políticas institucionais;

- Primeiramente devem ser formuladas políticas mais amplas, para depois progressivamente trabalhar sobre políticas mais específicas;

- $\quad$ O conselho define e delega, ao invés de reagir e ratificar;

- O tarefa central da governança é a determinação de propósitos e finalidades;

- O conselho pode melhor controlar a equipe executiva pela limitação, não pela prescrição; 
- O conselho deve explicitamente definir os resultados do seu trabalho e a forma como ele vai ser feito;

- Deve existir uma ligação segura e poderosa do conselho com a liderança executiva;

- A avaliação da liderança executiva somente é efetiva quando realizada em comparação com políticas pré-definidas pelo conselho.

Oliver et allii (1999) ${ }^{66}$ realizaram um estudo junto a onze organizações americanas sobre a Governança por Políticas e concluíram que seu atrativo advém: da clareza de papéis entre conselho e liderança executiva, de uma reorientação da energia do conselho (em direção à missão) e do estabelecimento de cargas de trabalho suportáveis. Os fatores mais críticos para a implementação e continuidade deste tipo de abordagem pelo conselho foram:

- O comprometimento do conselho como um todo para a adoção do modelo;

- A habilidade do grupo de conselheiros em trabalhar em grupo - a disciplina de grupo requerida por esta abordagem representou um obstáculo considerável para vários conselhos;

- O profundo entendimento dos seus princípios, muitas vezes obtida através de sessões de treinamento;

- $\quad$ A presença de um grupo de liderança forte;

- Um processo regular de auto-avaliação;

- Uma cultura de auto -disciplina, com os conselheiros se ajudando mutuamente a manter a disciplina;

- O uso de estruturas e ferramentas específicas, como um plano de trabalho, um calendário anual e modelos de políticas;

- Uma relação de confiança mútua entre a liderança executiva e o conselho.

Segundo esses autores, durante a implementação deste modelo foi comum encontrar conselheiros com certo sentimento de "perda", pelo afastamento do nível operacional da organização. E outros tipos de "perdas" foram notadas: perda da "conexão" com a organização (um sentimento de separação mais pronunciado), da satisfação por resultados imediatos, da liberdade de falar à vontade, da clareza da sua contribuição, de um senso de responsabilidade, do poder pessoal sobre a organização.

No trabalho com políticas, os conselhos encontraram maiores dificuldades na construção daquelas relativas às finalidades das organizações - os conselhos pesquisados tiveram maior trabalho para responder a questões do tipo "Que tipo de benefício a organização proporciona? Para quem?”. Na mesma linha, um ponto considerado desafiador foi a definição dos "donos morais" da organização, uma vez que neste modelo faz-se uma distinção entre os "donos morais" da organização e seus clientes.

Quando a Governança por Políticas é adotada apenas parcialmente e a definição das finalidades não começou, os conselhos se sentem desconectados das suas organizações. ... Quando não estão ativamente envolvidos na determinação dos

${ }^{66}$ OliVER, C., CONDUFF, M., EDSALL, S., GABANNA, C., LOUCKS, R., PASZKIEWICZ, D., RASO, C. \& STIER, L. The policy governance fieldbook: pratical lessons, tips and tools from the experience of real-world boards. San Francisco: Jossey-Bass, 1999. 
fins organizacionais, os conselhos mostram-se incertos sobre o que deveriam fazer.

As maiores críticas ao sistema de governança por políticas apontadas no estudo referem-se:

(a) O modelo não é aplicável a todas as situações, uma vez que o universo das organizações da sociedade civil é tão variado que é ingenuidade esperar que ele possa ser efetivo em todas elas;

(b) A governança por políticas é muito rígida, suscitando muitas resistências de conselheiros a prescrições do tipo "tudo-ou-nada";

(c) Este sistema distancia o conselho da realidade, pela separação entre política e implementação.

Em resposta a estas críticas, os autores consideram que o modelo ainda representa um ideal difícil de ser posto em prática, porém não impossível; além disso, apresenta um rol de conceitos e princípios básicos que devem sim ser seguidos para que o sistema funcione, mas estes princípios podem ser colocados em ação através de diversas práticas, de acordo com as condições de cada organização. Quanto à separação entre política e implementação, observoutse em diversos casos estudados que de fato alguns conselheiros sentiram uma certa separação das atividades da organização - os autores enfatizam, entretanto, que este sentimento deixa de existir assim que o conselho define as políticas relativas às finalidades da organização, sendo substituído por um senso de que finalmente está-se fazendo um trabalho significativo.

\subsection{ABORDAGEM CONTINGENCIAL}

De fato, alguns autores consideram que o universo das organizações da sociedade civil e do terceiro setor é tão diversificado e o processo de governança institucional tão dinâmico e complexo que torna-se bastante arriscado assumir que um determinado modelo de atuação do conselho possa ser satisfatório e oferecer respostas adequadas a todos os casos, mesmo que sejam respeitados todos os seus princípios.

Wildmer \& Houchin $(2000)^{67}$ recomendam uma abordagem contingencial à governança institucional, considerando que cada organização é diferente e que as variáveis em questão são extremamente numerosas.

O principal pressuposto, portanto, que fundamenta a abordagem contingencial é que para ser efetivo um conselho tem que se organizar e trabalhar de acordo com os valores e características da organização e do contexto em que ela se encontra. Ou seja, a maneira com que cada conselho atua pode ser diferente em função da situação em que ele se encontra e o próprio conselho é responsável por definir como deve atuar naquela contingência. Afirmações como essas fazem parte de uma abordagem contingencial:

O envolvimento dos conselheiros no processo orçamentário depende do tamanho e da complexidade da organização. ... Em pequenas organizações, a liderança executiva e o conselho podem implementar as estratégias de captação de recursos.

${ }^{67}$ WILDMER, C. \& HOUCHIN, S. The art of trusteeship: the nonprofit member's guide to effective governance. San Francisco (EUA): Jossey-Bass, 2000. 
Além destes, outros pressupostos compõem a abordagem contingencial para o trabalho do conselho:

1. Os conselhos devem dedicar a maior parte do seu tempo em questões de importância crítica para a organização;

2. As decisões devem ser tomadas pelo conselho como um todo, pois os conselheiros individualmente não têm autoridade para tal (a menos que delegada pelo conselho);

3. Os conselheiros podem atuar de diferentes maneiras, mas devem sujeitar-se aos mesmos padrões de conduta;

4. A maioria dos conselhos exercem responsabilidades básicas semelhantes, porém de diferentes maneiras:

5. Somente o profundo entendimento da filosofia e dos programas institucionais possibilita aos conselheiros exercerem adequadamente suas responsabilidades.

Os padrões de conduta referem -se a deveres intrínsecos à posição de conselheiro: dever de cuidar, dever de lealdade e dever de obediência. O primeiro diz respeito ao dever de guarda da instituição, devendo os conselheiros agir com prudência e sabedoria em todas as suas decisões. O dever de lealdade implica que cada conselheiro compromete-se a colocar os interesses da organização em primeiro lugar em relação aos interesses próprios e de outros. Ao assumir o dever de obediência, os membros do conselho subordinam-se àmissão e aos estatutos da entidade.

\subsubsection{RESPONSABILIDADES ATRIBUÍDAS AO CONSELHO}

O conceito de responsabilidade é tão importante para a abordagem contingencial, quanto o conceito de política para abordagem trazida por Carver, apresentada anteriormente. Responsabilidade diz respeito àquilo que o conselho assume como compromisso, àquilo por que o conselho responde, devendo para tal mobilizar todos os seus esforços e talentos.

Em seu livro "Ten Basic Responsibilities of Nonprofit Boards", INGRAM (1997) propôs-se a clarificar e distinguir as responsabilidades do conselho como uma entidade coletiva. Para ele, o primeiro passo para o serviço efetivo de um conselho é reduzir as várias ambigüidades que inevitavelmente o acompanham. INGRAM, para isso, apresenta as seguintes premissas:

1. As responsabilidades do conselho e dos conselheiros são fundamentalmente as mesmas para todas as organizações (apesar de quase todas as pessoas sentirem que sua organização é única e especial);

2. A forma com que os conselhos e conselheiros exercem estas responsabilidades varia, por diversos fatores;

3. Nenhum modelo genérico de conselho - tamanho, composição ou organização - é viável em todas as circunstâncias;

4. Todas as organizações passam por metamorfoses com o passar do tempo, que requerem uma revisão periódica, ajustamento e, algumas vezes, maiores mudanças nas suas estruturas de governo; 
5. Conselhos e conselheiros apresentam melhor desempenho quando exercitam suas responsabilidades primariamente fazendo perguntas boas e freqüentes, ao invés de dirigir programas ou implementar suas próprias políticas.

As responsabilidades básicas de conselhos de entidades sem fins lucrativos apresentadas naquele trabalho são:

Determinar a missão e os objetivos da organização.

Selecionar o chefe executivo.

Apoiar o diretor executivo e avaliar sua performance.

Assegurar um efetivo planejamento organizacional.

Assegurar recursos adequados.

Gerenciar recursos adequadamente.

Melhorar a imagem pública da organização.

Assegurar integridade legal e ética e a transparência da organização.

Recrutar e orientar novos conselheiros e avaliar sua própria performance.

INGRAM (1997) sugere que existem outras responsabilidades para o conselho, mas que atenção deve ser dada para distinguir claramente entre responsabilidades do conselho e responsabilidades do conselheiro.

Para Wildmer e Houchin os conselhos das organizações da sociedade civil têm dez responsabilidades fundamentais, que podem ser agrupadas em três categorias: aquelas relativas à missão da entidade, aquelas referentes aos recursos para sua operação e àquelas que dizem respeito à gestão organizacional. Essas dez responsabilidades são:

- Estabelecer e revisar a missão da organização e monitorar o progresso da organização em alcançá-la;

- Criar uma visão para o futuro da entidade e desenvolver um plano para realizá-la;

- Assegurar que os programas e serviços institucionais promovam a missão da organização, que atendam às necessidades dos seus clientes e que sejam avaliados por sua eficácia;

- Assegurar que a organização comunique-se com seus vários públicos;

- Supervisionar a aplicação dos recursos institucionais, definindo políticas de gestão financeira, aprovando e monitorando o orçamento e realizando uma auditoria anual;

- Assegurar que a organização tenha recursos suficientes para realizar seu trabalho, aprovando um plano de desenvolvimento de fundos, fazendo contribuições individuais e participando de atividades de captação de recursos;

- Identificar e prevenir riscos para a instituição;

- Selecionar, apoiar, avaliar e, se necessário, demitir a liderança executiva;

- Selecionar, orientar e educar novos conselheiros a respeito da organização e da sua tarefa como conselheiro; 
- Determinar como será o trabalho do próprio conselho, incluindo sua organização, suas reuniões e avaliação.

A título de comparação, convém saber que no seu livro "Introdução àadministração", publicado no Brasil em 1984, Peter Drucker apresenta as atribuições da "alta administração", afirmando que nenhum empreendimento funcionará melhor do que sua alta administração o permita ("pois o gargalo está sempre à cabeça da garrafa", diz ele). As principais tarefas a cargo da alta administração são:

(a) Raciocinar sobre a missão e fixar objetivos, estratégias e planos, tomando hoje decisões que produzirão os resultados de amanhã;

É claro que isso só pode ser conseguido por um órgão da empresa que possa observá-la no seu todo; que possa tomar decisões que a atinjam por inteiro; que possa pesar os objetivos e as necessidades de hoje em relação às necessidades do amanhã...

(b) Fixar padrões e dar exemplos;

(c) Construir e conservar a organização humana;

(d) Travar e manter relações externas;

(e) Dedicar-se a funções "cerimoniais";

(f) Manter-se "de prontidão" para enfrentar as crises mais graves.

Os textos que tratam da administração concordam em que a alta administração não deve "operar".

Para este "guru" da administração, falando da empresa, o conselho é aquele órgão que supervisiona a alta administração, assessoraa, revisa suas decisões e nomeia seus membros. Ele tem três funções básicas: assessorar a alta administração e deliberar junto com ela, demiti-la quando seu desempenho for falho e encarregar-se das "relações públicas e comunitárias", provendo informação, assessoria, aconselhamento e comunicação.

Num trabalho sobre conselhos (ou diretorias) de organizações que atuam na área da saúde, Holland et allii $(1997)^{68}$ apresentam o conselho como um representante da comunidade, responsável por: selecionar, apoiar e avaliar a equipe executiva; revisar e aprovar diretrizes estratégicas de longo prazo; garantir uma disponibilidade adequada de recursos humanos e financeiros; garantir que a organização opere de forma responsável e eficaz; assumir responsabilidade pela seleção de novos conselheiros e por estabelecer um sistema eficiente de governança.

${ }^{68}$ HOLLAND, T.P., RITVO, R.A. \& KOVNER, A.R. Improving board effectiveness: practical lessons for nonprofit health care organizations. Chicago: American Hospital Publishing, 1997. 
Para Bundy $(1990)^{69}$, o conselho de fundações tem pelo menos três responsabilidades morais e sociais, a saber: conceber programas, escolher a liderança executiva e assegurar que as atividades da fundação sejam total e honestamente explicadas ao público e às autoridades interessadas.

Evidentemente, o conselho tem o papel de supervisionar e nutrir não somente a organização, mas o processo de governança institucional.

A literatura referente à abordagem contingencial faz freqüentes referências às responsabilidades dos conselhos, trazendo sugestões e exemplos de como o conselho pode fazer para realizá-las. As recomendações mais encontradas dizem respeito ao uso de perguntas, ao planejamento do seu trabalho e àauto-avaliação regular.

O uso de perguntas pelo conselho exige que este analise e reflita sobre uma determinada situação e busque o encontro de respostas adequadas àquela circunstância específica. Espera-se que o conselho levante para si próprio questões abertas referentes à missão, aos recursos e à gestão institucional, conforme exemplificado no quadro abaixo, adaptado de Wildmer e Houchin:

\begin{tabular}{|c|c|}
\hline Categoria & Questões \\
\hline \multirow[t]{3}{*}{ Missão } & A formulação atual da missão transmite realmente aquilo que se quer assumir? \\
\hline & $\begin{array}{l}\text { Os programas e serviços oferecidos estão consistentes com a missão } \\
\text { institucional? }\end{array}$ \\
\hline & $\begin{array}{l}\text { Todos os conselheiros e membros da equipe executiva entendem e sustentam } \\
\text { a missão institucional? }\end{array}$ \\
\hline \multirow{3}{*}{$\begin{array}{l}\text { Planejamento } \\
\text { Estratégico }\end{array}$} & O conselho tem um plano para planejar? \\
\hline & O conselho implementou e avaliou as decisões do último plano institucional? \\
\hline & $\begin{array}{l}\text { O conselho usa os objetivas e estratégias do plano institucional para orientar } \\
\text { seu trabalho? }\end{array}$ \\
\hline \multirow{3}{*}{$\begin{array}{l}\text { Supervisão e } \\
\text { monitoramento dos } \\
\text { programas }\end{array}$} & Os programas e serviços da entidade estão congruentes com a missão? \\
\hline & $\begin{array}{l}\text { O conselho tem solicitado à equipe executiva que levante as necessidades da } \\
\text { comunidade antes de iniciar novos programas? }\end{array}$ \\
\hline & Como o conselho avalia os programas e serviços da instituição? \\
\hline \multirow{3}{*}{$\begin{array}{l}\text { Comunicação e } \\
\text { relacionamento com os } \\
\text { públicos da } \\
\text { organização }\end{array}$} & A organização tem um plano para contar sua história para a comunidade? \\
\hline & $\begin{array}{l}\text { Os conselheiros entendem a missão bem o suficiente para falar sobre ela em } \\
\text { eventos na comunidade? }\end{array}$ \\
\hline & O conselho advoga em favor da missão e dos clientes desta instituição? \\
\hline \multirow[t]{3}{*}{ Supervisão financeira } & O conselho revê regularmente os relatórios financeiros simplificados? \\
\hline & O conselho adota políticas e orçamentos mas evita entrar na micro gestão? \\
\hline & $\begin{array}{l}\text { O conselho contrata um auditor e usa sua informação para exercer suas } \\
\text { responsabilidades fiduciárias? }\end{array}$ \\
\hline
\end{tabular}

${ }^{69}$ BUNDY, M. The moral and social responsibilities of the trustees of foundations. In: GIES, D.L., OTT, J.S. \& SHAFRITZ, J.M. The nonprofit organization: essential readings. Belmont: Wadsworth Publishing Company, 1990. 


\begin{tabular}{|c|c|}
\hline Categoria & Questões \\
\hline \multirow[t]{3}{*}{$\begin{array}{l}\text { Desenvolvimento de } \\
\text { fundos }\end{array}$} & $\begin{array}{l}\text { A organização tem um plano anual de captação de recursos que envolve } \\
\text { diversas estratégias e fontes? }\end{array}$ \\
\hline & Todos os conselheiros participam em algum aspecto da captação de recursos? \\
\hline & Os conselheiros fazem alguma contribuição anual àorganização? \\
\hline \multirow[t]{3}{*}{ Gestão de Riscos } & A organização segue um programa inclusivo de gestão de riscos? \\
\hline & $\begin{array}{l}\text { Com que freqüência a liderança executiva revisa e atualiza o programa de } \\
\text { gestão de riscos e a cobertura do seguro? }\end{array}$ \\
\hline & $\begin{array}{l}\text { O conselho tem designado pessoas para falar oela organização no caso de } \\
\text { uma crise ou perda? }\end{array}$ \\
\hline \multirow{3}{*}{$\begin{array}{l}\text { Seleção, apoio e } \\
\text { avaliação da lideranç a } \\
\text { executiva }\end{array}$} & $\begin{array}{l}\text { O conselho definiu claramente o processo de busca da liderança executiva, } \\
\text { reservando tempo suficiente para recrutamento e entrevistas? }\end{array}$ \\
\hline & $\begin{array}{l}\text { O conselho provê o suporte que a liderança executiva necessita para cumprir } \\
\text { adequadamente as metas institucionais? }\end{array}$ \\
\hline & O conselho tem realizado a avaliação regular da liderança executiva? \\
\hline \multirow[t]{3}{*}{$\begin{array}{l}\text { Seleção e educação de } \\
\text { conselheiros }\end{array}$} & $\begin{array}{l}\text { O conselho tem um comitê de desenvolvimento que trabalha o ano todo para } \\
\text { melhorar o desempenho do grupo? }\end{array}$ \\
\hline & $\begin{array}{l}\text { Os novos conselheiros são recrutados com atenção e orientados com cuidado a } \\
\text { respeito da organização e das suas responsabilidades? }\end{array}$ \\
\hline & A maioria dos conselheiros respeita seus mandatos? Por quê? \\
\hline \multirow[t]{3}{*}{$\begin{array}{l}\text { Gestão e avaliação do } \\
\text { trabalho do conselho }\end{array}$} & $\begin{array}{l}\text { O conselho dedica a maior parte do seu tempo em questões de importância } \\
\text { para a organização? }\end{array}$ \\
\hline & $\begin{array}{l}\text { A estrutura do conselho e dos comitês contribui para a realização das suas } \\
\text { tarefas? }\end{array}$ \\
\hline & O conselho avalia o seu trabalho regularmente? \\
\hline
\end{tabular}

Para que um conselho seja capaz de cumprir com estes deveres e encontrar a forma mais adequada de operar é preciso, portanto, que ele compreenda claramente quais são as suas responsabilidades básicas uma vez tendo clara a tarefa que lhe é atribuída fica mais fácil definir como deve se organizar para exercêla.

\begin{abstract}
Porque a maneira pela qual um conselho pode se organizar de modo mais efetivo para exercer suas responsabilidades e exercer liderança é contingente em relação às características e valores do conselho e da organização, o principal desafio dos conselheiros é adotar práticas e políticas de governança que possibilitem ao conselho focar em questões críticas e alcançar os resultados desejados. ... não existem receitas infalíveis ou instruções técnicas para a governança institucional.
\end{abstract}

\title{
4.3.2 A NOVA FORMA DE TRABALHO DO CONSELHO
}

Taylor et allii (1996) ${ }^{70}$ utilizam-se da abordagem contingencial para caracterizar aquilo que chamam de "a nova forma de trabalho do conselho". Segundo eles, a nova forma de trabalho tem quatro características básicas:

70 TAYLOR, B.E., CHAIT, R.P. \& HOLLAND, T.P. The new work of the nonprofit board. Harvard Business Review, September-October, 1996. 
(a) Primeiro, concentra-se em questões cruciais, críticas e centrais para o sucesso institucional;

(b) Segundo, é orientada para resultados - resultados estes vinculados a cronogramas predefinidos;

(c) Terceiro, utiliza medidas claras de sucesso;

(d) Quarto, requer o engajamento tanto dos constituintes internos quanto externos da instituição.

Espera-se que a contribuição do conselho seja estratégica, o produto comum do trabalho de gente talentosa reunida para aplicar seu conhecimento e experiência nos maiores desafios com que se defronta a organização.

Segundo estes autores, a "nova forma" requer novas regras de envolvimento do conselho, bem como uma forma não ortodoxa de exercer as responsabilidades do conselho. As regras práticas para atuar nesta nova forma são:

I- Definir aquilo que é importante: para atuar de uma nova forma, os conselheiros e a liderança executiva juntos devem determinar os tópicos importantes e uma agenda para a entidade. Isso exige do conselho uma visão clara do contexto intra e extra institucional, que não pode ser construído a partir do ponto de vista de uma pessoa somente. O conselho pode solicitar que o principal executivo da organização dê a sua visão da situação e levantar questões sobre ela juntos, o conselho e o executivo precisam entrar em acordo sobre quais devem ser as prioridades e a direção estratégica da entidade. O conselho pode entrar em contato com as principais audiências, clientes e constituintes da instituição, construindo uma relação de comunicação de mão dupla. $O$ conselho pode consultar especialistas, do próprio conselho ou de fora, num esforço de aprender mais sobre a área de trabalho do empreendimento que governa e suas tendências. $\mathrm{O}$ conselho pode definir um número limitado de indicadores de desempenho, para suprir a eventual carência de dados e parâmetros de comparação.

II - $\quad$ Agir sobre o que é importa nte: nesta "nova forma de trabalho", conselho e equipe executiva estão do mesmo lado, atuando como parceiros tanto na definição de políticas como na sua implementação. A questão central é: o problema em questão é importante ou não, é central ou periférico? Pressupõe-se que assuntos importantes não podem ser sumariamente divididos em política e implementação - em crises, por exemplo, o envolvimento de conselheiros na ação pode ser criticamente importante, asseguram.

Muitas vezes a implementação é muito mais resultante do que a formulação.

III - Organizar-se sobre o que é importante: o conselho precisa se estruturar para lidar com as prioridades organizacionais; para que a nova forma de trabalho aconteça é preciso que o essencial determine a estrutura - comitês, grupos de trabalho, forças tarefas devem refletir as prioridades estratégicas da instituição. Estes grupos podem incluir conselheiros, pessoas da equipe executiva, especialistas e clientes, tendo um caráter temporário: multiplicam oportunidades para o surgimento de lideranças, dirigem o conselho para resultados e evitam o domínio de órgãos permanentes.

IV - Focar as reuniões sobre o que é importante: cada reunião precisa ser preparada considerando questões do tipo "Qual é o propósito desta reunião?", "Como deve ser organizada para conseguir isso?", separando claramente situações em que é necessária formação de imagem sobre um tema 
importante, das situações em que se busca alternativas de soluções para problemas difíceis, das crises e dos momentos delicados.

Os conselhos precisam utilizar diferentes formatos para propósitos diferentes. Usar aquilo que funciona.

Em síntese, na "nova forma de trabalho":

- Conselho e liderança executiva descobrem juntos o que é importante, mutuamente definem a agenda institucional e resol vem problemas em conjunto.

- Tanto o conselho como a liderança executiva definem e implementam políticas - a separação é imprecisa, os limites abertos - os domínios são decididos de acordo com o desafio em questão.

- A estrutura do conselho reflete as prioridades institucionais, valorizando a flexibilidade e sistemas ad hoc; os conselheiros podem ocupar posições múltiplas e criar diversos centros de ação.

- As reuniões são orientadas para resultados, com o protocolo variando conforme as circunstâncias ênfase deve ser dada àparticipação e àação.

- O conselho trabalha como uma equipe, escolhendo seus membros tanto pela personalidade individual como pela "química coletiva" - como um grupo, trabalha com acordos e capacita-se continuamente.

De fato, a flexibilidade exigida pela abordagem contingencial demanda uma capacidade maior de trabalho do conselho como grupo, um esforço colaborativo, sendo essa uma variável importante a ser considerada no processo de renovação, recrutamento e capacitação de conselheiros.

\subsection{ABORDAGEM POR COMPETÊNCIAS OU COMPORTAMENTAL}

CHAIT et alli (1996) investigaram, nos Estados Unidos da América, diversas questões a respeito da operação de conselhos de entidades sem fins lucrativos. Um dos livros que escreveram sobre o assunto, "The Effective Board of Trustees", foi baseado em experiências de 108 conselheiros e presidentes de organizações culturais e faculdades americanas. Após três anos de pesquisas eles concluíram que:

"Existem características e comportamentos específicos que distinguem conselhos fortes de conselhos fracos";

"Existe uma associação positiva e sistemática entre o desempenho do conselho, medido a partir de um conjunto de competências, e o desempenho das faculdades, medido a partir de uma série de indicadores financeiros convencionais".

Essa associação, conforme indicam os autores, não deve ser vista como causal. Eles não sugerem que, por exemplo, "conselhos das faculdades estudadas causam aumentos na receita operacional total ou na riqueza institucional". Eles descobriram, porém, que existe uma forte congruência entre competências de conselhos eficazes e um conjunto de indicadores de desempenho institucional.

O estudo de CHAIT et allii (1993) diferenciou -se por adotar uma abordagem que produzisse um resultado testado sistemática e empiricamente. Eles reuniram descrições altamente detalhadas do comportamento de conselhos e, ao analisá-los, foram capazes de determinar um conjunto de competências e habilidades 
associadas a esses comportamentos. Segundo os autores, "enquanto estudos anteriores se concentraram em como o jogo da governança era organizado, nós nos concentramos em como era executado". Um detalhe importante deste estudo é que foi focado no conselho como um grupo, considerando que "conselhos são, de fato, grupos".

Uma conclusão surpreendente a que chegaram CHAIT et allii (1996), em outro estudo com 6 escolas independentes, é a de que "o governo efetivo por um conselho diretor é um ato relativamente raro e nãonatural". Para eles, os conselheiros estão sempre sendo tentados a ser levados da estratégia para a operação, de desafios de longo prazo para preocupações imediatas, da ação coletiva para iniciativas individuais - o que exige que conselhos estejam sempre "lutando contra a corrente". A governança exercida por um conselho é definida por eles como "um esforço coletivo, através de processos cuidadosos e convenientes, de realizar ações que promovam um propósito compartilhado consistente com a missão da organização".

A partir das entrevistas com conselheiros e líderes institucionais estes autores verificaram a emergência de quatro reclamações recorrentes:

1. "Não existe conteúdo na mesa". As questões apresentadas ao conselho não são mais do que uma mistura de preocupações e questões triviais desconectadas umas das outras e da estratégia da instituição;

2. "As reuniões do conselho são chatas". As sessões são rigidamente preparadas, os resultados são fortemente predeterminados e as oportunidades de influenciar decisões são limitadas;

3. "Nós temos bastante informação, mas não temos idéia do que isto tudo significa". O material para o conselho vem repleto de dados brutos, sem interpretação, com os conselheiros se afogando em informação;

4. "A soma das partes deste conselho dá menos do que o todo". Os talentos individuais dos conselheiros não se submetem ao esforço coletivo. O conselho funciona mais como parceiros num jogo de golfe, do que como jogadores de um mesmo time.

A partir destas observações, CHAIT et allii (1996) chegaram a uma premissa fundamental: "O conselho como um todo tipicamente trabalha abaixo da sua capacidade e, de uma perspectiva institucional, um ativo potencialmente valioso é não utilizado".

Apesar disso, consideram que conselhos eficazes podem oferecer contribuições valiosas às suas organizações através de decisões e ações que melhoram, no longo prazo, a qualidade, a vitalidade e a estabilidade da instituição. Estas contribuições advêm pela adoção de pelo menos cinco práticas:

Prática 1: Ajudando a alta administração a determinar o que mais importa;

Prática 2: Criando oportunidades para o principal executivo "pensar em voz alta";

Prática 3: Encorajando a tentativa, a experimentação;

Prática 4: Monitorando progresso e desempenho;

Prática 5: Dando o exemplo de comportamentos desejados. 
Ao ajudar a alta administração a determinar as questões institucionais mais significativas, o conselho também precisa motivar, estimular ou dirigir seu principal executivo a tomar conta delas. Sempre existe o risco de achar que "tudo é mais importante", especialmente quando diferentes conselheiros têm diferentes pontos de vista que nunca são conciliados.

Ao criar oportunidades para o principal executivo da instituição "pensar em voz alta" o conselho estará criando uma oportunidade para si próprio de agregar valor, ao ajudar a melhorar e refinar as idéias daquele executivo. O conselho conseguirá isto ao criar uma atmosfera em que o diretor executivo possa falar livremente, com segurança e de forma íntima. O risco neste caso é o conselho partir direto para a formulação de políticas - o desafio é contribuir para que o executivo formule melhor os problemas e avalie valores básicos, riscos e ambigüidades da situação.

Encorajando a tentativa e a experimentação o conselho estará propiciando estímulo àmudança. Em alguns casos, a mudança pode acontecer porque o conselho define limites que forçam mudanças. Em outros, a mudança pode vir simplesmente em função de questões bem formuladas pelos conselheiros. Para encorajar a experiência, o conselho precisa pensar criativamente com a equipe executiva, definir políticas que exigem escolhas conscientes e algumas vezes levantar perguntas que ainda não foram feitas. Para promover o risco responsável, entretanto, é preciso que o conselho se preocupe em criar um ambiente seguro e que permita o erro.

O monitoramento do progresso e do desempenho de uma instituição sem fins lucrativos nem sempre é fácil, porque o conselho pode não saber como fazer isto e os indicadores podem não estar definidos ou serem difíceis de ser definidos. É preciso que o conselho se dedique a definir indicadores e meios para monitorar performance e desempenho. Ao colocar perguntas nesta direção o conselho pode gerar uma melhor definição dos resultados a serem alcançados, além de criar condições para antecipar conseqüências indesejáveis.

Espera-se que o conselho personifique os valores e objetivos da organização, dando exemplo de comportamentos desejados. Isto pressupõe consistência e sinceridade. Não basta apenas exigir que sejam implementadas modernas técnicas de gestão, se o próprio conselho não faz isto em æu trabalho. O alinhamento entre o comportamento dos conselheiros e os valores e políticas institucionais muitas vezes atrai atenção e pode trazer consideráveis benefícios àorganização.

Em outras palavras, conselhos não podem ser ao mesmo tempo paladinos da mudança e a personificação do status quo.

Abrangendo este conjunto de práticas e comportamentos, foram apresentados, por CHAIT et allii $(1993,1996)$, seis grupos de competências ou capacidades que diferenciam conselhos fortes de conselhos mais fracos. As competências básicas que distinguem conselhos mais fortes de conselhos mais fracos foram agrupados por estes autores conforme o quadro a seguir: 


\section{As Competências dos Conselhos Eficazes ${ }^{71}$}

\section{Dimensão Contextual}

O conselho entende e leva em consideração a cultu ra e as normas da organização que governa. O conselho:

$\diamond$ Adapta-se às características distintivas e àcultura do ambiente da o rganização.

$\diamond$ Baseia-se na missão, nos valores e na tradição da organização, usando-os como um guia para suas decisões.

$\diamond$ Age de modo a exemplificar e reforçar os valores da organização.

\section{Dimensão Educacional}

O conselho dá os passos necessários para assegurar que os conselheiros estejam instruídos a respeito da instituição, sua profissão e o papel, as responsabilidades e o desempenho do conselho. O conselho:

$\diamond$ Conscientemente cria oportunidades para a educação e o desenvolvimento dos conselheiros.

$\diamond$ Regularmente busca informação e retroalimentação sobre sua própria performance.

$\diamond$ Pára periodicamente para auto-reflexão, para diagnosticar seus pontos fortes e limitações e examinar seus erros.

\section{Dimensão Interpessoal}

O conselho cultiva o desenvolvimento dos conselheiros como um grupo de trabalho, dá atenção ao bem-estar coletivo do conselho e promove um senso de coesão. O conselho:

$\diamond$ Cria um senso de incl usão entre os conselheiros.

$\diamond$ Desenvolve metas grupais e reconhece as conquistas do grupo.

$\diamond \quad$ Identifica e cultiva liderança dentro do conselho.

\section{Dimensão Analítica}

O conselho reconhece as complexidades e sutilezas das questões e aceita ambigüidade e incerteza como pré-condições saudáveis para uma discussão crítica. O conselho:

$\diamond$ Aborda os assuntos da perspectiva de um conselho institucional.

$\diamond$ Disseca e examina todos os aspectos das questões multifacetadas.

$\diamond$ Levanta dúvidas, explora conseqüências e encoraja a expressão de diferenças de opiniões.

\footnotetext{
${ }^{71}$ In: CHAIT, R., HOLLAND, T.P. \& TAYLOR, B.E., Improving the performance of governing boards. EUA: The Oryx Press, 1996.
} 


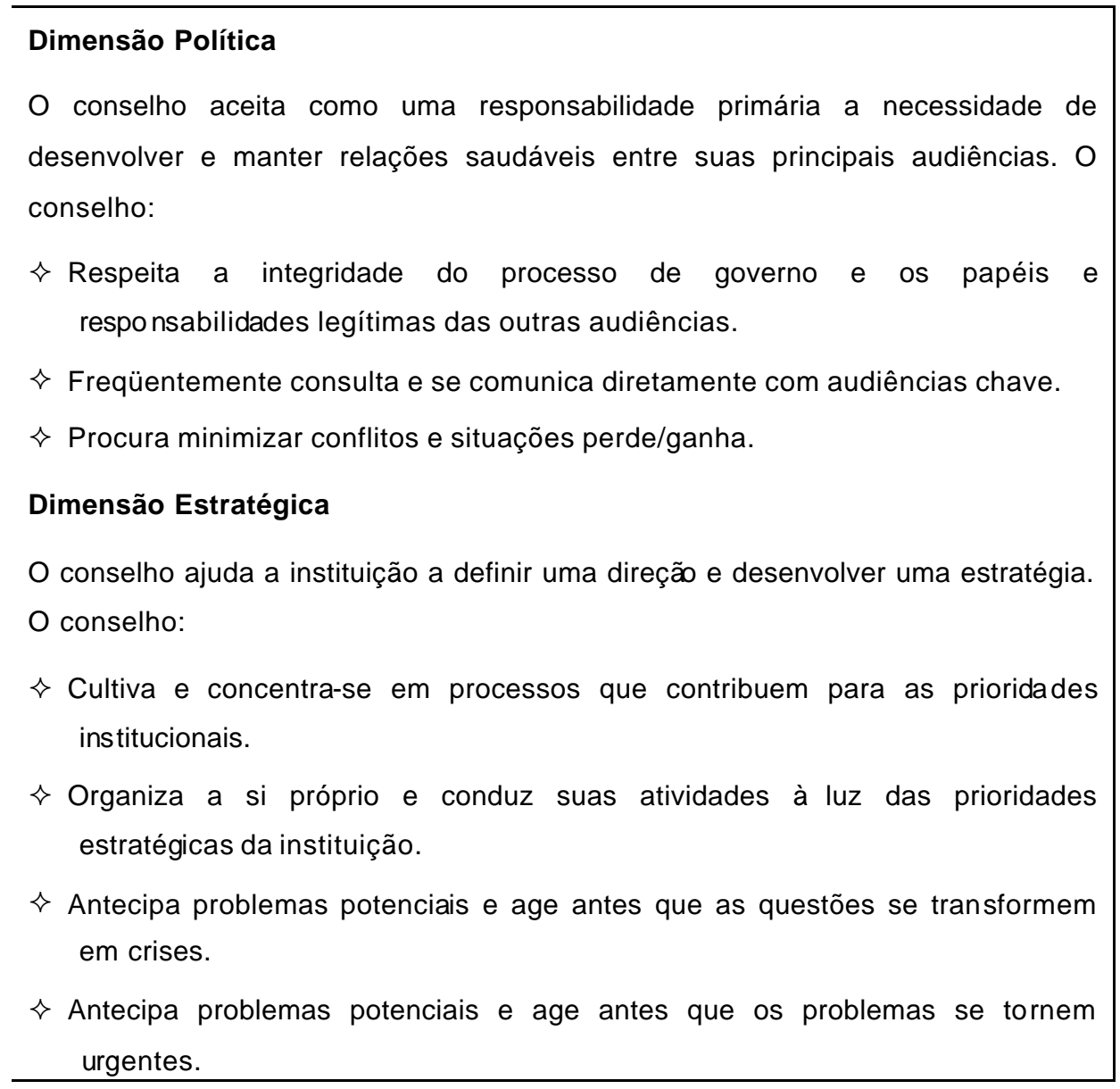

Este modelo baseado em competências pode ser usado como referência para diagnóstico e análise do comportamento do conselho, bem como para avaliar seu desempenho e orientar um processo de renovação. Ele contém, afirmam o autores, os conjuntos de capacidades que um conselho precisa ter para governar bem.

De fato, o modelo provou ser igualmente aplicável a escolas independentes, hospitais, agências de serviço social e organizações culturais.

A seguir é feita uma breve descrição de cada uma das dimensões destas competências.

A Dimensão Contextual pressupõe que conselhos efetivos são sensíveis e adaptam-se às características distintivas do ambiente e da cultura organizacional. Enquanto que conselhos pouco eficazes têm pouca disposição para "aclimatar-se", conselhos eficazes reconhecem e adaptam -se às idiossincrasias locais. Enquanto conselhos mais fracos pressionam para injetar práticas empresariais" esperando modificar a cultura institucional para aquela a que estão mais acostumados, conselhos mais fortes buscam aprender uma nova cultura de trabalho. Isso significa que conselhos mais eficazes tendem a compreender os ingredientes de um comportamento "apropriado" para a organização, para tornar-se melhor preparados para decidir quando e onde agir diferentemente.

A Dimensão Contextual pressupõe que conselhos eficazes orientam-se pela missão, tradição e história da instituição. Enfatiza-se que o conselho tem um papel de guardião da missão institucional, bem como um entendimento profundo e compartilhado dela. Em conselhos pouco eficazes é freqüente encontrar membros 
que mal conseguem articular a missão e que tampouco conseguem listar um conjunto de características distintivas da entidade. Conselhos fracos tendem a discutir propostas unicamente sob a perspectiva do mercado e da situação financeira, sem qualquer referência à missão ou à visão institucional mais profunda. Conselhos mais fortes começam com a missão e preocupam-se primeiro com a pergunta "Por que estamos aqui?", clarificando propósitos e prioridades, dando primeiro significado àquilo que a organização faz.

Dentro da Dimensão Contextual ainda, as decisões de conselhos mais eficazes refletem e reforçam valores institucionais. Para estes conselhos, são os valores que dão forma às políticas, estratégias e táticas organizacionais - eles são capazes de enumerar de pronto uma série de valores, o que já não acontece com conselhos mais fracos. Os melhores conselhos consideram a importância e praticam atos simbólicos que refletem os valores institucionais, "praticando o que pregam". Conselhos mais fracos tendem a negligenciar ou mesmo questionar a relação entre valores institucionais e comportamento do conselho.

Pela Dimensão Educacional espera-se que conselhos competentes criem várias oportunidades para formação dos conselheiros. Pressupõe-se que conselhos têm muito a aprender. Em conselhos menos competentes os conselheiros são os últimos a serem cogitados para capacitação e treinamento. Nestes conselhos assume-se que as experiências e conhecimentos anteriores de cada membro são suficientes para tornálos bons conselheiros. Toda preparação é informal e ao acaso. Em conselhos mais fortes esperase que as lideranças assumam um papel de formadores e educadores. $O$ processo educacional apenas inicia-se com a orientação aos conselheiros, sendo visto como algo contínuo e que desenvolve-se em várias instâncias.

Conselhos eficazes periodicamente engajam -se em processos de auto-reflexão e solicitam retroalimentação sobre seu desempenho, muitas vezes utilizando retiros e oficinas de trabalho. Conselhos mais fracos passam anos sem nem mesmo tentar provocar um processo de auto-avaliação. Quase não há mecanismos de avaliação ou retroalimentação, nem nas reuniões. Os melhores conselhos exercitam a autocrítica como fator de melhoria da qualidade do trabalho que faz - e consideram que esta auto-avaliação dá legitimidade à recomendação de avaliação pela equipe técnica/executiva também.

Conselhos eficazes usam seus erros para aprender, enquanto conselhos ineficazes preferem ignorá-los ou esquecê-los. Conselheiros de bons grupos são capazes, voluntariamente, de relacionar e descrever erros cometidos (e lições aprendidas), enquanto seus colegas de grupos mais fracos não se lembram de erros que fizeram ou citam coisas isoladas e menores. Bons conselhos fazem esforços intencionais para aprimorar sua prática.

A Dimensão Interpessoal pressupõe que o conselho, como grupo, desenvolve-se. As decisões, num bom conselho, são tomadas em grupo, não individualmente. Esta dimensão geralmente é complicada pelo fato de muitas vezes os membros de conselhos serem estranhos ou pouco familiarizados entre si. Mesmo assim, um bom conselho tende a ser um bom grupo.

Em grupos mais desenvolvidos cria-se um senso de inclusão entre seus membros, havendo maior informalidade nas relações e maiores esforços de comunicação entre todos. Enfatiza-se participação, compromisso e envolvimento. Reconhecese que o fluxo de informações e os padrões de comunicação dentro do conselho são variáveis particularmente críticas que afetam o senso de envolvimento de cada membro. Em conselhos menos eficazes comumente existem normas (explícitas ou implícitas) que 
restringem a participação e limitam as discussões, predominando relações verticais e formais, evitando-se questões polêmicas e tensões.

Bons conselhos definem objetivos para si próprios, enquanto que grupos mais fracos costumam apenas assumir tarefas genéricas ou não assumir nada. Bons conselhos desenvolvem um senso de propriedade e responsabilidade pelas metas que emergem, existindo um plano para o próprio conselho. Conselhos pouco eficazes geralmente enfatizam esforços individuais.

Em conselhos mais desenvolvidos há uma preocupação em preparar membros para posições futuras de liderança e em planejar o processo sucessório. Ao contrário, conselhos ineficazes tendem a ser indiferentes àquestão e freqüentemente dependentes da principal liderança executiva.

A Dimensão Analítica das competências leva bons conselhos a olhar os fatos sob várias lentes diferentes e a considerar que a maioria das questões com que lidam é complicada e precisa ser examinada a partir de diferentes perspectivas. Conselhos competentes estão mais inclinados a pensar "ambos/e" do que "nenhum/ou" e a descrever ações com múltiplos objetivos derivados do uso de múltiplas referências. Por outro lado, conselhos menos competentes raramente admitem o conteúdo altamente simbólico das diversas formas de comunicação.

Conselhos eficazes percebem sutilezas e nuanças, oferecendo respostas mais profundas a questões aparentemente simples, como papel do conselheiro ou do presidente. Conselheiros são considerados membros de um grupo que adota uma perspectiva institucional ampla e exercita autoridade limitada, muitas vezes influenciando eventos indiretamente. Membros de conselhos menos eficazes apenas oferecem respostas estreitas e algumas vezes simplistas a algumas questões, como, por exemplo, o papel do presidente do conselho.

Em seu estudo, CHAIT et allii (1996) asseveram que conselhos com competência analítica estão muito mais abertos a levantar dúvidas, explorar dimensões desfavoráveis e tratar de perdas, estando as questões na mesa abertas à análise e discussão. Conflitos de opinião são considerados bem -vindos e mesmo encorajados em discussões em pequenos grupos. Por outro lado, em conselhos menos competentes, a equipe executiva e os próprios conselheiros apresentam informações, relatórios e recomendações com tanta certeza e convicção que esfriam qualquer debate - espera-se que os conselheiros apenas endossem as recomendações com pouca ou nenhuma conversação ou dissenso.

Por Dimensão Política entende-se a habilidade de desenvolver e manter relacionamentos saudáveis com audiências chave. Instituições são sistemas políticos complexos, onde vários constituintes sustentam poder e influência. Conselhos eficazes respeitam a integridade do processo de governança, provendo orientação através de indagações, discussões, pedidos de informação e tentativas para chegar a compromissos razoáveis - respeitando e mantendo-se dentro da missão da instituição. Membros de conselhos ineficazes parecem ser menos sensíveis às características da política institucional, muitas vezes conhecendo pouco quem são as audiências da organização e o que pensam - eles identificam, por exemplo, apenas aquelas audiências com as quais o conselho tem relação direta.

Conselhos eficazes assumem responsabilidade pela qualidade dos relacionamentos entre as múltiplas audiências, enquanto que conselhos ineficazes tendem a ser mais indiferentes a isso e concentrar-se nas relações diretas dos conselheiros. Conselhos eficazes tentam maximizar a comunicação e as consultas aos 
diversos públicos da entidade, in teragindo regularmente com eles. Conselhos ineficazes fazem justamente o oposto: conselheiros neste caso são geralmente relutantes em ter contato direto com estes públicos, deitando extrema dependência naquilo que a equipe executiva conta e informa.

Processos decisórios são conduzidos com lentidão, quando necessário, por conselhos mais eficazes - como forma de formar consensos e evitar ações e decisões que ameacem dividir o conselho ou a própria instituição. Estes conselhos evitam apressar decisões ou excluir opções em questões políticas cruciais, procurando trabalhar em conjunto nos problemas e minimizar (ao invés de reprimir) resistências. Conselhos ineficazes aparentemente assumem que a resposta mais apropriada para diferenças de opinião é a votação - que freqüentemente gera vencedores e perdedores.

A Dimensão Estratégica diz respeito à habilidade que o conselho tem de construir uma visão institucional e dar direção à organização. Assim, os melhores conselhos dedicam-se à estratégia organizacional, concentrando-se em algumas poucas questões cruciais - o tempo e a atenção do conselho são considerados como recursos escassos. Conselhos pouco eficazes, ao contrário, têm pouco senso de propósito e prioridade, utilizando boa parte do seu tempo com questões comparativamente pouco importantes e assuntos de rotina. Em conselhos frágeis estas questões estão relacionadas à sobrevivência ou ao crescimento da organização. CHAIT et allii (1993) afirmam que em muitos conselhos pouco competentes "o orçamento determina as prioridades", enquanto que uma perspectiva mais estratégica deve considerar que as prioridades determinam o orçamento. Resumindo, conselhos ineficazes normalmente são incertos quanto às prioridades institucionais, enquanto que conselhos fortes asseguram que exista um processo - focado, inclusivo e abrangente - em curso para identificar e perseguir as prioridades da organização.

Antecipar problemas e agir antes que as questões tornem-se urgentes também são atitudes inerentes a conselhos eficazes. Estes conselhos contribuem para a liderança estratégica através de informação, discernimento e questionamento, sendo orientados para a ação e para o futuro, assumindo riscos e responsabilidades. Seus pares menos eficazes se preocupam com questões mais prementes e operam de forma a desencorajar o surgimento de questões, dúvidas e preocupações. 


\section{QuARTA PaRte: Buscando lições em eXPERIÊnCIAS BRASILEIRAS}

Tendo como pano de fundo as referências conceituais citadas anteriormente, busca-se deste ponto em diante examinar a atuação de conselhos formalmente constituídos nas entidades objeto desta pesquisa: dez organizações da sociedade civil participantes da Rede Nossas Crianças.

A primeira pergunta é: quantas organizações da Rede têm conselhos?

\subsection{Perfil estatutário das organizações da Rede Nossas Crianças}

Para caracterizar o universo formal das organizações participantes da Rede Nossas Crianças foi feito um levantamento do perfil de 66 entidades $^{72}$, com base em seus estatutos, no segundo semestre do ano 2000.

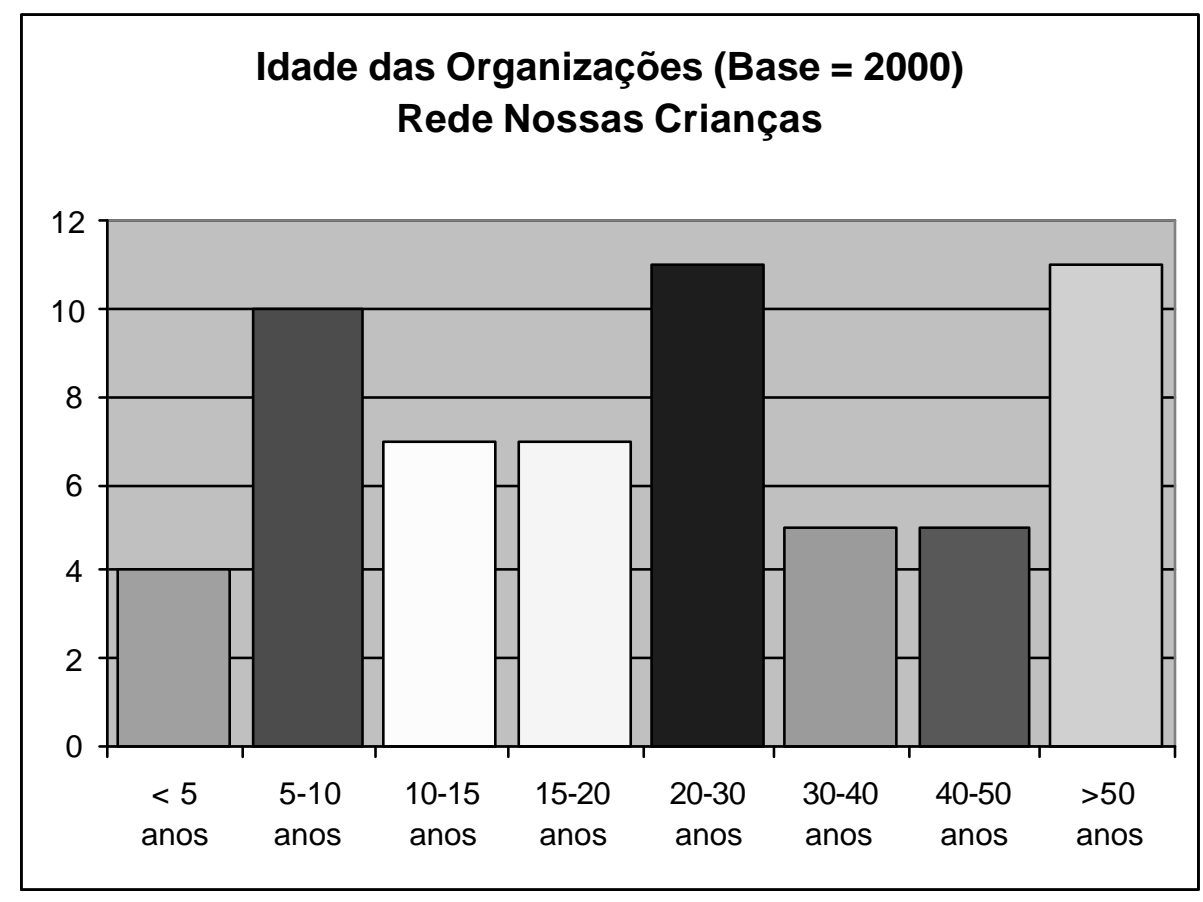

O levantamento revelou as seguintes características principais da Rede Nossas Crianças:

- 42 entidades (64\%) mantinham convênio com a Fundação Abrinq;

- 50 delas (77\%) têm mais de 10 anos de existência e 11 (18\%) têm mais do que 50 anos;

- O tempo de existência médio destas entidades é de 29 anos;

- 43 entidades (65\%) mantêm um centro de educação de adolescentes e 39 entidades (59\%) têm creches;

\footnotetext{
${ }^{72}$ Não inclui a Fundação Abrinq.
} 
- 28 entidades (42\%) se localizam na Zona Sul da Grande São Paulo e apenas 2 (3\%) se localizam no Centro;

- Um terço dos estatutos (21) foram alterados há menos de 5 anos e 45 entidades (70\%) os alteraram nos últimos 10 anos;

- 6 entidades (9\%) mantêm os mesmos estatutos há mais de 20 anos.

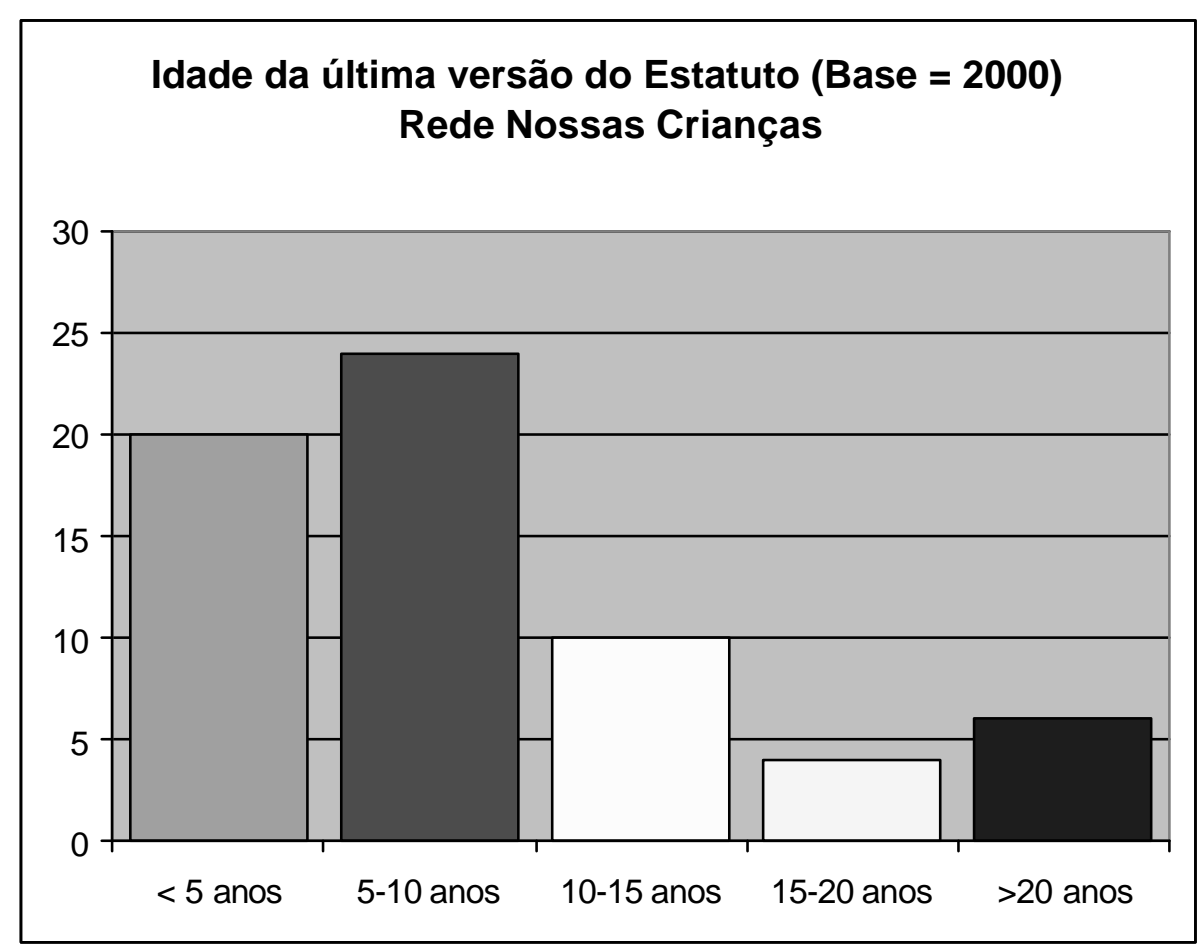

O levantamento dos órgãos responsáveis pela administração, conforme consta nos estatutos, mostrou que:

- 59 entidades (89\%) mencionam a existência de uma assembléia geral nos seus estatutos;

- 62 entidades (94\%) possuem algum tipo de diretoria;

- 31 entidades (47\%) possuem algum tipo de conselho definido em seus estatutos, não incluídos nestes os conselhos fiscais;

- 10 entidades (15\%) possuem um conselho deliberativo, 3 (5\%) possuem um conselho de administração e $4(6 \%)$ possuem um conselho diretor;

- 9 entidades (14\%) possuem um conselho consultivo;

- 8 entidades (12\%) possuem mais de um conselho (sem contar o fiscal);

- 55 entidades (83\%) possuem um conselho fiscal.

Estes dados permitem inferir que em geral as organizações da Rede Nossas Crianças têm uma história significativa de vida (pelo menos 10 anos) e vêm trabalhando no regime legal tradicional, possuindo como órgãos dirigentes principais a diretoria (voluntária), a assembléia geral e o conselho fiscal. Essas organizações dedicam alguma atenção à atualização dos seus estatutos, que acontece em períodos 
plurianuais. A inserção de conselhos nos estatutos parece ser uma prática conhecida, embora não predominante na Rede.

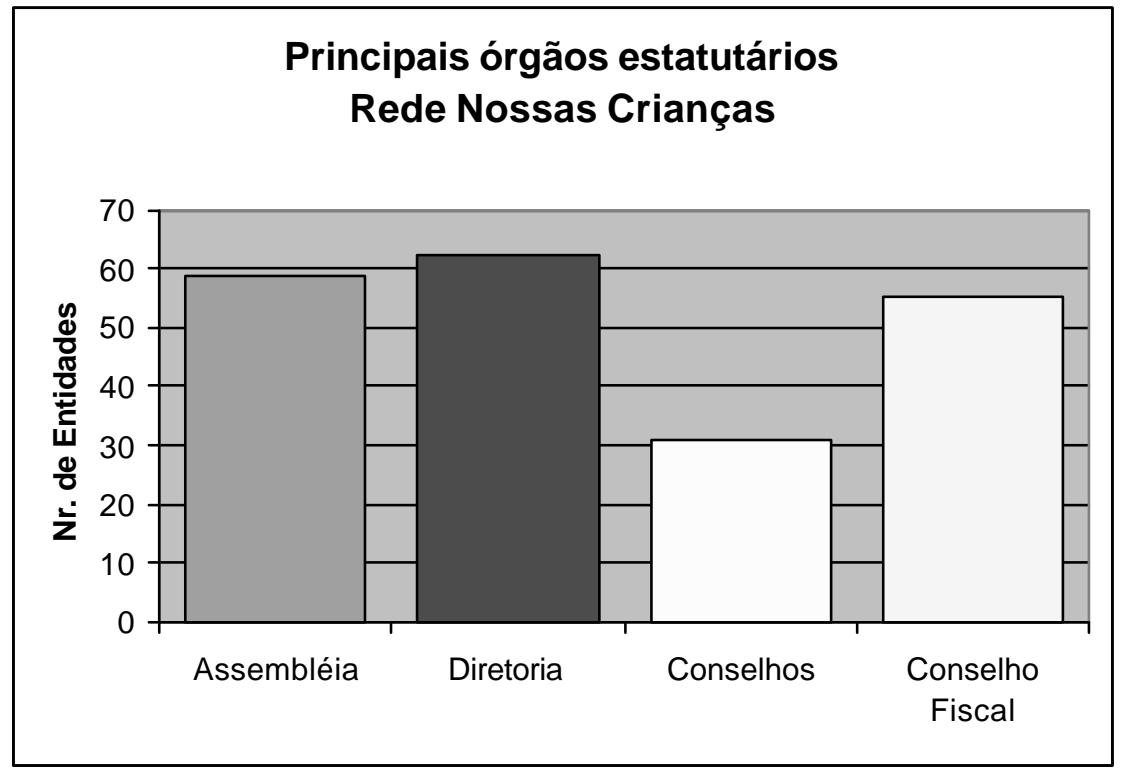

\subsection{Perfil das organizações estudadas}

As 10 organizações da Rede Nossas Crianças que participaram desta pesquisa tinham o seguinte perfil:

- A mais velha foi fundada há 58 anos atrás, enquanto a mais jovem foi fundada há apenas 2 anos;

- 6 organizações têm mais de 10 anos e o tempo de existência médio foi de 20 anos;

- As 10 organizações juntas beneficiam cerca de 820.000 pessoas (segundo inform ações delas próprias), sendo que duas entidades respondem por $99,8 \%$ deste número - as outras 8 organizações beneficiam em média 539 pessoas cada uma;

- A organização que realiza o menor atendimento beneficia diretamente 120 clientes;

- O orçamento anual deste conjunto de entidades ultrapassa $R \$ 19$ milhões de reais, porém 7 organizações têm um orçamento anual menor do que $\mathrm{R} \$ 1$ milhão de reais;

- O menor orçamento anual é de $R \$ 276.000,00$;

- 6 instituições operam apenas uma unidade de atendimento;

- As 10 organizações juntas empregam 855 funcionários - a que emprega menos tem 17 funcionários e a que emprega mais tem 283 funcionários;

- 4 organizações já receberam o Prêmio Bem Eficiente entre 1997 e 2001 e 6 são conveniadas à Fundação Abrinq;

- 9 entidades têm um site na Internet, 7 mantêm um vídeo institucional, 5 fazem relatório anual, 9 têm registro de utilidade pública municipal, 7 têm título de utilidade estadual e 9 têm título de utilidade federal; 
- 4 dessas entidades têm um conselho de administração, 3 têm um deliberativo, 3 têm um conselho consultivo, 1 tem um conselho diretor e 1 tem um conselho curador;

- 2 entidades têm mais de um conselho;

- Este conjunto de entidades mobiliza (intensivamente ou não) pelo menos 156 conselheiros, tendo 16 pessoas em média em cada conselho (um mínimo de 5 e um máximo de 33);

- 9 das organizações adotam mandatos menores ou iguais a 3 anos;

- 7 conselhos se reúnem 4 ou mais vezes por ano.

Os gráficos abaixo dão outras informações:

\section{Localização das entidades da amostra \\ Região da Grande São Paulo}

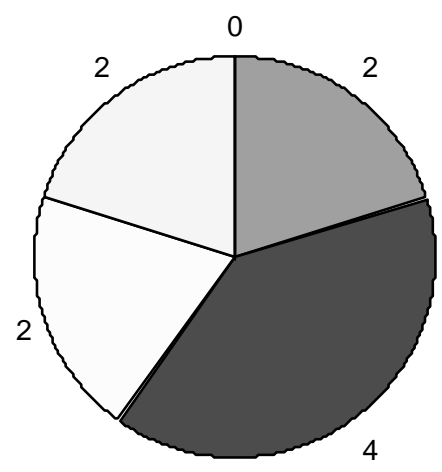

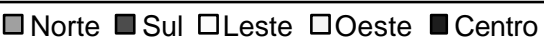



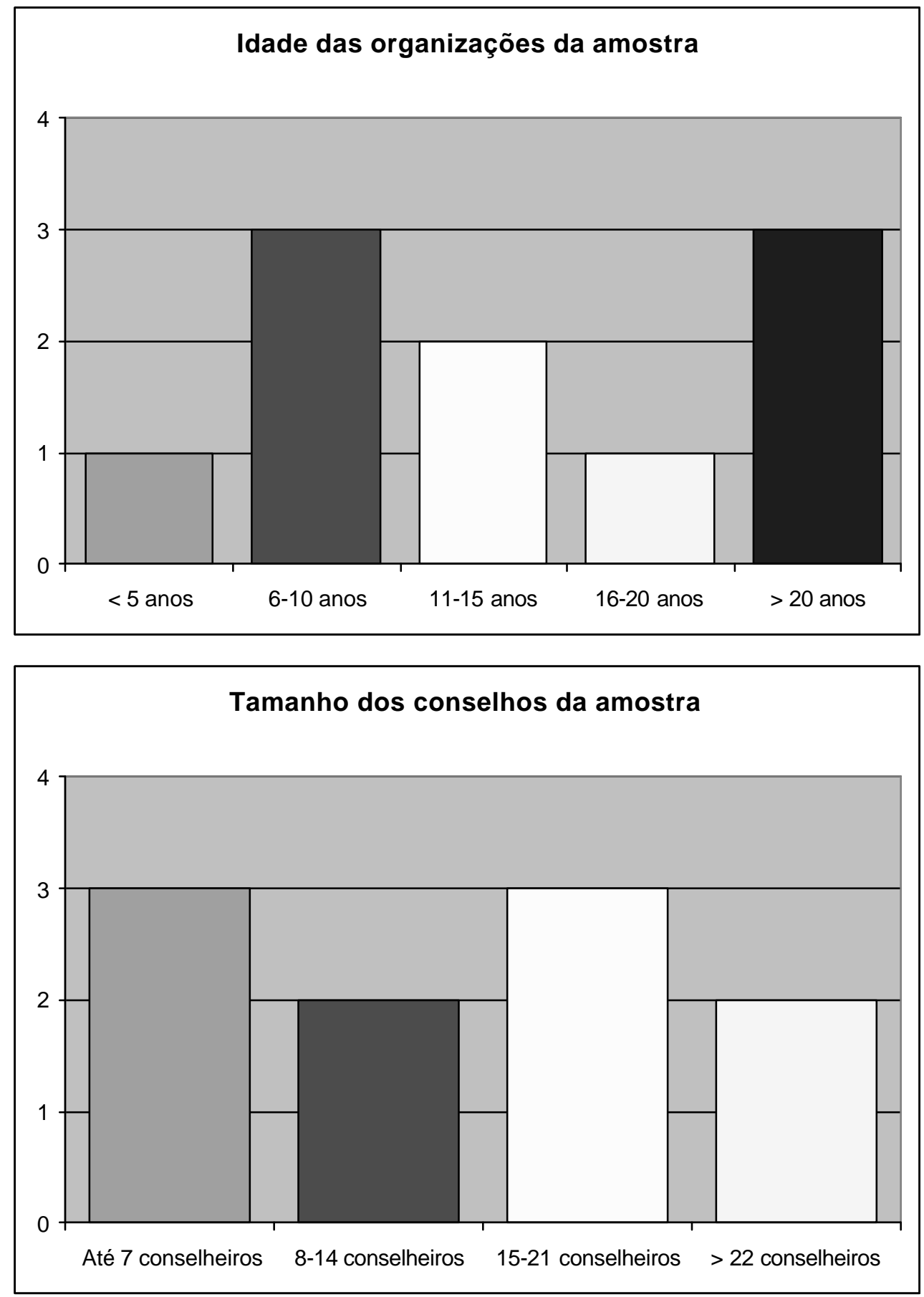


\section{Orçamento anual das entidades da amostra}

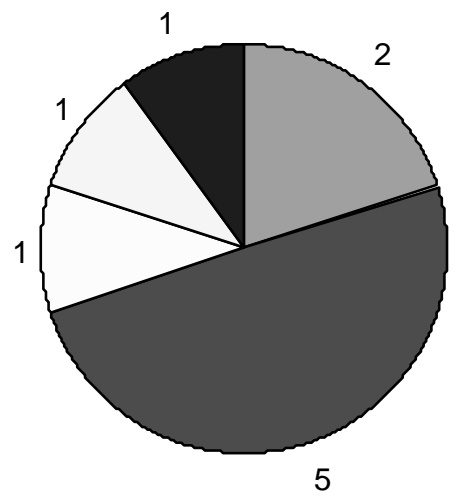

$\square$ Até $\mathrm{R} \$ 500 \mathrm{mil} \quad \square \mathrm{R} \$ 500-1000 \mathrm{mil} \quad \square \mathrm{R} \$ 1000-2000 \mathrm{mil}$ $\square R \$ 2000$ - 5000 mil $\square>\mathrm{R} \$ 5000 \mathrm{mil}$

\subsection{Perfil dos conselheiros e eXeCUTIVOS entreVISTAdOS}

Durante a pesquisa foram entrevistados 11 membros dos conselhos. Este grupo apresentou como características principais:

- Idade média de 56 anos, sendo que o mais jovem tinha 24 anos e o mais velho tinha 82 anos;

- Eram 6 mulheres e 5 homens;

- Pelo menos 7 tinham formação superior;

- O "tempo de casa" organizacional era de no mínimo 4 anos, para uma média de 21 anos, sendo que 6 estavam na organização há mais de 10 anos;

- Todos dedicavam -se voluntariamente à organização;

- 7 conselheiros dedicavam menos de 8 dias por mês àorganização.

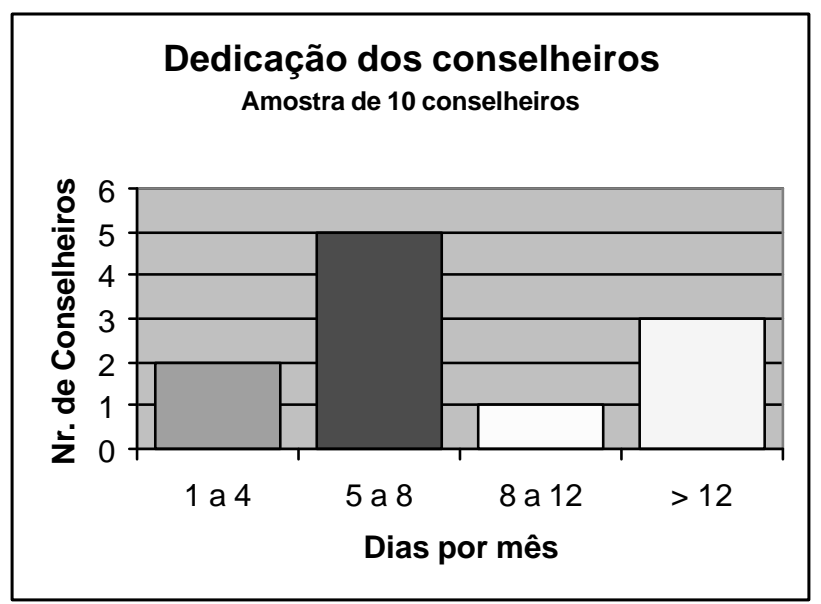




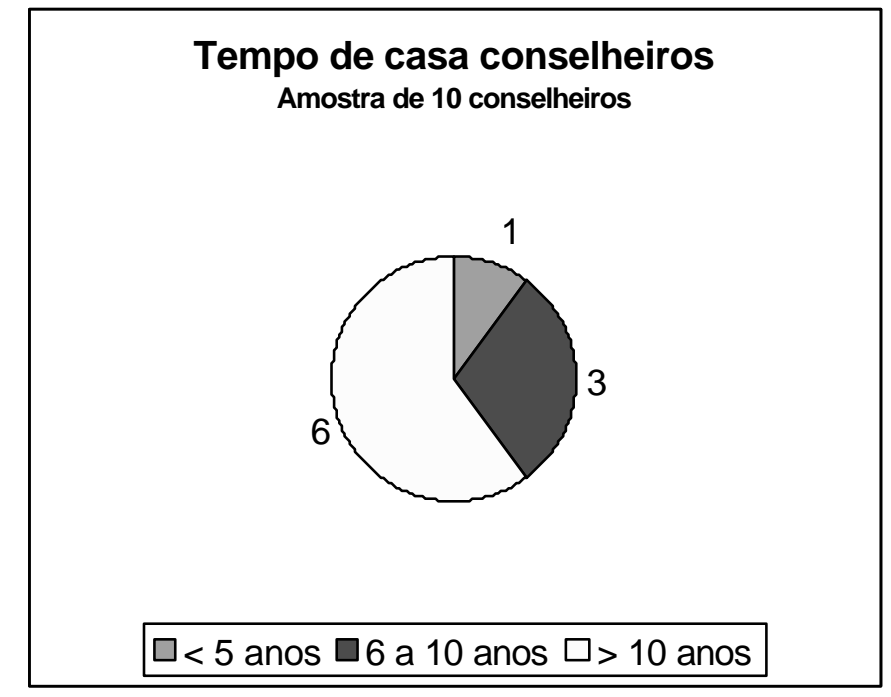

O grupo de lideranças executivas apresentou o seguinte perfil:

- Idade média de 51 anos, sendo que o mais jovem tinha 31 anos e o mais velho 66;

- 9 eram mulheres e apenas um era do sexo masculino;

- 7 tinham formação superior;

- O "tempo de casa" médio das executivas foi de 16 anos, sendo que 5 delas estavam na organização há mais de 10 anos (destas, 3 estavam há mais de 20 anos);

- 6 delas recebiam remuneração para trabalhar na organização e uma era cedida por um órgão público;

- 9 dedicavam-se praticamente em tempo integral, àorganização.

\section{Tempo de casa das executivas \\ Amostra de 10 executivas}

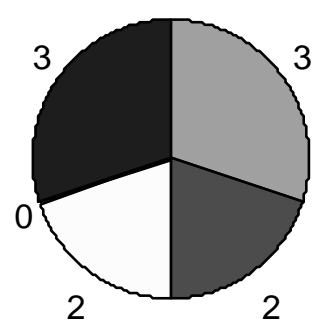

$\square<5$ anos $\square 6$ a 10 anos $\square 11$ a 15 anos $\square 16$ a 20 anos $\square>20$ anos

A comparação entre o perfil dos membros dos conselhos e das lideranças executivas mostra que em média os conselheiros são mais velhos, embora em termos de idade a amplitude seja maior. O grupo de conselheiros apresenta uma maior heterogeneidade também em termos de gênero (maior equilíbrio en tre homens e mulheres). Como era de se esperar, o vínculo dos dois grupos com suas organizações é bastante 
diferente, pois os conselheiros são majoritariamente voluntários e os executivos remunerados. A dedicação evidentemente dos executivos é muito maior que dos conselheiros, denotando uma ligação com as questões do dia-a-dia. O "tempo de casa" dos dois grupos pode ser considerado alto, especialmente dos conselheiros, podendo indicar dificuldades de renovação e possível presença de fundadores nestes grupos (o que vai ser discutido mais adiante).

\subsection{DesempenHo GERAL dos ConselHOS - ANÁLISE dOS QuestionÁRIOS}

Foram aplicados questionários de avaliação do desempenho do conselho em 20 dos 21 entrevistados, dos quais metade eram conselheiros e metade lideranças executivas. A pontuação média foi de $64 \%$, entre um máximo de $91 \%$ e um mínimo de $43 \%$ - lembrando que as pontuações percentuais representam as seguintes situações:

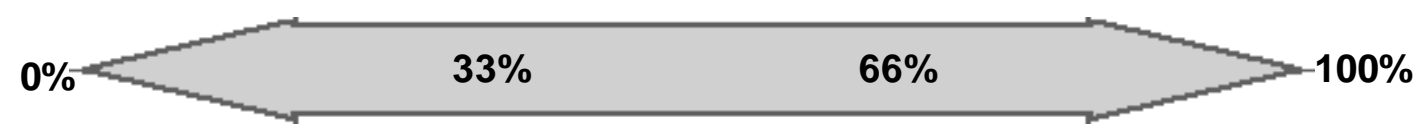

\begin{tabular}{|c|c|c|}
\hline $\begin{array}{l}\text { Prática } \\
\text { nunca } \\
\text { adotada }\end{array}$ & $\begin{array}{l}\text { Prática } \\
\text { raramente } \\
\text { adotada }\end{array}$ & $\begin{array}{c}\text { Prática } \\
\text { freqüentemente } \\
\text { adotada }\end{array}$ \\
\hline
\end{tabular}

A pontuação de cada uma das instituições está apresentada no quadro abaixo:

\begin{tabular}{|c|c|c|c|c|c|c|c|}
\hline \multicolumn{8}{|c|}{ Score Organizacional - Resumo } \\
\hline Entidade & $\begin{array}{c}\text { Pontuação } \\
\text { geral }\end{array}$ & $\begin{array}{c}\text { Competência } \\
\text { Analítica }\end{array}$ & $\begin{array}{c}\text { Competência } \\
\text { Contextual }\end{array}$ & $\begin{array}{l}\text { Competência } \\
\text { Educacional }\end{array}$ & $\begin{array}{c}\text { Competência } \\
\text { Estratégica }\end{array}$ & $\begin{array}{l}\text { Competência } \\
\text { Interpessoal }\end{array}$ & $\begin{array}{c}\text { Competência } \\
\text { Política }\end{array}$ \\
\hline 4 & $91 \%$ & $83 \%$ & $93 \%$ & $96 \%$ & $90 \%$ & $89 \%$ & $92 \%$ \\
\hline 1 & $78 \%$ & $63 \%$ & $86 \%$ & $68 \%$ & $75 \%$ & $86 \%$ & $89 \%$ \\
\hline 5 & $73 \%$ & $74 \%$ & $71 \%$ & $51 \%$ & $78 \%$ & $78 \%$ & $85 \%$ \\
\hline 7 & $64 \%$ & $69 \%$ & $76 \%$ & $49 \%$ & $63 \%$ & $68 \%$ & $60 \%$ \\
\hline 3 & $63 \%$ & $68 \%$ & $81 \%$ & $36 \%$ & $61 \%$ & $63 \%$ & $72 \%$ \\
\hline 2 & $63 \%$ & $63 \%$ & $74 \%$ & $53 \%$ & $51 \%$ & $68 \%$ & $71 \%$ \\
\hline 10 & $63 \%$ & $57 \%$ & $72 \%$ & $40 \%$ & $71 \%$ & $74 \%$ & $64 \%$ \\
\hline 8 & $54 \%$ & $56 \%$ & $51 \%$ & $39 \%$ & $54 \%$ & $64 \%$ & $60 \%$ \\
\hline 9 & $49 \%$ & $54 \%$ & $58 \%$ & $38 \%$ & $46 \%$ & $44 \%$ & $56 \%$ \\
\hline 6 & $43 \%$ & $49 \%$ & $47 \%$ & $22 \%$ & $43 \%$ & $39 \%$ & $56 \%$ \\
\hline Média & $64 \%$ & $63 \%$ & $71 \%$ & $49 \%$ & $63 \%$ & $67 \%$ & $70 \%$ \\
\hline Mínimo & $43 \%$ & $49 \%$ & $47 \%$ & $22 \%$ & $43 \%$ & $39 \%$ & $56 \%$ \\
\hline Máximo & $91 \%$ & $83 \%$ & $93 \%$ & $96 \%$ & $90 \%$ & $89 \%$ & $92 \%$ \\
\hline Desvio padrão & $14 \%$ & $10 \%$ & $15 \%$ & $20 \%$ & $15 \%$ & $16 \%$ & $14 \%$ \\
\hline Variância & $2 \%$ & $1 \%$ & $2 \%$ & $4 \%$ & $2 \%$ & $3 \%$ & $2 \%$ \\
\hline Máx - Mín = & $48 \%$ & $35 \%$ & $46 \%$ & $74 \%$ & $47 \%$ & $50 \%$ & $36 \%$ \\
\hline
\end{tabular}




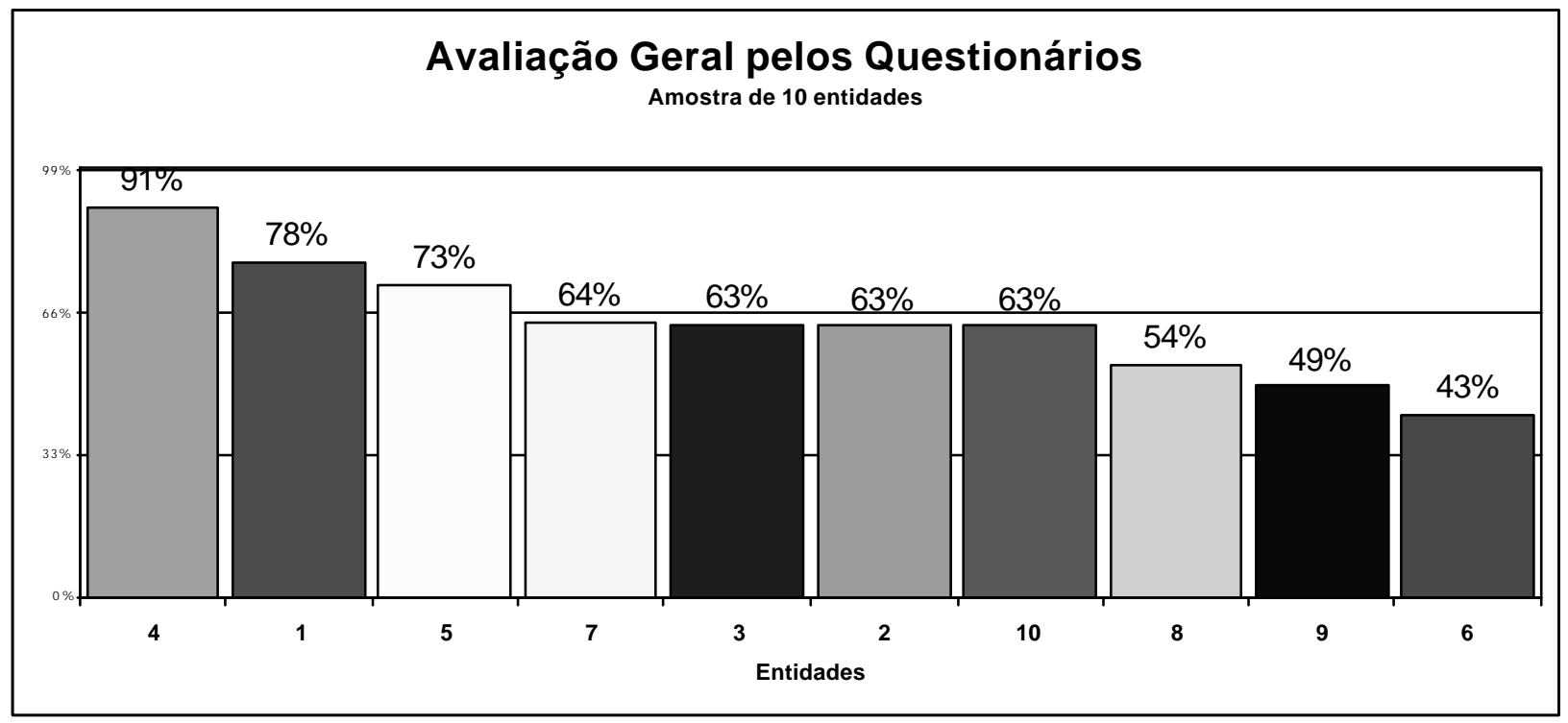

Este quadro, longe de demonstrar qual é o melhor ou o pior conselho, dá uma indicação de quais, na opinião dos entrevistados, são as competências predominantes no conjunto de conselhos estudados e quais são, a princípio, menos desenvolvidas. Considerando a somatória de pontos, os conselhos foram melhor avaliados nas competências contextual e política, sendo que na competência política a amplitude das avaliações também foi uma das menores. Em quatro casos a pontuação mais alta se referiu à competência contextual e em três casos à competência política. É interessante notar que nas três organizações que tiveram as maiores pontuações (acima da média) os fundadores ainda estão presentes, sugerindo uma possível relação entre a presença dos pioneiros e as competências contextual e política. Porém, as duas organizações mais velhas tiveram como competência melhor avaliada a contextual, indicando que a competência contextual não está somente vinculada àpresença de fundadores.

As avaliações mais fracas recaíram sobre a competência educacional, que em 7 casos recebeu a pior pontuação, sugerindo que os conselhos das organizações estudadas preocupam-se pouco com sua própria formação e desenvolvimento. 


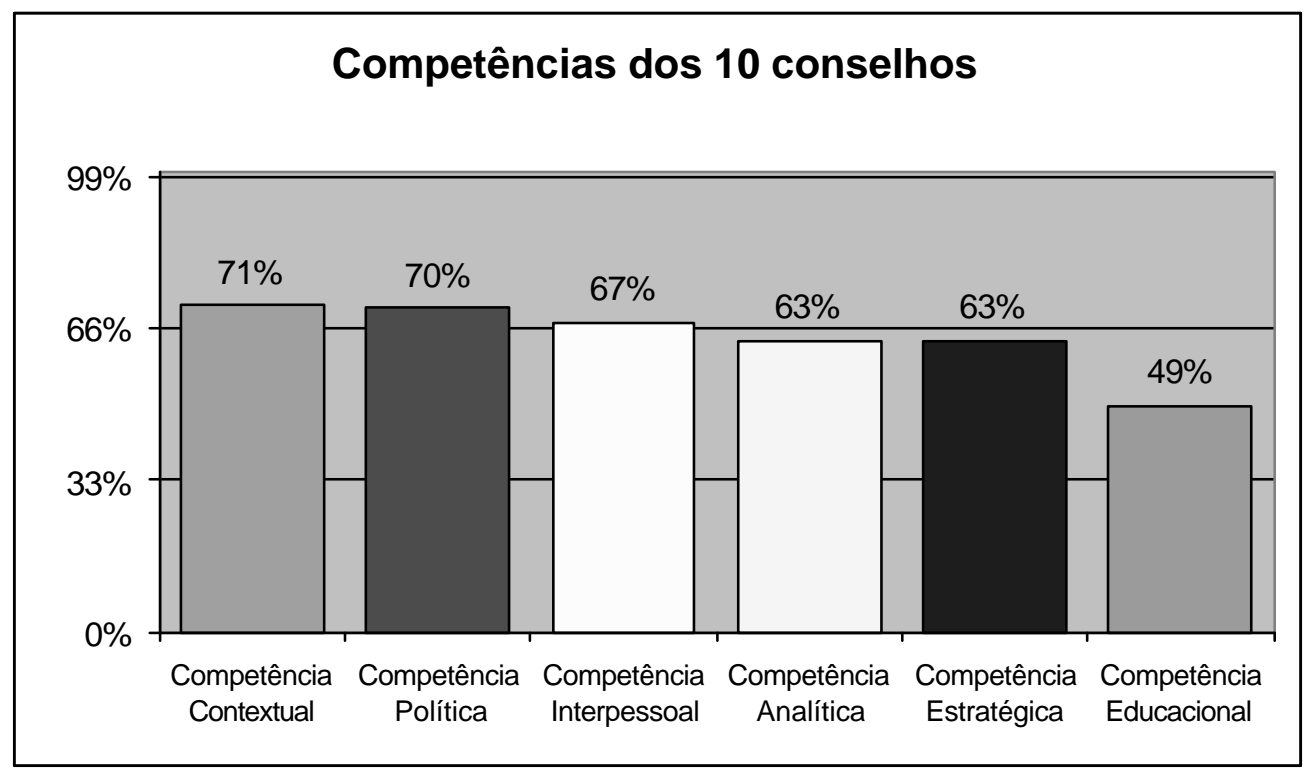

As competências analítica e estraégica situam-se num estágio intermediário - em dois casos a pior pontuação foi para a primeira e em um caso foi para a segunda. A competência interpessoal recebeu a maior pontuação em dois casos, não ficando pior pontuada em nenhuma instituição.

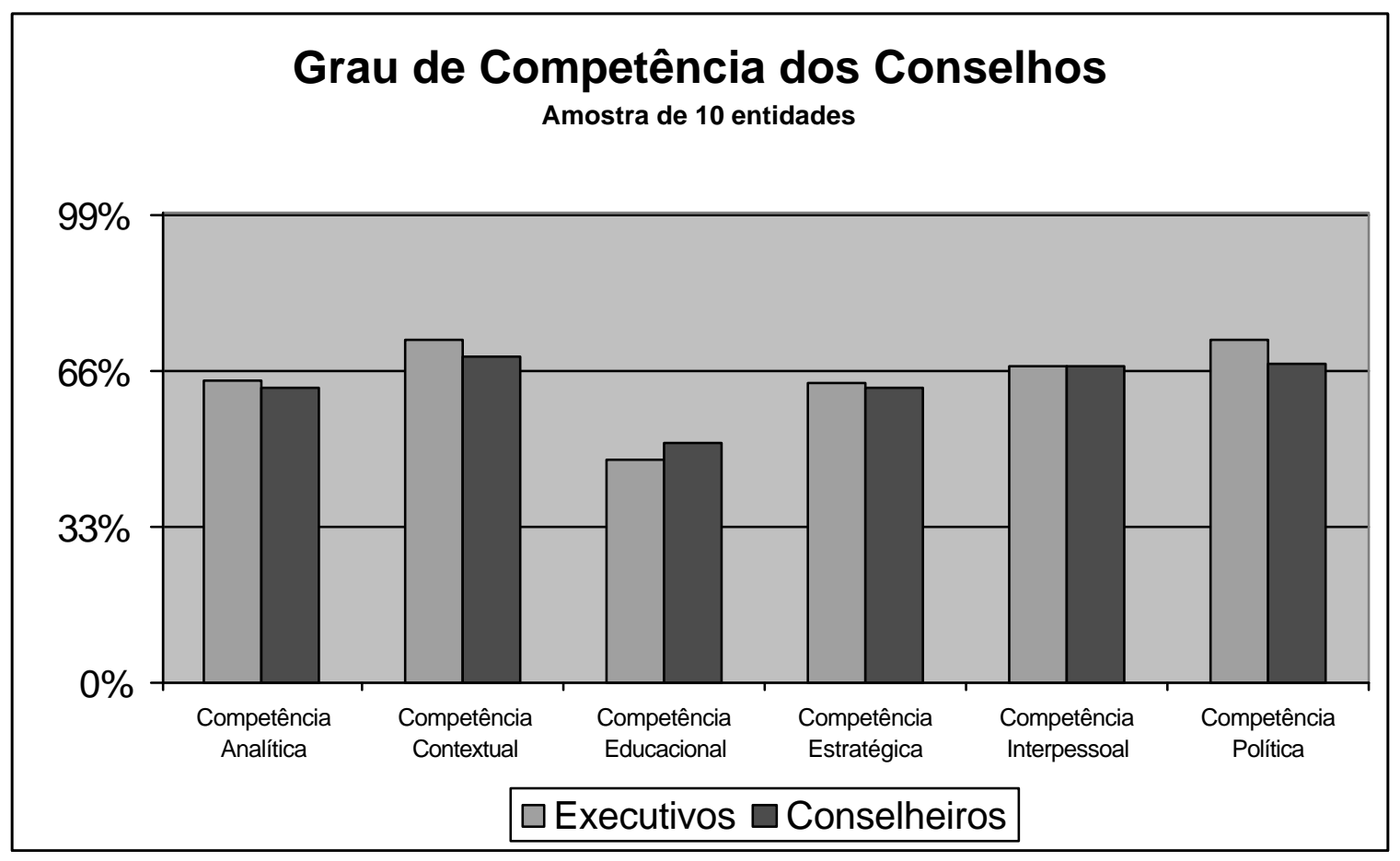

Para avaliar a adoção de práticas específicas de atuação do conselho, a seguir é feita uma análise por competência das respostas dadas por todos entrevistados aos questionários. Procura-se, com o trabalho a seguir, identificar as práticas mais e menos comuns na operação dos conselhos das organizações da sociedade civil participantes desta pesquisa. Para fins de análise, são considerados os 3 itens mais e menos pontuados em cada competência. 


\subsubsection{COMPETÊNCIA ANALÍtICA}

$\mathrm{Na}$ avaliação da competência analítica dos conselhos, os itens que receberam as menores pontuações foram:

- Questão 9: "O Conselho levanta perguntas difíceis de serem respondidas, que exigem pensar muito" (47\% dos pontos);

- Questão 10: "O Conselho faz perguntas para relacionar os temas discutidos à organização toda e a um sistema maior" (50\%);

- Questão 6: "O Conselho faz perguntas e comentários como se fosse membro de diferentes audiências da organização" (52\%).

As afirmações que receberam as maiores pontuações foram:

- Questão 11: "O Conselho lista os riscos econômicos, financeiros e jurídicos que uma decisão importante pode trazer" (82\%);

- Questão 8: "Diferenças de opinião dentro do Conselho são resolvidas com informação e argumentos, não por voto" (77\%);

- Questão 12: "O Conselho lista os riscos políticos, humanos e sociais que uma decisão importante pode trazer" (75\%).

Estes dados sugerem que a maioria dos conselhos participantes desta pesquisa trabalham pouco com perguntas e se ocupam bastante com riscos. No processo de análise dos problemas e situações das suas organizações parece que estes conselhos mais freqüentemente opinam sobre os riscos de determinadas decisões - e as diferenças de opinião, quando existem, são resolvidas pelo diálogo e pela ponderação, segundo os entrevistados.

Pelo nível de pontuação alcançado (82\%), a dimensão econômica e financeira é bastante considerada pelos conselhos. Juntando estas informações, fica a dúvida se realmente os conselhos destas organizações têm dedicado parte do seu tempo para examinar os assuntos institucionais sob diferentes pontos de vista - a impressão é que os conselheiros tendem a confiar mais em julgamentos baseados na própria experiência, o que, entretanto, carece de um estudo mais aprofundado para ser confirmado. Sobre isso, Chait et allii comentam:

\section{Múltiplas perspectivas capacitam as pessoas a se tornarem melhores gestores e líderes ... líderes com a capacidade de usar múltiplas lentes tendem a ser mais eficazes do que aqueles que analisam e agem sobre todos os problemas usando uma única perspectiva.}

Fica a dúvida também a respeito da complexidade das questões que são trazidas a estes conselhos questões complexas e interrelacionadas exigem análises mais cuidadosas, para as quais a capacidade de fazer perguntas é fundamental. 


\subsubsection{COMPETÊNCIA CONTEXTUAL}

Quanto à competência contextual, considerada aquela em que os conselhos desta pesquisa são mais desenvolvidos, as seguintes práticas foram consideradas mais freqüentes, de acordo com as respostas dadas aos questionários:

- Questão 21: "As questões ap resentadas ao Conselho são colocadas explicitando as ligações com a estratégia da entidade" (83\%);

- Questão 13: "Novos conselheiros recebem uma explicação detalhada da missão e das tradições da organização" (80\%);

- Questão 14: "Membros do Conselho falam para novos conselheiros sobre a cultura e a filosofia da organização" (75\%).

As práticas menos freqüentes dentro da dimensão contextual foram:

- Questão 18: "O Conselho faz reuniões específicas para revisar e nutrir a missão, os valores e a filosofia da entidade" (53\%);

- Questão 22: "O Conselho pergunta o que o comportamento das pessoas transmite da filosofia/prioridades da entidade" (62\%);

- Questão 24: "O Conselho pede informações sobre o perfil da equipe e o ambiente interno antes de tomar decisões" (67\%).

Uma primeira inferência que se pode fazer destes resultados é que provavelmente o processo de transmissão dos valores, tradições e princípios das entidades acontece mais informalmente do que formalmente. Não se adotam, aparentemente, reuniões formais somente para discutir a missão e os valores institucionais - a maioria dos conselheiros ficará sabendo, pelo contato com um outro, o que é importante e valioso para aquela instituição. Além disso, parece ser uma prática a apresentação de informações presentes da organização para os conselhos e sua comparação com algum tipo de plano institucional.

Estas respostas, entretanto, não dão indícios de que existe uma preocupação em renovar ou atualizar a cultura das instituições - a preocupação implícita nestes dados talvez seja maior com a transmissão da identidade institucional do que com o seu fortalecimento.

Nós não estamos sugerindo que os conselheiros devem submeter-se ou aceitar categoricamente todos os elementos desta cultura. Ao invés disso, acreditamos que os melhores conselhos eram capazes de cumprir bem o seu papel porque foram geralmente simpatizantes dos preceitos do contexto institucional, mais conscientes das expectativas e restrições que suas normas criam e mais sintonizados com as conseqüências das violações destes pontos básicos. Numa palavra, então, estes conselhos entendiam os ingredientes de um comportamento "adequado" e por isso estavam melhor preparados para decidir quando e onde agir diferentemente. 


\subsubsection{COMPETÊNCIA EDUCACIONAL}

As respostas relativas à competência educacional são menos pontuadas do que as demais competências. Entretanto, destacam-se como pontos mais freqüentes:

- Questão 27: "O Conselho reserva tempo para conselheiros fazerem exposições sobre temas específicos" (72\%);

- Questão 25: "Uma ata detalhada das reuniões é enviada a todos os conselheiros” (67\%);

- Questão 30: "O Conselho sugere nomes de conselheiros para auxiliar em atividades específicas na instituição" (65\%).

As práticas consideradas menos freqüentes no trabalho dos conselhos foram:

- Questão 33: "Cada conselheiro recebe comentários sobre seu desempenho como membro do Conselho" (22\%);

- Questão 29: "O Conselho faz reuniões para avaliar o desempenho e a eficácia do trabalho do Conselho" $(37 \%)$;

- Questão 26: "O Conselho fornece e atualiza uma pasta para cada conselheiro com informações sobre a organização" (40\%);

- Questão 32: "O Conselho pede para pessoas da organização e de fora dizerem como avaliam o trabalho do Conselho" (40\%);

- Questão 34: "O Conselho promove palestras, visitas e cursos para educação e capacitação dos conselheiros" (40\%).

Os conselhos das entidades paulistas pesquisadas aparentemente preocupam-se em manterem-se informados sobre o que acontece em suas reuniões, através de atas, bem como sobre temas específicos dominados por membros do grupo. Parece existir, ainda, um esforço freqüente para envolver outros conselheiros nas atividades das instituições.

Entretanto, denota-se que o desenvolvimento destes conselhos está muito dependente das avaliações de suas reuniões (65\%). Esta é a única atividade de avaliação que é adotada com alguma freqüência - não existe, pelo que estes dados estão mostrando, uma preocupação significativa e sistemática com o desempenho do conselho. $\mathrm{O}$ exame deste quadro levanta algumas questões:

- Será que existe uma cultura de que o esforço voluntário não deve ser avaliado ou criticado?

- Existe um receio "no ar" de que qualquer comentário nessa direção possa ser mais prejudicial do que contributivo?

- Os conselhos são vistos como grupos que não têm muito o que aprender e desenvolver-se?

- As lideranças dos conselhos sentem-se incapazes de criar uma cultura de aprendizagem e desempenho nestes grupos?

Como um tipo de grupo de trabalho, os conselhos também requerem uma base comum de conhecimento para funcionarem eficazmente. Em outras palavras, 
conselhos têm muito que aprender. ... Conselhos pouco eficazes tendiam a assumir que experiências anteriores (apesar de nem sempre relevantes) como universitários, como conselheiros ou como executivos dariam quase todo o conhecimento necessário para ser um conselheiro competente.

Finalmente, por estas informações pode -se inferir que os esforços "educacionais" estão mais voltados ao conteúdo das questões com que lida o conselho, do que ao seu processo de trabalho: "com quê" trabalham os conselhos ao invés de "como" eles operam - exposição de temas específicos, distribuição de atas e envolvimento em atividades específicas têm a ver com o "o quê", não com o "como". Chait et allii a respeito disso comentam:

Os melhores conselhos buscavam maneiras para aprender mais sobre o processo do conselho- a forma pela qual o conselho fazia o seu trabalho. ... um "fator chave" de conselhos eficazes era a presença de "um mecanismo ativo para o conselho revisar sua própria estrutura e processo" ... conselhos efetivos, muito mais do que conselhos fracos, utilizavam retiros e outros meios para estimular o auto-exame. ... os conselhos mais reflexivos foram também os mais eficazes.

\subsubsection{COMPETÊNCIA ESTRATÉGICA}

Segundo as respostas obtidas com os questionários, os conselhos participantes da amostra freqüentemente:

- "Propõem que ações sejam tomadas antes que a situação se torne urgente ou crítica" (Questão 44, $72 \%)$

- "Falam sobre sua visão de como estará a comunidade e o mundo daqui a alguns anos" (Questão 38, $70 \%)$

- Perguntam-se "porque determinada questão é importante para o futuro da organização e seu público" (Questão 43, 70\%).

Por outro lado, dão menos atenção a práticas do tipo:

- "Para deliberar sobre problemas atuais, o Conselho verifica o plano institucional” (Questão 45, 53\%);

- "O Conselho propõe alguns indicadores a serem monitorados sobre o desempenho da organização" (Questão 48, 53\%);

- " "O Conselho pede àliderança executiva que apresente questões para orientar a atenção do Conselho" (Questão 47, 55\%).

Conselhos eficazes alocavam sua atenção propositadamente e analisavam questões com uma consciência aguçada das relações entre elas e assuntos maiores da estratégia institucional. A perspectiva dos conselhos mais fortes era inclusiva e holística, ao passo que os conselhos mais fracos eram mais propensos a lidar com as questões de uma forma desconectada entre si e, às vezes, aleatória. 
Os conselhos envolvidos nesta pesquisa dedicam, aparentemente, uma parte importante do seu tempo para falar do futuro e mostram-se preocupados em evitar que suas entidades enfrentem situações críticas e envolvam -se em empreendimentos mal direcionados. Parece que faz parte das suas atividades falar sobre 0 futuro institucional, discutir sobre tendências importantes para a comunidade e relacionar ambos. Estes conselhos parecem bastante propensos a influenciar as decisões institucionais com suas visões e perspectivas, denotando uma característica bastante dinamizadora - essencial para qualquer empreendimento.

Os resultados acima podem estar indicando, entretanto, que tais conselhos dedicam pouco do seu tempo para ouvir, avaliar e monitorar o desempenho institucional em relação às estratégias previamente definidas. Dedicando menos esforços para revisar o plano institucional, construir indicadores do desempenho institucional e discutir questões propostas pela liderança executiva, estes conselhos podem estar exercendo um papel menos consolidador e integrador do que o necessário.

Conselhos eficazes eram tanto orientados para a ação e orientados ao futuro. Dito de outra forma, conselhos suficientemente perspicazes para antever tendências e trajetórias eram capazes de agir com a devida antecedência para enfrentar situações desfavoráveis.

Orientar-se para o futuro não significa, absolutamente, ignorar o passado - ao contrário, implica reconhecêlo e utilizá-lo como fonte de conhecimento para decisões posteriores. A adoção de instrumentos simples, como um plano institucional e indicadores de desempenho, pode ser útil na medida em que são vistos como elementos representativos do passado, oferecendo parâmetros para a definição de estratégias e passos futuros, bem como para a correta inter-relação das diferentes questões diante da instituição. Sua não adoção também pode denotar um processo intuitivo, pouco organizado ou não sistemático de pensar no futuro - que parece ser o caso dos conselhos participantes deste estudo.

\subsubsection{COMPETÊNCIA INTERPESSOAL}

As afirmativas que receberam a pontuação mais baixa dentro da competência interpessoal foram:

- Questão 54: "O Conselho estabelece metas e uma agenda de trabalho para si próprio, que vai além das reuniões" (35\%);

- Questão 55: "O Conselho faz reuniões específicas para tratar da sua renovação e do processo de recrutar novos membros" (50\%).

Por outro lado, aquelas que receberam maior pontuação nesta dimensão foram:

- Questão 51: "Os conselheiros expõem suas opiniões sobre temas importantes, mesmo que diferentes de seus colegas" (90\%);

- Questão 52: "Os conselheiros fazem perguntas para assegurar que entenderam a opinião dos outros" (85\%);

- Questão 50: "Os conselheiros conversam muito entre si, não somente com a liderança da reunião" (78\%). 
Este panorama sugere que estes conselhos têm um bom grau de maturidade para a discussão em grupos, sentindo -se à vontade para expressar sua opinião quando for o caso, cuidando para que todos consigam se entender e interagindo espontaneamente. Não parece haver nestes conselhos uma atmosfera opressiva; ao contrário, parece predominar um clima de respeito e cordialidade entre os conselheiros. Uma outra impressão importante que fica dos questionários é que a maioria dos conselheiros não são estranhos entre si, pois boa parte deles comunica-se entre si entre as reuniões $(72 \%)$.

Este panorama sugere, porém, que o clima de cordialidade existente pode estar beirando a informalidade excessiva em alguns casos, pois justamente as assertivas menos pontuadas referem-se a modos sistemáticos de trabalho - os extremos de pontuação obtidos nesta competência ( $90 \%$ e $35 \%$ ) reforçam essa impressão. Ou seja, aparentemente estes conselhos trabalham mais como grupos informais do que como equipes de trabalho, talvez por isso evitando assumir uma agenda formal e definir metas para si próprios. A não existência de uma cultura de avaliação e retroalimentação detectada na análise da competência educacional também reforça este ponto.

Equipes bem sucedidas ... são tipicamente motivadas e unidas ao redor de metas compartilhadas e realistas. Quando seus objetivos são atingidos ... o orgulho do grupo aumenta e se fortifica o senso de união. ... Típico de conselhos menos efetivos, ... conselheiros foram incapazes de identificar uma única meta para seu conselho... Conselhos inefectivos enfatizavam esforços individuais e acentuavam seus efeitos negativos na auto-imagem do grupo.

Diante dessa informalidade, também o desenvolvimento de novas lideranças e a renovação dos conselhos pode estar sendo subestimada por estes grupos, a princípio.

Conselhos inefectivos eram virtualmente indiferentes àquestão do desenvolvimento de novas lideranças e da sucessão ... Os efeitos de tal apatia eram tanto óbvios quanto substanciais. Sem um esforço contínuo e consciente para cultivar lideranças, os conselhos estavam a ponto de carecer de líderes, usualmente mais cedo do que tarde.

\subsubsection{Competência Política}

Quanto à competência política, os conselheiros e executivos entrevistados indicaram que nos seus conselhos os seguintes comportamentos são mais freqüentemente observáveis:

- "O Conselho reconhece explicitamente que a equipe executiva tem total autonomia sobre certas decisões" (Questão 61, 90\%);

- "Os conselheiros falam diretamente com pessoas da equipe executiva e técnica" (Questão 69, 87\%);

- "Quando há um problema interno delicado, conselheiros propõem-se a trocar idéias e pensar junto" (Questão 71, 87\%).

Por outro lado, é pouco comum encontrar conselhos adotando as práticas que seguem: 
- "Representantes das audiências da organização são convidados a participar de reuniões do Conselho" (Questão 62, 48\%);

- "O Conselho consulta diferentes públicos da instituição para deliberar sobre questões que podem afetá los" (Questão 67, 55\%);

- "O Conselho sugere nomes de parceiros para participar do planejamento da organização" (Questão 64, $60 \%)$

- "O Conselho pergunta como está o relacionamento da equipe executiva com os diferentes parceiros" (Questão 68,60\%).

Os indicativos de tais resultados são evidentes: os conselhos destas organizações paulistas reconhecem a importância e o papel das equipes executiva e técnica na governança institucional, mas fazem muito pouco para incluir audiências externas neste processo. Ou seja, estes conselhos aparentemente ocupam-se com as relações com as equipes institucionais, dedicando-se a consultá-las, a interagir com elas e a ajudálas na solução de determinados problemas. Ao contrário, pouca é a ocupação com audiências externas à instituição, sejam parceiros ou clientes - o que pode refletir um certo "fechamento" destas instituições ou uma visão mais restrita, organizacional, do processo de governança, não reconhecendo a validade da sua participação nos processos de decisão. Também pode refletir a existência de um certo distanciamento ou isolamento do conselho em relação aos públicos externos das entidades que governam.

Apenas membros de conselhos ineficazes pareciam ser cegos para a sua responsabilidade quanto ao fortalecimento das relações com os constituintes organizacionais. ... Em comparação, membros de conselhos mais eficazes expressaram um forte senso de dever que o conselho tinha que ajudar a desenvolver e manter relacionamentos construtivos com e entre os vários constituintes (da entidade).

Neste contexto, parece que o principal mecanismo de comunicação com o público-alvo adotado por estes conselhos é a interação com a equipe institucional, predominantemente, portanto, indireta.

A maioria dos conselheiros dos conselhos mais fracos (e alguns médios) eram extremamente relutantes em ter comunicação direta com vários constituintes...

\subsection{DeSEMPENHO ESPECÍfICO dOS CONSELHOS - ANÁLISE dOS DEPOIMENTOS}

As informações e análises realizadas anteriormente dão uma idéia relativamente objetiva de como operam os conselhos das 10 organizações da sociedade civil participantes desta pesquisa. Visando aprofundar esta descrição e ao mesmo tempo avaliar a validade destas práticas no contexto de cada uma das organizações, efetua-se a seguir um estudo dos depoimentos obtidos com os entrevistados. 


\subsubsection{ENTIDADE 4}

\subsubsection{Contexto institucional}

A Entidade 4 é a única das organizações participantes da pesquisa que tem a forma jurídica de uma cooperativa. Atende crianças e adolescentes de 7 a 18 anos (gratuitamente para os pais), filhos de famílias de baixa renda da Zona Sul de São Paulo, matriculados na rede pública de ensino; oferece atividades e oficinas diversificadas, além de assistência médica e odontológica, desenvolvendo uma formação pessoal, social e profissional. Foi constituída em 1994, tendo como objeto a criação e manutenção de uma estrutura de bens, pessoas e serviços, que dê suporte ao cooperado para a prática de atividades de assistência social, benemerência e filantropia. A finalidade é diminuir o risco social enfrentado pelo jovem carente no contato cotidiano com a marginalidade.

Segundo o estatuto, a Entidade 4 é administrada por um conselho de administração composto por 5 membros, todos cooperados. Os mandatos dos membros do consel ho têm a duração de 3 anos, sendo obrigatória, pelo estatuto, a renovação de pelo menos 2/5 dos conselheiros, eleitos em assembléia geral. Compete ao conselho de administração planejar e traçar normas para o funcionamento, as atividades e serviços da cooperativa, cabendo-lhe, entre outras, as seguintes atribuições:

- Fixar a jornada de trabalho dos membros que ocupam cargos executivos;

- Zelar pelo fiel cumprimento do objeto da cooperativa;

- Programar os investimentos;

- Providenciar os recursos financeiros para as operações e serviços;

- Fazer o orçamento anual;

- Estabelecer normas de controle das operações e dos serviços;

- Fixar normas para a administração dos recursos humanos;

- Deliberar sobre a contratação e demissão de seus auxiliares diretos;

- Fixar o limite máximo do saldo que poderá ser mantido em caixa;

- Movimentar os fundos da entidade;

- Contratar serviços de auditoria e consultoria;

- Zelar pelo cumprimento das leis do cooperativismo;

- Acompanhar todas as atividades da cooperativa nas áreas pedagógica, administrativa e financeira.

Ainda de acordo com o estatuto, "os componentes do Conselho de Administração, bem como os liqüidantes, equiparam-se aos administradores das sociedades anônimas para efeito de responsabilidade criminal". Existem ainda um conselho fiscal e um conselho consultivo, praticamente inoperantes - na prática a entidade é dirigida pelo conselho de administração (que a fundadora chama de diretoria) e por um grupo de gerentes. 
As duas lideranças entrevistadas se conhecem há mais de 20 anos; a executiva é gerente administrativa financeira e a conselheira entrevistada é sua principal fundadora, exercendo uma influência visionária e carismática para com as pessoas ao seu redor.

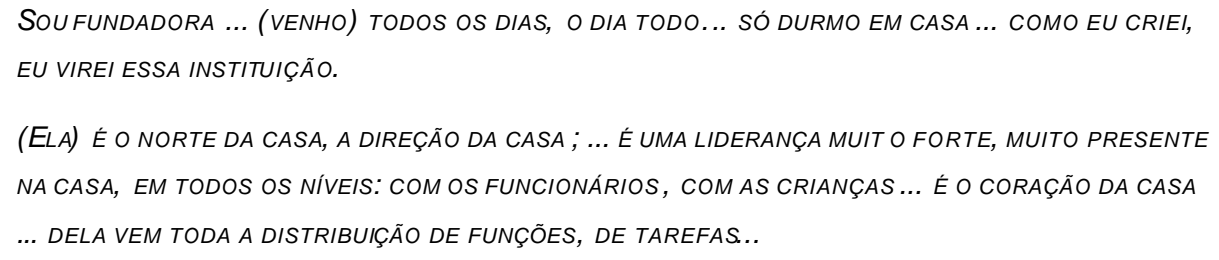

Funcionalmente, além do conselho de administração há uma gerência executiva, remunerada, composta por 4 pessoas, responsáveis pela administração da entidade no diaa-dia. Não há, aparentemente, uma diferenciação formal entre conselho e diretoria, a ponto da presidente chamar o conselho de administração de diretoria.

TEM A DIRETORIA, NO PAPEL DO ESTATUTO, AÍ TEM AS GERÊNCIAS ... AÍ JÁ NÃO É PAPEL DO ESTATUTO ... A DIRETORIA AQUI DENTRO É EFETIVA, NÃO É SÓ DE ESTATUTO, NÃO ...

Segundo a executiva, as pessoas que fazem parte do conselho:

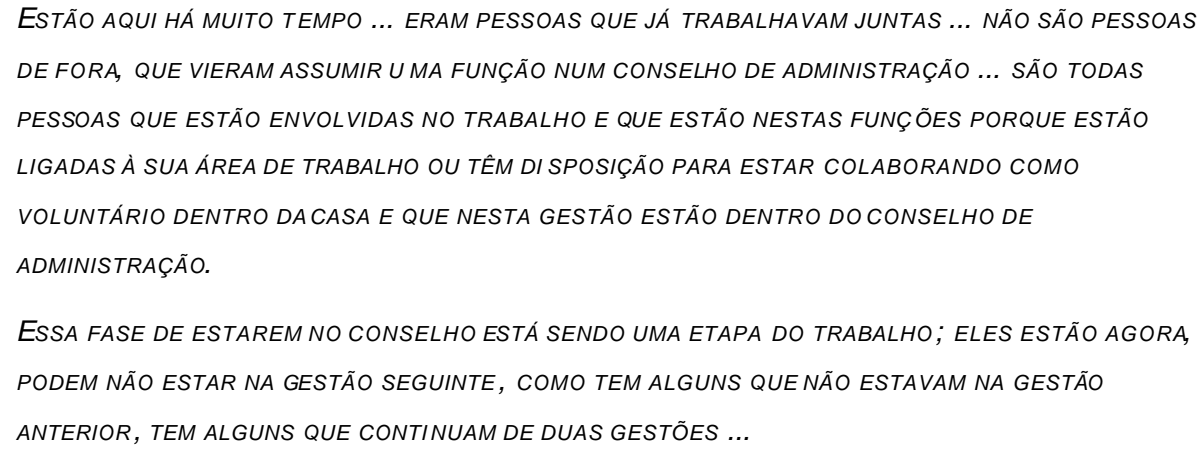

O contexto descrito acima mostra uma organização em que os vínculos entre as pessoas são antigos e fortes, havendo uma identificação muito intensa com a instituição. Por exemplo, diz a executiva:

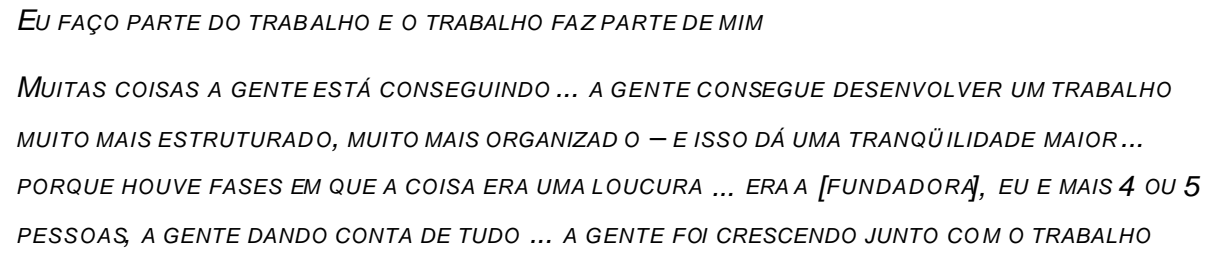

\subsubsection{O Papel do Conselho nos Incidentes Críticos}

Os principais incidentes críticos descritos pelas entrevistadas da Entidade 4 disseram respeito:

- À aceitação ou não de uma criança com um perfil diferente do usual (em regime de liberdade assistida, tendo um significativo contato anterior com traficantes de drogas). Neste caso, o conselho teve um papel decisório-aprovador, solicitando informações detalhadas, compondo uma junta e acatando a sugestão da fundadora. 
Houve no ConselHo: VAMOS ACEITAR, NÃO VAMOS? ... TINHA PEDIDO DA PROM OTORA ... EU CONVERSEI COM A MÃE, COM O PADRASTO, FIZEMOS UMA JUNTA... EU FALEI. VAMOS TOPAR ESSE DESAFIO ... PORQUE FOI A PRIMEIRA NA [ENTIDADE 4] COM ESSA FICHA.

DEU CERTO, HOJE ... ESTÁ COM 13 ANOS, LINDA, MUDOU TOTALMENTE... ERA UM DESAFIO ENORME ... TODO MUNDO, ATÉ O VICE-PRESIDENTE, SABE QUEM É ... E TORCE E VIBRA POR ELA.

- À busca pelo pai de uma criança, para autorizá-la a viajar para o exterior. Uma conselheira em especial participou do caso, disponibilizando contatos pessoais que permitiram o acesso da entidade às informações necessárias.

[Conselheira] ... localizou o pal ... POR ela ser diREtora do Carandiru ... ela val com os MEIOS LEGAIS MAIS RÁPIDOS ... ISSO AÍ EU NÃO TENHO ACESSO.

- A um incêndio numa obra institucional, provocado por pessoas externas à entidade insatisfeitas com a decisão de constrúlta fora do seu bairro. Nessa situação emergencial, o conselho atribuiu tarefas específicas a cada um dos conselheiros, conforme sua capacidade pes soal - alguns foram captar recursos, outros ajudaram na preparação de doces para a festa de inauguração.

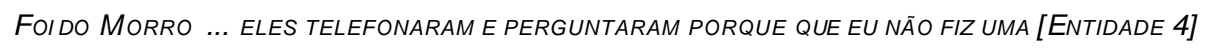

"AQUI" ... ESTAVAM TERMINANDO A OBRA E ELES JOGARAM FOGO.

- Ao apoio a uma menina que se machucou acidentalmente e não podia contar com um suporte adequado da família. Dois conselheiros mobilizaram médicos de sua confiança para atendê-la e ficaram com a menina em suas casas até que ela estivesse recuperada.

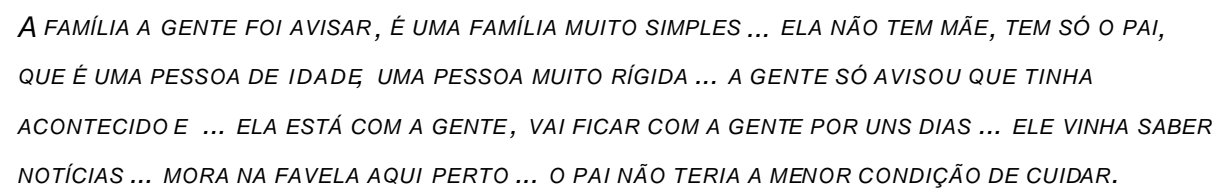

- A uma intimação para pagamento de uma elevada multa ao Imposto de Renda. Um conselheiro mais ligado à área contábil solicitou apoio de um escritório especializado e descobriu que o contador havia cometido um equívoco, providenciando a devida orientação para que isso não voltasse a acontecer.

FOI UM CHOQUE PARA A GENTE ISSO ... FOI NUMA FASE EM QUE A GENTE ESTAVA TERMINANDO A CONSTRUÇÃO E PRECISAVA DE MUITOS RECURSOS PARA PODER TERMINAR... JAMAIS PARA UM IMPOSTO DE RENDA QUENÃO ERA DEVIDO.

- À busca de aprovação, junto ao CNAS, de um estatuto completamente diferente dos usuais. Neste caso o conselho como um todo trabalhou vários dias na elaboração de uma justificativa convincente para o órgão governamental.

FOI O MOMENTO EM QUE O CONSELHO DE ADMINISTRAÇÃO SE JUNTOU PARA ELABORAR UMA JUSTIFICATIVA DO PORQUÊ NÃO ACEITAR AQUELE PARECER NEGATIVO, DE FUNDAMENTAR TODA A CONTRAPOSIÇÃO.

As descrições destes incidentes revelam um conselho que atua de diferentes maneiras, conforme a situação exige, exercendo desde um papel de captador de recursos até um papel de suporte e orientação àliderança executiva, mostrando flexibilidade e proximidade da instituição. Nestes casos, o trabalho do conselho se deu tanto como grupo e através de determinados conselheiros, individualmente. Para as decisões com caráter 
mais simbólico e estratégico, parece que o grupo é mobilizado. Para as tarefas de suporte e com um caráter técnico e contingencial mais específico, utilizaram-se determinadas qualidades de um ou mais membros do grupo.

Para as entrevistadas, os principais fatores responsáveis pelo desempenho, considerado bom, deste conselho são:

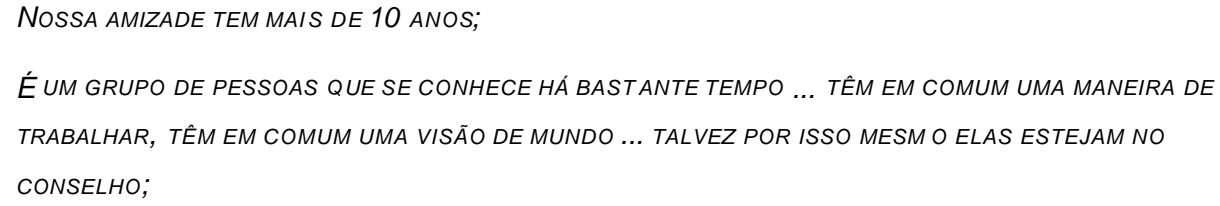

A Entidade 4 tem alguns valores para a atuação dos seus grupos diretivos, que também podem ser considerados fatores relevantes para o desempenho do conselho. Os principais valores, enunciados nas entrevistas, são:

A DIRETORIA AQUI DENTRO É EFETIVA, NÃO É SÓ DE ESTATUTO, NÃO ... O QUE EU ESCREVI NO ESTATUTO EU FAÇO;

PASSOU DO PORTÃO, ENTROU AQUI DENTRO, É EDUCADOR!

TANTO OS FUNCIONÁRIOS QUANTO OS MENINOS SÃO PARCEIROS;

QUALQUER UM AQUI DENTRO TEM QUE SABER O NOME DAS CRIANÇAS;

A DIRETORIA TEM QUE SABER TODOS OS PROBLEMAS, NÃO É SÓ QUESTÃO FINANCEIRA;

A GENTE TEM QUE SE FAZER RECONHECER DA MANEIRA QUE A GENTE QUER;

COMO A GENTE TEM MUITA CONVERSA, NÃO FICA ESPERANDO MARCAR DATA;

PARA A DIRETORIA SÓ VAI QUEM CONHECE A[ENTIDADE 4];

QUEM NÃO ESTÁ DISPOSTO A APRENDER NÃO PODE ENSINAR;

PARCEIRo, PARCERIA ... COOPERAR PARA COMPETR;

O MEMBRO DE UMA DIRETORIA TEM QUE SER PARCEIRO MESMO, NÃO BASTA SÓ SER DIRETOR, TEM QUE EXECUTAR A DIREÇ ÃO DE CORPO E ALMA;

NÃO HÁ NECESSIDADE DE FICAR 24 HORAS NUMA INSTITUIÇ ÃO, DESDE QUE HAJA SEMPRE ESSAS REUNIÕES A CADA QUINZE DIAS OU SEMANAL;

Finalmente, parece existir uma distinção clara entre o trabalho do conselho e o trabalho da gerência, evidenciada por comentários do tipo:

A GERÊNCIA É DIÁRIA ... ATUAÇÃO MAIS ATIVA NO SENTIDO DO DIA-A-DIA ... TEM QUE ESTAR AQUI TODOS OS DIAS, DE PREFERÊNCIA 18 HORAS POR DIA ... 


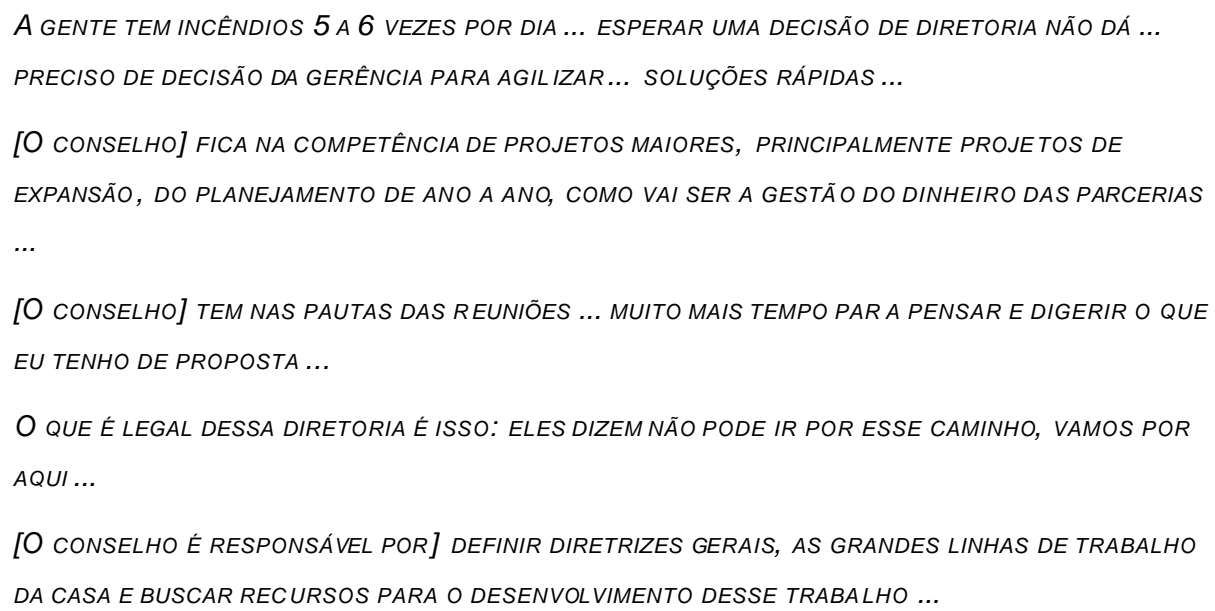

Quanto a resultados obtidos, pode-se dizer que o conselho da Entidade 4 foi efetivo nos casos apresentados porque:

- Resolveu pelo menos um problema definitivamente, impedindo que se repetisse;

- Ajudou a solucionar casos agudos;

- Preservou a identidade organizacional;

- Assegurou recursos para a entidade (com a isenção fiscal).

Em síntese, a Entidade 4 parece ser governada por um grupo de pessoas, liderado por uma de suas fundadoras, cuja representação maior acontece no conselho de administração. Existe aparentemente um bom nível de definição de funções e um alto grau de comprometimento com a causa - o conselho é bem diferenciado da gerência. As pessoas neste grupo têm um vínculo pessoal estreito entre si, conhecendo-se bem. Os membros do conselho de administração têm uma presença regular na entidade, contribuindo em diversas situações específicas e oferecendo considerável suporte àliderança executiva - exercem um papel de guardiões tanto da viabilidade, quanto da identidade institucional.

\subsubsection{Competências desenvolvidas}

A partir da análise dos incidentes críticos citados, podese avaliar quais são as competências predominantes e a desenvolver na equipe que governa a Entidade 4.

Dimensão analítica: embora as gerências estejam preparadas para soluções rápidas, os conselheiros têm um cuidado mínimo de informar-se adequadamente para tomar decisões - o caso do fiscal do IR e o caso da menina de 13 anos demonstram isso. Pelos comentários da conselheira - de que acontecem "altos paus" nas reuniões - provavelmente os conselheiros sentem-se livres para levantar dúvidas e à vontade para discutir diferenças de opinião.

No caso do conselho da Entidade 4, confirma-se a tendência de adoção de processos decisórios baseados em argumentos, não em votos, mas com grande influência da sua fundadora. Ainda, fica aparente o pouco uso de perguntas nos processos de análise de problemas. Quanto à natureza das questões trazidas ao conselho, percebe-se um grau diversificado de complexidade - foram trazidas questões ligadas à identidade 
institucional, mas existe uma tendência de mobilizar o conselho para questões pontuais, relativas ao presente e emergenciais.

Dimensão contextual: é um dos pontos fortes desse grupo dirigente, graças àpresença dos fundadores. Os conselheiros parecem conhecer muito bem a história e as tradições da organização e reforçam, na solução de problemas, os valores institucionais. Nos exemplos acima, várias vezes a conselheira citou princípios de trabalho e contou casos práticos que os simbolizavam.

Esta Entidade confirma a impressão deixada pelos questionários de que a transmissão da identidade institucional ocorre de maneira predominantemente informal e direta, de pessoa a pessoa. Não existem, pelos relatos obtidos, reuniões ou retiros formais de planejamento, imperando, ao contrário, um contato muito intenso da liderança fundadora com cada um dos membros do conselho.

Dimensão educacional: a presidente do conselho tem, com as gerentes, participado de atividades educacionais: cursos e consultorias. É o principal indicador de que o conselho está pelo menos atento a esta necessidade. Além disso, parece que existe uma cultura de abertura à aprendizagem, expressa pela fundadora da seguinte forma:

QUEM NÃO ESTÁ DISPOSTO A APRENDER NÃO PODE ENSINAR...

Apesar dessa premissa, formal e sistematicamente pouco ocorre na Entidade 4 para a formação dos conselheiros, havendo grande dependência ainda da atuação da liderança fundadora. Por outro lado, o fluxo de informações entre os conselheiros e a liderança executiva é baseado em conversas pessoais e reuniões freqüentes, bem como pela presença regular de conselheiros na entidade.

Dimensão estratégica: o papel visionário da presidente parece ser a principal fonte de um bom grau de competência nesta dimensão. Possivelmente existe a preocupação em "afinar" prioridades estratégicas e dirigir atenção a questões de magnitude estratégica, como se pode perceber pelo seguinte comentário:

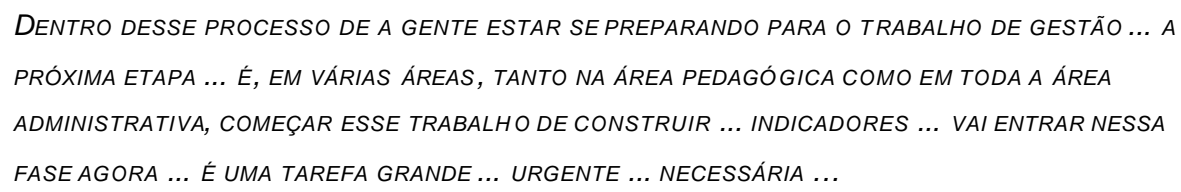

A atuação nos casos do fiscal do IR e do registro no CNAS refletem a preocupação em evitar que problemas voltem a acontecer. Não houve, entretanto, qualquer menção a um plano institucional, confirmando nesta entidade uma tendência revelada nos questionários de que o futuro é discutido de modo pouco sistemático. As reuniões normais entre a liderança executiva e o conselho parecem ser os fóruns em que o diálogo a respeito do futuro da entidade acontecem.

Por último, a maioria dos casos descritos representa questões relativas ao presente, o que indica ser este o foco principal do conselho.

Dimensão interpessoal: é um grupo antigo, que participou ativamente da construção da entidade, unido por vínculos ideológicos e de amizade, que trabalha em conjunto e bastante franco. Há, assim, uma comunhão de objetivos significativa e o princípio de "todos sabem de todos os problemas" denota um senso positivo de inclusão. A descrição dos papéis das gerentes e dos "diretores" feita pela conselheira indica que o grupo estabelece para si algumas metas (fazer o estatuto, construir uma fábrica, levantar fundos). A presença de 
uma liderança tão forte como a fundadora, porém, levanta a pergunta sobre como esse grupo identifica e cultiva novas lideranças - não há nenhuma menção significativa a esse respeito, exceto aquelas que revelam um desejo muito grande de permanecer:

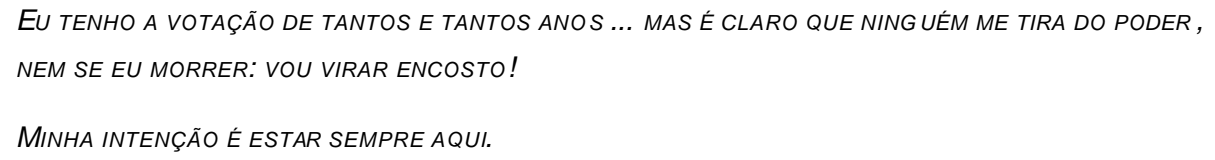

Este caso, confirma, conseqüentemente, algumas das impressões deixadas pelo questionário: de que os conselheiros não são estranhos entre si, que existe um clima favorável às discussões durante as reuniões e de que há um grau alto de informalidade nesta fase da entidade.

Dimensão política: ao tratar os adolescentes e funcionários como parceiros, o conselho está considerando sua responsabilidade por manter e nutrir as relações com algumas das principais audiências da organização. E, pela regularidade da presença, percebe-se que existe uma comunicação direta dos conselheiros com estas audiências. Os diferentes papéis são respeitados: da liderança fundadora, das gerentes, dos adolescentes. Pela postura adotada em diferentes casos, evita-se situações ganhaperde, como no caso do incêndio (não houve confronto) e no caso do CNAS (não houve batalhas jurídicas, mas um esforço em deixar claros os interesses primários).

Conforme detectado pelos questionários, entretanto, os casos descritos da Entidade 4 sugerem que os conselheiros ocupam-se mais das audiências internas à instituição, incluindo os adolescentes. Como não houve citações de envolvimento de pessoas de fora da entidade nas reuniões e trabalhos do conselho, esta impressão fica reforçada. O caso do incêndio, apesar da sua pouca profundidade, poderia ter sido explorado melhor pelo conselho, de diversas maneiras, caso este tivesse uma preocupação de representar e prestar contas æ̀s audiências externas da entidade.

\subsubsection{ENTIDADE 1}

\subsubsection{Contexto institucional}

A Entidade 1 foi fundada em 1986 e tem "como objetivo central a garantia de acesso à educação de qualidade para as crianças de baixa renda". Os objetivos sociais, segundo seu estatuto, são:

- Prestar assistência social a crianças e jovens carentes junto a locais comunitários e promover atividades educacionais;

- Promover e ou manter quaisquer atividades culturais, sociais, assistenciais e de prestação de serviços a terceiros;

- Se preocupar com a Promoção Humana e social em todas as suas atividades.

TEMOS 8 CRECHES COMUNITÁRIAS, 1 CJ ... BABY SITTER

Proposta pedagógica ... Amplar o horizonte cultural ... FormaÇão PeRMANENTE ... Áreas DE CONHECIMENTO ...

MontAMOS um DEPARTAMENTO PEDAGÓGICO ... CURSOS, ACOMPANHAMENTO 
Tanto a conselheira (presidente), quanto a executiva se consideram fundadoras da organização, com a qual têm uma identificação muito forte, apesar de terem vínculos formais diferentes:

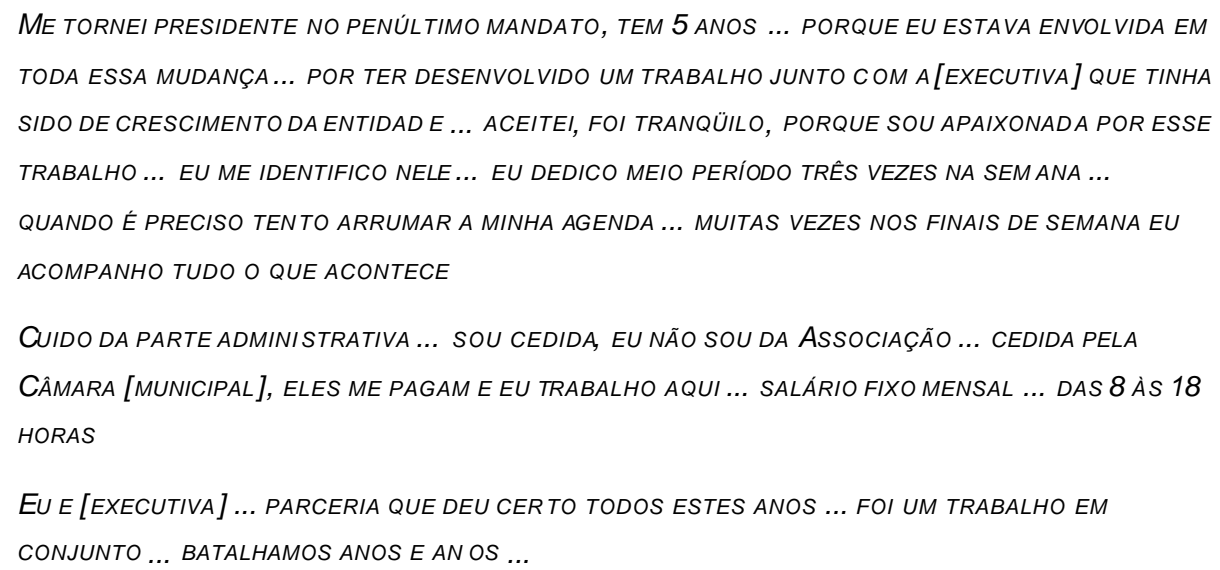

Segundo o estatuto, a Entidade 1 é administrada por uma assembléia geral, um conselho de administração, um conselho fiscal e um conselho consultivo. O conselho de administração é constituído por associados (teoricamente há mais de 24 meses) e existe para:

- Programar e elaborar o programa anual de atividades e executá-lo,

- Elaborar e apresentar o relatório anual,

- Entrosar-se com instituições públicas e privadas para mútua colaboração em atividades de interesse comum,

- Contratar e definir funcionários,

- Dar publicidade ao relatório de atividades e demonstrações financeiras, colocando-os à disposição de qualquer cidadão.

Ao conselho consultivo compete "opinar sobre os planos de trabalho e atividades da entidade, devendo elaborar estudos e sugestões sobre os mesmos"; este conselho foi criado recentemente.

Na prática, segundo as entrevistadas, a organização funcional é a seguinte:

Conselho de administração ... SÃo 8 ... MANDATO É de 3 ANOS, PODENDO SE PRORROGAR POR MAIS TRÊS... REUNIÕES MARÇO, JUNHO OU JULHO E NOVEMBRO ... HOUVE MUITAS REUNIÕES EM MARÇO ... FICOU TODO MUNDO MEIO ENJOADO

TEM ESSA ADMINISTRAÇÃO ... ESTÁ VINCULADA À IMPLEMENTAÇÃO DE NOVOS PROJETOS, O PESSOAL E A TESOURARIA ...

TEM UM DEPARTAMENTO QUE SERIA ADIREÇÃO PEDAGÓGICA DOS TRABALHOS ... A FORMAÇÃO CONTÍNUA DOS EDUCADORES, FORMAÇÃO DOS EDUCADORES NOVOS, SUPERVISÃO DA PROPOSTA PEDAGÓGICA E ATÉ ... ABASTECIMENTO DE MATERIAL DIDÁTICO E BRINQUEDOS ...

DEPOIS A GENTE TEM UM OUTRO QUE A GENTE CHAMA DE CAPTAÇÃo DE RECURSOS ... ELES FAZEM ABASTECIMENTO, BAZAR, CONTATO COM LUGARESE FAZEM AINDA PROJET OS, ESCREVEM OS PROJETOS

É TUDO UM POUCO NOVO ... A GENTE COMEÇOU A SE REORGANIZAR ASSIM A PARTIR DE MARÇO ... 
Tal como na Entidade 4, também aqui a liderança mais executiva faz uma confusão entre "diretoria" e conselho de administração, denotando um certo desconforto conceitual a respeito. A escolha pelo uso do verbete "conselho" foi motivado por questões legais:

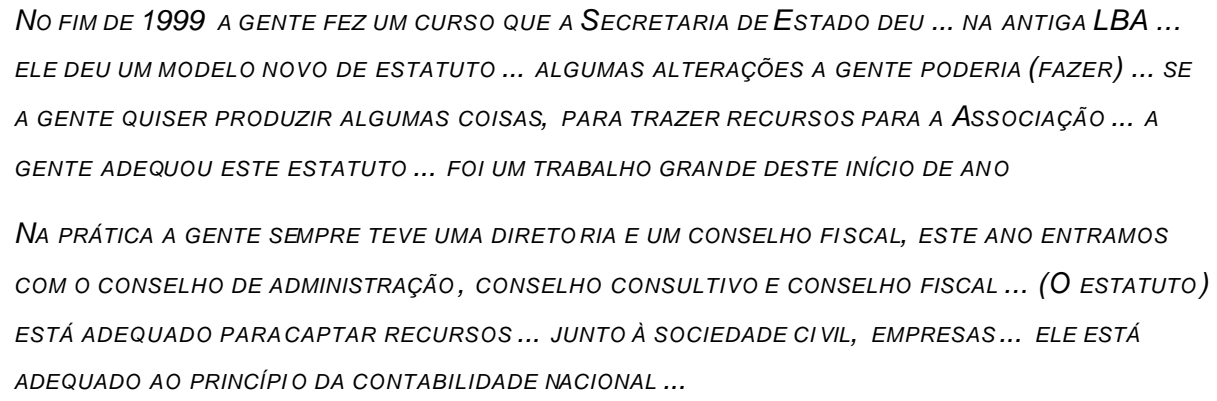

A executiva cuida mais dos negócios da administração da entidade e a presidente do conselho (conselheira entrevistada) acumula também a função de coordenadora pedagógica, para o quê está fazendo cursos de capacitação. As duas têm como fonte principal de satisfação os resultados e os propósitos da instituição:

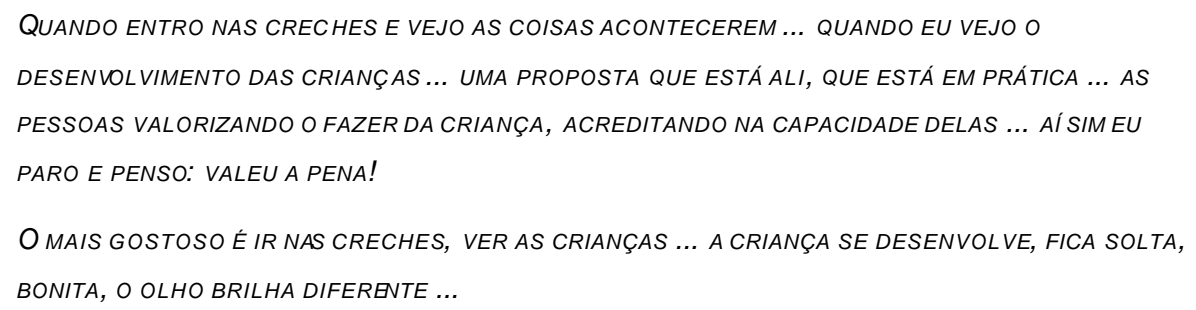

A Entidade 1 tem um caráter bastante popular, estando ativamente envolvida em movimentos comunitários, especialmente de mulheres e mães. Numa primeira fase institucional, muitas das pessoas que trabalhavam eram voluntárias da comunidade - aos poucos houve uma profissionalização e capacitação dessas pessoas, que adquiriram um novo "status":

A gente CHEgou a ter 200 domicílios COM CRIANÇAS ... PELA CIDADE TODA ... A GENTE AVALIOU QUE HAVIAM PROBLEMAS NESSA PROPOSTA, SE QUISESSE AVANÇAR PEDAGOGICAMENTE ... TINHA MUITA DIFICULDADE DEQUALIFICAR O TRABALHO ... ERA UM PROJETO MUITO BARATO ... AS MULHERES CUIDAVAM DA CRIANÇA E DA CASA DELAS ... POR UM GANHO MÍNIMO ... ERAM CASAS MUITO MODESTAS ... ESPAÇO FÍSICO FOI UMA QUESTÃO ... A EXPLORAÇÃO DA MULHER FOI OUTRA QUESTÃO ... POR OUTRO LADO, A DIFICULDADE DELA SE QUALIFICAR POR CONTA DE SER SOBRECARREGADA ... A GENTE FOI ABSORVENDO ESSES NÚCLEOS, QUE ERAM DOMICILIARES, EM NÚCLEOS COMUNITÁRIOS... A GENTE FOI ALUGANDO CASAS E LEVANDO ESSAS MÃES CRECHEIRAS PARA AS CASAS ... ERAM USADAS PELA ASSOCIAÇÃO ... ELAS FORAM SE TRANSFORMANDO LÁ DENTRO EM TRABALHADORAS MESMO, COM HORÁRIO, FUNÇÃO DEFINIDA ... FIZERAM TODAS TREINAMENTO... LEVOU CINCO ANOS ESSA MUDANÇA

EM 1994 NÓS CONSEGUIMOS ACABAR COM TODAS AS MÃES CRECHEIRAS ... AS CRECHES PASSARAMA SER CRECHES COMUNITÁRIAS E CONSEGUIMOS A FORMAÇÃO PEDAGÓGICA PARA TODAS AS PESSO AS QUE PARTICIPARAM DESTE TRABALHO ... A FORMAÇÃO MUDAVA A NOSSA CONCEPÇÃO DE VER ESSE TRABALHO DE CRECHE, ESSE TRABALHO ASSISTENCIAL ... GANHAVA UMA NOVA CARA ... QUE ERA ... CONSTRUTIVISTA, INTERACIONISTA ... ACREDITANDO NA CAPACIDADE DAS CRIANÇAS, ACREDITANDO NA FORMAÇÃO DOS NOSSOS PROFISSIONAIS, QUE NA ÉPOCA ERAM PESSOAS LEIGAS ... NÃO(SE) VIAM COMO EDUCADORAS ... 


\subsubsection{O Papel do Conselho nos Incidentes Críticos}

Foram 4 os incidentes narrados pelas entrevistadas, que diziam respeito a:

- Participação em um concurso para a construção de uma creche modelo e um centro de formação. O conselho participou da decisão de participar do concurso, envolveu-se na procura de terrenos, na preparação de documentos, na aprovação do projeto de construção, na negociação com parceiros, na definição de como seria o gerenciamento da nova unidade e de qual seria a unidade a ser desativada.

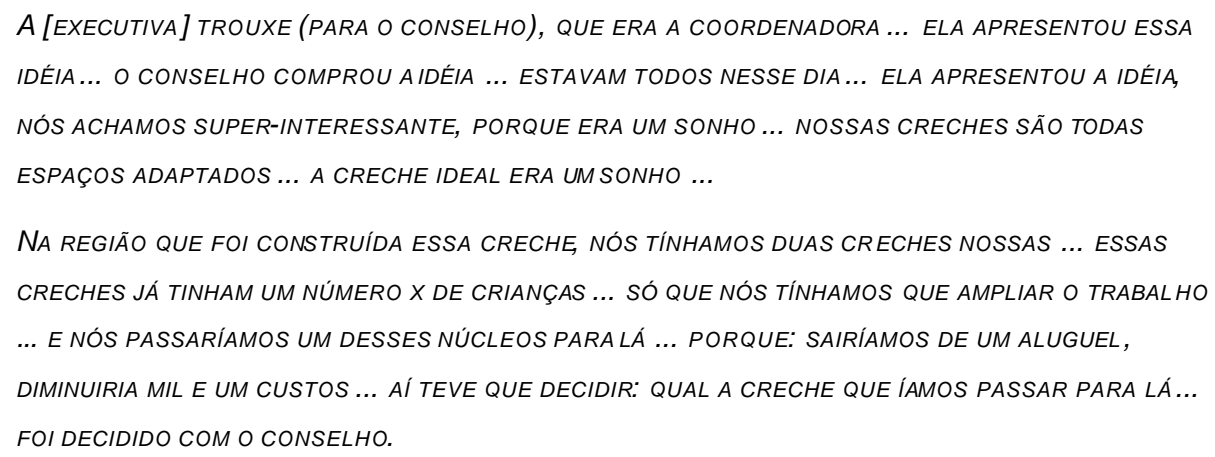

- Decisão de realizar atividades de formação das educadoras. Um conselheiro e a presidente do conselho tiveram a idéia e participaram da implementação de um passeio pedagógico com toda a equipe da entidade a cidades históricas brasileiras.

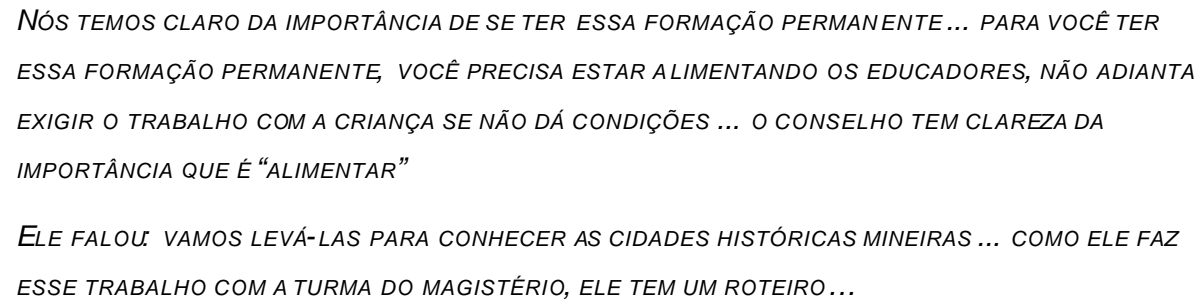

- Responder legalmente a um processo na justiça contra a entidade, devido a um acidente com uma das crianças. A presidente do conselho assumiu a representação da entidade no processo, participando de audiências e dando apoio às educadoras responsáveis.

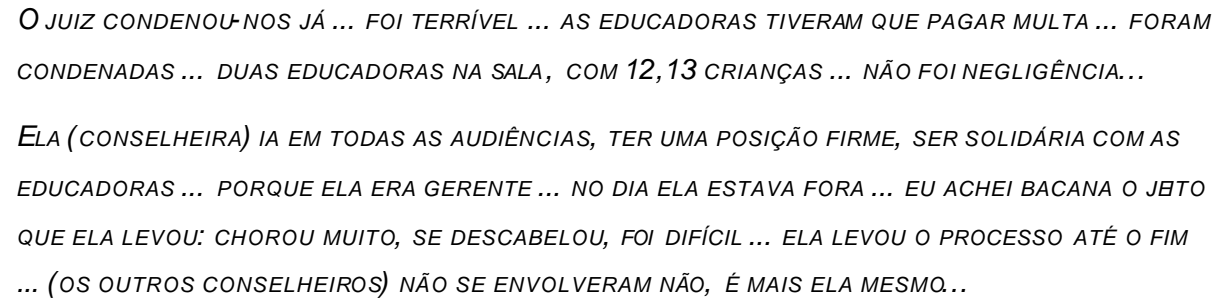

- Enfrentar dois meses sem recursos por causa de uma alteração nas leis fiscais do município. O conselho teve um papel de "gestor da crise", assumindo a responsabilidade por negociar dívidas e procurando evitar o desmantelamento da equipe.

A GENTE FOI FAZENDO DÍVIDAS, NEGOCIANDO DÍVIDAS, ATRASANDO PAGAMENTOS ATÉ TER DINHEIRO PARA PAGAR MESMO ... CONVERSÁVAMOS O TEMPO TODO ... A TESOUREIRA, [PRESIDENTE], ... FAZÍAMOS REUNIÃO COM TODAS ELAS ... TOMÁVAMOS DECISÕES EM CONJUNTO ... E O PESSOAL ATRASANDO PRESTAÇÃO, ATRASANDO ALUGUEL DECASA ... UMA SITUAÇÃO MUITO COMPLICADA ... 
CADA CRECHE ABRIU A SUA POUPANCINHA, POR CAUSA DESSE PERÍODO...

Estes incidentes mostram que o conselho nesta entidade ocupa-se com questões de governança institucional, tanto simbólicas, quanto funcionais. Em todos os casos descritos o conselho identificou riscos e oportunidades reais e potenciais para a proposta e a imagem da organização, seja no curto ou no longo prazo, e decidiutse por ações concretas ou atitudes simbólicas construtivas. Em dois dos casos a iniciativa foi de conselheiros individuais, em situações muito visíveis para o restante da entidade. Nos outros dois casos, absolutamente opostos (o sonho e a crise), o conselho agiu como grupo, sob a liderança da presidente e da executiva. Também nesta instituição soubese tirar proveito de qualidades individuais dos membros do conselho e do potencial da atuação deste grupo em particular. O conselho aparentemente tem nessa organização um papel simbólico significativo, sendo uma fonte de legitimidade para a liderança das fundadoras e de inspiração para as demais educadoras.

Os principais resultados da atuação deste conselho, identificados pelas entrevistadas, foram:

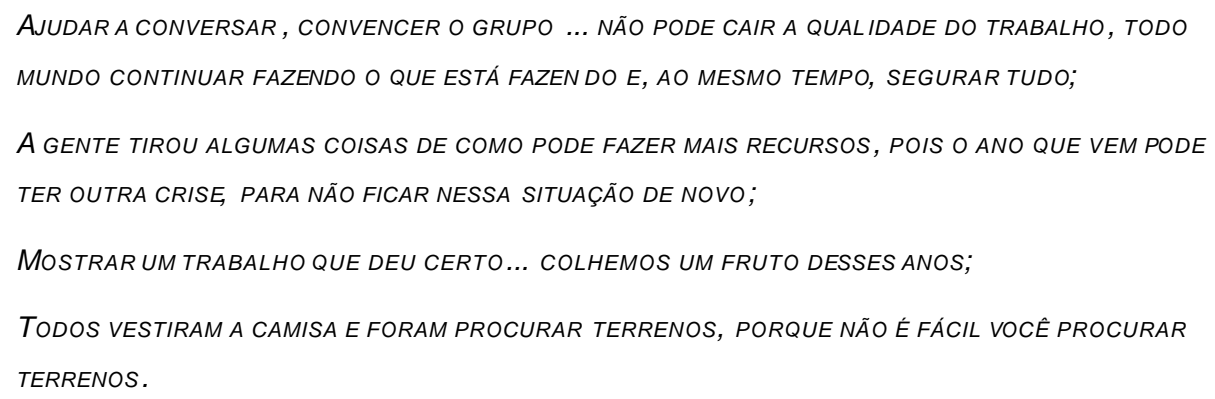

Este conselho tem um estilo bastante informal e operacional, envolvendo-se naturalmente em questões específicas da instituição e participando ativamente dos seus desafios. Tem atuado como apoio em momentos críticos e na execução de atividades específicas e pode ser considerado responsável pelo governo da instituição - especialmente porque tem sua liderança é exercida pelas fundadoras. Um aspecto específico destaca-se: a presidente tem uma forte influência na parte técnica da instituição.

Por ele ser muito operacional, ele É MENOS CONSULTIVO, EMBORA A GENTE CONSULTE TUdO O QUE VAI FAZER... EMBORA ÀS VEZES DE FORMA NÃO MUITO ORGANIZADA.

Porém, aparentemente está mais bem definido no papel do que na prática. É muito difícil, neste caso, visualizar o conselho œmo um órgão ou instância bem diferenciado. Na prática, as fundadoras exercem a liderança da organização, apoiadas pela equipe profissional e por alguns voluntários, que são ou conselheiros administrativos ou consultivos. Considerando que as duas fundadoras são atualmente conselheiras, a importância do conselho é fundamental. Dentro do conselho há pessoas com uma função mais executiva (presidente e administradora) e outras com uma função mais de apoio, porém há uma atuação forte do grupo, especialmente diante de decisões de alto risco e impacto institucional.

É UM LEQUE QUE SE ABRIU ... SÃO MAIS PESSOAS QUE TÊM UMA VISÃO DE EDUCAÇÃO CLARA E QUE TÊM OPINIÕES... SÃO MAIS PESSOAS PARA DAR SUGESTÕES, PARA DAR IDÉIAS ... NÃO É UMA, DUAS PESSOAS DISCUTINDO; É UM GRUPO DISCUTINDO, QUE TEM OS MESMOS IDEAIS.

Finalmente, nesta instituição existe uma parceria forte entre a liderança executiva e a presidente do conselho. 


\subsubsection{Competências desenvolvidas}

A competência analítica deste conselho advém da discussão conjunta dos problemas e do hábito de pedir opiniões de outras pessoas e buscar informações com lideranças externas. Este conselho discute suas questões e situações baseando-se em argumentos e procura, pelo menos intuitivamente, levantar diferentes perspectivas antes de decidir. Aparentemente, a diversidade da composição do conselho (há pedagogas, donas de casa, professor, advogada, empresário) contribui para que naturalmente surja uma razoável variedade de pontos de vista.

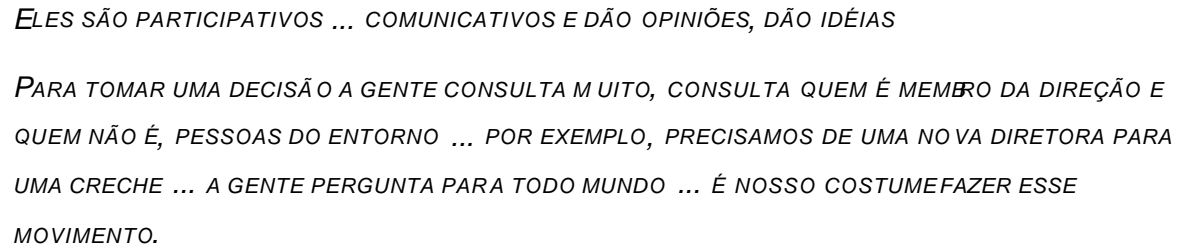

A competência contextual vem tanto pelo fato das fundadoras estarem no grupo e o influenciarem fortemente, quanto pelo fato das conselheiras estarem realizando atividades específicas e manterem-se em contato com a realidade instituci onal. Assim, a cultura institucional é primariamente vivenciada, ao invés de transmitida formalmente:

ELA IA EM TODAS AS AUDIENNCIAS, TER UMA POSIÇÃO FIRME, SER SOLIDÁRIA COM AS EDUCADORAS ...

PORQUE ELA ERA GERENTE... ELA É DUPLAMENTE RESPONSÁVEL: POR SER GERENTE E POR SER

PRESIDENTE ... EU ACHEI BACANA O JEITO QUE ELA LEVOU: CHOROU MUITO, SE DESCABELOU, FOI

DIFÍCIL ... EU ACHEI BACANA QUE ELA LEVOU O PROCESSO ATÉ O FIM...

EM FUNÇÃO DA NECESSIDADE DE ESTAR AMPLIAN DO O UNIVERSO CULTUR AL DOS NOSSOS

EDUCADORES, FIZEMOS UM GRANDE PASSEIO ... ANO PASSADO ... FOI UMA PESSOA ... ELE FAZ PARTE

DO NOSSO CONSELHO CONSULTIVO ... ELE É PROFESSOR DE HISTÓRIA.

Quanto à competência educacional, este grupo parece dar um considerável valor ao aprendizado pela convivência com os problemas e pela participação conjunta em programas de capacitação. Embora não haja nesta entidade uma avaliação formal do desempenho do conselho e dos conselheiros, algumas conselheiras tomam sistematicamente iniciativas para manterem -se à altura das suas responsabilidades $\mathrm{e}$ respondem positivamente a convites externos para participar de eventos de treinamento. Ainda, elas conscientemente utilizam erros do passado para prevenir situações futuras, como ilustrado no caso da falta de recursos.

QUANDO FUI FAZER PEDAGOGIA, EU FIZ POR SENTIR NECESSIDADE MESMO DE SE TER ESTA

FORMAÇÃO, PARA PODER FAZER O M ELHOR PARA A ENTIDADE

O GRUPO DE PROFESSORAS VAI FAZER O CURSO E EU FUI ACOMPANHANDO ... VOCÊ NÃO PÁRA DE ESTUDAR, VOCÊ SEMPRE TEM QUEIR COM QUESTÕES ... AMAIORIA DAS VEZES DÁ PARA FAZER CURSOS.

Nós ESTAMOS APRENDENDO JUNTOS ... PARA NÓS É TUDO NOVO ... A GENTE ESTÁ NESSE PROCESSO DE APRENDIZADO... SÃO PESSOAS SIMPLES MAS QUE TÊM VISÃO CLARA DESSE PROCESSO DE TRANSFORMAÇÃO, DE BUSCA ... ISSO FAZ PARTE DO NOSSO COTIDIANO.

No fim de 1999 a gente fez um CuRso que a SeCRETARIA DE ESTADO DEU ... NA ANTIGA LBA ... ELE DEU UM MODELO NOVO DE ESTATUTO. 


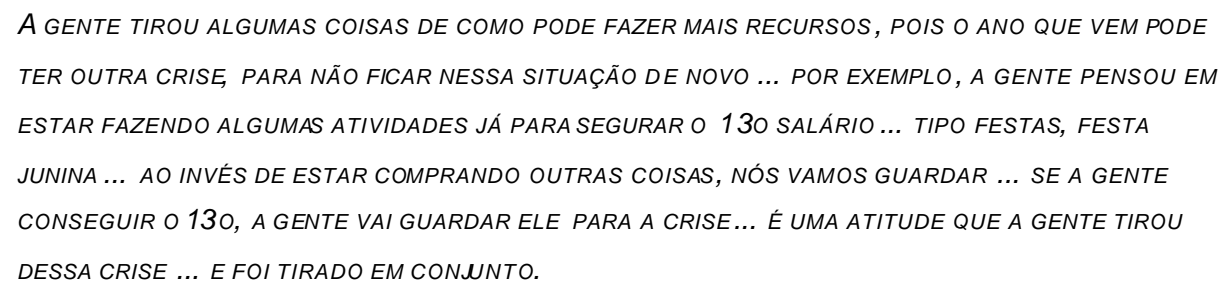

Do ponto de vista da competência estratégica, o conselho pode ser considerado o responsável pelo direcionamento da instituição: contém as fundadoras e reúne-se para decidir em conjunto as prioridades e a solução de problemas que ameaçam a sobrevivência organizacional. Vários comentários obtidos nas entrevistas demonstram uma percepção clara de prioridades, o papel ativo na redefinição do tipo de serviço prestado e a existência de uma visão institucional orientadora. Diferentemente do que indicavam as respostas dos questionários, este conselho consegue relativamente bem manter um foco institucional claro e assumir pelo menos uma prioridade válida para a entidade toda (formação).

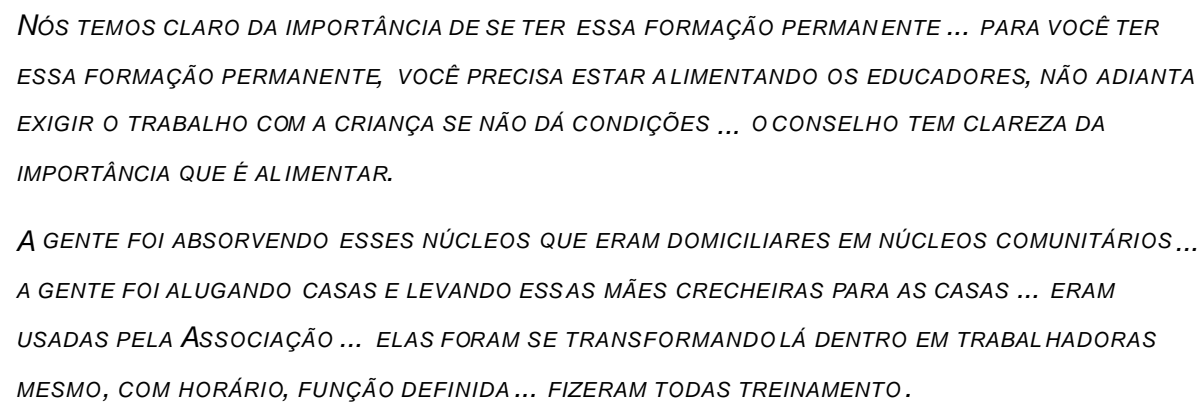

Do ponto de vista da competência interpessoal, parece um grupo coeso, que mantém boas relações e conhece-se muito bem; há encontros freqüentes e propõe-se reuniões extras quando necessário. Especialmente, este grupo consegue assumir metas muito claras, tanto em situações privilegiadas quanto difíceis, que aparentemente têm um efeito bastante positivo na entidade. $O$ processo de fomento ao surgimento de novas lideranças, entretanto, é informal.

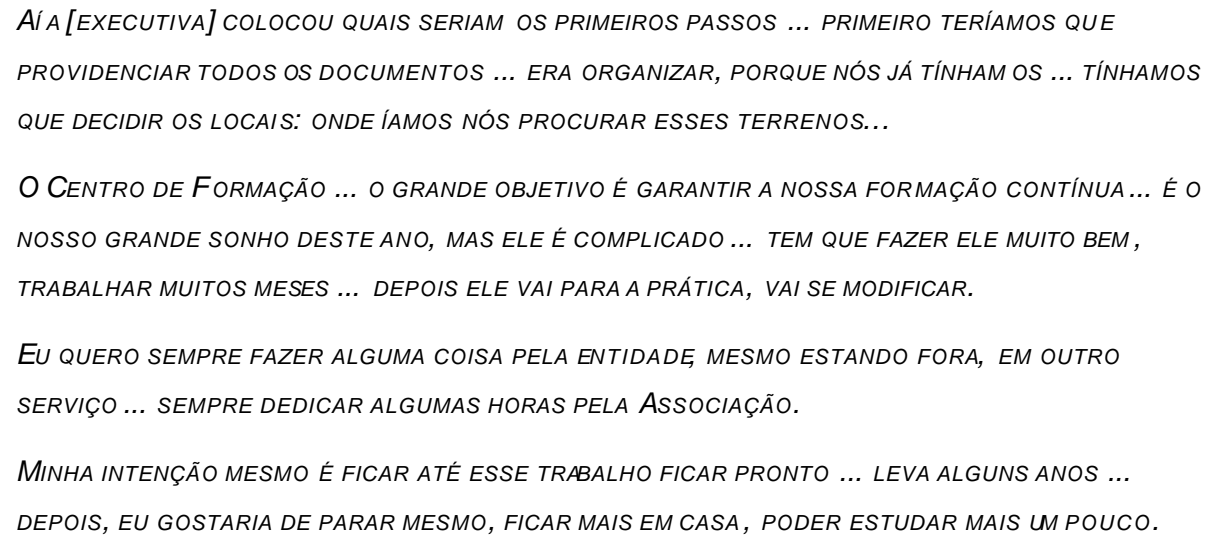

A competência política pode ser avaliada pela preocupação em nutrir relações com parceiros externos e, principalmente, em ouvir as audiências internas. No caso da construção da creche nova houve um cuidado para envolver representantes do Estado, bem como em estabelecer critérios claros para decidir qual das unidades deveria ocupar as novas instalações, por exemplo. Entretanto, esta preocupação nem sempre tem sido bem sucedida, por razões não identificadas: 


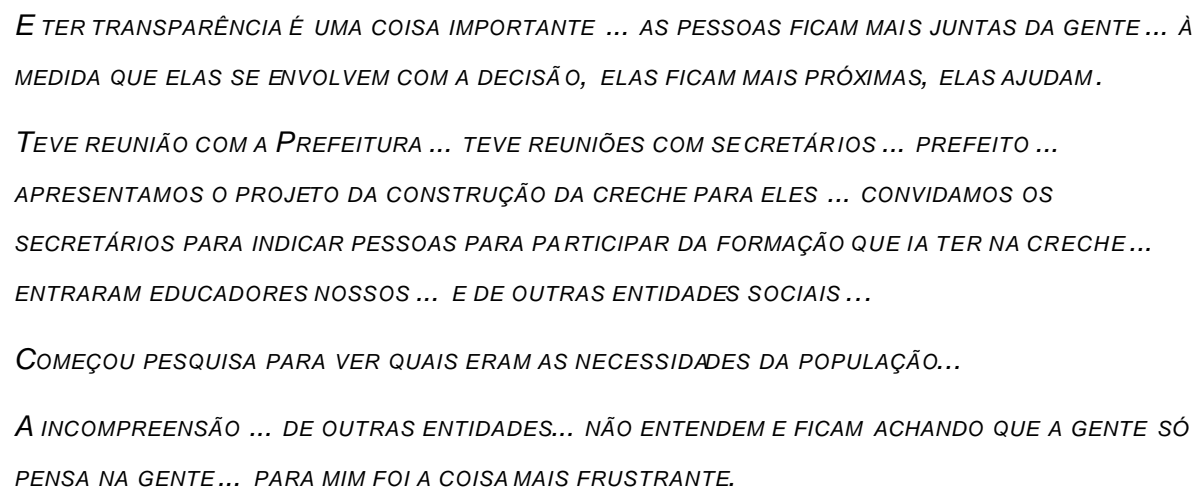

\subsubsection{ENTIDADE 5}

\subsubsection{Contexto instituctucional}

A Entidade 5 define sua missão específica como: "desenvolver uma atividade preventiva - promocional profissionalizante, conforme a inclinação de cada um”. Para realizá-la tem três centros educacionais, um centro comunitário e um bazar beneficente. É uma organização sem fins lucrativos que "iniciou seus primeiros passos em 1983" e foi constituída (segundo o estatuto) em junho de 1990.

De acordo com o estatuto, a Entidade 5 tem como finalidade:

a) colaborar na promoção integral da pessoa e sua família;

b) favorecer a implantação de uma cooperativa através de várias oficinas promocionais e profissionalizantes, para adolescentes e jovens ou para adultos desempregados;

c) planejar, realizar e ou participar de programas que visem a organização e o desenvolvimento da comunidade e adjacências.

A fundadora do Entidade 5 ainda é uma das principais lideranças voluntárias da instituição e foi a conselheira entrevistada; a liderança executiva entrevistada trabalha profissionalmente como administrador da entidade, tendo atuado anteriormente em empresas do setor financeiro. Tanto a conselheira como o executivo destacam valores e ideais ao falar do seu vínculo com a instituição, indicando um bom grau de comprometimento e motivação para exercer seus papéis.

NÃO É UM VOLUNTARIADO SIMPLES; É A MINHA MISSÃO, SOU IRMÃ MISSIONÁRIA.

De acordo com o estatuto, a entidade é administrada por:

I. Assembléia geral

II. Conselho Deliberativo

III. Diretoria Administrativa

IV. Conselho Fiscal

O Conselho Deliberativo é constituído por até 7 membros titulares e dois suplentes, eleitos a cada 2 anos, sendo responsável por eleger a diretoria administrativa, elaborar/aprovar regimentos internos, aprovar o 
plano de atividades e o orçamento anual, opinar sobre a transação com bens patrimoniais e homologar sócios efetivos. O Conselho, pelo estatuto, reúne-se ordinariamente a cada 6 meses.

A Diretoria Administrativa é eleita a cada 2 anos, sendo composta por 6 membros; compete a ela: elaborar e executar o programa e o relatório anual de atividades, entrosar-se com outras instituições, contratar e demitir funcionários e elaborar o regimento interno.

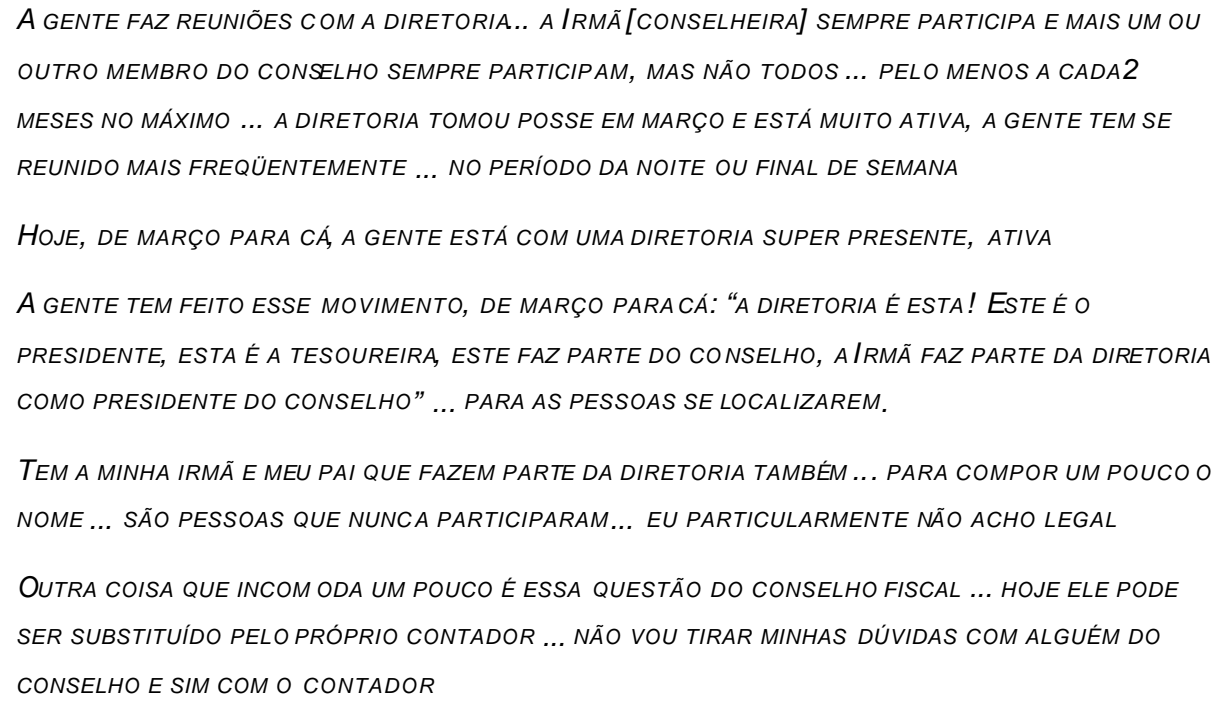

Esta entidade está aparentemente vivendo uma fase pioneira super-madura, saindo de um período em que todo o trabalho era controlado pela fundadora. A presença do administrador está trazendo novas práticas de trabalho, mais formalizadas e menos centralizadas na conselheira:

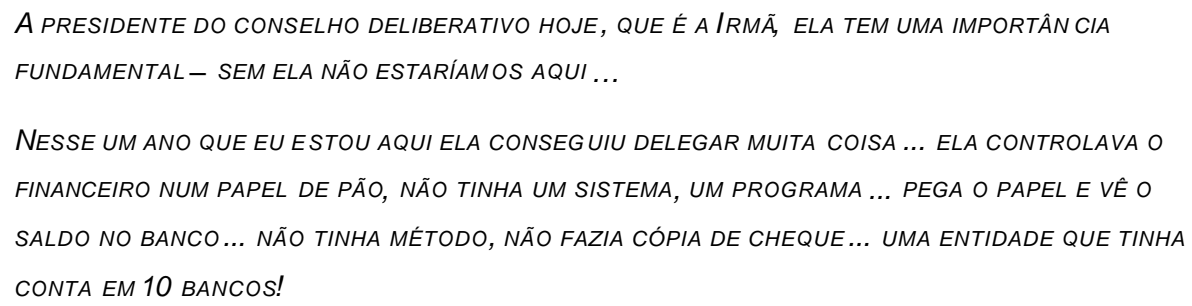

O contexto descrito é de uma organização que ainda tem na sua grande fundadora uma das suas principais lideranças, mas que lenamente vem desenvolvendo uma nova cultura institucional, baseada em novos métodos gerenciais. Neste processo, o administrador da entidade vem assumindo funções de gestão delegadas pela conselheira e esta vem podendo se dedicar mais ao trabalho técnico.

A MISSÃO DA [ENTIDADE 5], E A DIRETORIA SEMPRE CONCORDOU E SEMPRE QUIS, É FAZER PASTORAL ... NÃO TENDO UM ADMINISTRADOR, ... GABARITADO ... DE SENSIBILIDADE ... NÃO PODIA EU ME 
DEDICAR TANTO À PASTORAL ... SIGNIFICAVA DAR UM PULO DE QUALIDADE TAM BÉM PARA A PASTORAL

... ATENDER MAIS ÀS FAMÍLIAS ...

Pelo depoimento do executivo, não existe diferenciação entre diretoria e conselho na prática, ocorrendo somente "no papel", pois o conselho praticamente é pouco ativo. Durante toda a entrevista tanto ele como a conselheira se referiram à diretoria, denotando uma atividade bastante incipiente do conselho formal. A diretoria, ao contrário, é ativa, como poderá ser verificado nos casos a seguir.

\subsubsection{O Papel do Conselho nos Incidentes Críticos}

Nas entrevistas realizadas foi possível obter a descrição de 4 incidentes considerados críticos pelos respondentes:

- O processo de elaboração e implementação de um regimento interno. A diretoria participou da redação final do regimento, proposto pelo administrador recém contratado pela entidade, contribuindo para a implantação de uma nova cultura na instituição.

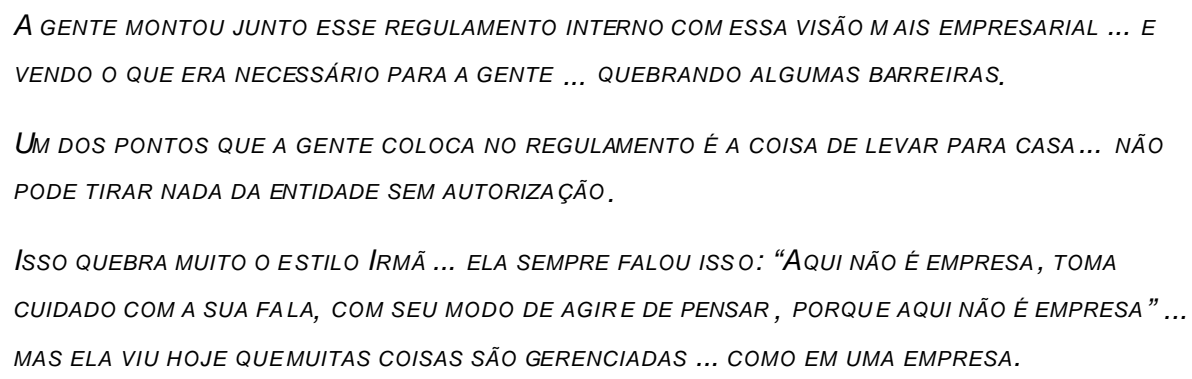

- A mudança na coordenação de um abrigo. Houve uma reunião em que a diretoria chegou a um parecer distinto do administrador quanto à demissão de uma coordenadora - a diretoria decidiu não impor uma decisão, deixando que o administrador lidasse com o caso.

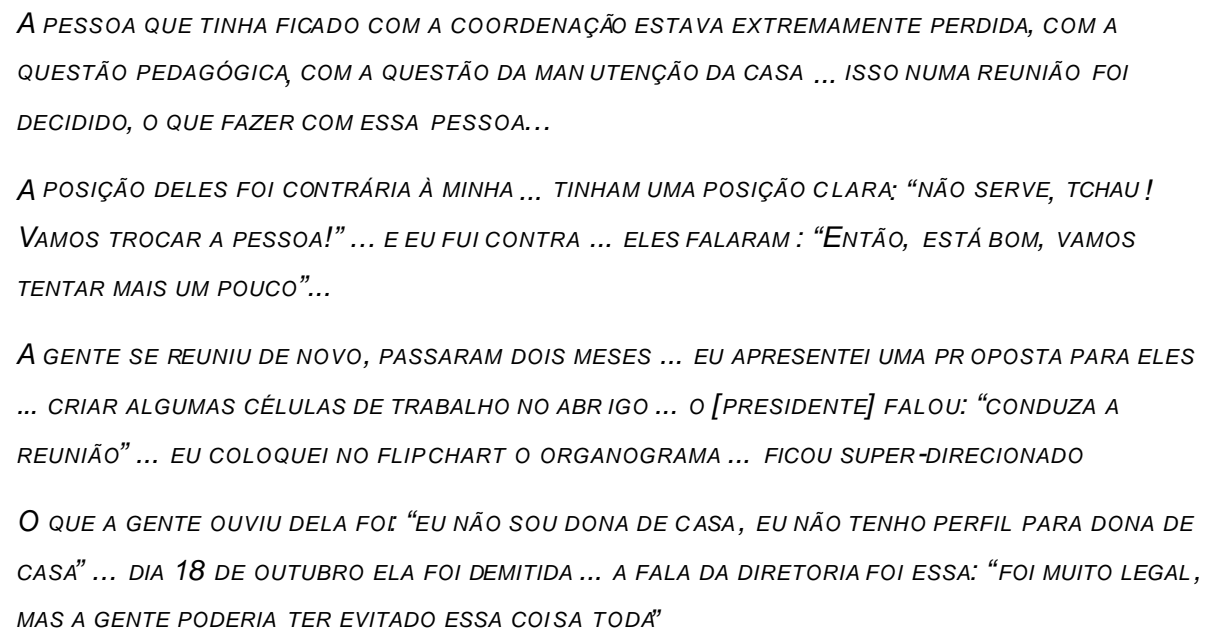

- A contratação de um administrador profissional para a entidade. A fundadora propôs a contratação de um administrador àdiretoria, que aprovou em virtude dele já ter uma experiência anterior de trabalho na entidade.

ERA UMA NECESSIDADE MUITO GRANDE, HÁ MUITO TEMPO, PORQUE A [ENTIDADE 5] CAMINHOU E CRESCEU, CRESCEU, CRESCEU ... INFELIZMENTE A GENTE TENTOU COM DUAS PESSOAS E NÃO DAVA 


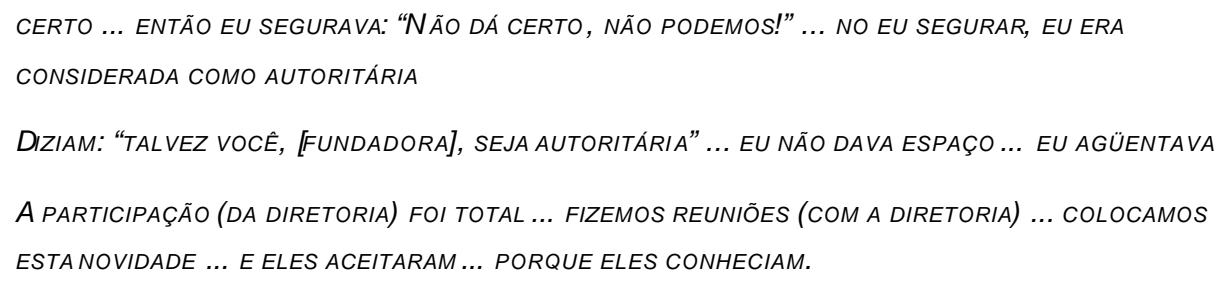

- A demissão de uma pessoa por "traição" à liderança executiva. A fundadora propôs à diretoria a demissão de uma pessoa que falava mal do administrador, ao que foi atendida, apesar da diretoria ter algumas dúvidas a respeito do contexto institucional.

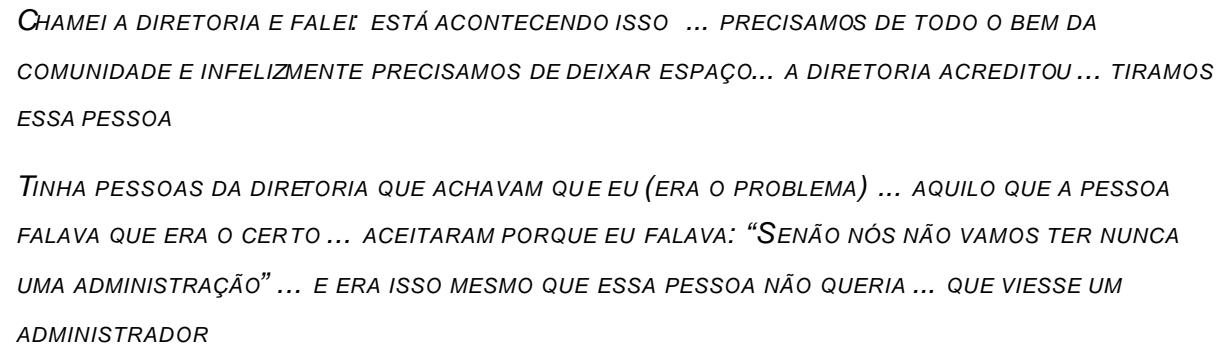

Os incidentes descritos caracterizam uma diretoria no papel de apoiadora da liderança executiva, representada pelo administrador e a fundadora (presidente do conselho). Procura manter-se distante de decisões operacionais, mas está à disposição para ajudar a pensar a respeito de decisões importantes na gestão da entidade. Fundamentalmente, a diretoria atua em grupo nas decisões, através das reuniões, tendo os diretores individuais um papel de conselheiros do administrador e da fundadora. Quanto à liderança há, portanto, dois papéis destacados nestes comentários: o papel de fundador e o papel de apoiador. O papel de apoiador é exercido pela diretoria, que faz visitas à instituição, mostra-se disponível para a liderança executiva, tem reuniões regulares e participa de discussões sempre que convocada.

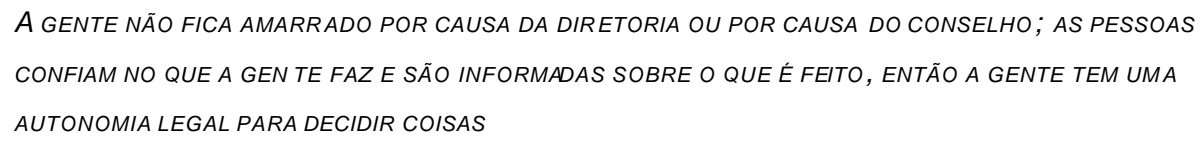

Esta diretoria vem tendo uma importância grande no estágio de desenvolvimento atual da organização: expressa-se uma tensão entre uma cultura baseada no fundador, informal e carismática, e uma nova cultura querendo emergir, com um caráter mais administrativo, formal e sistemático. A diretoria aparece facilitando o entendimento entre ambas, bem como mediando a transição de um estágio para outro. O executivo, especialmente, dá muito valor à participação dos diretores, à sua disposição em "enfrentar" uma liderança fundadora forte e à injeção de novos elementos culturais (empresariais). Assim, o principal resultado da diretoria pode ser considerado a manutenção do administrador e a adoção de princípios mais "empresariais" de trabalho. 
HoJe o [PRESIDENTE] NA PRÁTICA É FUNDAMENTAL; É MEU APOIO ... AQUELA PESSOA QUE, SE EU PRECISAR E SE EU ESTIVER COM DIFICULDADES, É A PRIMEIRA PESSOA QUE VOU LIGAR E PEDIR APOIO

... ISSO ELE JÁ DEIXOU BEM CLARO: "PRECISOU, ME PROCURE”...

Segundo os entrevistados, a diretoria conseguiu ser efetiva porque:

PORQUE PARTICIPARAM

PARTICIPAÇÃO ... NÃO NECESSARIAMENTE SÓ NAS REUNIÕES ... E ASSINATURAS DE CONVÊNIO ... AS PESSOAS VÊM NUMA BOA, VOLUNTARIAMENTE ... VÊM PARA BATER PAPO E VER COMO AS COISAS ESTÃO ANDANDO

PoRque tRouXERAM MÉtodos EMPRESARIAIS ... ISSO ME AJUDOU A QUEBRAR ALGUMAS BARREIRAS ... SEM FERIR AS PESSOAS

A EXPERIÊNCIA DELES COM ESSA QUESTÃO ORGANIZACIONAL - É DIFÍCIL VOCÊ VER ORGANOGRAMA NAS ENTIDADES ... ISSO ELES VIVEM ... ISSO VIROU UM POUCO CULTURA DA ENTIDADE ...

FOI EFICAZ PORQUE MAIS UMA VEZ ATUOU JUNT O NAS MUDANÇAS... NÃO É FÁCIL QUANDO VOCÊ MEXE COM UM QUADRO DE PESSOAL ... TODA MUDANÇA GERA SATISFAÇÃO OU INSATISFAÇÃO

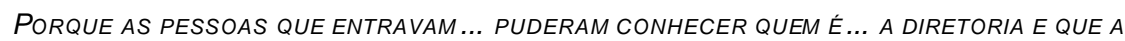
DIRETORIA É E ESTÁ PRESENTE

Confiança RECÍPROCA ... PESSOAS CORRETAS, PRECISAS, COERENTES

O NÍVEL CULTURAL DA PESSOA ... OUTRA DIRETORIA ... A PRIMEIRA FRASE QUE OUVIFOI: "SE VOCÊ VEIO AQUI PARA SE CANDIDATAR A ALGUM CAR GO POLÍTICO, FORA!”...

Em síntese, a Entidade 5 é uma organização que no papel tem diretoria e conselho, mas na prática existe um grupo que administra o dia-a-dia e outro que se preocupa em dar apoio e preservar a identidade institucional. A liderança da fundadora é forte, mas está havendo uma transição de uma fase fundadora para uma fase diferenciada. A presença e a atuação do executivo, administrador profissional, bem como a legitimidade e o caráter empresarial da diretoria parecem ser fatores favoráveis a isso.

\subsubsection{Competências desenvolvidas}

Assim, parece que na prática a diretoria consegue expressar as seguintes competências:

Competência analítica: aparentemente a diretoria é cuidadosa ao tomar decisões, discutindo bastante para decidir, mostrando-se disposta a trabalhar com diferenças de opinião e procurando ouvir mais de uma pessoa, especialmente a equipe técnica. Porém, embora bastante franca a respeito do possível papel autoritário da fundadora, a maneira como a diretoria tratou do assunto pareceu opinativa (e não investigativa) e inconseqüente (e não num papel de responsável).

QUANDO A GENTE PRECISA DA PARTICIPAÇÃO DAEQUIPE TÉCNICA, A GENTE MARCA OU UM FERIADO QUE ESTÁ PERTO OU FIM DE SEMANA ... AS REUNIÕES AÍ DEMORAM UM POUCO MAIS

A GENTE DISSECOU TODOS OS CAPÍTULOS DO REGULAMENTO JUNTO COM ELES E FIZEMOS AS ALTERAÇÕES NECESSÁRIAS ... AGREGOU MUITO COISA QUE EU NÃO TINHA COLOCADO ... AGREGOU UM CAPÍTULO MUITO INTERESSANTE DA IRMÃ ... ESSA COISA DE RELAÇÕ ES HUMANAS

DIZIAM: "TALVEZ VOCÊ, [IRMÃ], SEJA AUTORITÁRIA"... 
Competência contextual: a diretoria e o administrador conhecem bem os valores e as tradições da organização, representando tanto forças para alterar a cultura institucional quanto para fortalecê-la. Como já foi dito, há uma tensão inerente ao estágio de desenvolvimento da organização, que está se profissionalizando - a diretoria tem mostrado bastante competência contextual tanto ao questionar alguns princípios tradicionais, como ao lutar pela manutenção de outros. Aparentemente, esta competência contextual tem garantido a devida legitimidade aos diretores em discussões com a fundadora. Ao participar da redação do regimento interno e ao identificar-se regularmente na entidade, a diretoria tem agido de forma a exemplificar alguns dos novos valores institucionais, denotando esta competência. Pelos depoimentos, finalmente, consegue-se perceber que novos valores coexistem com valores tradicionais da entidade sem conflitos (porém, com tensões), também indicando uma certa competência contextual.

Por outro lado, esta entidade parece que lentamente vem criando e fortalecendo mecanismos formais de transmissão dos valores institucionais, através das reuniões de diretoria, da adoção de um regimento interno e das visitas dos diretores às unidades.

HOJE, DE MARÇO PARA CÁ, A GENTE ESTÁ COM UMA DIRETORIA SUPER PRESENTE, ATIVA ... TAMBÉM PORQUE O PRESIDENTE DA ENTIDADE... É EMPRESÁRIO, TEM UMA VISÃO LEGAL ... CONHECE A [ENTIDADE 5] HÁ MUITO TEMPO ... MORA PRÓXIMO ... E É UMA PESSOA COMPROMETIDA COM A CAUSA $\cdots$

ISSO TEM ME AJUDADO MUITO, PORQUE A FALA DA GEN TE É MUITO PARECIDA; SAI DAQUELA COISA MUITO PATERNALISTA ... E QUEBRA ALGUNS PONTOS QUE EMPERRAM O PROCESSO ... NÃO É PORQUE É ENTIDADE FILANTRÓPICA QUE NÃO TEM QUE SER COBRADO HORÁRIO DE TRABALHO ... EXISTE UM CONTRATO DE TRABALHO

EXISTEM ALGUMAS SENHORAS DO BAIRRO QUE JÁ PARTICIPARAM EM OUTROS MOMENTOS DA DIRETORIA ... QUE TÊM UMA HISTÓRIA LEGAL ... VIRAM A [ENTIDADE 5] COMEÇAR ... PARTICIPARAM MUITO COM A IRMÃ DE TODAS AS DIFICULDADES QUE TIVERAM ... ELAS COMEÇAM A CONTAR UMAS HISTÓRIAS QUE NÃO DÁ PARA ACREDITAR... É UMA HISTÓRIA VIVA ... VOCÊ LIGA PARA REUNI ÃO, ELAS COMPARECEM... SÃO ATIVAS

QUANDO VOCÊ LÊ ALGUMAS COISAS, PARA A IRMÃ AQUILO SOA MUITO PESADO ... O CAPÍTULO DAS PROIBIÇÕES ... EU CONSEGUI FORÇA PARA EDITAR ISSO COM A DIRETORIA ... FALANDO PARA ELA QUE TEM QUE EXISTIR PROIBIÇÃO ELA TEM A HISTÓRIA DA VIDA DA ENTIDADE E A FIGURA DELA É MUITO CONHECIDA E MUITO IMPORTAN TE PARA A[ENTIDADE 5] ...

Competência educacional: infelizmente não foi possível identificar qualquer fato que revelasse competência nesta dimensão, exceto pelas respostas aos questionários, as quais foram bastante divergentes entre os dois entrevistados ( $28 \%$ pelo executivo e $75 \%$ pela conselheira).

Competência estratégica: embora digam respeito pouco à missão e aos objetivos institucionais, os incidentes descritos podem ser considerados como de importância estratégica para a entidade simplesmente porque eles se referiram, todos, a um processo de amadurecimento organizacional, à construção de um ambiente capaz de suportar uma nova cultura. Deste ponto de vista, a diretoria demonstrou um bom grau de competência estratégica, a ponto de "peitar" a fundadora. Do modo como agiu, a diretoria sustentou o direcionamento da evolução institucional para um patamar de maior profissionalização. 
Este ponto é importante porque adiciona um ingrediente importante à competência estratégica, que é a capacidade de identificar e compreender o processo de desenvolvimento da organização e tomar atitudes e decisões que o facilitem, ao invés de minálo.

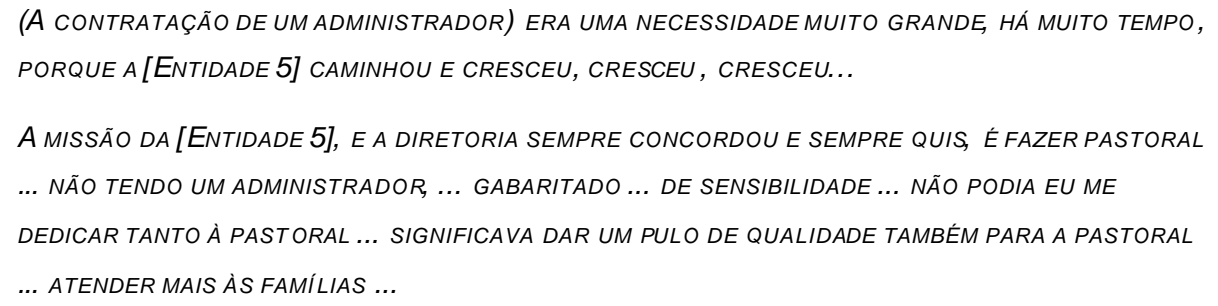

Competência interpessoal: como em outras organizações, as questões de sucessão e mandato parecem ser tratadas como secundárias. A competência interpessoal advém da capacidade que a diretoria vem mostrando, pelo que sugerem os depoimentos, de confrontar sem romper ligações, de reconhecer esforços bem sucedidos e de procurar tomar decisões coletivamente.

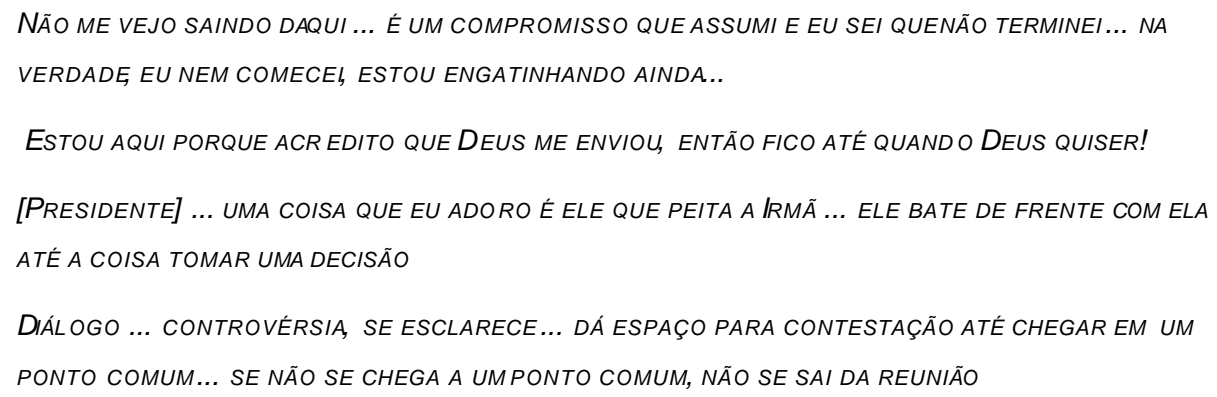

Competência política: a diretoria reconhece claramente a importância do papel do administrador e da fundadora e respeita sua integridade. Procura trabalhar junto com a equipe e comunicar-se diretamente com ela. De fato, a diretoria "atuou junto nas mudanças", com uma competência política significativa ao respeitar a opinião e posição do executivo e ao convidar a equipe técnica a participar de reuniões. Tal como em outras entidades, entretanto, pouca ênfase é notada ao relacionamento com públicos externos àentidade.

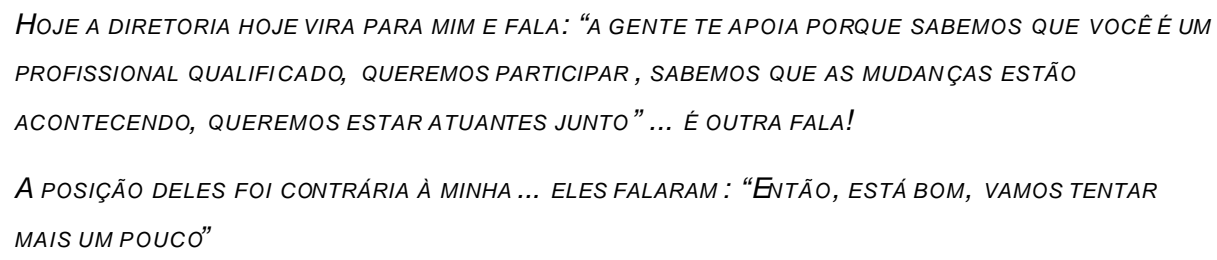

\subsubsection{ENTIDADE 7}

\subsubsection{Contexto institituncionnal}

A Entidade 7 é ligada a uma instituição internacional muito antiga, tendo sido fundada no Brasil em 1957; o público beneficiário é de baixa renda, da região Sul da Grande São Paulo. A Entidade 7 tem um "vasto programa de promoção e assistência", atuando nas áreas da saúde (com um grande centro médico sócio educativo), creches e centros de juventude; já recebeu o Prêmio Bem Eficiente duas vezes. "Uma das 
características mais marcantes do atendimento prestado é o de ser totalmente gratuito e feito, em grande parte, por voluntários.

De acordo com os estatutos, são fins primordiais da Associação:

1. A proteção e o socorro aos enfermos e necessitados;

2. A educação popular;

3. A prestação de serviços assistenciais;

4. A contribuição moral e espiritual em toda e qualquer obra humanitária.

As entrevistas foram realizadas com a coordenadora assistencial - a principal liderança executiva da entidade- e com um conselheiro. A coordenadora dedicase em tempo integral àinstituição:

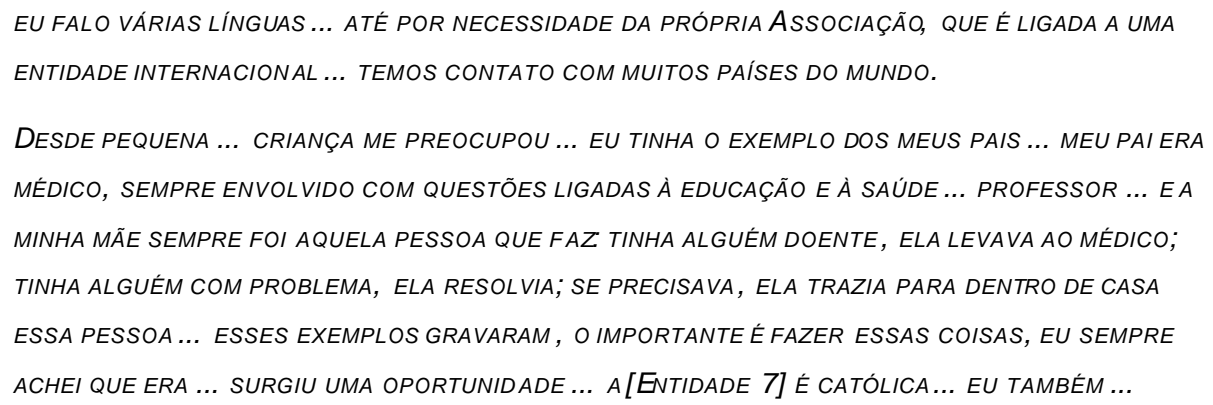

O conselheiro está ligado à entidade há cerca de 20 anos e é empresário do ramo têxtil. Pelos comentários feitos, tanto uma, quanto o outro aceitaram fazer parte da organização por identificar-se com sua causa e com seus valores e princípios.

MAIS A DISPOSIÇÃO EM AJUDAR E DE SER ÚTIL... A[ENTIDADE 7] EM OUTROS PAÍSES É UM TROÇO ELEVADÍSSIMO... NA ITÁLIA SÓ ENTRAM NOBRES... NA ALEMANHA MUITOS NOBRES E MUIT OS VOLUNTÁRIOS ... MAIS DE 100.000 VOLUNTÁRIOS

A coordenadora é parte de um grupo de lideranças "novas" surgidas na entidade no final dos anos 60:

COMO INSTITUIÇÃO INTERNACIONAL, A PESSOA É CONVIDADA A PARTICIPAR ... MEU MARIDO FOI CONVIDADO... SE INTERESSOU ... NA ÉPOCA A ATUAÇÃO DA ASSOCIAÇÃO DE SÃO PAULO ERA BASTANTE LIMITADA... 1969 FOI QUANDO ELE ENTROU, A ASSOCIAÇÃO FOI FUNDAD A EM 1957 ... NO INÍCIO ERA UM GRUPO PEQUENO ... QUANDO ELE ENTROU, ELE E O GRUPO QUE ENTROU COM ELE ERAM OS JOVENS NA ÉPOCA - RESOLVERAM DINAMIZAR ... VAMOS FAZER UMA COISA BEM ORGANIZADA, PARTINDO DO BEM PEQUENO

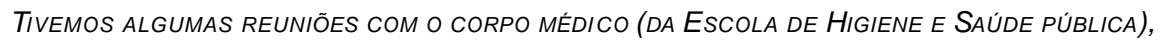
ELES NOS ORIENTARAM DE COMO FAZER ESTE TRABALHO, DE COMO COMEÇAR ... ELES ENTÃO FALARAM: VOCÊS TÊM QUE FAZER UMA AÇÃO BÁSICA, PRINCIPALMENTE DE PR EVENÇÃO DE SAÚDE, DANDO PRIORIDADE À I NFÂNCIA ... ENTRAR EM CONTATO COM O ÓRGÃO DA SECRETARIA DE SAÚDE DA REGIÃO, PARA TER UM PONTO DE APOIO, PARA FAZER PARTE DE UM GRUPO ...

AÇÕES PREVENTIVAS ... EDUCAÇÃO DAS MÃES, CONSULTA PEDIÁTRICA EVITANDO QUE A CRIANÇA FIQUE GRAVEMENTE DOENTE ... COMEÇOU ASSIM ... CONSEGUIU-SE COMEÇAR COM UM GRUPO DE VOLUNTÁRIOS ... AUMENTOU-SE O NÚMERO DE PESSOAS DA ASSOCIAÇÃO QUE ENTUSIASMARAM-SE TAMBÉM, AOS POUCOS FOMOS CONSEGUINDO UMA SEDE PR ÓPRIA ... E AMPLIANDO ESSES SERVIÇOS SEMPRE EM TORNO DA FAMÍLIA... 
Segundo os estatutos, a Associação é administrada por uma diretoria eleita em assembléia dos sócios efetivos, com mandato de 3 anos, podendo ser reeleita, com exceção do presidente, que não poderá ser reeleito por mais de duas vezes consecutivas. Há um conselho consultivo, também com mandato de 3 anos e composto de no máximo 15 membros, que assiste a Diretoria. O conselho da Entidade 7 tem na prática 10 membros, que reúnem -se mensalmente; seus membros são chamados Conselheiros da Associação. Existe também um conselho fiscal, composto por 5 membros efetivos e 2 suplentes.

O conselho foi formado, na visão da coordenadora, em resposta ao interesse de algumas pessoas:

NO COMEÇO A DIRETORIA DA ASSOCIAÇÃO TINHA UM NÚMERO MAIS LIMITADO, MAS O PRÓPRIO

INTERESSE DE PESSOAS ... FIZERAM COM QUE ELES QUISESSEM PARTICIPAR DA DIREÇÃO ... ENTÃO

AGREGAMOS MAIS PESSOAS INTERESSADAS EM A JUDAR FORMANDO UM CONSELHO ... CONVIDAMOS ...

O perfil dos conselheiros, segundo os entrevistados, é:

EXECUTIVOS ... DONOS DE EMPRESAS OU PESSOAS QUE TEMM ALT OS CARGOS ADMINISTRATIVOS OU

EXECUTIVOS DE EMPRESAS... A MAIORIA É ACIMA DE 50 ANOS ... CLASSE ALTA ... EM MÉDIA SÃO

PESSOAS QUE FAZEM PARTE DA ASSOCIAÇÃO HÁ MAIS DE 20 ANOS ... ESSES QUE FICAM NA DRETORIA

SÃO OS MAIS ANTIGOS ... NORMALMENTE SÃO PESSOAS QUE JÁ ESTÃO HÁ MUITO TEMPO

OS ELEMENTOS SÃO ESCOLHIDOS POR SEREM ... CATÓLICOS ... ATUANTES... VIDA NORMAL DE LAÇOS

MATRIMONIAIS E FILHOS ... E EM FUNÇÃO DAQUILO QUE JÁ FOI NO SENTIDO ASSISTENCIAL ... O LEMA É:

"MANUTENÇÃO DA FÉ, DAR AOS POBRES"... A GENTE TEM QUE SE GUIAR.

\subsubsection{O Papel do Conselho nos Incidentes Críticos}

Os incidentes relatados pelos entrevis tados diziam respeito a diferentes situações, sintetizadas a seguir:

- Negociação da cessão de um terreno pela prefeitura, para construção de um novo prédio de atendimento. $O$ conselho realizou reuniões para decidir sobre qual o tamanho do terreno a ser soliditado e ofereceu apoio nos trâmites para a aprovação do projeto junto àprefeitura.

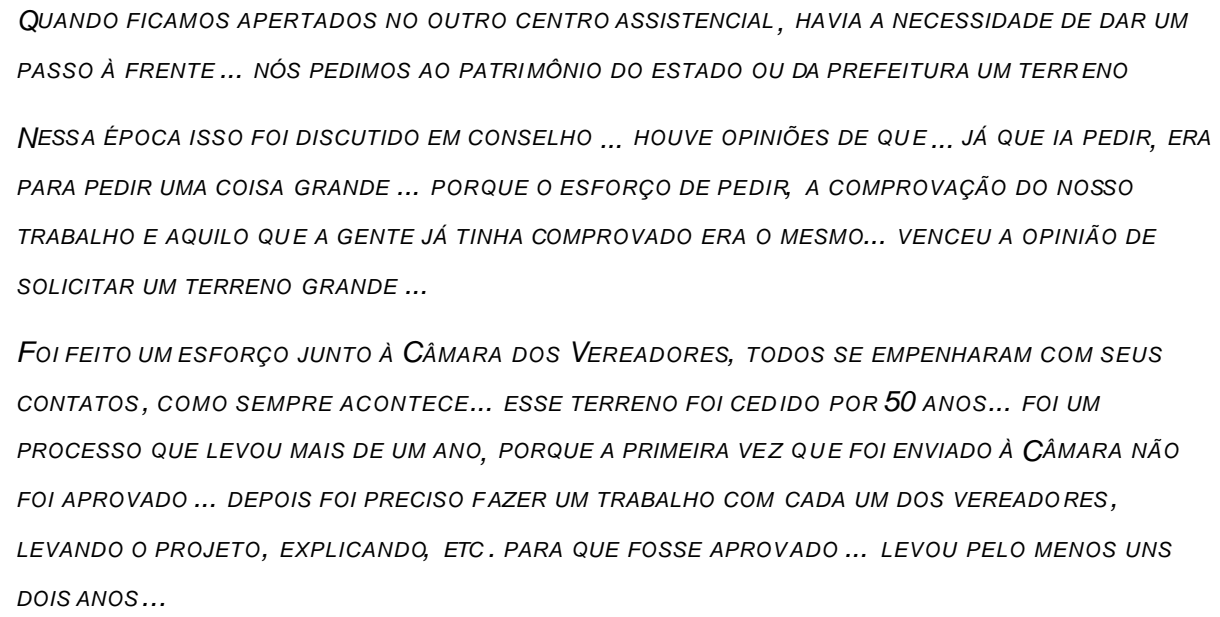

A CONStRuÇÃo FoI UM ASSUNTO DEBATIDO AMPLAMENTE ... TAMANHO, FINALIDADE, ETC.

- Dimensionamento de uma feira beneficente com artigos importados. O conselho realizou estudos e discussões para avaliar os riscos de um grande investimento na feira, cujo objetivo final era gerar fundos para a construção do novo centro de atendimento. 
TINNHAMOS UMA LICENÇA DO GOVERNO FEDERAL PARA QUE ISSO ENTRASSE SEM PAGAMENTO DE IMPOSTOS ... É SEMPRE A MESMA HIS TÓRIA: VAMOS PEGAR " $X$ " MERCADORIAS OU MUITO MAIS? ... UM DOS MEMBROS DA DIRETORIA OU DO CONSELHO FALOU: "NÃO, VAMOS PENSAR GRANDE, VAMOS PEDIR MAIS!"

COM ESTE PENSAMENTO SE FEZ FEIRAS MAIORES DO QUE PREVISTO INICIALMENTE E SE CONSEGUIU UM FUNDO QUE POR VÁRIOS ANOS NOS AJUDOU BASTANTE ... O DINHEIRO FOI APLICADO, CONSEGUIUSE FAZER ESSE FUNDO PARA CONSTRUIR O PRÉDIO, ETC.

EU SEMPRE TENHO MAIS M EDO ... SERÁ QUE A GENTE VAI CONSEGUIR VENDER? ... VAI OUTRO E FALA: E ONDE VAI PÔR? ... UM FALA: TEM UM DEPÓSITO... VOCÊS PODEM COLOCAR LÁ ... ESPECIFICAMENTE HAVIA UNS QUE INSISTIAM, MAS OS OUTROS CONCORDARAM

RISCO ... ELES CALCULARAM ... FOI UM ESTUDO MESMO PROFISSIONAL, NO SENTIDO DO CUSTOBENEFICIO DISTO ... NUMA DAS ÚLTIMAS FEIRAS CHEGARAM A IR DOIS DIRETORES PARA A EUROPA, PARA VER AS MERCADORIAS, O QUE SERIA MAIS INTERESSANTE ... EM NÚMEROS, VER O QUE NÓS VAMOS TER DE VANTAGEM ... QUAIS OS CUSTOS? ... QUAL O RISCO DE MERCADORIA EMPATAR?QUAL O PERCENTUAL QUE PODERÁ NÃO SER VENDIDO? HÁ POSSIBILIDADE DE SE DETERIORAR OU NÃO? ... HÁ UM ESTUDO À FUNDO, NÃO É IMPROVISADO ... HAVIA UM ESTUDO APROFUNDADO DOS PREÇOS DO MERCADO, QUANTOS POR CENTO DEVERIA SER MAIS BARATO, DE QUE FORMA ISSO IA TER QUE SER DIVULGADO ... LEVAVA VÁRIOS MESES, HAVIA UM ESTUDO...

- Aprovar a proposta da liderança executiva de começar um centro de juventude. O conselho foi solicitado a aprovar a abertura de um novo ti po de atendimento na entidade e a contribuir para viabilizá-lo.

NÃO ESTAVA PREVISTO O CENTRO DE JUVENTUDE NO NOSSO PROJETO INICIAL, QUE ERA CRECHE E CENTRO MÉDICO SÓCIO-EDUCATIVO ...

NÓS TÍNHAMOS AS CRIANÇAS ATÉ 7 ANOS E QUANDO ELAS SAÍAM DA CRECHE, IAM PARA A ESCOLA ... MAS FOI MUDANDO ... TIVEMOS UM CASO DE U M MENINO NOSSO ... COM 8 ANOS FOI PEGO NUM ASSALTO À MÃO ARMADA... FOI PARA A FEBEM, CONSEGUIMOS TIRAR... TENTAMOS CONVENCER A MÃE E ELA DISSE: SE VOCÊS FICAREM COM ELE, TUDO BEM ... ENTÃO DURANTE O DIA ELE FICAVA AQUI (EU DISSE:) NÃO PODEMOS ACEITAR ISSO, TEMOS QUE ACOLHER ESSA CRIANÇA DE ALGUMA FORMA ... NÓS VAMOS FAZER UM CENTRO DE JUVENTUDE ... QUE A CRIANÇA FICA MEIO PERÍODO E O OUTRO MEIO PERÍODO FICA NA ESCOLA ... NÓS NÃO TÍNHAMOS OS RECURSOS DAS FEIRAS ... FOI FEITO DE UMA FORMA PRECÁRIA...

HOUVE UMA CERTA REAÇÃO ... NO CONSELHO, NÃO TANTO ENTUSIASMO ... NÃO FOI UM QUESTIONAMENTO QUE EU NÃO PUDESSE REBATER ... EU IA CONVENCÊ-LOS! EU VOU PARA UM LADO, VOU PARA O OUTRO E VOU CHEGANDO LÁ... ISSO AI NÃO PODE DEIXAR DE SER FEITO...

- Aprovar a proposta de estabelecer convênios com a Universidade. A liderança executiva, no caso a coordenadora, levou ao conselho uma proposta para financiar equipamentos e pessoas na Universidade, bem como no próprio ambulatório da entidade.

COM FUNDOS DA ITÁLIA ... PARA COMBATE À CATARATA PREMATURA DE CRIANÇAS ...

ANTES DE ACEITAR, PRIMEIRO FALAR COM OS OUTROS PARA VER SE TOPARIAM ... E DEPOIS

ACERTARMOS AS RESPONSABILIDADES PELA BOA APLICAÇÃO DOS FUNDOS ...

- Adoção de uma nova estratégia de captação de recursos. O conselho decidiu realizar um evento inovador na entidade para arrecadar recursos de novas fontes. 
NUNCA FIZEMOS ... VAMOS TIRAR DINHEIRO DE GENTE GRAÚDA ... COM JANTAR DE 500 ANOS DE BRASIL ... CONVIDADOS "N", DE PESO, UMA COISA DE GALA, ONDE TODO MUNDO QUEIRA APARECER, PAGANDO O PREÇO..

O CONSELHO ACONSELHOU: VAMOS FAZER! ... NUNCA FOI FEITO ISSO ... VAMOS VENDER ... SOU OBRIGADO A VENDER CONVITES ... TODOS VÃO ... QUER DIZER, NEM TODOS, PORQUE TEMOS MEMBROS MEIO CAPENGAS, IDOSOS

A forma de atuação deste conselho, que se confunde muito com a diretoria, é claramente baseada em decisões coletivas e esforços individuais. Há reuniões regulares, mensais, em que se discutem assuntos diversos ligados à vida institucional, com grande atenção para a sustentação financeira da entidade. Aparentemente estas reuniões são fóruns de discussão, onde os participantes podem expor idéias e opiniões livremente. Uma vez tomada uma decisão coletiva, alguns conselheiros, de acordo com o assunto, colocam-se à disposição da liderança executiva e a auxiliam alguns processos com sua influência ou talento pessoal.

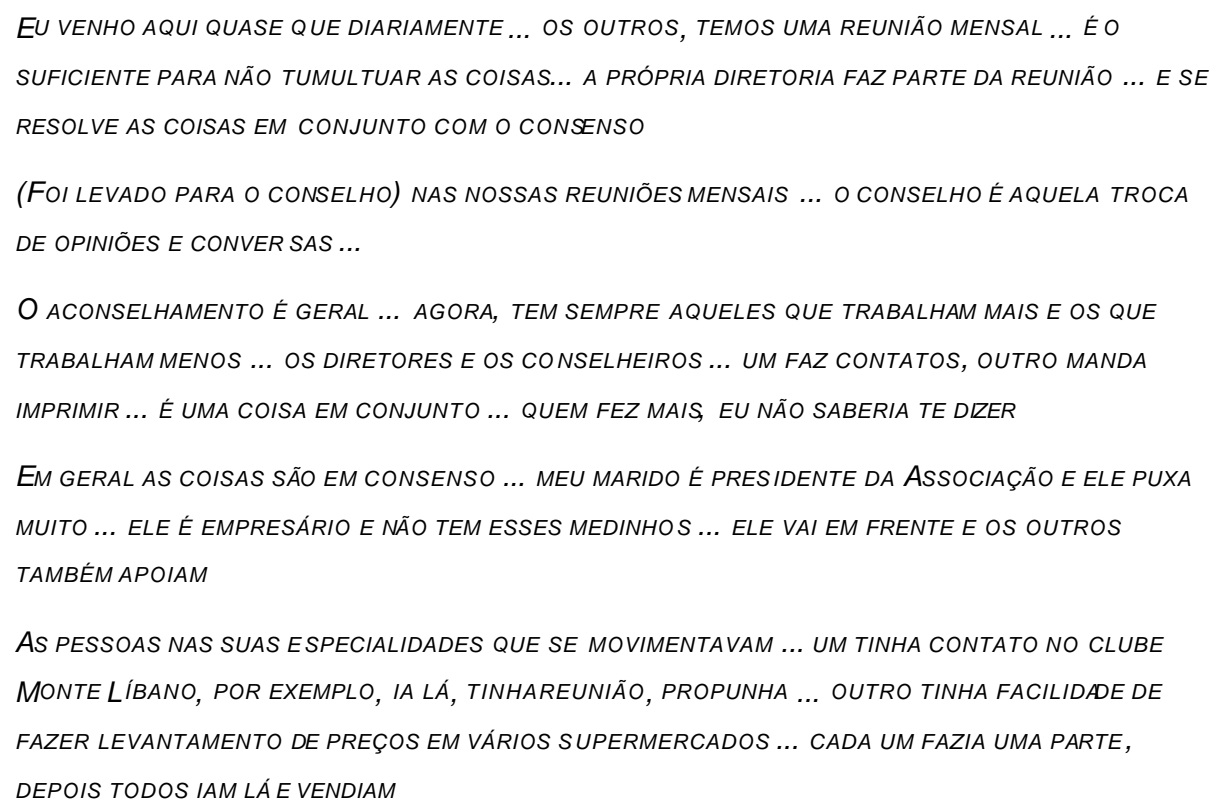

Dessa forma o conselho é importante como co-responsável pela iniciativa, como apoiador, como "abridor de portas" e como guardião da visão de futuro institucional e seus valores. O conselho não assume um papel rígido de controlador, fiscalizador ou de tomador de decisões; ao contrário, dispõe-se a assumir uma meta e providenciar os meios ao seu alcance para realizá-la. Claramente, sua existência no mínimo melhora a qualidade das decisões que são tomadas.

É MUITO IMPORTANTE TER UM GRUPO DE PESSOAS QUE DIVIDEM A RESPONSABILIDADE ... UMA ORGANIZAÇÃO DESSE TAMANHO NÃO PODE FICAR COM UMA PESSOA SÓ, ESSA RESPONSABILIDADE TEM QUE SER COMPARTILHADA COM PESSOAS DE UM CERTO NÍVEL QUE POSSAM ASSUMIR ESSA RESPONSABILIDADE..

SEM O CONSELHO SERIA UMA RESPONSABILIDADEMUITO GRANDE DA DIRETORIA E DO PESSOAL QUE ATUA ... É UM DOS MOTIVOS DA EXISTÊNCIA DE UM CONSELHO: TANTO A RESPONSABILIDADE, COMO ALIVIAR A PARTE EXECUTIVA. 
SEMPRE TIVEMOS A INFLUÊNCIA BENÉFICA DO CONSELHO ... DE UMA CERTA FORMA É UMA TROCA DE IDÉIAS, É UM APORTE QUE ESSA S PESSOAS PODEM DAR ... CADA UM TEM UMA CONTRIBUIÇÃO ...

TROCAMOS IDÉIAS... TRABALHANDOJUNTOS

Não há na prática, pelos depoimentos dados até aqui, uma distinção clara entre o papel do conselho e o papel da diretoria (considerando que a coordenadora assistencial não é parte da diretoria). Há, sim, um grupo de pessoas voluntárias, comprometidas com a organização, que se reúnem para ajudar a pensar sobre questões importantes e a viabilizar que as idéias surgidas sejam implementadas. Este grupo vem tendo uma importância grande na Entidade 7.

NÃO TEMOS PRESIDENTE DO CONSELHO, É UM CONJUNTO...

O conselho parece manter uma relação de bastante respeito e abertura com a principal liderança executiva: é uma relação em que se dá espaço para cada um manifestar sua vontade e de tentar convencer o outro. Isso parece contribuir para que a executiva sinta-se à vontade para expressar sua visão, sua vontade e seus motivos de maneira direta para o conselho.

Em termos de resultados, pode-se considerar que o conselho, pelas descrições obtidas, contribuiu pelo menos para:

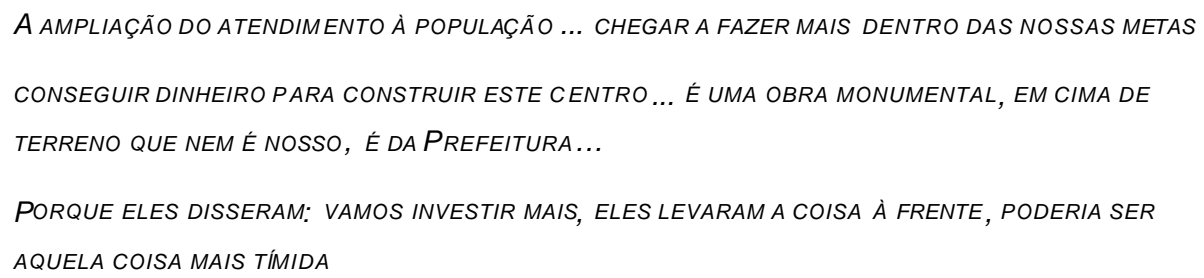

Em síntese, este conselho acompanha o que acontece na instituição, através de visitas locais, reuniões regulares e do envolvimento em tarefas específicas orientadas por uma meta. É um grupo que decide junto, por consenso, quando necessário faz análises bastante técnicas e utiliza seus contatos pessoais para facilitar os projetos da instituição. É um grupo com duas lideranças fortes (a coordenadora assistencial e seu marido), que opera com um grau significativo de informalidade, há muito tempo, que compartilha de valores comuns e provavelmente pertence à mesma camada social. Os valores compartilhados, a liderança exercida pelo presidente do conselho, a relação de respeito entre os conselheiros, o sistema de trabalho assumido, a experiência empresarial que têm e o engajamento da coordenadora são fatores que contribuem para que este conselho seja efetivo.

(O PRESIDENTE DO CONSELHO) É MUITO IMPORTANTE, PORQUE É UMA FIGURA QUE AGLUTINA ...

NOSSO CONSELHO É COMPOSTO POR PESSOAS DE VÁRIOS TIPOS DE ATIVIDADES, QUE TALVEZ NEM SE

CONHECESSEM SE NÃO FOSSE POR CAUSA DA ASSOCIAÇÃO ... MEU MARIDO JÁ ESTÁ NA PRESIDÊNCIA

HÁ MUITOS ANOS ... AS PESSOAS O TÊM COMO REFERÊNCIA

O PRESIDENTE DA ASSOCIAÇÃO É O MARIDO DELA ... ELE É UMA DAS GRANDES MOLAS DO NEGÓCIO,

MAS ELA É A QUE REALMENTE FAZ A COISA FUNCIONAR

\subsubsection{Competências desenvolvidas}

Este conselho mostra um bom nível de competência analítica, pela importância que parece dar a análises técnicas. O processo analítico é informal e natural, favorecido por uma aparente cultura da busca da solução, não do problema ou impedimento. No incidente da feira beneficente o conselho tomou cuidado 
tanto para decidir sobre o investimento, quanto para que este investimento desse certo. Neste processo chama a atenção a quantidade de perguntas citadas pelos entrevistados, denotando que há espaço para o surgimento de idéias novas e questionamento.

Outro aspecto relevante, do ponto de vista analítico, é que havia um "projeto inicial" - construído após consulta a especialistas - utilizado como parâmetro para a tomada de decisões.

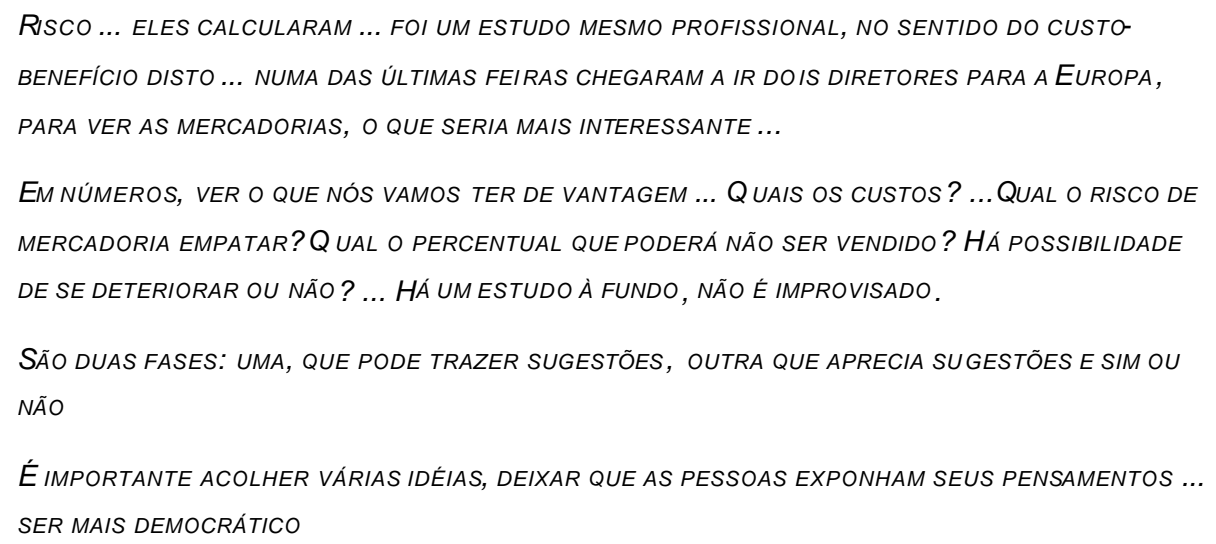

Quanto à competência contextual, é um conselho que conhece bem o centro assistencial, identifica-se com os valores e princípios organizacionais, convivendo com facilidade dentro da cultura institucional. Este "alinhamento" é (mais ou menos) garantido pelo próprio processo de seleção do membro da Associação, citado no estatuto:

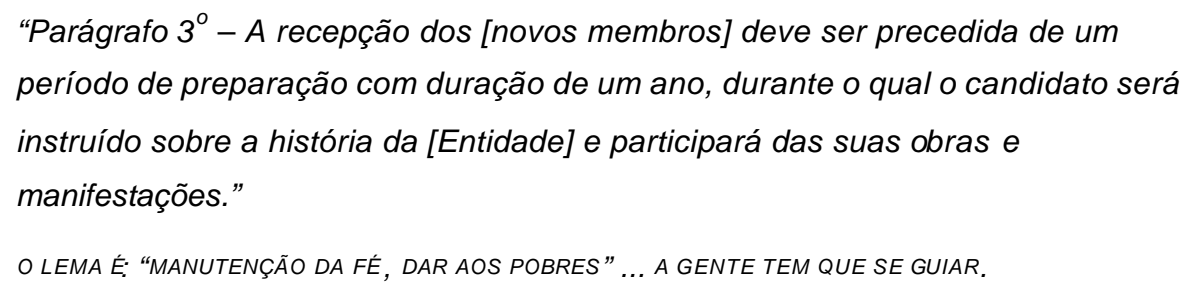

Especialmente no caso do centro de juventude, ficou clara uma preocupação da coordenadora em estabelecer uma ligação da proposta com base no "projeto inicial". Não há, entretanto, citações que indiquem a existência de reuniões para revisar ou nutrir a missão, os valores ou a filosofia da entidade.

Avaliando a competência educacional, é um conselho que aparentemente cria oportunidades para aprender a partir da prática e experiência, dispondo-se a visitar outras instituições e eventos. Porém, o aprendizado também é informal, baseado na troca entre os membros e no processo de assumir metas concretas e implementá-las.

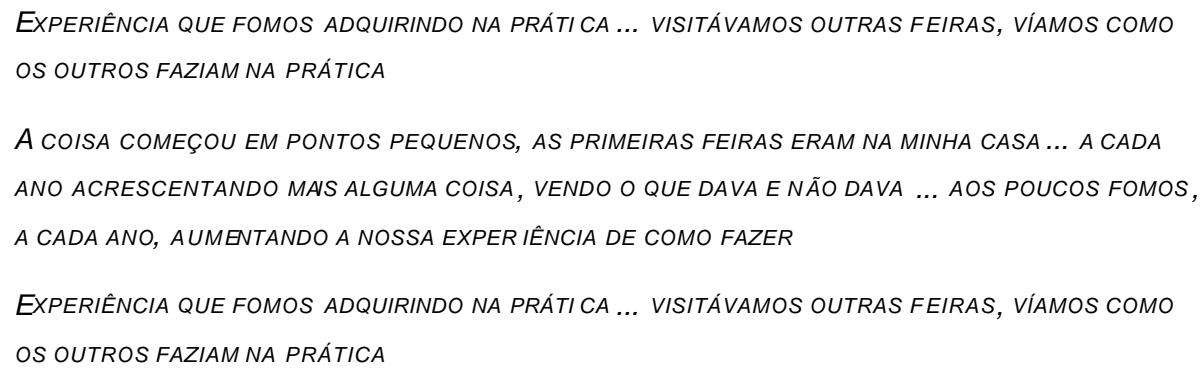


Nos aspectos da competência estratégica, uma parte da efetividade deste conselho advém da disposição em assumir riscos e responsabilidades e da ambição por construir algo maior e adequado no longo prazo. A direção executiva demanda a competência estratégica do conselho, ao definir a aprovar projetos prioritários, que é também baseada na existência de um projeto institucional bem claro.

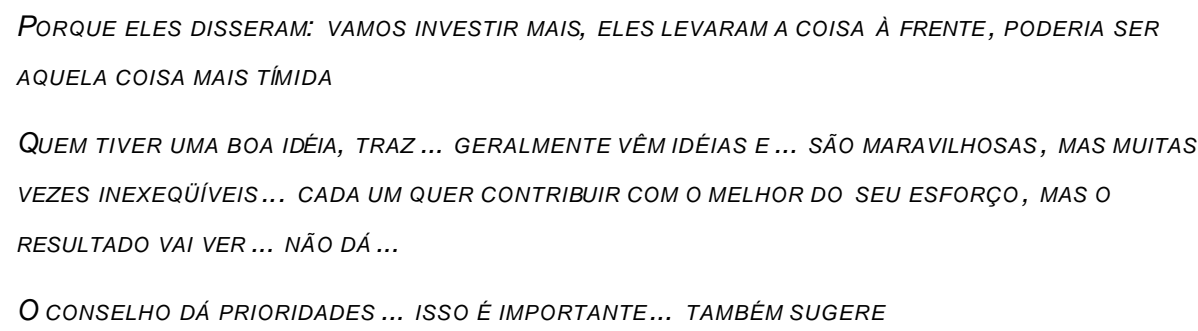

Este grupo mostra indicações de um bom grau de competência interpessoal. É um grupo aparentemente que atua em conjunto nas decisões e que sabe aproveitar o talento de cada um ao trabalhar por uma meta o conselho é capaz de estipular uma meta e comprometer-se com sua implementação. Os depoimentos demonstram haver encontros regulares dos conselheiros, bem como uma interação direta regular entre eles, num clima informal de trabalho. O processo sucessório, porém, parece ser o ponto fraco deste grupo, uma vez que as lideranças são as mesmas há 30 anos e a maioria dos conselheiros tem mais de 20 anos de casa.

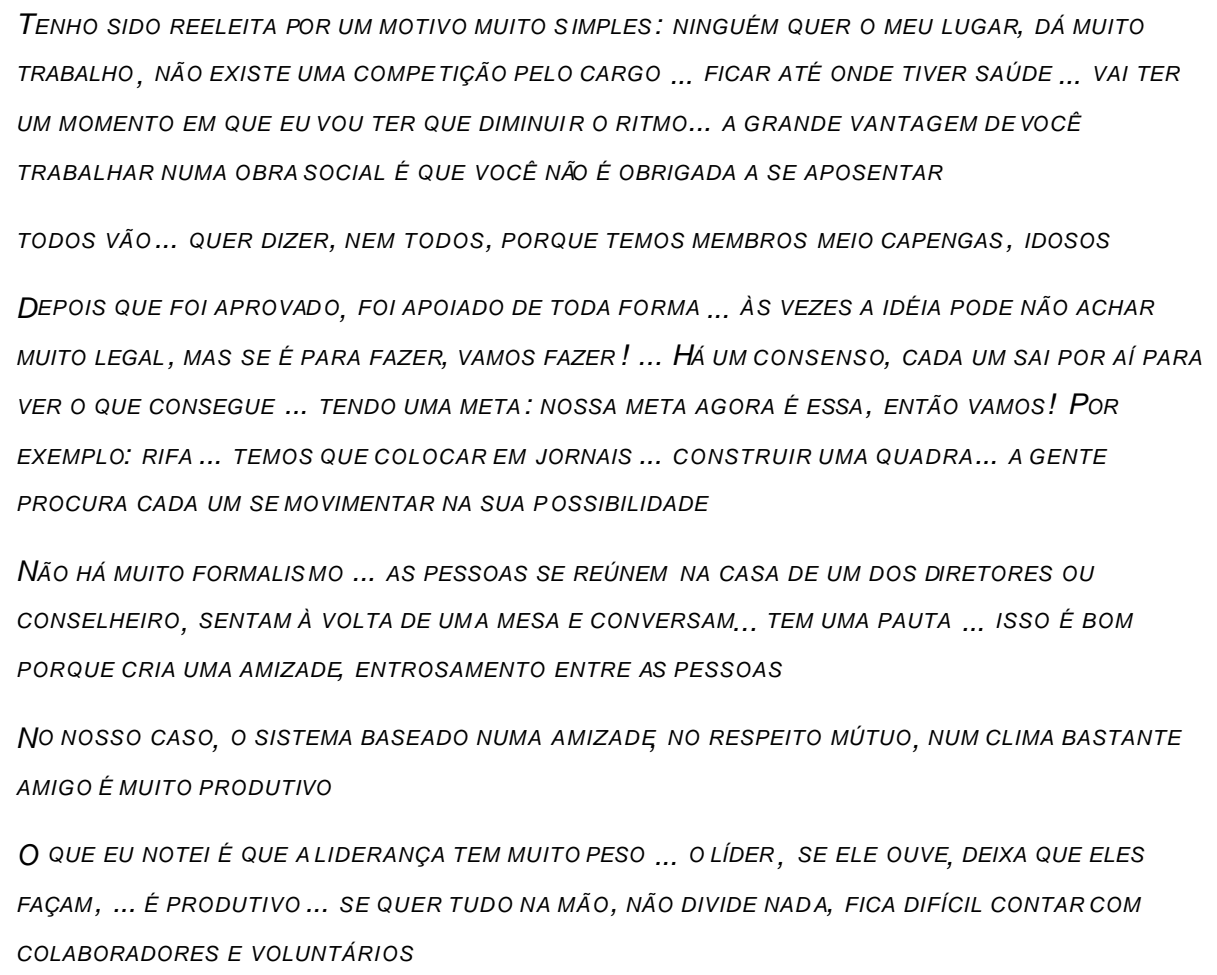

Finalmente, sob o aspecto da competência política, é um grupo forte para "abrir portas", compondo-se de pessoas bem relacionadas em setores diversos da sociedade. Os principais mecanismos de contato com os públicos da entidade são através da coordenadora e de visitas à entidade durante o dia - denotando uma preocupação pouco notável de incluir constituintes externos e representantes da equipe técnica nas decisões e consultá-los freqüentemente. 
GRANDES INVESTIMENTOS DE TRABALHO, DE PESSOAS EM FESTIVIDADES... BINGOS, RIFAS ... SOMOS

CO-RESPONSÁVEIS ... TEM QUE PRESTAR CONTAS CORRETAMENTE

\subsubsection{ENTIDADE 3}

\subsubsection{Contexto institucional}

A Entidade 3 é uma associação que foi fundada no início dos anos 40, por um grupo de ex-alunas de um colégio tradicional de São Paulo. É uma entidade grande, com quase 300 funcionários e orçamento anual beirando os $\mathrm{R} \$ 3$ milhões. Esta entidade se utiliza muito de voluntários, que mantêm uma ligação com a instituição até mesmo por gerações:

FICA UMA COISA ASSIM FAMILIAR ... NÓS TEMOS POR EXEMPLO UMA EX-PRESIDENTE QUE A MÃE TRABALHA, UMA IRMÃ DELA TRABAL HA, A FILHA TRABALHA, ISSO VAIINDO...

A OUTRA EX-PRESIDENTE, A FILHA E UM FILHO HOJE EM DIA TOMAM CONTA DE UMA PARTE NOSSA TAMBÉM ... TEM GERAÇÕES...

Segundo o estatuto, revisado em 1999, a Entidade 3 tem como objetivos:

a) favorecer e incentivar as relações de amizade entre seus associados;

b) manter obras de assistência, amparo e proteção àinfância;

c) manter obras de assistência, profissionalização, amparo e proteção àjuventude;

d) manter obras de assistência, amparo e proteção aos idosos;

e) qualquer outra atividade assistencial que for aprovada em assembléia geral dos associados.

As três pessoas entrevistadas desta instituição são todas voluntárias, sendo uma a tesoureira e as outras duas conselheiras. A tesoureira trabalha de maneira bastante livre, há bastante tempo...

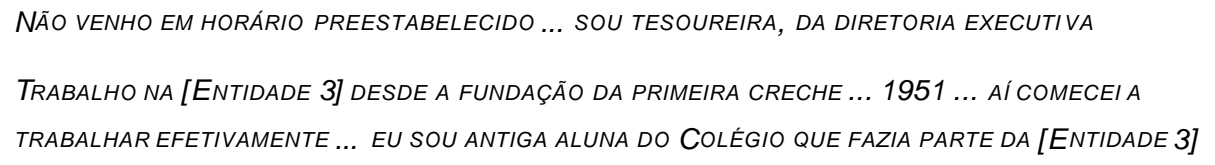

... e as conselheiras dedicam uma parte do seu tempo para produzir artigos de tricô e crochê para o bazar, praticamente fazendo parte do grupo fundador:

DESDE O DIA DA FUNDAÇÃO, HÁ 58 ANOS ATRÁS ... SOMOS ANTIGAS ALUNAS DO COLÉGIO ... COMECSAMOS A PRIMEIRACRECHE

TIVEMOS HISTÓRIA DO BRASIL EM FRANCÊS!

NÓS TEMOS FILHAS, QUE SÃO ANTIGAS TAMBÉM, E FAZEM PARTE DA [ENTIDADE 3] ... EU TAMBÉM TENHO NETOS... A MINHA MÃE TRABALHOU MUITO PARA A [ENTIDADE 3], MUITOS ANOS ... MORREU COM 77 ANOS E TRABALHOU SEM PRE PARA A [ENTIDADE 3]... 
Produzir também ... tomamos CONTA da SESSÃo de COPA E COZINHA DO BAZAR DO FIM DO ANO; ... ANO PASSADO ... FAZENDO CROCHÊZINHO, TOALHA, VENDENDO COISAS ASSIM ETC. ... CONSEGUIMOS MAIS DE SEIS MIL REAIS; ... CADA UMA TEM SEU TRABALHO MANUAL, VEZ UMA VEZ POR SEMANA AQUI E, ALÉM DISSO, LEVA TRABALHO PARA CASA ... ESTE DINHEIRO É PARA AJUDAR NO FIM DO ANO A ... DAR FÉRIAS A TODAS AS FUNCIONÁRIAS ... TEM QUE PAGAR 13O E AS FÉRIAS ... ESSA É A FUNÇÃO DO NOSSO TRABALHO

Pelos comentários acima, foi natural o processo de fazer parte da organização: a tesoureira era ex-aluna do colégio, a mãe trabalhava na entidade, suas amigas estavam lá, tinha um conhecimento pessoal da equipe e acabou sendo convidada. O processo das conselheiras foi semelhante. A realização pelo papel que ocupam, pelo que foi depreendido das entrevistas, está ligada ao sentido maior do trabalho, mas também vinculase àprópria ocupação e percepção de poder estar contribuindo para que algo socialmente relevante e útil possa ser feito:

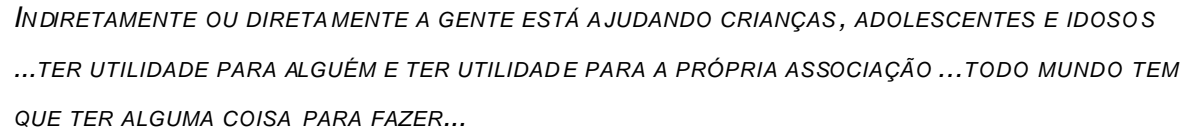

Poder saber que Nós tomamos CONTA de 2000 CRIANÇAS, AJUdAMOS A tOMAR CONTA DE 2000 CRIANÇAS ...

Tanto a tesoureira como as conselheiras mostram um desejo de continuar na organização por quanto tempo for possível, revelando uma ligação pessoal e uma percepção de que o trabalho na instituição é capaz de prover um nível de motivação e desenvolvimento suficiente para elas.

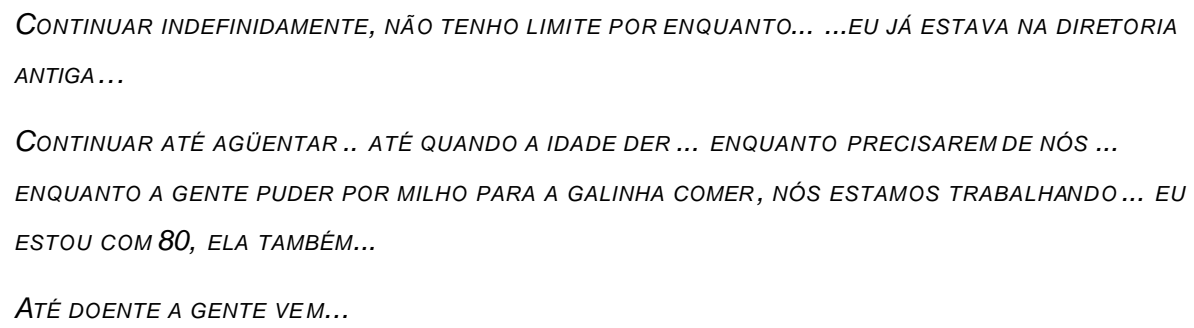

Conforme o estatuto, são órgãos dirigentes da Entidade 3:

i. Diretoria Executiva: "composta por 1 presidente, até 6 vice-presidentes, 2 tesoureiros, 2 secretários e tantos diretores quantos forem necessários", sendo que somente o presidente e os vicepresidentes são eleitos em assembléia - os demais são escolhidos pelo presidente eleito. 0 mandato é de 3 anos, sendo permitida uma reeleição. O presidente tem poderes privativos conferidos pelo estatuto para (entre outros) superintender as atividades da Associação, indicar e convidar associados para compor a diretoria, os conselhos e os departamentos, administrar o patrimônio, representar a instituição e nomear um superintendente remunerado para auxiliá-lo nas suas funções. Aos vice-presidentes compete auxiliar o presidente e planejar, organizar e dirigir a execução dos serviços administrativos da associação.

ii. Conselho Deliberativo: é composto por um corpo efetivo e um corpo titular. O efetivo é formado por até 10 membros - os ex-presidentes da entidade - e o corpo titular por 21 ou 22 membros, mais 3 ou 4 suplentes (a soma final tem que ser ímpar). Todos os conselheiros são eleitos em assembléia geral ordinária, de 3 em 3 anos, podendo ser reeleitos indefinidamente. Compete ao conselho 
deliberativo essencialmente deliberar sobre as propostas da diretoria executiva, indicar 3 nomes de candidatos a presidente da diretoria para a assembléia geral e zelar pela boa disciplina dos trabalhos da associação.

SÃO AS ANTIGAS PRESIDENTES ... É EFETIVO PORQUE JÁ FORAM E NÃO MUDA!

REÚNE-SE MAIS OU MENOS 4 VEZES POR ANO OU SEM PRE QUE HOUVER UMA NECESSIDADE

iii. Conselho Consultivo. pode ser composto por um número ilimitado de membros, tendo atualmente cerca de 130. A ele compete "comparecer e participar das reuniões e Assembléia Geral ... deliberando sobre as matérias a ele submetidas" e "exercer os direitos e deveres de associado de forma mais efetiva, colab orando e participando das atividades da [Entidade 3]".

O conselho fiscal (5 membros) e a diretoria de departamentos são órgãos colaboradores dos dirigentes da administração e o estatuto ainda explicita as competências do superintendente: "determinar e exeautar todas as medidas para a administração eficiente" da associação, sob orientação da diretoria executiva.

A tesoureira mantém contato mais indireto, pontual e formal com o conselho deliberativo, interagindo mais com a diretoria:

O CONTATO COM O CONSELHO ... MAIS NAS REUNIÕES, QUANDO O CONSELHO É CONVOCADO ... CONTATO MUITO CORDIAL

Segundo ela, as decisões são tomadas...

...EM TODA PARTE DA DIRETORIA...

...(REUNIÕES) DA EXECUTIVA, DE 15 EM 15 DIAS...

...A PARTE FINANCEIRA, SEMPRE JUNTO COM A PRESIDENTE... PELO MENOS TRÊS VEZES POR SEMANA..

...A GENTE NÃO TRABALHA INDIVIDUALMENTE...

A tesoureira não é, portanto, a principal liderança executiva da Entidade 3.

\subsubsection{O Papel do Conselho nos Incidentes Críticos}

No caso da Entidade 3, foram relatados 6 incidentes, sendo os principais referentes às seguintes situações:

- Venda de uma casa recebida em doação. O conselho foi consultado a respeito da venda da casa.

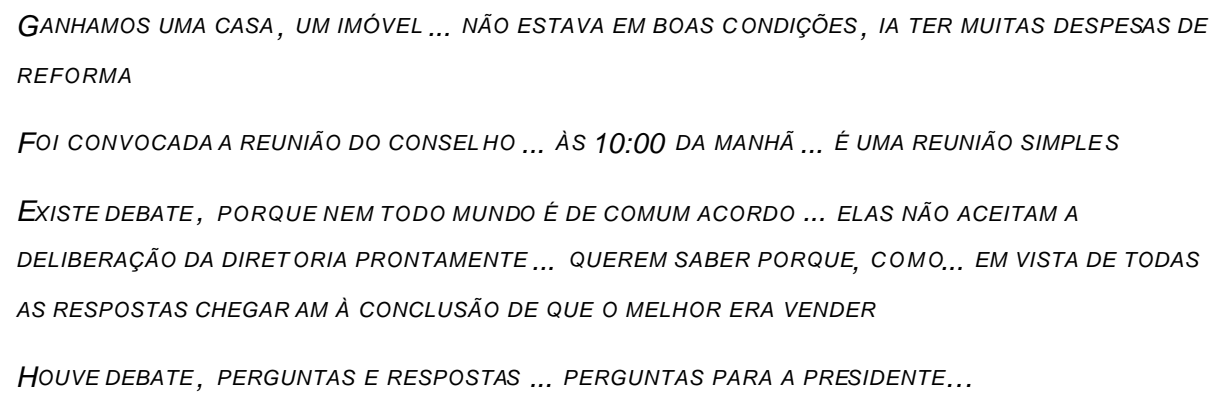

- Uma fundação ofereceu uma creche e um prédio para a Entidade 3 dirigir. A diretoria levou o convite para o conselho decidir. 
A FAMÍLIA NÃO PODIA MAIS MANTER, FOI PARAR NO CURADOR ... A FAMÍLIA OFERECEU PARA A

[ENTIDADE 3] ASSUMIR ... A FUNDAÇÃO JÁ TINHA UMA CRECHE ... QUE NÃO PODE SER EXTINGUIDA, TEM QUE CONTINUAR

ESTA FUNDAÇÃO TEM UM PRÉDIO MUITO GRANDE ... A CRECHE OCUPA O AND AR TÉRREO ... A OUTRA PARTE PODE SER UTILIZADA PARA O QUE QUISER

Houve DEBATES EM QUE UMA PARTE ACHAVA QUE SERIA MUITO ONEROSO PARA A[ENTIDADE 3], FORAM LEVADAS FOTOS DO LOCAL, FORAM DISCUTIDAS TODAS AS POSSIBILIDADES DO QUE FAZER NA OUTRA PARTE QUE NÃO É CRECHE, DE PODER ALUGAR PARA A MANUTENÇÃO DA PRÓPRIA CRECHE, OU FAZER OUTROS CURSOS, A PARTE SOCIAL MAIS EFETIVAMENTE, FAZER UM CJ LÁ, QUE NÃO TEM... PELOS DEBATES, DISCUSSÕES, PERGUNTAS, RESPOSTAS, O CONSELHO DELIBERATIVO ACABOU CONCORDANDO EM QUE A[ENTIDADE 3] ASSUMISSE A FUNDAÇÃO

FoI UMA REUNIÃo CONVO CADA TAMBÉM... ACHO QUE NESTA EU ESTAVA ... DUROU UMA HORA E MEIA TALVEZ

FOI FEITA UMA GRANDE REFORMA LÁ, PARA ADEQUAR BEM A CRECHE ... ISSO COMEÇOU NO COMEÇO DE 1999, NÓS SÓ ASSUMIMOS EM NOVEMBRO ... HOJE ESTÁ NOS MOLDES DA [ENTIDADE 3],

REFORMADA ... AINDA EM ESTUDOS O RESTO DO LOCAL

FOMOS LÁ FAZER VISITA... APROVAMOS E FOMOS CONHECER

- Reunião para aprovar o conselho fiscal. A diretoria sugeriu uma lista de nomes e levou ao conselho deliberativo para aprovação.

O CONSELHO FISCAL FOI CRIADO ESSE ANO ... OS NOMES FORAM ESCOLHIDOS PELA PRESIDENTEE ACEITOS PELA DIRETORIA

ELA APRESENTOU PARA O CONSELHO DELIBERATI VO PARA APROVAÇÃO ... FOI ACEITO, ERAM NOMES CONHECIDOS, DE VALOR, DE CONHECIMENTO DO CONSELHO TODO

FOI UMA REUNIÃO SIMPLES, NÃO HOUVE DISCUSSÃO, APROVADO POR UNANIMDADE, FOI RÁPIDO

- Donativo de um terreno de 12 mil metros quadrados. O conselho foi convocado para aprovar o plano de construção no terreno.

O CONSELHO ENTROU NO MEIO PORQUE NÓS PREFERIAMOS CONSTRUIR PED AÇOS ISOLADOS, MAS DEPOIS ACABAMOS CONCORDANDO COM A DIRETORIA QUE ERA PREFERÍVEL CONSTRUIR TUDO JUNTO: A CASA NOVA DOS IDOSOS, A CRECHE DAS CRIANÇASE O CJ ...

É SEMPRE A PRESIDENTE (QUE APRESENTA O CASO PARA O CONSELHO) ... ELA CONTOU QUE HAVÍAMOS RECEBIDO ESTE DONATIVO E QUE ELA PRETENDIA CONSTRUIR E QUE NÓS PRECISÁVAMOS CHAMAR ARQUITETO E ENGENHEIRO PARA FAZER TODO O PLANEJAMENTO

Fol aPRovado E FOI CONSTRUIDO ... FICAMOS COM UMA DíVIDA GRANDE ... PARA FAZER O emprÉstimo na CaIXa tinHA QUE SER o PLANO COMPLETO ... ENTÃo FOI CONSTRUÍDO TUdO JUNTO

(A PERGUNTA DELA PARA OCONSELHO ERA) VOCÊS CONCORDAM? ... O CONSELHO RESPONDEU: CONCORDAMOS!

- Caminhões carregados de material apreendido na alfândega. O conselho contribuiu na divulgação do programa de vendas do material apreendido, para arrecadar dinheiro para construir uma creche nova. 
RECEBEMOS DOIS CAMINH ÕES DE MATERIAL APREENDIDO NA ALFÂNDEGA ... VENDEMOS TUDO AQUI DENTRO ... COMPRAMOS UM TERRENO E CONSTRUIMOS UMA CRECHE INTEIRA ... COMPRAMOS UM TERRENO EM FRENTE E CONSTRUÍMOS UM CJ

O CONSELHO FICOU ENCANTADO COM A HISTÓRIA, FEZ UMA PROPAGANDA ENORME PARA TRAZER AS PESSOAS PARA COMPRAR

HaVIa um dePUTAdo que FAZIA PARA NÓS, hOJE EM DIA NÃO dÁ MAIS ... É UMA PENA PORQUE Nós FAZÍAMOS CRECHE PELA METADE DO PREÇO DAPREFEITURA ...

De forma mais ou menos regular são trazidas à mesa do conselho questões para aprovação; o conselho para isso atua em conjunto, numa reunião. Aparentemente o conselho costuma fazer um bom número de perguntas, baseando seus comentários na sua experiência pessoal e "bom senso". O conselho mantém -se disponível e tem um papel decisório-aprovador, existindo um certo plano implícito de que uma prioridade é atender o maior número possível de crianças, jovens e idosos.

Pelos comentários da tesoureira, as conselheiras são ativas, próximas à organização, vindo freqüentemente à instituição, embora com periodicidade variável e aleatória; nestas vindas as conselheiras concentram-se em atividades operacionais em setores específicos.

A atuação do conselho como grupo se dá somente nas reuniões. Mesmo o processo eleitoral é, aparentemente, fragmentado. A convocação do conselho é baseada em questões específicas, presentes, que têm certo risco, especialmente financeiro. Assim, o conselho é, de certa maneira, responsivo, isto é, responde às demandas da diretoria. $\mathrm{O}$ caso da casa mostra que o conselho preocupa-se em assegurar que uma decisão de porte grande seja tomada com prudência, procurando assegurar que havia condições para tal empreendimento ser iniciado. $O$ conselho fez perguntas, reuniu-se quando convocado - atendeu os apelos da presidente - e cuidou para que fosse aproveitada uma oportunidade.

É nas reuniões que são fornecidas as informações necessárias para uma decisão, acompanhadas normalmente de uma análise de possíveis cenários futuros e do parecer da presidente e da diretoria. A diretoria parece preocupar-se em responder com cuidado às perguntas do conselho, mas aparentemente o que espera é a aprovação das propostas. Pela forma como foi apresentado, parece que a presidente cuida para que as decisões sejam trazidas praticamente prontas. Esta é uma das razões para o conselho gastar tão pouco tempo em reuniões.

O CONSELHO NÃO DIZ AMÉM, ELE QUESTIONA OS PRÓS, OS CONTRAS...

A geNTE NÃo faZ MUITA PERGUNTA, PORQUE JÁ VEM TUdO MASTIGADO, CERTINHO ... A PRESIDENTE QUE RESOLVE ... NÓS TEMOS QUE APROVAR

TEM SEMPRE UMA QUE PERGUNTA ALGUMA COISA FORA DO COMUM, MAS EM GERAL É UMA UNANIMIDADE MUITO GRANDE ... QUANDO SE ESTÁ TRABALHANDO JUNTO HÁ MUITOS ANOS AS CABEÇAS FICAM MAIS OU MENOS PARECIDAS, IGUAIS

É SEMPRE A PRESIDENTE (QUE APRESENTA O CASO PARA O CONSELHO) ...

QUANDO A DIRETORIA TEM NECESSIDADE DE OUVIR UM PALPITE, DE NOSSO VOTO ... SOMOS CONVOCADAS PARA DIZER SE ESTAMOS DE ACORDO

A GENTE PERCEBE AS INF ORMAÇÕES DE COMO ESTÁ ANDANDO TUDO E TAMBÉM DÁ OS PALPITES 
A GENTE SE REÚNE UMA A DUAS VEZES POR ANO SÓ QUANDO HÁ NECESSIDADE ... SÓ QUANDO TEM COISA PARA DELIBERAR MESMO ... POR EXEMPLO: FAZER MUDANÇA NOS ESTATUTOS

QuANDO É CONVOCADO O CONSELHO DELIBERATIVO, É ESPECÍFICO... PARA COISAS ESPECÍFICAS ... ELE É CONVOCADO A MAIORIA DAS VEZES

A gente que dá a PALAVRA FINAL PARA A PRESIDENTE E A DIRETORIA TODA ... POR EXEMPLO ... OS NOMES TODOS PARA O CONSELHO FISCAL FORAM APROVADOS POR UNANIMIDADE...

Aparentemente, a figura do presidente do conselho é meramente formal, com praticamente nenhuma influência na operação e no desempenho do grupo de conselheiras:

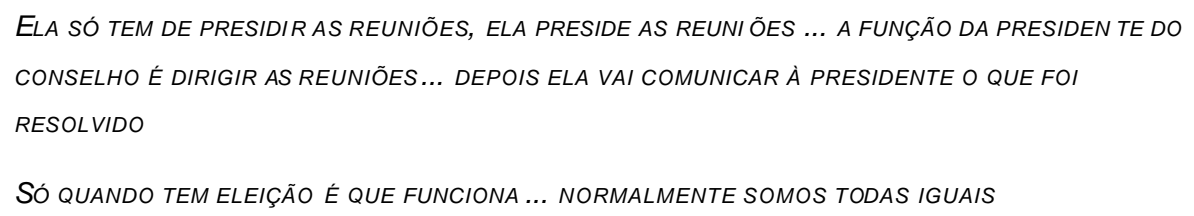

Considerando a entidade toda, o conselho é importante pelo apoio que representa para a presidente e a diretoria e por assegurar, indiretamente, que a instituição tome decisões do tamanho que pode assumir; o conselho parece ter importância também como guardião ou símbolo das diretrizes gerais dadas pelas tradições institucionais.

Operacionalmente, a presença do conselho, ou melhor, de voluntárias conselheiras, é importante para que atividades específicas sejam realizadas, tendo impacto tanto financeiro, como de reforço das tradições da entidade.

O CONSELHO APOIA A DIRETORIA...

ELES QUERIAM SABER COMO ESSA FUNDAÇÃO VIRIA DE ENCONTRO COM A [ENTIDADE 3] ... SE A

[ENTIDADE 3] TERIA CONDIÇÕES DE A SSUMIR, CONDIÇÕES INCLUSIVE FINANCEIRAS ... ESSA É A PARTE QUE MAIS PREOCUPA ...

O LOCAL, SE LÁ TEM CHANCES DE MUITAS COISAS PARA O FUTURO ... PARA O FUTURO A GENTE VÊ A POSSIBILIDADEDE ATENDER MAIS JOVENS, TIRAR MAIS CRIANÇAS DA RUA ...

DÁ PARA A PRESIDENTE MUITA SEGURANÇA, PORQUE SE O CONSELHO APROVA É PORQUE ESTÃO CIENTES DO QUE ESTÃO FAZENDO, DA CAPACIDADE DA SUPERINTENDENTE

É UM APOIO TOTAL ÀS DECISÕES DA DIRETORIA EXECUTIVA ... ESSE APOIO É TUDO ... A DIRETORIA SABE QUE PODE CONTAR COM O CONSELHO, A DIRETORIA CONTA COM O CONSELHO

ELE É IMPORTANTE PARA DAR O APOIO ... ELE NÃO DELIBERA SOZINHO E A DIRETORIA NÃO DELIBERA SOZINHA, É UM CONJUNTO

A FUNÇÃO DO CONSELHO É ESSA MESMO: APOIAR A DIRETORIA, APOIAR NOS EVENTOS

ELE DIRECIONA, MAS NÃO PROPÕE COISAS MUITO PARA O FUTURO

NÃO DÁ O PASSO MAIOR QUE A PERNA

ANTECIPAR PROPRIAMENTE, NÃO ... ELE ESTÁ À PAR DOS PROBLEMAS ... ELAS NÃO SE REÚNEM PARA DISCUTIR ESSAS COISAS, MAS APRESENTAM ESTAS TENDÊNCIAS

DE 3 ANOS PARA CÁ NÃO FIZEMOS TANTAS COISAS, JÁ ESTÁ TUDO PRONTO 
Na Entidade 3 há uma distinção bastante clara, formal e prática, entre conselho e diretoria e ainda superintendência. O conselho mantém-se à distância, assumindo um papel de aprovador dos planos, propostas e trabalhos da diretoria. Os conselheiros que se envolvem no dia-a-dia o fazem como voluntários comuns, não como conselheiros. A diretoria, aparentemente, é que governa a Entidade 3, dando suporte e diretrizes à superintendente, que atua como diretora executiva. Nesta entidade, infelizmente, não foi possível conversar nem com a presidente da diretoria, nem com a superintendente, o que possivelmente agregaria informações valiosas àpesquisa. O conceito de Houle, citado anteriormen te...

Um grupo organizado de pessoas com a autoridade coletiva para controlar e fomentar uma instituição que é normalmente administrada por um gestor qualificado e uma equipe executiva.

... pode ser muito bem aplicado à diretoria, deixando dúvidas se realmente o papel de conselho é exercido pela diretoria ou pelo conselho.

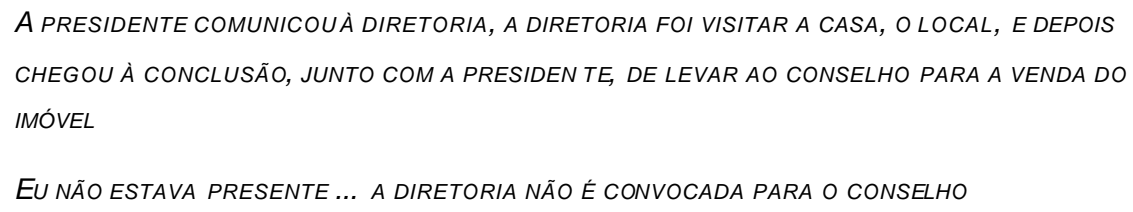

A presidente ocupa o papel de principal liderança institucional e o conselho a tem como referência para seus trabalhos. Há, aparentemente, alguma dependência do conselho para com a presidente, por todos os comentários feitos até aqui; porém, a presidente utiliza-se do conselho apenas nos casos em que existe uma dimensão simbólica e um risco financeiro grande a ser assumido. Com o trabalho simbólico, reforça-se a cultura institucional, nutre-se a moti vação das conselheiras a continuar cuidando de tarefas específicas e reforçase o "senso de comunidade" que existe em torno da entidade.

Finalmente, parece que na Entidade 3 um conselho que "cria problemas" é visto como pouco efetivo - um conselho efetivo questiona, porém não emperra, dando alto nível de autonomia para a diretoria. $O$ compromisso do conselho com a causa da entidade é considerado um item que tem influência sobre a efetividade do conselho, bem como o seu grau de coesão interna. Neste contexto,é difícil atribuir resultados diretamente ao conselho.

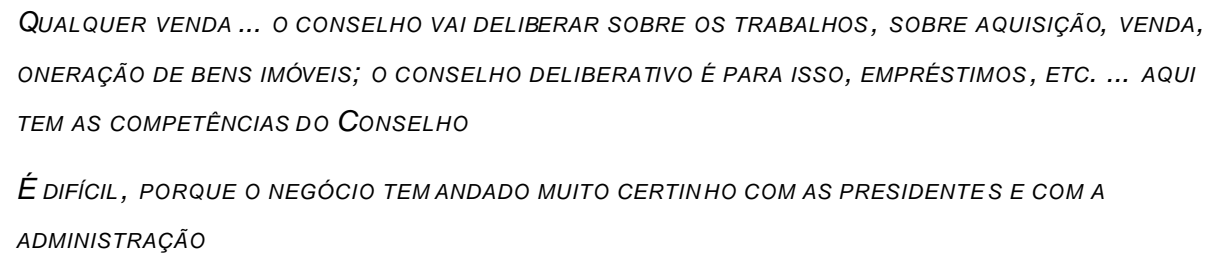

\subsubsection{Competências desenvolvidasas}

Como em qualquer entidade, pode-se notar comportamentos que denotam um bom nível de competência analítica e também comportamentos que denotam que bastante há para ser desenvolvido. É positiva a existência de uma prioridade comum (ampliar o atendimento) como referência nos processos de análise das situações apresentadas ao conselho. E nos casos descritos houve várias citações de perguntas feitas pelo conselho, indicando que o conselho faz perguntas para ampliar sua perspectiva na análise dos problemas. Porém, duas características indicam que isso pode não representar um alto grau de competência analítica: 
primeiro, o conselho parece fazer perguntas porque recebe informações na hora de decidir - ele faz perguntas para informar-se; segundo, porque nem sempre a qualidade das perguntas é boa. A seguinte citação exemplifica bem o tipo de questões levadas ao conselho:

VOCÊS CONCORDAM?

Este tipo de questão é relativamente fechada e restringe a busca de alternativas melhores. Ainda, boa parte das perguntas eram mais preocupações financeiras. No incidente do plano de construção aparentemente poderiam ser cogitadas mais alternativas e conseqüências, conforme mostram as afirmações a seguir. Por último, é extremamente preocupante a existência de tão poucas diferenças nas reuniões do conselho, indicando uma possível dificuldade do grupo em trabalhar com divergências e mesmo um esforço em evitar que elas surjam.

O CONSELHO NÃO DIZ AMÉM, ELE QUESTIONA OS PRÓS, OS CONTRAS...

A INTENÇÃO É DE AUMENTAR, FAZER O CJ, FAZER OUTROS CENTROS LÁ ... FOI ACERTADO NESSE SENTIDO DE ABRIR MAIS AQUELE LOCAL, A REGIÃO DA ZONA LESTE TEM MUITA PROCURA ...

O LOCAL, SE LÁ TEM CHANCES DE MUITAS COISAS PARA OFUTURO ... PARA O FUTURO A GENTE VÊ A POSSIBILIDADE DE ATENDER MAIS JOVENS, TIRAR MAIS CRIANÇAS DA RUA

ELES QUERIAM SABER COMO ESSA FUNDAÇÃO VIRIA DE ENCONTRO COM A [ENTIDADE 3] ... SE A

[ENTIDADE 3] TERIA CONDIÇÕES DE ASSUMIR, CONDIÇÕES INCLUSIVE FINANCEIRAS ... ESSA É A PARTE QUE MAIS PREOCUPA ...

FICARAM MUITO ENTUSIASMADOS, TODO MUNDO ENTUSIASMOU DEMAIS

A GENTE NÃO PENSAVA QUE PUDESSE TER DIFICULDADES FINANCEIRAS E MUDANÇA DE GOVERNO

LOGO DE CARA NÓS JÁ SOUBEMOS QUE ÍAMOS GANHAR TODO O CIMENTO PARA A CONSTRUÇÃO

TIVEMOS MUITAS REGALIAS

Avaliando-se a competência contextual do conselho da Entidade 3, pode-se dizer que ele apresenta um grande entendimento das tradições, da história e dos valores institucionais, vive nciando e reforçando a cultura organizacional. Há por trás disso um forte vínculo pessoal, muitas vezes de parentesco, que atua como um importante mecanismo de transmissão destas tradições. Também ao atuar em coisas práticas e específicas o conselho toma contato com a realidade do dia-a-dia e pode transmitir um pouco desta cultura.

O que não aparece nos depoimentos sobre a Entidade 3 são iniciativas para renovar algo desta cultura, não se percebem tensões, nem tampouco críticas, denotando uma grande ênfase com estabilidade e manutenção.

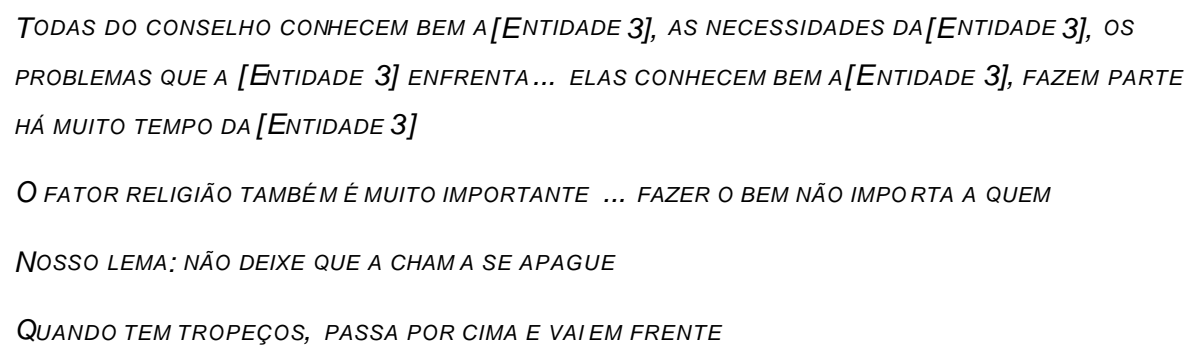

Com as informações disponíveis fica difícil concluir algo a respeito da competência educacional do consel ho da Entidade 3. O que se pode dizer é o que ele não faz: ele não pára para avaliar-se e verificar que erros 
porventura possa ter cometido, e nem mesmo preocupase com a orientação a novos membros. Entretanto, as conselheiras mostram humildade ao reavaliar suas posições em virtude das conseqüências de uma decisão que aprovaram, no caso do plano de construção.

Do ponto de vista da competência estratégica parece um conselho pouco ativo, pois concentra-se em questões do tipo "aqui e agora", utilizando-se basicamente de "bom senso". Há, porém, sempre preocupação com a segurança da instituição, em ouvir as propostas e visões da diretoria, uma prudência valiosa em "não dar o passo maior do que a perna" e uma prioridade implícita de ampliar o atendimento sempre que possível. Este conselho, ao contrário de outros, tem mais um caráter consolidador e de manutenção e quase nada de dinamizador - pode-se dizer até que o conselho da [Entidade 3] está mais voltado para o passado e para o presente do que para o futuro, atuando mais em questões específicas do que em questões globais. Ele trabalha junto somente quando convocado e tem uma função mais de apoio do que de governo. É muito mais um guardião do que um líder, sem deixar de ter um caráter institucional forte.

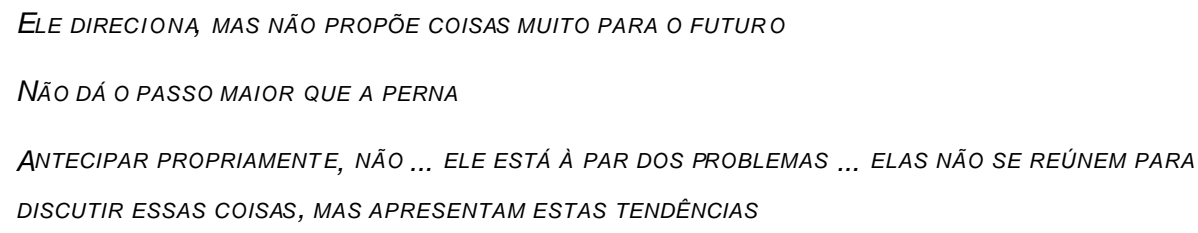

Quanto à competência interpessoal fica evidente que as conselheiras todas se conhecem e mantêm um bom relacionamento. As pessoas da diretoria e do conselho parecem fazer parte de um mesmo tipo de grupamento social, o que facilita as relações e a aceitação mútua, não sendo estranhas ente si. A maioria está há décadas trabalhando na organização e teve uma vivência e formação básica comum. Além disso, há um clima "familiar", pois trabalhar na organização é uma coisa transmitida entre gerações. Fica uma dúvida se ainda está presente o grupo fundador. Os depoimentos indicam que sim, mas num papel de guardião dos valores e da razão de ser da instituição.

Não é um conselho que assume metas para si, nem tampouco se ocupa formalmente com o cultivo de novas lideranças, aparentemente. Pelo tempo que todas pretendem ficar na associação pode-se inferir que o processo de renovação é informal e aleatório, vinculado ao processo eleitoral.

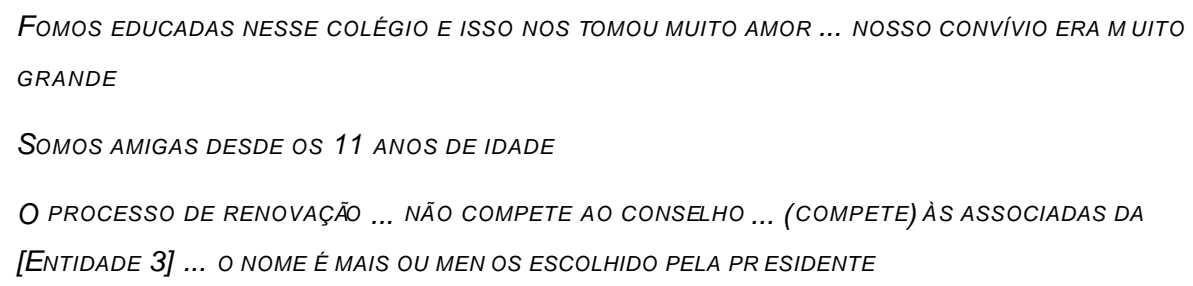

Do ponto de vista da competência política, há poucos indícios para análise. Parece que a atuação do conselho se dá mais para mobilizar contatos para captar recursos financeiros e para trazer novos voluntários para dentro. Pode-se afirmar, entretanto, que o conselho respeita o papel de outras instâncias no governo da instituição, reconhecendo, por exemplo, a autoridade da diretoria sobre vários assuntos. Ainda, as conselheiras pela sua atuação em atividades específicas mantêm um contato regular e intenso, pelo que parece, tanto com a equipe técnica e executiva, quanto com o público beneficiado pela entidade. 
Por outro lado, considerando que a comunidade de ex-alunas do colégio é uma das principais constituintes da entidade, o conselho parece cuidar para que estas relações se mantenham harmônicas e vivas, mesmo que pelo esforço individual dos seus membros.

\subsubsection{ENTIDADE 2}

\subsubsection{Contexto institucional}

Segundo o estatuto, a Entidade 2 foi fundada sob os auspícios de um centro espírita, que é a sua principal entidade mantenedora. São finalidades da organização:

a) Dar prosseguimento ao trabalho assistencial e educacional, reerguimento e conscientização das famílias carentes de subsistência, em funcionamento desde 1976, no Centro Espírita;

b) Prestar assistência médica, odontológica e farmacêutica;

c) Fornecer alimentos, roupas, agasalhos e utensílios em geral;

d) Dar atendimento a crianças com carência sócio-econômica comprovada, em regime de semiinternato, através de creches.

Fol Fundada eM 1986 como um dePARTAMENTO do CENTRO EsPÍRITA ... EM 1992 TEVE Que DESMEMBRAR-SE POR FORÇA DE LEI ... HAVIA UMA RESOLUÇÃO ... QUE IMPEDIA QUE ENTIDADES RELIGIOSAS RECEBESSEM SUBVENÇÕES ... ESSA RESOLUÇÃO FOI DERRUBADA 6 MESES DEPOIS, MAS JUSTAMENTE NESTE PERÍODO DE 6 MESES NÓS ESTÁVAMOS SOLICITANDO OS NOSSOS REGISTROS DE UTILIDADE PÚBLICA FEDERAL ... PARA CONSEGUIRMOS OS REGISTROS TIVEMOS QUE DESMEMBRAR ... A [ENTIDADE 2] É HOJE UMA ENTIDADE INDEPENDENTE, COM PERSONALIDADE JURÍDICA PRÓPRIA .

A PROPOSTA DA INSTITUI ÇÃO É A EDUCAÇÃO ... MISSÃO É EDUCAR A CRIANÇA E O ADOLESCENTE CARENTE ... E QUE COM ISSO A GENTE POSSA ESTAR CONTRIBUINDO PARA A CONSTRUÇÃO DE UM MUNDO MELHOR

HOJE É UMA INSTITUIÇÃO COORDENADA POR ORIENTADOR PEDAGÓGICO, A GRANDE MAIORIA DOS MONITORES TEM MAGISTÉRIO, NÓS TEMOS UM ASSISTENTE SOCIAL, ENFIM, TEMOS QUADRO TÉCNICO, NÃO É FEITA UMA COISA DE BOA VONTADE APENAS ... UMA BOA VONTADE AMPARADA NA TÉCNICA, NO CONHECIMENTO ... HOJE ESTÁ TODO MUNDO SE RECICLANDO NUM CURSO NUMA FACULDADE A FAMILIA É OBRIGADA A COMPARECER ÀS REUNIÕES, SÃO VISITADAS PELA EQUIPE DE ASSISTÊNCIA SOCIAL E VOLUNTÁRIOS ... A CRIANÇA SÓ PERMANECE NA INSTITUIÇÃO SE OS PAIS TRABALHAREM ... AFINAL, A RESPONSABILIDADE COM A CRIANÇA NÃO É NOSSA, NÓS SOMOS PARCEIROS

De acordo com o estatuto, a Entidade 2 tem os seguintes órgãos na administração:

a) Assembléia geral: é o órgão soberano, constituído pelos sócios. Reúne-se ordinariamente duas vezes por ano, segundo o estatuto.

b) Conselho diretor: é o órgão supervisor da administração, constituído por 30 membros, todos sócios, dos quais 5 suplentes, eleitos pela Assembléia pelo prazo de 3 anos.

TEMOS EM SUA COMPOSIÇÃO OS MAIS DIVERSOS ELEMENTOS: DESDE MÉDICOS, ADVOGADOS, DENTISTAS ATÉ A CRIATURA QUE É PRENDAS DOMÉSTICAS... É BEM VARIADO ... A MÉDIA DE IDADE É DOS 30 a 45 ANOS ... 95\% (MORA EM SANTO ANDRÉ) 
c) Diretoria executiva: é composta por 7 membros, eleitos pelo conselho diretor entre seus membros, para um mandato de 3 anos, não devendo haver mais de uma reeleição consecutiva no mesmo cargo. Compete à diretoria executiva: dirigir as atividades da entidade, elaborar um programa e o orçamento anual de atividades, autorizar a admissão/dispensa de empregados e movimentar as contas bancárias. Pelo estatuto, reúne-se ordinariamente uma vez por bimestre.

d) Conselho fiscal: constituído por 3 membros, eleitos pela Assembléia geral, com mandato de 3 anos. Segundo o conselheiro:

SOU CONSELHEIRO E FAÇ O PARTE DA DIRETORIA EXECUTIVA

TEM REUNIÕES PERIÓDIC AS, ESTATUTÁRIAS... ALÉM DISSO TEM AS REUNIÕES QUE SÃO CONVOCADAS POR QUALQUER MEMBRO

EU ACABEI SINTONIZADO COM OS OBJETIVOS DESTA PROPOSTA EM 1986 ... ACABEI ME IDENTIFICANDO COM OS OBJETIVOS DA INSTITUIÇÃO ... NAQUELA OCASIÃO A INSTITUIÇÃO ESTAVA AINDA RECÉMFORMADA ... ESTOU COM TRABALHO VOLUNTÁRIO DESDE AQUELA ÉPOCA

EU SOU EMPRESÁRIO, SOU COMERCIANTE, ENTÃO TRAGO A MINHA VIVÊNCIA PROFISSIONAL PARA A INSTITUIÇÃO ... 40 ANOS ... EU SOU ADMINISTRADOR DE EMPRESAS ... DEDICAÇÃO... MENOS DO QUE 3 DIAS POR SEMANA

NA VERDADE, AQUI A GENTE FAZ DE TUDO ... O VOLUNTÁRIO AQUI FAZ DESDE UM RELATÓRIO ADMINISTRATIVO ... MINHA VIVÊNCIA É ADMNISTRATIVA ... COMO CARREGO CADEIRA, CARREGO MESA, CONSTRUO PAREDE ... TUDO QUE A GENTE TIVER CONDIÇÕES DE FAZER, A GENTE FAZ ... COMO VOLUNTÁRIO, NÃO EXISTE UM TRABAL HO ESPECÍFICO

COMO ... FAÇO PARTE DA DIRETORIA EXECUTIVA, A GENTE TEM TRABALHADO TAMBÉM NA ÁREA ADMINISTRATIVA, BUSCANDO ... IDEALIZAR MEIOS PARAQUE A GENTE POSSA BUSCAR OS RECURSOS NECESSÁRIOS PARA MANTER A INSTITUIÇÃO ... FAZER COM QUE ESSES RECURSOS SEJAM MELHOR APROVEITADOS ... TENHAM MELHOR RENTABILIDADE

Nesta entidade ainda estão presentes e ativos os fundadores, como pode se denotar pelos comentários da liderança executiva:

TEMOS UMA ASSEMBLÉIA GERAL, UM CONSELHO DIRETOR, UM CONSELHO FISCAL E DIRETORIA EXECUTIVA ... E TEM COMISSÕES

O QUE TEMOS FEITO NÓS: APROVEITADO O PESSOAL DO CONSELHO PARA COLOCÁ-LOS COMO RESPONSÁVEIS NAS NOSSAS COMISSÕES ... NÓS TEMOS A COMISSÃO DE EVENTOS, A COMISSÃO DE ARRECADAÇÃO, ...

ALGUNS NOMES DO CONSELHO ... TÊM REUNIÕES ATÉ MAIS DO QUE A DIRETORIA EXECUTIVA POR CAUSA DAS COMISSÕES ... HOJE, POR EXEMPLO, TEM UMA REUNIÃO DO PESSOAL DA ARRECADAÇÃO; AMANHÃ TEM UMA REUNIÃO DO PESSOAL DE EVENTOS ... CADA UM VAI FAZENDO A REUNIÃO E SE COMUNICANDO

EU SOU VICE PRESIDENTE DA DIRETORIA EXECUTIVA, MAS OBRIGATORIAMENTE FAÇO PARTE DO CONSELHO E ASSEMBLÉIA GERAL ... A ASSEMBLÉIA GERAL TIRA O CONSELHO, O CONSELHO TIRA A DIRETORIA...

SOU (FUNDADORA) ... UM SONHO, O COMPROMISSO QUE VOCÊ TEM DESDE QUE VOCE PARTICIPE DE UMA RELIGIÃO QUE TE DÁ RESPONSABILIDADE ... AQUELA QUE TE CONSCIENTIZA DO PORQUE VOCÊ 
ESTÁ AQUI, O QUE VOCÊ DEVE FAZER ... TOTALMEN TE VOLUNTÁRIA ... ASSISTENTE DE DIRETOR APOSENTADA ... 66 ANOS ... TRABALHEI 31 ANOS NO ESTADO E 21 ANOS NO SESI

ÉRAMOS UM GRUPO dE ESTUdIOSOS, FUNDAMOS O CENTRO ESPÍRITA, O GRUPO FOI CRESCENDO E Aí SENTIMOS O DESEJO DE AMPLIAR A NOSSA ATIVIDADE DE SOLIDARIEDADE QUE ERA FEITA COM A DISTRIBUIÇÃO DE SACOLAS, COM ATENDIMENTO ODONTOLÓGICO, ATENDIMENTO MÉDICO, MAS SEM UM COMPROMISSO GRANDE COMO É UMA CRECHE, QUE É UMA INSTITUIÇÃO EDUCACIONAL ...

Nós teMOS AS REUNIÕES PELO MENOS UMA VEZ A CADA MÊS, UMA VEZ A CADA MÊS E POUCO ... A DIRETORIA

(O CONSELHO) SE REÚNE ... ESTATUTARIAMENTE DEVERIA UMA VEZ SER A CADA 2 MESES, MAS ISSO NÃO OCORRE ... OCORRE MAIS QUANDO É NECESSÁRIO ... O PRESIDENTE DO CONSELHO PARTICIPA DA REUNIÃO DA DIRETORIA EXECUTIVA ENTÃO ESTÁ SEMPRE À PAR

Uma característica marcante da Entidade 2 é dada pela relação com o espiritismo - há uma identificação clara com a doutrina espírita, que atua como fator agregador das pessoas:

OS ELEMENTOS DA DIRETORIA, ELES TINHAM UM VÍNCULO POR AFINIDADE RELIGIOSA SOMOS ESPÍRITAS E ATRAVÉS DA DOUTRINA ESPÍRITA A GENTE TEM PROCURADO REALIZAR UM POUCO DAQUILO QUE APRENDEMOS DE ACORDO COM O EVANGELHO DE JESUS ... A PRÁTICA DA CARIDADE, PROCURANDO SERVIR O NOSSO PRÓXIMO DA MELHOR FORMA POSSÍVEL TODO CONSELHEIRO NA NOSSA INSTITUIÇÃO É ESPÍRITA ... ISSO FAZ PARTE DA INSTITUIÇÃO MÃE, DO CENTRO EsPíRITA ...

Nós ESPÍRITAS TEMOS SEMPRE AQUELA CONVICÇÃO DO TRABALHO EM PR OL DO PRÓXIMO ... EU TINHA 8 ANOS, MINHA MÃE ME LEVAVA PARA AJUDAR A SERVIR SOPA PARA AS CRIANÇAS... HOJE EU FAÇO PORQUE GOSTO, PORQUE DÁ PRAZER... NÃO É SÓ TRABALHO COM A CRIANÇA ... EU ESTOU AQUI POR UMA QUESTÃO DE IDENTIDADE IDEOLÓGICA E AFINIDADE COM AS PESSOAS QUE FAZEM PARTE DA INSTITUIÇÃO ESTE TRABALHO JÁ ESTÁ INCORPORADO AOS MEU S OBJETIVOS DE VIDA E DA MINHA FAMÍLIA... A MINHA ESPOSA É CONSELHEIRA ... NA MINHA CASA SE VIVENCIA A INSTITUIÇÃO... IDEALIZAMOS ÀS VEZES PROJETOS, MEIOS DE ANGARIARMOS DINHEIRO ... PARA MANTER A INSTITUIÇÃO

\subsubsection{O Papel do Conselho nos Incidentes Críticos}

Nas entrevistas com os representantes da Entidade 2 foram descritos 4 incidentes críticos:

- Um momento financeiramente crítico, quando não se tinha dinheiro para pagar a folha de pagamento e o $13^{\circ}$ salário dos funcionários. O conselho participou da decisão de assumir ou não um serviço para uma grande empresa que poderia gerar os recursos faltantes, bem como ajudou na sua execução.

AQUiLO REALMENTE ESTA VA NOS INCOMODANDO ... ERA UMA PREOCUPAÇÃO NÃO SÓ PARA A DIRETORIA EXECUTIVA, COMO PARA OS CONSELHEIROS ... COMO NÓS IRÍAMOS FAZER PARA SAIR DAQUELE ...? ... A GENTE SEMPRE CONFIA EMDEUS ... A FÉ ACABA PREVALECENDO...

A [EMPRESA] ... COMO ELA FAZIA TODOS OS ANOS ... ABRIU UMA CONCORRÊNCIA PARA QUE A EMPRESA QUE OFERECESSE O MELHOR PREÇO, A MELHOR ESTRUTURA PARA EMBALAR AS CESTAS DE NATAL DOS SEUS FUNCIONÁRIOS ... ERAM 9000 CESTAS ... GANHOU UMA EMPRESA, QUE APRESENTOU O MENOR PREÇO ... ESSA EMPRESA NÃO OFERECIA CONDIÇÕES DE HIGIENE ADEQUADAS ... MAS ELES NÃO TINHAM MAIS TEMPO HÁBIL PARA ABRIR NOVAMENTE UMA CONCORRÊNCIA 
UMA PESSOA SUGERIU LÁ PARA A DIREÇÃO SE NÃO PODERIA ESTAR OFERECENDO PARA OS VOLUNTÁRIOS DA[ENTIDADE 2] ESTAREM FAZENDO ESSE TRABALHO ... NA ÉPOCA O VALOR FINANCEIRO COBRIRIA TODAS AS NOSSAS DESPESAS E AINDA SOBRARIA ALGUMA COISA

FoI FEITA UMA REUNIÃo COM TODOS OS COLABORADORES E CONSELHEIROS ... NÓS ASSUMIRÍAMOS OU NÃO AQUELA EMPREITADA? ... NÓS NÃO GASTARÍAMOS NADA ... A ÚNICA COISA QUE NÓS GASTARÍAMOS SERIA A MÃO DE OBRA... TERÍAMOS QUE REQUISITAR MAIS VOLUNTÁRIOS PARA FAZER ESSE TRABALHO, NÃO SÓ O TRABALHO DO S CONSEL HEIROS ...

NAQUELA OCASIÃO O CONSELHO FOI DECISIVO PORQUE ACEITOU SEM TER VIVENCIADO EXPERIÊNCIAS ANTERIORES ... ACEITOU MUITO MAIS PELO IDEAL, PELA VONTADE... ENTÃo NÓS LEVAMOS O NOSSO OK PARA A [EMPRESA]

FoI UMA EXPERIÊNCIA EXTREMAMENTE POSITIVA ... CONSEGUIMOS! ... A PARTIR DAQUELE ANO A INSTITUIÇÃO JÁ TINHAESSE COMPROMISSO COM A [EMPRESA]: FINAL DO ANO NÓS É QUE FARÍAMOS A EMBALAGEM DOS PRODUTOS ... A CADA ANO A COISA FOI MELHORANDO ... COMO NO NOSSO CORPO DE CONSELHO EXISTEM PROFISSIONAIS DE LOGÍSTICA NÃO FOI MUITO DIF́CIL ...... SÓ PARAMOS QUANDO OUTRA EMPRESA COMPROU A [EMPRESA] ...

- A formação de uma comissão de arrecadação. Em virtude das dificuldades financeiras freqüentes na entidade, dois conselheiros decidiram criar e dirigir uma comissão de arrecadação.

FOI FORMADA O ANO PASSADO ... DIRIGIDA POR UM OU DOIS ELEMENTOS DO CONSELHO ... A FINALIDADE É BUSCAR NOVOS MEIOS PARA A ARRECADAÇÃO ... INOVAR

ELES DECIDIRAM FORMAR UMA EQUIPE ... OS CONSELHEIROS ... NO BATE BOLA ... ISSO TEM MUITO NA INSTITUIÇÃO ...

Nós SENDO AGREGADOS AO CENTRO ESPÍRITA, NÃO JURIDICAMENTE FALANDO, MAS FUNCIONALMENTE, EMOCIONALMENTE ... NÓS NOS REUNIMOS MAIS DO QUE SE FOSSE APENAS A ENTIDADE ... TEMOS AS REUNIÕES PÚ BLICAS ÀS QUARTAS-FEIRAS, DOMINGOS, AOS SÁBADOS ... NESSAS HORAS, HORA DO LANCHE, "COMO É QUE VAMOS FAZER TAL COISA ? ... ESTÁ NO VERMELHO ... VAMOS FAZER UMA RIFA" ... ENTÃO SURGIU ESSA COMISSÃO DE ARRECADAÇÃO ...

- A diretoria propôs a realização de eventos mais audaciosos ao conselho, para captação de recursos. Os conselheiros participaram na viabilização dos eventos.

EVENTOS MAIS AUDACIOSOS ... POR EXEMPLO, RIFA DE CARRO COM JANTAR DANÇANTE ... O PESSOAL FICOU DE CABELO EM PÉ, VENDEMOS A R\$150,00 POR CONVITE ... TODO MUNDO FICOU APAVORADO O 20 FOI O ANO PASSADO ... 300 CONVITES A R $\$ 150,00$... PAGA O CARRO E TUDO MAIS ... SOBRA DE 15 A 20 MIL REAIS ... É UM PROJETO AUDACIOSO

(A PARTICIPAÇÃO do CONSELHO) FOI NA VENDA DE CONVITES, CHIANDO, BRIGANDO ... UM VENDE DOIS, OUTRO VENDE CINCO, OUTRO VENDE QUATRO, OUTRO NÃO VENDE ... PORQUE ... É MUITO HETEROGÊNEO, TEM QUEM CONSEGUE PASSAR E TEM AQUELE QUE NÃO CONSEGUE PASSAR ... ESSA É A PARTICIPAÇÃO

QuANDO A GENTE FEZ A RIFA DO CARRO, TEVE GENTE QUE SAIU CORRENDO DE COSTAS ... "E SE NÃO DER ?" ... O QUE FIZ EU: ... ANTES DE LEVAR A IDÉIA DO CARRO EU CONSULTEI VÁRIOS AMIGOS PARA VER QUANTO ELES COMPRAVAM ... EU VENDI O PREÇO QUE O CARRO CUSTAVA ... QUANDO EU VENDI O PREÇO QUE O CARRO CUSTAVA, EU CHEGUEI PARA O PESSOAL E FALEI: VAMOS FAZER ISSO, EU JÁ TENHO COLOCADO O PREÇO DO CAR RO ... O QUE DE PIOR PODE ACONTECER: A GENTE SAIR DO JEITO 
QUE ESTÁ ENTRANDO... E SE CONCORRERMOS COM UM MUNDO DE NÚMEROS, TALVEZ GANHEMOS O CARRO ...

DEU CERTO, PODIA TER DADO ERRAD O... TANTO QUE A GENTE REPETIU, JÁ ESTAMOS PROGRAMANDO PARA O ANO QUE VEM

- Déficit financeiro de $\mathrm{R} \$ 28$ mil. Os conselheiros participaram de uma campanha para conseguir aumentar o número de sócios.

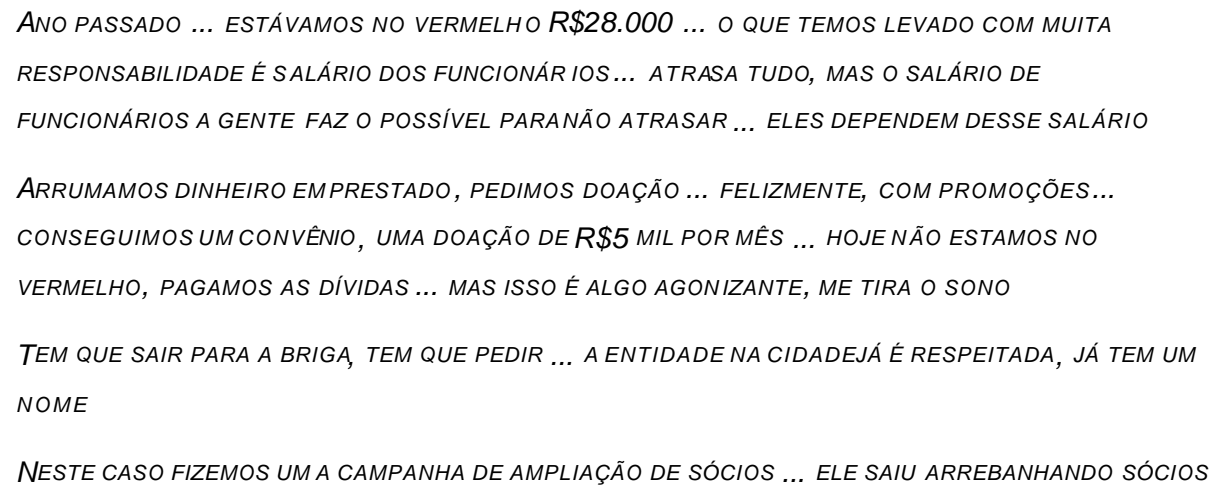

Pelos incidentes narrados pode-se perceber que na Entidade 2 a atuação do conselho se dá menos em grupo e em reuniões e mais em comissões e por esforços individuais. A coordenação do trabalho fica a cargo da diretoria, que demonstra habilidade em aproveitar bem tanto os talentos profissionais individuais, quanto as relações e a disponibilidade física de todos os colaboradores (os conselheiros "põem a mão na massa").

Neste esquema, nota-se que existe um bom nível de interação informal entre os conselheiros e que o conselho se mobiliza quando assume uma meta concreta e palpável, dentro de um prazo relativamente curto. O estabelecimento de metas, liderado pela diretoria executiva, parece ter grande importância, na medida em que dá a direção e aglutina os esforços.

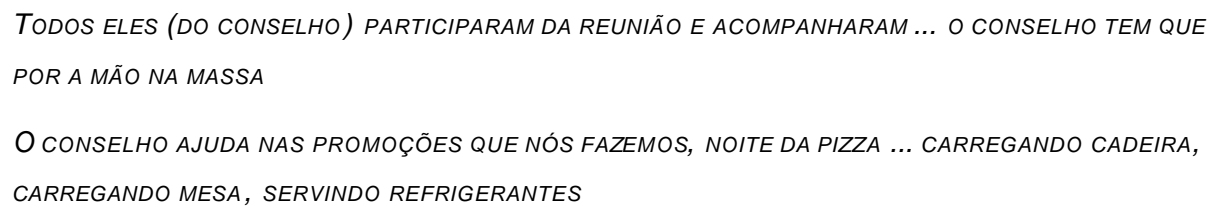

O conselho parece ser importante para a organização como recurso: trabalho voluntário, conhecimento técnico e contatos pessoais. A organização é administrada e governada pela diretoria executiva, com uma influência marcante da sua principal fundadora - praticamente as mesmas pessoas têm ocupado a liderança administrativa há vários anos.

Especialmente em situações de emergência o conselho ocupa um papel importante, mostrando-se sensível ao problema da casa, mobilizando os esforços necessários para solucioná-la.

Há uma diferenciação sutil entre o conselho e a diretoria - a diretoria representa o grupo carregador da instituição e o conselho o grupo apoiador. Embora no papel existam dois grupos dirigentes, a diretoria executiva e o conselho diretor, na prática, porém, existe um grupo realmente dirigente - administrador e 
governador - e um grupo de apoio, composto por voluntários. O trabalho técnico é realizado por uma equipe de profissionais contratados. Destaca-se o potencial da colaboração entre ambos - a parceria entre diretoria executiva e o trabalho dos conselheiros é um ponto forte desta entidade:

(SE NÃO HOUVESSE O CONSELHO) NÃO SERIA [ENTIDADE 2], PORQUE NÓS SOMOS A SOMA

A DIFERENCIAÇÃo É QUE A DIRETORIA EXECUTIVA É AQUELA QUE EXECUTA, AQUELA QUE ESTÁ TODO DIA NO BATE BOLA, TODOS OS DIAS SOLUCIONANDO PROBLEMAS... SÃO OS 4 OU 5 QUE VÃO, QUE ESTÃO, QUE SE DEDICAM POR POSSIBILIDADE ...

NÃO QUE OS OUTROS NÃO QUEIRAM ... OS NOSSOS PRÓPRIOS DIRETORES, TODOS ELES TRABALHAM, TÊM A SUA FAMÍLIA PARA CUIDAR

QUALQUER UM DECIDIU, ALGUÉM TEVE A IDÉIA, JOGOU A IDÉIA E TODO MUNDO ABRAÇOU... É A EQUIPE QUE FUNCIONA

(DISTINÇÃo ENTRE CONSELHO E DIRETORIA NA PRÁTICA) ÀS VEZES É DIFÍCIL ... GERALMENTE A GENTE TEM REUNIÕES DE DIRETORIA EXECUTIVA COM A PRESENÇA DE CONSELHEIROS... A GENTE PROCURA UM PERFIL

A DIRETORIA EXECUTIVA É AQUELA QUE TOMA AS PEQUENAS DECISÕES, AS DECISÕES DE ORDEM ADMINISTRATIVA

QUANDO TEM QUE REALMENTE FAZER UMA COISA MAIOR, OBRA MAIOR, POR EXEMPLO A CONSTRUÇÃO DESTE PRÉDIO... TIVEMOS QUE REUNIR O CONSELHO ... SÃO MUITO MAIS PESSOAS PENSANDO

O comentário...

NO REAL O CONSELHEIRO É UM VOLUNTÁRIO, ELE É UM TRABALHADOR ... ELE TEM OPORTUNIDADEDE EXTERNAR AS SUAS IDÉIAS, DE DAR AS SUAS SUGESTÕES, MAS ELE VAI EXECUTAR TAMBÉM, ELE NÃO VAI DELEGAR PARA ALGUÉM FAZER

... dá uma boa dimensão do estilo de trabalho dos conselheiros. Há um reconhecimento formal do papel deste grupo para a entidade, que é muito mais de ajudar na solução de problemas e na realização de tarefas, do que de definição de rumos. O direcionamento da entidade é dado pela diretoria executiva, com um influência explícita da fundadora.

O CONSELHO DE MODO GERAL, O PRESIDENTE DO CONSELHO PARTICIPA DESSA REUNIÃO DE DIRETORIA, ESTÁ JUNTO COM ESSA REUNIÃO DE DIRETORIA ... A ATUAÇÃO DO CONSELHO SERIA, ENTRE ASPAS, DE ASSESSORAR A DIRETORIA ...

Neste contexto, pelo menos os seguintes resultados podem ser atribuídos diretamente à existência do conselho, ou melhor, dos conselheiros: (a) superação de situações financeiras críticas; (b) maior número de convites, rifas, cestas, etc., vendidos. Os comentários do conselheiro podem indicar que o desempenho do conselho é limitado, na opinião dele, pelo limite da dedicação dos conselheiros - o conselho restringe-se a fazer "aquilo que é possível fazer" no tempo disponível, o que também é uma característica cultural da Entidade 2.

\subsubsection{Competências desenvolvingidas}

A análise do trabalho do conselho e da diretoria a partir das competências é feita a seguir: 
Dimensão analítica: o processo de análise dos problemas se dá: informalmente, em reuniões do centro espírita; em conversas com as pessoas da diretoria; em reuniões da diretoria; ou em reuniões abertas convocadas esporadicamente. Os relatos acima demonstram pouca preocupação em analisar problemas em detalhes, em dedicar tempo para esmiuçá-los, em explorar diferenças de opinião e examinar questões sob diferentes pontos de vista. A presença de uma liderança forte e fundadora parece contribuir para isso, trazendo muito mais propostas praticamente prontas para o conselho, para aprovação, e poucas perguntas realmente desafiadoras.

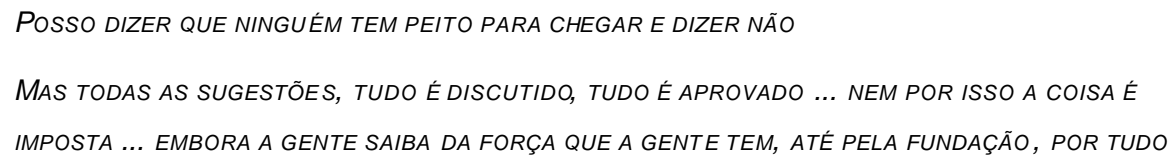

Dimensão contextual: os valores da organização estão muito permeados pela doutrina espírita, da qual a grande maioria dos dirigentes (se não todos) está relacionado - há uma grande identificação com a causa e com os princípios da entidade. Estes valores são reforçados nos encontros informais no centro espírita, demonstrando que os conselheiros consideram a cultura da organização e a reforçam continuamente. Além do mais, parece que a presença dos conselheiros e diretores é constante tanto na entidade quanto no Centro, dando oportunidade para manterem-se àpar do que acontece e de quem está lá.

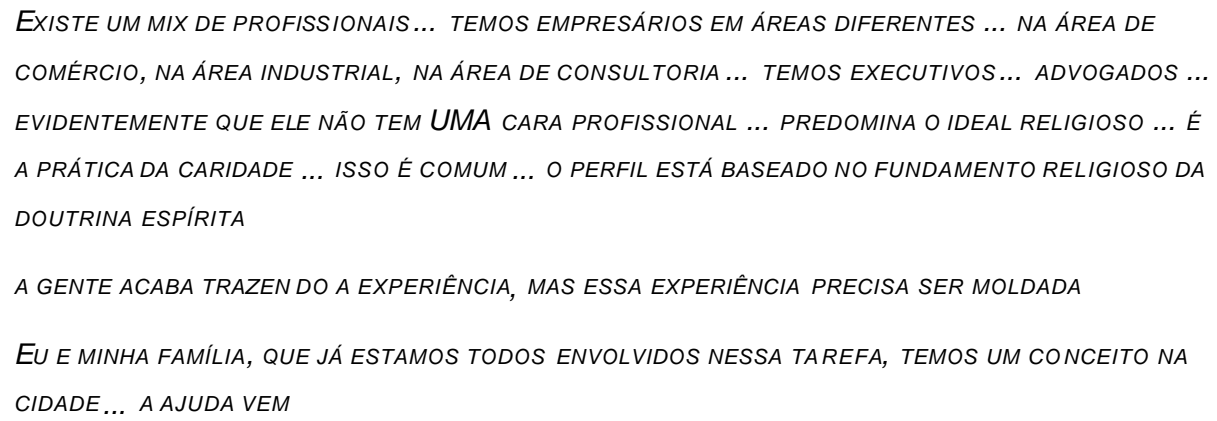

Dimensão educacional: a fundadora comentou que houve alguns cursos na área de $\mathrm{RH}$ e que a preocupação do grupo era não cristalizar; no caso das cestas de Natal houve uma preocupação em melhorar o serviço a partir das experiências anteriores. Entretanto, nenhum dos entrevistados conseguiu identificar um erro cometido, indicando que este tipo de reflexão não é muito comum, nem no conselho, nem na diretoria.

As perguntas levantadas na avaliação desta dimensão com os dados dos questionários parecem ser pertinentes para a Entidade 2: nela, parece existir uma cultura de que o esforço voluntário não deve ser avaliado ou criticado, sob um pressuposto comum de que cada um já está fazendo o melhor que pode...

O ESTILO ... A GENTE TEM PROCURADO IMPLEMENTAR NOVAS TÉCNICAS, TEMOS TIDO CURSOS COM EQUIPES DE RH, PARA QUE A GENTE NÃO SE CRISTALIZE, QUE A GENTE SE ATUALIZE

A INSTITUIÇÃO ... ACABA SENDO UMA EMPRESA, ENTÃO VOCÊ TEM QUE TAMBÉM SE ATUALIZAR

MAIOR ERRO ... NÃO ME LEMBRO, SINCERAMENTE ... NÃO ACHO QUE TENHA NADA ASSIM

Honestamente eu NÃo SABERIA DIZER QUAL ERRO O CONSELHO COMETEU ...

NÃO QUE OS OUTROS NÃO QUEIRAM ... OS NOSSOS PRÓPRIOS DIRETORES, TODOS ELES TRABALHAM, TÊM A SUA FAMÍLIA PARA CUIDAR 
Eu GOSTARIA DE ESTAR FAZENDO MAIS, MAS HOJE A GENTE TEM UM PROBLEMA, QUE É O PROBLEMA DO TRABALHO ... É UMA INSTITUIÇÃO SEM FINS LUCRATIVOS, TODAS AS PESSOAS QUEAQUI TRABALHAM NÃO GANHAM UM TOSTÃO ...

A GENTE LUTA COM O ASPECTO TEMPO ... EU TENHO MEU GANHA-PÃO, MINHA ATIVIDADE PROFISSIONAL ...

A gRANDE DIFICULDADE HOJE ... DENTRO DAQUILO QUE É POSSÍVEL FAZER, EU ACHO QUE O CONSELHO É ATUANTE ... CADA UM TEM O SEU TR ABALHO PROFISSIONAL ... CADA UM DEDICA AS HORAS QUE PODE EM PROL DA INSTITUIÇÃO, NÃO PODE FICAR FULL-TIME PARA A INSTITUÇÃO ... ESTE É UM PROBLEMA HOJE QUE A INSTITUIÇÃO TEM ... NÃO É UMA INEFICIÊNOA DO CONSELHO ... AQUI NINGUÉM GANHA NADA MATERIALMENTE ... ELE TEM QUE DIVIDIR O SEU TEMPO (ENTRE O) PROFISSIONAL E A INSTITUIÇÃO

É EVIDENTE QUE QUAL É O TEMPO QUE SOBRA: É O FINAL DE SEMANA, ÀS NOITES... NEM TODAS AS NOITES AS PESSOAS PODEM ESTAR SE REUNINDO ... É COMUM FAZER UMA REUNIÃO E NÃO CONTAR COM A PRESENÇA DE $100 \%$ DOS CONSELHEIROS

VOCE TEM QUE ADMINISTRAR CONTANDO COM O POUQUINHO DE CADA UM ... UNS PODEM FAZER MAIS, OUTROS PODEM FAZER MENOS ... COM CERTEZA TODOS FAZEM O QUE PODEM

Dimensão estratégica: o direcionamento da instituição é, aparentemente, dado pelo carisma da fundadora e pela sua influência sobre a diretoria executiva. Há poucas citações de uma participação significativa do grupo de conselheiros sobre isso. Nota-se o envolvimento deles muito mais em situações emergenciais e na promoção de eventos. Todos os quatro incidentes relatados disseram respeito a questões financeiras, o que não deve ser coincidência: o conselho e a diretoria não vêm conseguindo resolver a contento este problema, convivendo com situações críticas, dando o máximo de si, mas dedicando pouco tempo a refletir sobre "por que isso vem se repetindo?" - a tendência comum é encontrar a diretoria executiva fazendo-se regularmente a pergunta "como podemos superar esta situação?".

Dimensão interpessoal: os diretores executivos e alguns conselheiros reúnem-se regularmente, estão freqüentemente na entidade, encontram-se no Centro Espírita - isso cria oportunidades para que haja o desenvolvimento do grupo, embora inconscientemente reforce -se os esforços individuais. A diretoria utilizase da sua autoridade formal e da presença dos fundadores para exercer liderança; tem uma preocupação prática de definir metas claras e concretas e comunicar aos demais conselheiros, o que, como já foi dito, é uma grande qualidade desta instituição. No entanto, o cultivo de novas lideranças é pouco citado - ao contrário, a diretoria vem sendo reeleita há bastante tempo e convive com uma insegurança a respeito da entrada de outras pessoas. O processo de renovação é informal, baseado no contato pessoal eventual, provavelmente no Centro Espírita.

É UMA ADMINISTRAÇÃO BEM DEMOCRÁTICA ...

AS PESSOAS TÊM SEMPRE ELEGIDO A MESMA DIRETORIA...

(MANDATO) SINCERAMENTE EU NÃO SEI ... A GENTE NÃO SE PREOC UPA COM ISSO ... EU ESTOU AQUI

PARA TRABALHAR, PARA CONTRIBUIR ...

(ESTOU) NA INSTITUIÇÃO DESDE 1986, HÁ 14 ANOS ... (PRETENDO CONTINUAR) ATÉ MORRER ...

DEUS É QUE SABE 


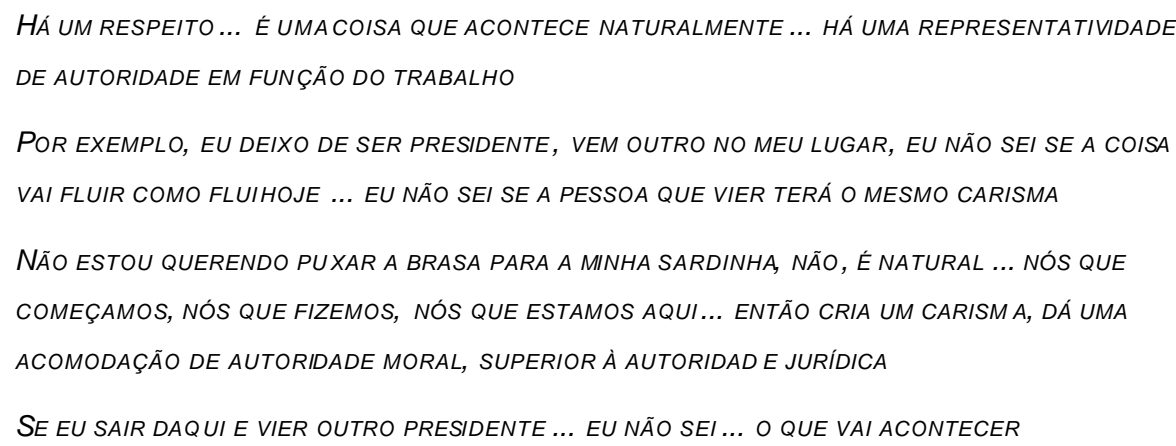

Dimensão política: a diretoria mostra uma preocupação de manter as relações saudáveis com os voluntários e profissionais da instituição. Os voluntários do conselho diretor e mesmo os da diretoria executiva mostram um respeito muito grande pelo papel da fundadora, reconhecendo seu papel legítimo de liderança institucional. Embora os conselheiros participem de comissões, nas quais devem ter uma chance maior de comunicarem-se diretamente com as principais audiências da organização, não há esforços em envolver outras audiências nos processos de decisão em relação àentidade.

\subsubsection{ENTIDADE 10}

\subsubsection{Contexto instititụcionnal}

A organização objeto desta pesquisa é um "departamento" de um Centro Espírita. Foi fundado em 1972 e abriga 120 meninos e meninas de 0 a 17 anos que se encontram em situação de abandono. Oferece, além de amparo emocional e social, uma estrutura adequada para o desenvolvimento integral das crianças. $\mathrm{O}$ Centro Espírita, fundado em 1967, tem como objetivos promover e desenvolver a fraternidade universal, aplicando os Evangelhos de Jesus Cristo, à luz da doutrina espírita, e manter, sob guarda e tutela, gratuitamente, órfãos, abandonados e carentes. O Centro Espírita cumpre seu objetivo através de núcleos de estudos, jornal, biblioteca e departamentos filantrópicos beneficentes - um destes departamentos é a organização objeto desta pesquisa.

A liderança executiva entrevistada é a presidente da diretoria executiva, que trabalha na entidade desde a sua abertura - inicialmente era voluntária, atualmente é remunerada. Ela está nesta posição há 17 anos.

TENHO 58 ANOS, SOU FORMADA NO MAGISTÉRIO ... COMECEI AQUI POR CAU SA DA MINHA MÃE QUE ERA VOLUNTÁRIA ... EU ESTOU AQUI DESDE QUE FOI ABERTA A CASA...

CONHEÇO TODOS OS DEPARTAMENTOS, PORQUE EU PASSEI POR TODOS ELES COMO VOL UNTÁRIADESDE A LAVANDERIA A TÉ REFORÇO ESCOLAR ... ATÉ QUE UM DIA ACABEI NA PRESIDÊNCIA ... DIFÍCIL AGORA É SAIR DA PRESIDÊNCIA, PORQUE NINGUÉM QUER POR FALTA DE DISPONIBILIDADE DE TEMPO E FINANCEIRO ... ESTOU HÁ 17 ANOS NA PRESIDÊNCIA (1982/83)

QUANDO EU PEGUEI AQUI A CASA ... COMO ERAM SÓ HOMENS QUE ERAM PRESIDENTES ... DEU UMA DIFERENÇA MUITO GRANDE ... A MULHER ACABA TRATANDO AQUI COMO UM GRANDE LAR ... AS CRIANÇAS E OS JOVENS, EU ME IDENTIFIQUEI MUITO BEM COM ELES ... A MINHA PROFISSÃO JÁ ERA MESMO LIGADA A MENORES

A geNTE PROCUROU ORGANIZAR AQUI, FAZER UMA ORGANIZAÇÃO MELHOR NA CASA ... FOI SE CRIANDO OS DEPARTAMENTOS ... PSICÓLOGA, PROFESSORAS, ASSISTENTE SOCIAL ... É UMA 
CONQUISTA, PORQUE NÃO HÁ VERBAS SUFICIENTES PARA FAZER TUDO ... CONSEGUINDO PONDO

METAS ... HOJE A GENTE TEM ATÉ UM DEPARTAMENTO DE MARKETING, QUE ESTÁ ENGATINHANDO, MAS

JÁ AJUDA BEM A ENTIDADE

A representante do conselho é bastante jovem, tem apenas 24 anos, mas esá há mais de 6 anos trabalhando voluntariamente na entidade. Assim, tanto a executiva quanto a conselheira trabalharam como voluntárias antes de tornarem-se membros da diretoria e conselho.

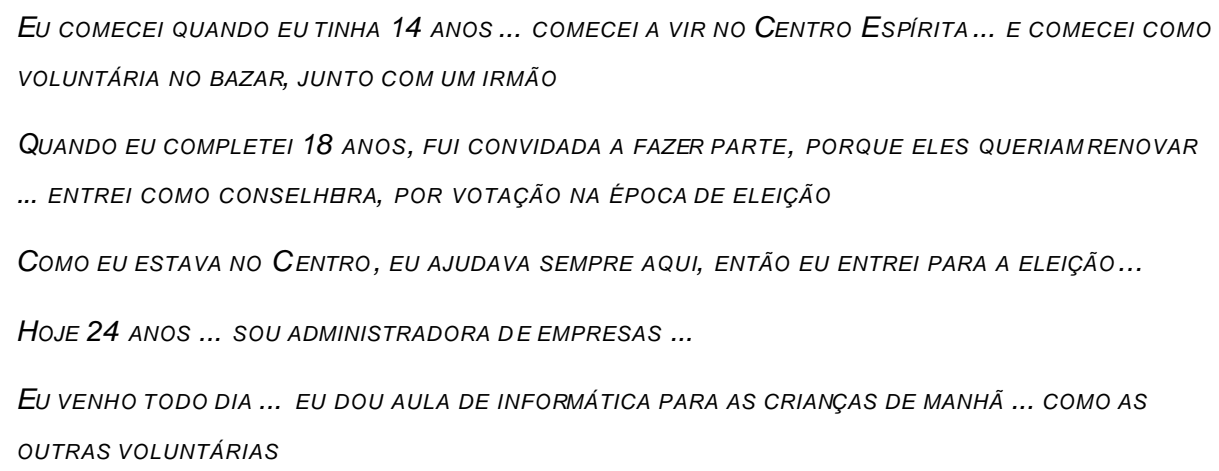

Segundo o estatuto, os Poderes constituídos são:

I. Assembl éia Geral: constitui-se no Poder Soberano do Centro, sendo convocada anualmente.

II. Conselho Deliberativo: composto por 33 membros e 12 suplentes, divididos em 3 grupos, com mandato de 9 anos cada um. De três em três anos renova-se um grupo de conselheiros, através de eleição. O estatuto diz que o conselho reúne-se trimestralmente e tem como atribuições eleger os membros do Conselho Fiscal e Diretoria Executiva, julgar o balanço geral e o relatório anual da Diretoria, homologar o balancete, destituir e substituir qualquer diretor, deliberar sobre assuntos de urgência, julgar recursos interpostos e aplicar penalidades.

III. Conselho Fiscal: compõese de 3 membros e 2 suplentes; é responsável por examinar os balancetes mensais, examinar periodicamente a situação econômica financeira, emitir parecer sobre o balanço geral e denunciar qualquer irregularidade.

IV. Diretoria Executiva: é composta por 9 membros, conselheiros, eleitos pelo Conselho Deliberativo, sendo o órgão administrativo da Sociedade. O mandato dos diretores é de 3 anos.

ATIVOS NA DIRETORIA EXECUTIVA: 9 ... TEM 3 NA DIRETORIA FISCAL E 3 NA DELIBERATIVA

A MAIORIA HOJE ESTÁ COM 73 (ANOS) PARA CIMA ... MEU CONSELHO ... SÃO MUITO DE IDADE ... AGORA QUE EU ESTOU CHAMANDO UM PESSOAL MAIS JOVEM ... A MAIORIA SÃO PESS OAS DA TERCEIRA

IDADE ... TÊM COMO VIR... OS QUE TRABALHAM, NÃO

Muitos atuam na casa, outros nÃo ... ESTE ANO ... JANEIRO, MAIO E OUTUBRO ... REUNIÕES ... E DE DIRETORIA TIVEMOS 8

AQUI É ANTIGO, ENTÃO A MAIORIA DOS DIRETORES E CONSELHEIROS ... ANTIGOS, DE IDADE ELEVADA VÃO SAINDO, VÃO DEIXANDO DE PARTICIPAR... VIERAM CHAMANDO OS QUE MAIS FREQÜENTAM O ORFANATO, QUE ESTÃO SEMPRE ALI

NÃo ADIANTA COLOCAR UMA PESSOA PARA FAZER PARTE DA DIRETORIA OU CONSELHEIRO QUE NÃO FREQÜENTA, QUE NÃO SABE DOS PROBLEMAS OU NÃO TEM INTERESSE 


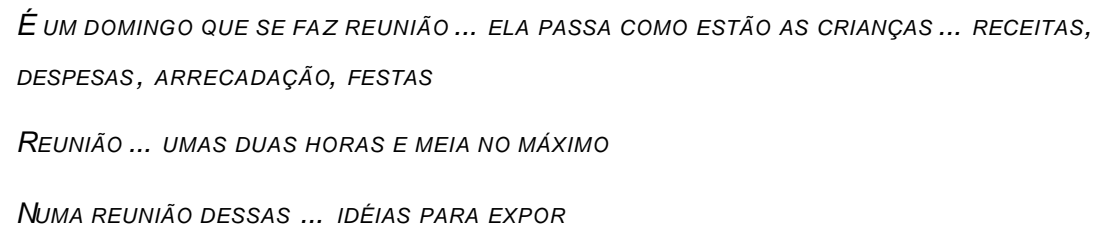

Os comentários até aqui mostram que uma questão presente é a renovação dos membros da diretoria e conselho. A executiva tem uma relação quase de fundadora com a instituição, como "mãe da casa" e ambas têm um vínculo grande com a entidade, dedicando-se a ela há bastante tempo. Porém, a executiva sente-se bastante sobrecarregada na entidade...

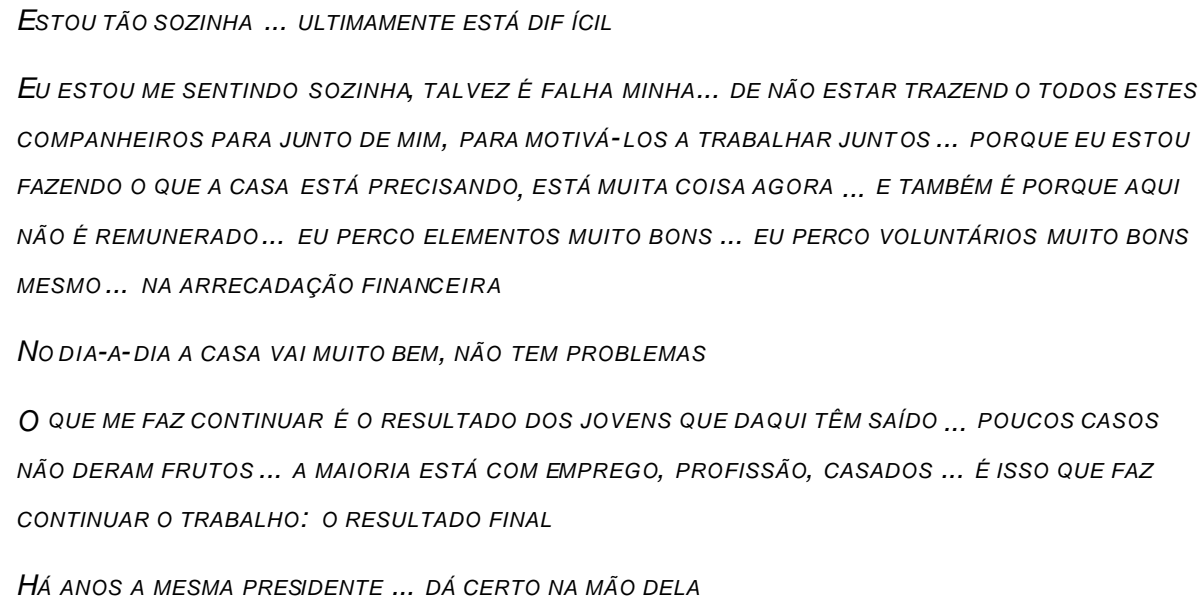

\subsubsection{O Papel do Conselho no nos Incidententes Crítíticos}

Foram 6 os incidentes relatados pelas entrevistadas que tiveram participação do conselho e da diretoria. Os casos eram referentes:

- Criação de uma préescola. O conselho e a diretoria juntos discutiram os problemas de acesso das crianças àescola e tiveram a idéia de criar a pré-escola.

JÁ FAZ UNS 10 ANOS ... TODOS COLABORARAM MUITO, SE ENTUSIASMARAM PARA QUE A GENTE CONSEGUISSE MESMO IMPLANTAR

As CRIANÇAS IAM PARA AS ESCOLAS EMEIS... UM POUCO LONGE ... NÃO PODÍAMOS PAGAR TRANSPORTE PARA TODAS AS CRIANÇAS ... ELES TINHAM QUE IR À PÉ... ERA MAU TEMPO, CALOR, ESSAS CRIANÇAS SEMPRE EXPOSTAS À CHUVA ... AO TRÁFEGO ... A UM ACIDENTE

A GENTE ANALISANDO O TRANSPORTE ... O CONSELHO, NÓS TODOS RESOLVEMOS PAGAR O TRANSPORTE PARA AS CRIANÇAS, MAS FICAVA CARÍSSIMO ... TIVEMOS A IDÉIA DE IMPLANTAR A PRÉESCOLA AQUI MESMO NACASA ... TODOS ACHARAM EXCELENTE A IDÉIA ... UM TERÇO DO CONSELHO, UMAS 11, 12 PESSOAS PARTICIPARAM MESMO

Nós TÍNHAMOS QUE FAZER O PROJETO, PREPARAR O LOCAL PARA SE RECEBER AS CRIANÇAS ... HOUVE UMA REFORMA UMA RESTRUTURAÇÃO DAENTIDADE ... FOMOS FAZENDO DIVISÓRIAS ... ELES AJUDAVAM, PARTICIPAVAM, VINHAM COMO VOLUNTÁRIOS ... NO TRABALHO ... EM EVENTOS TAMBÉM, EM EVENTOS GRANDES ELES COLABORAM BASTANTE

ERA MAIS AS IDÉIAS NA REUNIÃO, A GENTE COLOCAVA EM PRÁTICA E TAMBÉM NO TRABALHO VOLUNTÁRIO DELES DE PINTURA DE REFORMAS DE BANHBROS, DE SALAS DE AULA ... FOI MAIS ISSO 
- Abrir um departamento de marketing. O conselho resistiu à proposta da presidente de abrir um departamento de marketing.

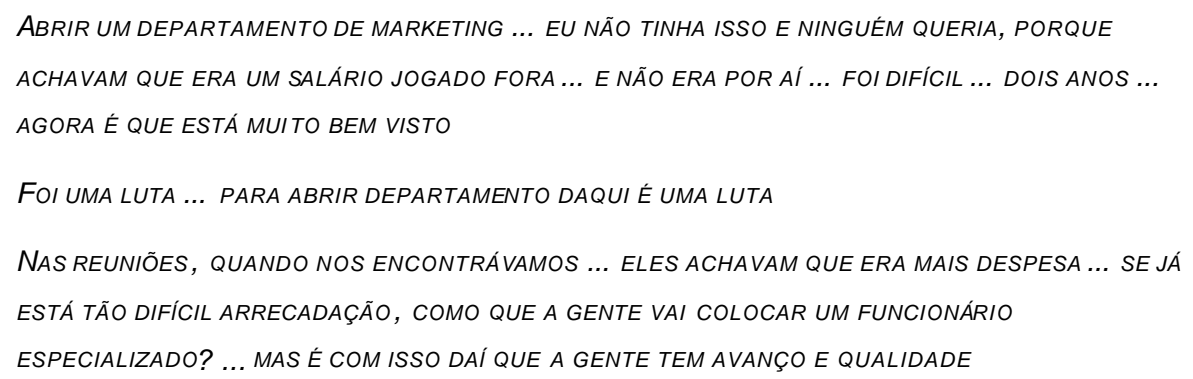

- Realizar uma feijoada. Os conselheiros mobilizaram-se para contribuir com a realização de uma feijoada.

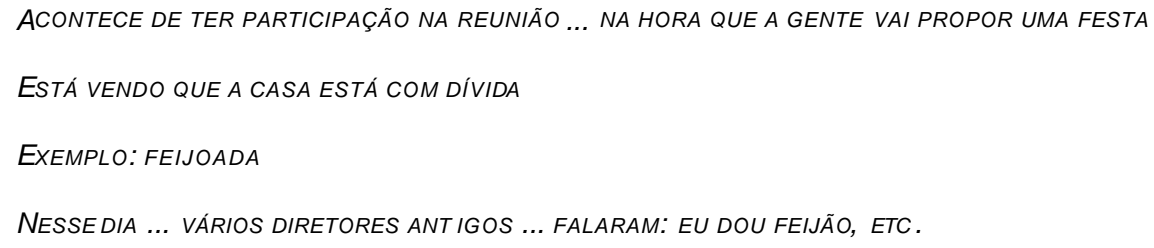

- Falta de dinheiro. O conselho ajuda a pensar em possíveis alternativas para superar fases em que há falta de dinheiro na entidade.

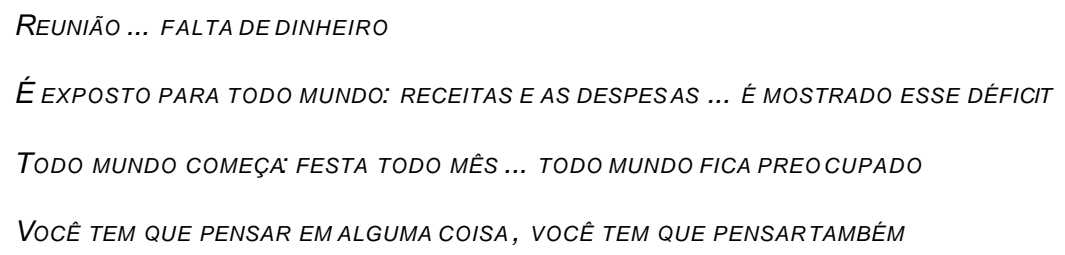

O pouco que foi comentado revela que alguns conselheiros que vão à entidade regularmente, têm contato com as crianças e participam de atividades de manutenção, como voluntários. O conselho também atua apoiando na realização de eventos e com idéias nas reuniões. O estilo de trabalho parece ser informal e apoiador, uma vez que a executiva exerce uma liderança forte, havendo uma preocupação aparente de manter as relações saudáveis. Há uma distância grande do conselho da realidade diária da entidade; apesar de muitos conselheiros conhecerem a entidade e seu público, estão pouco vinculados à iniciativa em si. A executiva atribui parte dessa desvinculação àidade dos conselheiros.

Individualmente alguns conselheiros se responsabilizam por determinadas atividades operacionais, como 0 envio de mala direta, por exemplo, e a venda de convites.

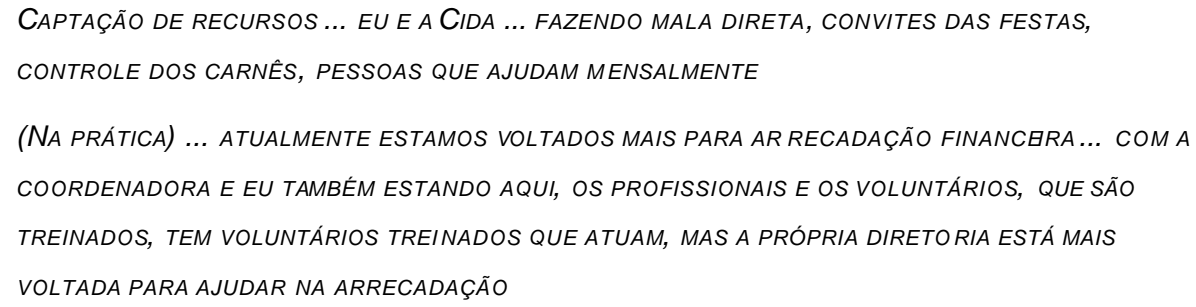




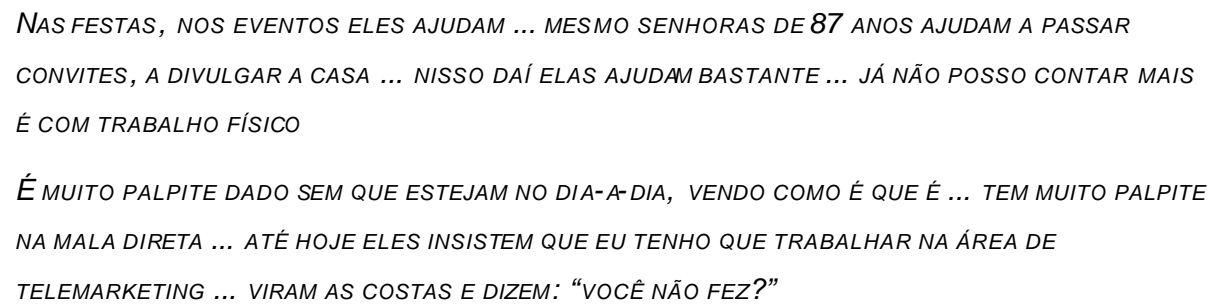

Qual é a importância deste conselho? Os casos e o contexto descritos sugerem que a importância do conselho está mais ligada à solução de problemas emergenciais (de uma criança, financeiros) e à realização de atividades pontuais. O conselho exerce pouca oposição, embora atue como "segurador" do ímpeto da executiva.

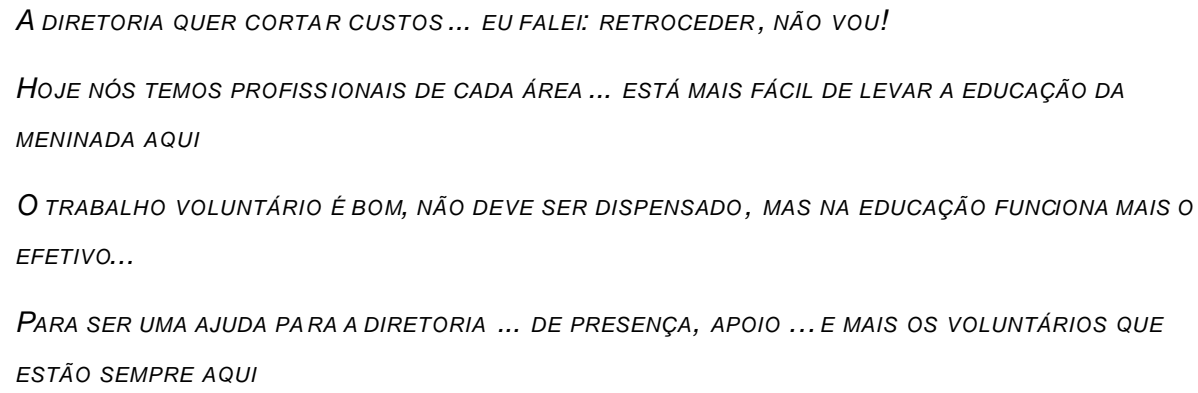

Não há aparentemente, pelo que este caso indica, uma definição clara de responsabilidades, nem da diretoria, nem do conselho, além daquelas do estatuto. A executiva exerce um papel de "mãe da casa", tendo, aparentemente, ampla autonomia para promover as mudanças que ache necessário na entidade.

O sentimento de isolamento e solidão da executiva indica que não há uma relação plena de parceria entre conselho e diretoria. A diretoria executiva administra a entidade e o conselho tem um papel meramente apoiador, numa relação quase de submissão. O apoio oferecido pelo conselho insatisfaz, sendo, como já foi dito, pontual, emergencial, específico e muitas vezes de manutenção. As relações são boas, especialmente pelos vínculos familiares existentes e, possivelmente, pela convivência no Centro Espírita.

ELES NÃO IMPEDEM QUE EU TRABALHE

A conselheira não faz uma distinção conceitual do papel do conselho ou da diretoria, por um lado, e tem uma visão restrita do conselho, como pode se depreender dos comentários:

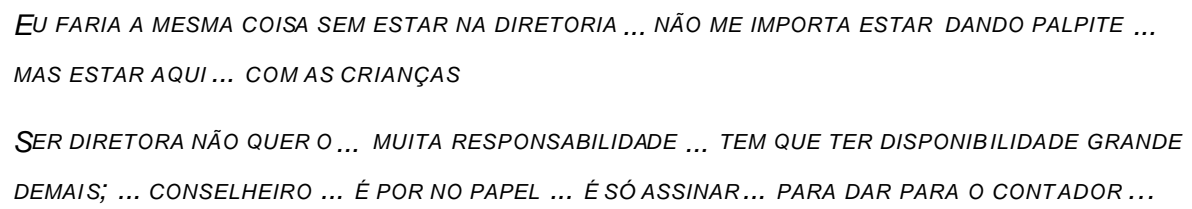

No contexto da Entidade 10 é muito difícil atribuir resultados significativos à atuação do conselho, exceto aqueles relacionados à venda de convites, apoio a eventos e tarefas eventuais. No caso da pré-escola o conselho parece ter sido responsável pela abertura de uma nova modalidade de atendimento, mas faz 10 anos... 


\subsubsection{Competências desenvolvidas}

Competência analítica: o conselho aparentemente tem pouca disposição para análise detalhada e aprofundada dos problemas; embora tenham sido fornecidas poucas informações para uma análise mais consistente, o conselho prefere submeter-se à iniciativa da executiva, trabalhando mais em eventos e em trabalhos de manutenção. A executiva neste ponto contribui para manter as coisas como estão, buscando com freqüência convencer os conselheiros, ao invés de ajudálos a pensar e a provocar o surgimento de pontos de vista diversos e divergentes. Os depoimentos sugerem ainda que o conselho tem o hábito de opinar sobre as atividades institucionais, o que irrita aquelas pessoas mais envolvidas no dia-a-dia.

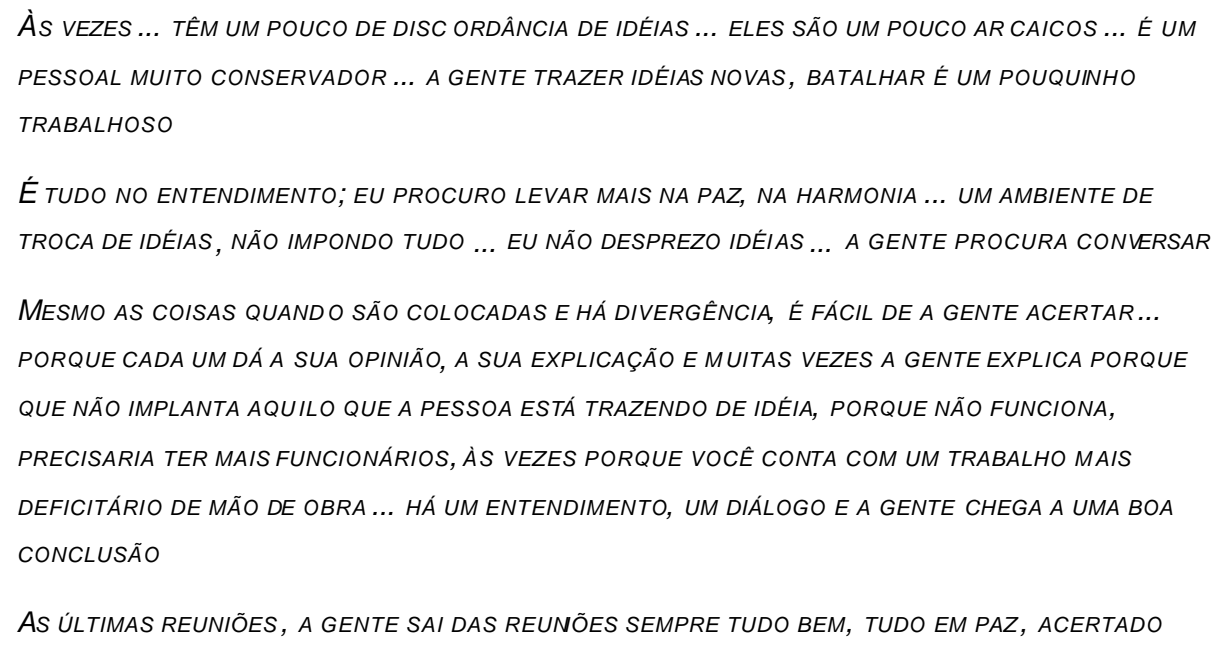

Competência contextual: o conselho conhece as normas e tradições da organização porque está vinculado a ela há muitos anos e a convivência no Centro Espírita parece facilitar a transmissão desta cultura. Porém, tudo acontece de maneira extremamente informal e circunstancial, não apare cendo nenhuma iniciativa por nutrir ou renovar tal cultura. Como quase fundadora, a executiva teve iniciativas em direção a alguma renovação, que tiveram que enfrentar a quase passividade dos conselheiros...

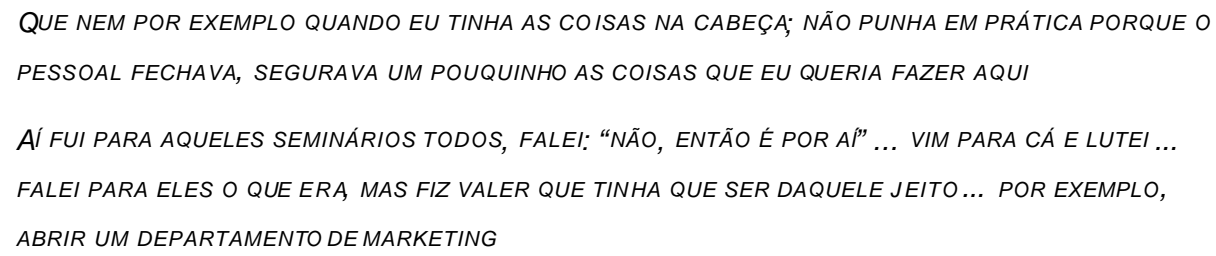

Competência educacional: é um conselho que preocupa-se quase nada em aprender sobre seu papel e suas responsabilidades. Não houve uma citação sequer de qualquer atividade educacional dos conselheiros, nem de auto -avaliação, nem de capacitação. $O$ desenvolvimento dos conselheiros depende da sua dedicação pessoal como voluntário...

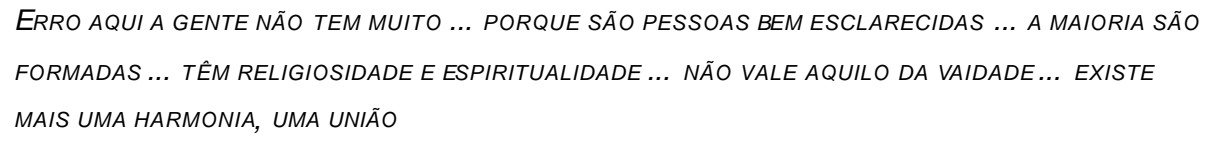

Competência estratégica: não é um conselho em que se destaca a qualidade estratégica. É um conselho mais preocupado com manter, preservar e não arriscar, do que em olhar para o futuro, definir metas e 
antecipar problemas. Na prática, a atuação do conselho em termos estratégicos é nula. Existe aparentemente uma dependência da presidente para isso.

Competência interpessoal: parece que um dos fatores que promovem uma certa agregação dos conselheiros é a vinculação ao Centro Espírita, que propicia um bom grau de conhecimento mútuo e estabelece bases para relações pessoais informais e cordiais. Entretanto, parece que as reuniões consistem num diálogo entre a presidente e os conselheiros e não existem metas assumidas em conjunto. Evidentemente, o processo sucessório também é incipiente e tratado de maneira improvisada.

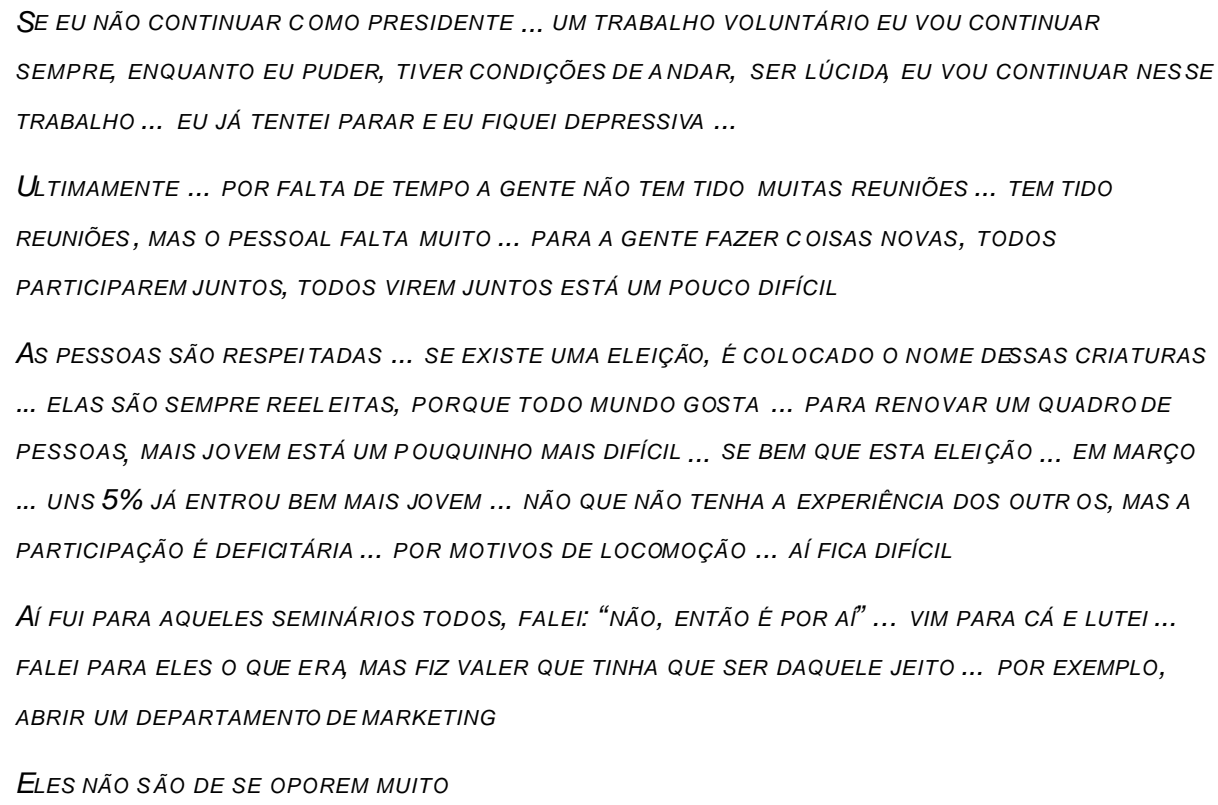

Competência política: do ponto de vista político, é um conselho que respeita o papel e a atuação da diretoria executiva. Comunica-se diretamente com os profissionais da equipe e conhece algumas crianças pessoalmente. Procura, aparentemente, minimizar conflitos e situações tensas que emperrem o trabalho da entidade. Não se vê, entretanto, qualquer iniciativa que vise integrar a entidade a constituintes externos ou a nutrir relações com parceiros - qualquer esforço para isso deve surgir, aparentemente, da presidente.

\subsubsection{ENTIDADE 8}

\subsubsection{Contexto institucional}

A Entidade 8 é uma fundação constituída em 1990, tendo por finalidade a defesa dos direitos da criança. Segundo seu estatuto, cabe-Ihe promover:

- A divulgação dos Direitos da Criança e mobilização da consciência coletiva para a importância e necessidade de que tais direitos sejam efetivamente respeitados;

- $\quad$ O estímulo, promoção e participação em projetos, ações, campanhas e estudos relativos aos Direitos da Criança;

- O estímulo e acompanhamento da situação legislativa referente à criança, aos direitos da criança e garantias; 
- A colaboração com entidades públicas e privadas em tudo que possa ser de interesse da criança;

- A promoção de intercâmbios, celebração de convênios e contratos com entidades públicas e privadas, nacionais e internacionais;

- $\quad$ A execução de outras atividades compatíveis com suas finalidades.

A Entidade 8 cresceu muito desde a sua constituição, por um grupo de empresários, tendo hoje 70 funcionários e um orçamento anual próximo de dois milhões de reais. Opera diversos projetos próprios e faz parcerias e convênios com diversas entidades do Brasil todo, orgulhando-se de sua origem e cultura "empresarial".

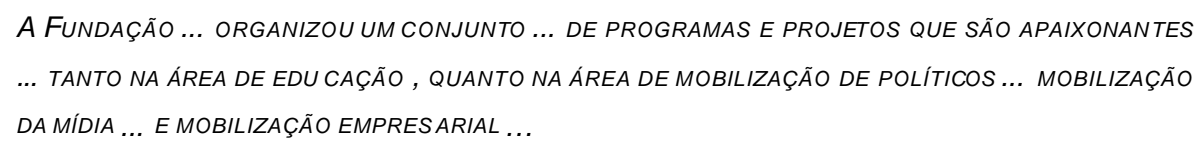

O conselheiro entrevistado é um empresário e executivo bastante ativo na instituição, que tem experiência no terceiro stor; tem experiência de conselho de administração de empresa, como executivo e como conselheiro:

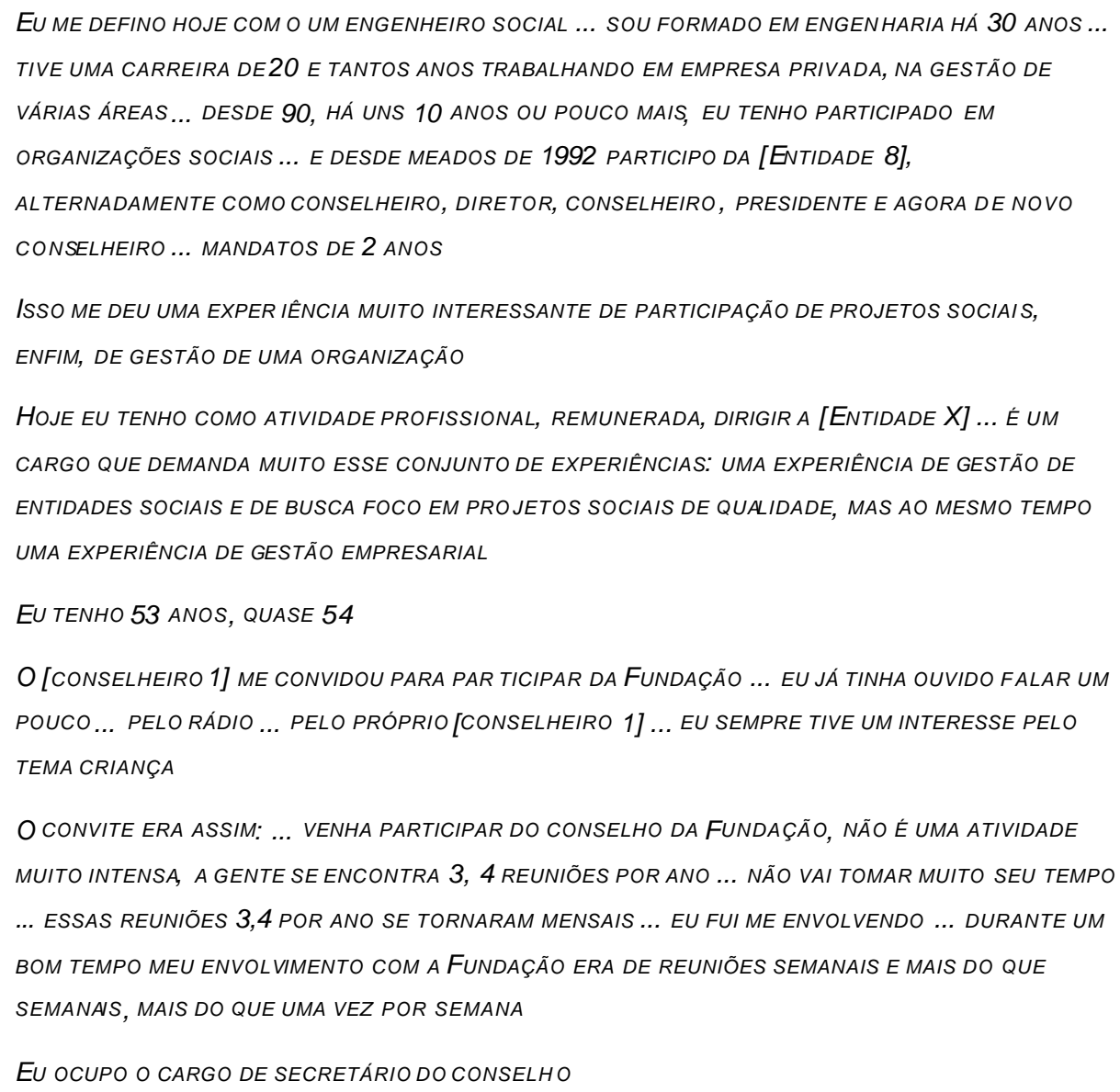

De acordo com o estatuto, são órgãos da [Entidade 8]:

(a) Conselho de Administração

(b) Diretoria 
(c) Conselho Consultivo

(d) Conselho Fiscal

O Conselho de Administração é integrado por 18 membros, com mandato de 2 anos, sendo:

- o presidente da diretoria executiva da instituidora,

- 7 membros efetivos e 3 suplentes, designados pela instituidora,

- 10 membros efetivos e 4 suplentes designados pelo próprio conselho de administração.

O conselho de administração é órgão de deliberação superior e de fiscalização, competindo-lhe especialmente:

a) fixar a orientação geral e traçar as diretrizes de atuação da Fundação, visando assegurar a consecução de seus fins;

b) eleger os membros da diretoria, dentre seus membros;

c) zelar pela estrita observância das disposições legais, estatutárias, regimentais e programáticas;

d) aprovar a previsão orçamentária e a proposta anual de atividades apresentada pela diretoria;

e) aprovar as prestações de contas e os relatórios anuais da diretoria;

f) elaborar o regimento interno;

g) deliberar sobre a extinção da Fundação e o destino do seu patrimônio.

O Conselho de Administração reúne-se ordinariamente, segundo o estatuto, duas vezes ao ano.

A Diretoria também tem mandato de 2 anos, sendo constitúda por 3 membros (presidente, vice-presidente e tesoureiro). A Diretoria tem como atribuições, segundo o estatuto:

a) administrar a [Entidade 8], obedecidas as diretrizes fixadas pelo Conselho de Administração;

b) superintender as atividades técnicas, administrativas e financeiras da Fundação;

c) cumprir e fazer cumprir as normas estatutárias, bem como as deliberações do Conselho de Administração;

d) submeter à apreciação prévia do Conselho de Administração os planos, programas de trabalho e respectivos orçamentos;

e) submeter àapreciação do Conselho de Administração as contas da Fundação;

f) apresentar o relatório das atividades do ano civil precedente;

g) praticar todos os demais atos de gestão administrativa.

O Conselho Consultivo é órgão de assessoramento, nomeado pelo Cons elho de Administração e constituído, sem limite de número, por pessoas naturais cujas atividades estejam ligadas à defesa dos direitos da criança. Tem um presidente e um vice-presidente, nomeados pelo Conselho de Administração, com mandato de 3 anos, reunindo-se quando convocado pelo seu presidente ou pelo presidente do conselho de administração. 


\section{Compete ao Conselho Consultivo:}

a) dar parecer sobre projetos, planos e atividades da Fundação;

b) elaborar sugestões e planos para a apreciação e aprovação do Conselho de Administração.

O Conselho Fiscal é órgão de assessoramento na fiscalização financeira-contábil, sendo composto por 3 membros efetivos e 3 suplentes, com mandato de 2 anos.

Algumas características dos conselhos são delineadas pela superintendente:

A INDICAÇÃO DOS NOMES DE QUEM VAI COMPOR .. É FEITA PELA PRÓPRIA LIDERANÇA DAFUNDAÇÃO NAQUELE MOMENTO ... O [CONSELHEIRO 1], NA VERDADE, EO [CONSELHEIRO 2] FORAM OS INSTITUIDORES DA FUNDAÇÃO, FORAM OS EMPRESÁRIOS ... QUE TIVERAM A IDÉIADE CRIAR A FUNDAÇÃO ... O [CONSELHEIRO 1] ATÉ HOJE SE MANTÉM PRESENTE NA LIDERANÇA DA ORGANIZAÇÃO ... HOJE ELE É PRESIDENTE DO CONSELHO ... ELE SEMPRE FOI PRESIDENTE DE ALGUMA COISA

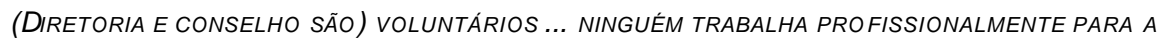
FUNDAÇÃO

O CONSELHO CONSULTIVO ... FOI CRIADO COMO UM ESPAÇO DE ASSESSORAMENTO ... FICOU SENDO UM ESPAÇO ONDE A GENTE COLOCAVA A MOBILIZAÇÃO DE PESSOAS DA SOCIEDADE CIVIL ... QUE QUERIAM PARTICIPAR DESTE MOVIMENTO QUE A FUNDAÇÃO SIGNIFICAVA ...

O CONSELHO DE ADMINISTRAÇÃO TEVE SEMPRE UMA PREDOMINÂNCIA MASCULINA E O PERFIL DO CONSELHO DE ADMINISTRAÇÃO É EMPRESARIAL

O CONSELHO CONSULTIVO ... TEM UMA PREDOMINÂNCIA DE MULHERES E A SUA LIDERANÇA SEMPRE FOI FEMININA

O CONSELHO CONSULTIVO, ESSA QUESTÃo DO SEM LIMITE DE NÚMERO É UM PROBLEMA, EU NÃO RECOMENDO ...

TODO MUNDO ... (TEM MÉDIA DE IDADE DE) 50 ANOS

No COMEÇO, DURANTE MUITO TEMPO, SE REUNIA MENSALMENTE O CONSELHO... NO ANO PASSADO A GENTE COMEÇOU A ESPAÇAR AS REUNIÕES ... AGORA ... O CONSELHO FOI ELEITO EM AGOSTO DE 2000 ... A PROPOSTA PARA ESTE CONSELHO AGORA É DE REUNIÕES TRIMESTRAIS, QUATRO REUNIÕES NO ANO ...

NA HISTÓRIA DA FUNDAÇÃO TEVE FASES EM QUE O CONSELHO CONSULTIVO SE REUNIA JUNTO COM O CONSELHO DE ADMINISTRAÇÃO, UMA VEZ POR MÊS; DEPOIS TEVE UM PERÍODO EM QUE AS REUNIÕES NÃO ACONTECIAM; DEPOIS TEVE REUNIÕES DO CONSELHO CONSULTIVO QUE O CONSELHO DE ADMINISTRAÇÃO ASSISTIA ... AGORA ... UMA FASE DE FORMALIZAÇÃO DA ORGANIZAÇÃO COMO UM TODO

Do LADO DO CONSELHO, A GENTE PROPÕE QUE ELE SE REUNA DE TRÊS EM TRÊS MESES, DUAS DESSAS REUNIÕES SÃO ORDINÁRIAS ... TÊM A VER COM ESTATU TO ... NA REUNIÃO DE DEZEMBRO O CONSELHO APRECIA A PROPOSTA DE PLANEJAMENTO E PREVISÃO ORÇAM ENTÁRIA PARA O ANO SEGUINTE, NA REUNIÃO DE MARÇO ELE APROVA O BALANÇO FINANCEIRO E O RELATÓRIO DE ATIVIDADES DO ANO ANTERIOR

(UMA REUNIÃO DEMORA) 2 HORAS ... ELES ESTÃO ACHANDO QUE DÁ, EU TAMBÉM ACHO QUE NÃO DÁ ... AS REUNIÕES DO CONSELHO NÃO SÃO BOAS, A GENTE AINDA NÃO CHEGOU NO PONTO

O conselheiro complementa: 
O TRABALHO EXECUTIVO DA FUNDAÇÃO DEMANDA HOJE MUITO TEMPO ... O PRESIDENTE É MUITO DEMANDADO, NÃO SÓ DO PONTO DE VISTA DE FAZER A GESTÃO INTERNA QUER DIZER, COORDENAR O GRUPO PROFISSIONAL ... QUANTO A PARTE DE COORDENAÇÃO EXTERNA ... NEGOCIAR COM PARCEIROS ... QUE EXIGEM QUE O PRESIDENTE ESTEJA PRESENTE ... QUANTO FAZER REPRESENTAÇÃO EM EVENTOS E SEMINÁRIOS ... É UM CARGO VOLUNTÁRIO QUE EXIGE MUITO TEMPO, NÃO É UM CARGO VOLUNTÁRIO QUE PODE SER EXECUTADO COM MEO PERÍODO POR SEMANA

EU PARTICIPO DE REUNIÕES DO CONSELHO DE ADMINISTRAÇÃO, PARTICIPO DE ALGUMAS REUNIÕES EXTERNAS...

Pelo fato de SER CONSELHEIRO - EU OCUPO O CARGo dE SECRETÁrIO do CONSELHO - PARTICIPO POR EXEMPLO dO COMITÉ JULGAdOR do PRÊMIO CRIANÇA ... PARTICIPO dE UMA REU NIÃo, QUE É CHAMADA REUNIÃO DO GRUPO EXECUTIVO DA FUNDAÇÃO, QUE ÉUMA REUNIÃO MENSAL DE 2-2,5 HORAS ... QUE REÚNE O PRESIDENTE DO CONSELHO, O SECRETÁRIO DO CONSELHO, A DIRETORIA, A SUPERINTENDÊNCIA E AS GERÊNCIAS DA FUNDAÇÃO ... UM GRUPINHO HOJE MEIO PESADO

A [Entidade 8] tem, portanto, uma influência empresarial, que é valorizada simbólica e funcionalmente pela inclusão de empresários no Conselho de Administração. A própria denominação "Conselho de Administração", trazida do meio empresarial, parece refletir essa influência. Além disso, nota-se nesta instituição a presença ainda forte de uma liderança fundadora, como se pode perceber pelos comentários:

O [CONSELHEIRO 1] ATÉ HOJE SE MANTÉM PRESENTE NA LIDERANÇA DA ORGANIZAÇÃO ... É TAMBÉM O IDEALIZADOR DA FUNDAÇÃO, CRIOU A FundAÇÃO ... E ATÉ HOJE É A SUA FIGURA DE PROA

\subsubsection{O Papel do Conselho nos Incidentes Críticos}

Os entrevistados desta instituição preferiram descrever a evolução da instituição, ao invés de incidentes específicos. Estas descrições são sintetizadas abaixo:

a) Mudança do papel do conselho. O conselho da Entidade 8 começou tratando de assuntos bastante operacionais, sob uma liderança forte do seu principal fundador, dirigindo uma organização de tamanho reduzido; com o passar do tempo houve um rápido crescimento institucional, ampliação da equipe técnica e necessidade de maior representação social e independência, levando o conselho a rever sua forma de trabalho e renovar seu quadro.

O CONSELHO DA FundaÇÃo QUANDO EU ENTREI ERA QUASE UMA DIRETORIA ... ISSO EU ESTOU FALANDO DE 1992 A 1994, $1995 \ldots$

NA ÉPOCA TINHA 10, 15 PESSOAS tRABalHANDO LÁ, hOJE TEM 70 ... O GRUPO PROFISSIONAL, QUE GERIA A FUNDAÇÃO NA ÉPOCA, ERA UM GRUPO COM EXPERIÊNCIA DE AÇÃO SOCIAL ... ACOSTUMADAS A OPERAR UM PROJETO DO PONTO DE VISTA DE ESTAR LÁ NA LINHA DE FRENTE, MAS NÃO DE SER ADMINISTRADOR DEUMA ORGANIZAÇÃO

A diREtoria da Fundação, que ERA ESSENCIALMENTE o[CONSELHEIRO 1] ... NEM ME LEMBRO QUEM ERA O RESTO DA DIRETORIA NA OCASIÃO ...

A CRIAÇÃO DE PROJETOS, A DECISÃO SOBRE APLICAÇÃO DE RECURSOS, DECISÕES BASTANTE OPERACIONAIS, ERAM LEVADAS AO CONSELHO DE ADMINIS TRAÇÃO, PORQUE HAVIA MUITOU M PARTILHAR DAS COISAS, O CONSELHO TOMAVA MUITO ESSAS DECISÕES ...

QUANDO EU ASSUMI A PR ESIDÊNCIA DO CONSELHO DE ADMINISTRAÇÃO, QUE FOI EM 1996, ... A FUNDAÇÃO JÁ ERA MUITO MAIOR, ELA JÁ TINHA MAIS PROJETOS, CRIANDO FRENTES DE ATUAÇÃO... 
COMEÇOU A FICAR CLARO QUE HAVIA UMA SÉRIE DE QUESTÕES OPERACIONAIS QUE NÃO SE PODIA MAIS LEVAR AO CONSEL HO DE ADMINISTRAÇÃO, NÃO FAZIA MAIS SENTIDO ... O CONSELHO DE ADMINISTRAÇÃO COMEÇOU A ASSUMIR UMA QUESTÃO MAIS ESTRATÉGICA E MENOS OPERACIONAL ... ESSA TRANSIÇÃO FOI MUITO DIFÍCIL E ELA ... CONTINUA SENDO TRABALHADA ... PARA ALGUMAS PESSOAS QUE ERAM DO CONSELHO ANTERIORMENTE, O CONSELHO FICOU MEIO VAZIO ... AS QUESTÕES ERAM MEIO GENÉRICAS E A DIRETORIA TINHA UMA CERTA DIFICULDADE DE COLOCAR QUESTÕES ESTRATÉGICAS PARA O CONSELHO DE ADMINISTRAÇÃO ... APRESENTAVAM, FAZIAM UM RELATO E AS PESSOAS COMEÇAVAM A SE SENTIR UM POUCO DESESTIMULADAS ... ESSE É UM PROCESSO QUE A FUNDAÇÃO AINDA VIVE

Nos ÚlTIMOS 2 ANOS ... NÓS COMEÇAMOS A DESENVOLVER UM PROCESSO TODO DE PLANEJAMENTO ESTRATÉGICO ONDE SE ENVOLVEU PESADAMENTE O GRUPO PROFISSIONAL DAFUNDAÇÃO ... A SUPERINTENDENTE, GERENTES E COORDENADORES ... QUE MERGULHARAM A FUNDO EM PENSAR COMO A FUNDAÇÃO DEVERIA SER 2 ANOS PARA FRENTE ... E AÍ A SUSCITAR QUESTÕES PARA O CONSELHO DE ADMINISTRAÇÃO

AO MESMO TEMPO NÓS ... COMEÇAMOS A PROCURAR LEVAR AO CONSELHO DE ADMINISTRAÇÃO PESSOAS COM GRANDE EXPERIÊNCIA NA ÁREA ... QUE IAM LÁ FALAR SOBRE ALGUM TEMA ...PARA PROCURAR EDUCAR ESTE CONSELHO EM ALGUMAS DAS QUESTÕES SUBSTANCIAIS DE CONTEÚ DO ... MUITO DOS EMPRESÁRIOS TÊM UMA VISÃO SOCI AL, MAS TÊM UMA VISÃO DI STANTE DA QUESTÃO MAIS TÉCNICA

ISSO ... LEVOU O CONSELHO DE ADMINISTRAÇÃO NO FIM, MUITO CONDUZIDO PELO SEU PRESIDENTE ... A FAZER UMA DEFINIÇÃO M AIS CLARA ... DOS RUMOS QUE A FUNDAÇÃO DEVERIA TOMAR ...

AO LONGO DESSE PROCESSO VÁRIOS CONSELHEIROS SE SENTIRAM DESESTIMULADOS ... NÃO CONSEGUIAM PROPRIAMENTE ACOMPANHAR ESSA DISCUSSÃO CONCEITUAL ... MUITA GENTE FALTOU MUITAS VEZES, NÓS TIVEMOS MUITAS REUNIÕES DE CONSELHO COM POUCOS CONSELHEIROS PRESENTES ... MANIFESTARAM CLARAMENTE ... QUANDO SE DISCUTIU RENOVAÇÃO ... QUE "EU NÃO ME SINTO ÚTIL; EU VENHO AQUI, EU OUÇO, MAS EU CONTRIBUO COM MUITO POUCO"

NO MOMENTO ESTÁ HAVENDO UMA REVIRAVOLTA DISSO ... NOVAS PESSOAS PASSARAM A FAZER PARTE DO CONSELHO ... PARTICIPARAM DE ALGUNS ENCONTROS PARA ENTENDER UM POUCO O QUE É A FundAÇÃO ... VAMOS TER UMA NOVA REUNIÃO AGORA EM DEZEMBRO DE 2000 ... NESTE MOMENTO O PAPEL DO DIRETOR PRESIDENTE DA FUNDAÇÃO ESTÁ SENDO MUITO IMPORTANTE PARA ISSO ... ESTÁ PODENDO DEDICAR BASTANTE TEMPO, É UMA PESSOA DE VISÃO ORGANIZACIONAL MUI TO BOA, CONDUTOR DE PROCESSOS ... ESTÁ NÃO SÓ ENVOLVEN DO CONSELHEIROS, COMO FAZENDO UMA INTEGRAÇÃO DE CONSELHEIROS ... E ENVOLVENDO TAMBÉM O GRUPO EXECUTIVO, O GRUPO PROFISSIONAL DA FUNDAÇÃO NESSE PROCESSO

ESSE PROCESSO COM SUAS IDAS E VINDAS ... ACABOU RESULTANDO NUMA FORMA ESTRUTURADA DE COLOCAR AS QUESTÕES PARA O CONSELHO DE ADMINISTRAÇÃO ... AJUDOU A LEVAR O CONSELHO A PODER DISCERNIR ALGUMAS DESSAS QUESTÕES ... CONSEGUIR COLOCAR AS QUESTÕES DE FORMA CLARA PARA O CONSELHO ... LEVOU A ESSA DEFINIÇÃO MAIS CLARA DE QUE NÓS VAMOS INFLUENCIAR POLÍTICAS PÚBLICAS, NÓS VAMOS LIDAR COM ORÇAMENTO, NÓS VAMOS REFREAR ESSE IMPULSO DE CRESCER E SE EXPANDIR..

Este caso trata da mudança de papel do Conselho, de um nível mais operacional para um nível mais estratégico, num processo de transição, ainda em andamento aparentemente, que tem sido um desafio para as lideranças do conselho e da diretoria. Pelos comentários do conselheiro, a mudança de papel é 
favorecida pela disposição do conselho em se educar, pela atitude educacional das lideranças, pela entrada de pessoas mais distantes do diaa-dia e da história da organização, pela capacidade da equipe técnica em desenvolver-se no campo da gestão. A diretoria também teve que rever sua forma de trabalho, deixando de apresentar resultados operacionais para formular questões estratégicas. Uma medida importante nessa direção foi o desencadear de um processo formal de planejamento estratégico. Outro passo importante, intencional ou circunstancial, foi conseguir um diretor presidente dedicando-se mais intensivamente à integração entre os diferentes grupos organizacionais. Finalmente, a presença de lideranças determinadas fez $œ m$ que fosse possível suportar reuniões com poucas pessoas e muita incerteza pessoal, assumindo responsabilidade por conduzir as reuniões e dar comentários e diretrizes àequipe executiva.

Outros desafios podem ser observados neste caso: (a) a diferença entre a cultura institucional, de caráter mais social, e a cultura da maioria dos conselheiros, mais empresarial; (b) a pouca formação da equipe executiva em gestão; (c) a demanda da sociedade; (d) a expansão do corpo profissional.

As lideranças do conselho tiveram a preocupação, aparentemente, de cuidar de um processo através do qual pudesse ocorrer o desenvolvimento da Fundação, ao invés de trazer respostas prontas ou simplesmente pareceres e diretrizes. Desencadeou-se um processo em duas frentes: com a equipe operacional e com o conselho. A primeira, discutindo propostas e questões para os próximos 2 anos. O segundo, discutindo temas de relevância e definindo rumos. Parece ter havido muita habilidade das lideranças ao imaginar este processo e ao dispor-se a facilitá-lo.

b) Mudança de modelo organizacional. A Entidade 8 operou vários anos dentro de um modelo informal, visionário, flexível e articulador, com alto grau de autonomia e voltado para a realização - este modelo era muito determinado pela personalidade e estilo pessoal do seu principal fundador; com o crescimento institucional houve necessidade de uma maior formalização de papéis, responsabilidades e funções, que vem acontecendo nos últimos 2 anos, num processo difícil e tenso. $O$ conselho e a diretoria mudaram durante este período, estando num momento quase ausentes e no outro assumindo a liderança da formulação de um novo modelo de estrutura organizacional.

O INSTITUIDOR ... ESTEVE MUITO PRESENTE ... ELE IMPRIMIU UM MODEO MUITO PESSOAL DE GESTÃO

... ELE É UMA PESSOA VISIONÁRIA, MOBILIZADORA, CAPTADORA DE RECURSOS, ARTICULADOR POLITICO E ESSAS CARACTERÍSTICAS ... FEZ COM QUE MUITOS D OS PROJETOS ... VIESSEM DA PRÓPRIA INICIATIVA DELE ... ELE IMPRIMIU MUITO DO JEITO DA FUNDAÇÃO SER ... UM JEITO MUITO DESORGANIZADO DE SER

AS EQUIPES DOS PROJETOS FORAM DESENHANDO SEUS PROJETOS COM MUITA AUTONOMIA E FORAM IMPLEMENTANDO MUITA COISA ... FOI CRIANDO EQUIPES QUE SE SENTEM PARTE EVIDENTEMENTE, QUE NÃO ACEITAM O PAPEL DE MERO EXECUTOR

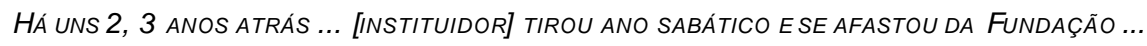
FICOU FORA UM ANO ... A GENTE ESTAVA CRESCENDO, ENTRANDO GENTE NOVA ... O ASSUNTO DE GESTÃO COMEÇOU A APARECER

DEPOIS O [INSTITUIDOR] VOLTOU E DISSE QUE TINHA PLANOS DE FUTURO OUTROS, NÃO QUERIA MAS ESTAR NO DIA-A-DIA DA FUNDAÇÃO ... [CONSELHEIRO] ASSUMIU A PRESIDÊNCIA EXECUTIVA ... FOI UMA PRESIDÊNCIA MUITO IMPORTANTE NO SENTIDO DE TER FEITO A UM ESTILO DE RELACIONAMEN TO COM OS PROFISSIONAIS DIFERENTES ... NO MEIO DESSE MANDATO ELE ASSUMIU A PRESIDÊNCIA [DE OUTRA ENTIDADE] ... 
ESTÁVAMOS NUMA FASE DE TRANSIÇÃO IMPORTAN TE ... OUTUBRO DE 1998 COMEÇAMOS UMA REVISÃO DE MODELO ORGANIZACIONAL, REVISÃO DE MISSÃO ... ENVOLVEMOS OS CONSELHOS ... EM FEVEREIRO DE 1999 NÓS COMEÇAMOS UM TRABALHO DE DETALHAMENTO DISSO COM O STAFF... E NESSE MOMENTO O [CONSELHEIRO] ME INFORMA QUE ESTAVA ACEITANDO A PRESIDÊNCIA DA [OUTRA ENTIDADE] $\ldots$

NÃO TIVEMOS A DIRETORIA MOBILIZADA NESSE PERÍODO ... A DIRETORIA NA GESTÃO PASSADA ERA O [CONSELHEIRO], O ... VICE, E O ... TESOUREIRO, QUE ... SEMPRE ABRIU MÃO ... O [VICE] ... NUNCA VEIO... ESTAVA CRIANDO UMA UNIVERSIDADE ... PORQUE HOMENS DE NEGÓCIOS, SE ELES ESTÃO NA ATIVA, ELES ESTÃO OCUPADÍSSIMOS

O[VICA ESTEVE AQUI NA PRIM日RA REUNIÃO; ... ELE MANDOU CONSULTORES ... TRABALHAREM COM A GENTE

ENTÃO A DIRETORIA, NA GESTÃO PASSADA, ERA UMA DIRETORIA QUE TINHA O[CONSELHEIRO] NA VERDADE ...

NA VERDADE AS LIDERAN ÇAS EMPRESARIAIS ESTAVAM DIZENDO: "TOQUEM A FUNDAÇÃO" E ENTREGANDO ... PARA UM GRUPO DE PROFISSIONAIS SEM EXPERIÊNCIAS DE GESTORES

ESSE PROCESSO DE REVISÃO DA ORGANIZAÇÃO E DO MODELO DE GESTÃO ELE FOI LONGO, MUITO LONGO ... NÃO TEVE UMA BOA LIDERANÇA, NÃO TEVE UMA BOA COORDENAÇÃO, A GENTE SOFREU MUITO, SE PERDEU MUITO...

ESSE ANO DE 2000, PRIMEIRO SEMESTRE, ELE FOI TODO VOLTADO A IMPLANTAR ESSE MODELO COM AS GERÊNCIAS... NESSE PRIMEIRO SEMESTRE ERA O PERÍODO DE CONCRETIZAR AS GERÊNCIAS ... E A GENTE BRIGOU MUITO, FOI MUITO DIFICIL, QUASE QUE IMPLODIU

O [NOVO DIRETOR PRESIDENTE] ENTROU EM AGOSTO RECEBENDO ESSA SITUAÇÃO DA ORGANIZAÇÃO, OU SEJA, UMA ORGANIZAÇÃO QUE ESTÁ TENTANDO CRIAR UM NOVO MODELO DE GESTÃO, UMA NOVA VISÃO, COM MUITA DIFICULDAD E DE ENXERGAR À DISTÂNCIA, ENXERGAR ESTRATÉGIAS, DE LIDERAR A ORGANIZAÇÃO ... OS TRABALHADORES BRAVOS TAMBÉM ... CRIAMOS UM NOVO MODEO, MAS NINGUÉM SABE COM QUEM FALAR, NINGUÉM SABE QUEM DECIDE O QUÊ, UM DECIDE DE UM JEITO, OUTRO DECIDE DE OUTRO, UM JOGA PARA UM, OUTRO JOGA PARA OUTRO ... A GENTE SOFREU E PER DEU PRODUTIVIDADE PROVAVELMENTE

O [NOVO DIRETOR PRESIDENTE] ENTROU E ESSA NOVA DIRETORIA ENTROU PARA VALER ... (ELE) VOLTA A OFERECER QUATRO PERÍODOS NA SEMANA PARA A FUNDAÇÃO ...

O CONSELHO SE REUNIA ... NESSE MEIO TEMPO ELE DISCUTIU AS MUDANÇAS DA VISÃO ESTRATÉGICA DA FUNDAÇÃO ... FEZ UM BALANÇO NO FI NAL DO ANO PASSADO ... UM BALANÇO DE MUITA FRUSTRAÇÃO ... TÍNHAMOS 10 ANOS ... A DECISÃO FOI QUE NÓS NÃO PODEMOS COMEMORAR ... A SITUAÇÃO DA INFÂNCIA CONTINUA RUIM ... A GENTE NÃO ESTÁ CONSEGUINDO ENFRENTAR OS PROBLEMAS ... CHEGOU-SE À CONCLUSÃO DE QUE ... A POLÍTICA PÚBLICA É QUE GERA UNIVERSALIZAÇÃO E O MODELO ECONÔMICO É O QUE GERA OS PROBLEM AS ... E GOVERNOS QUE NÃO DÃO CONTA DA SUA PAR TE ... NÓS PRECISAMOS OLHAR PARA O GOVERNO ... PARA QUE ELE FAÇA A PARTE DELE

ISSO VEIO ACONTECENDO SEMPRE EM REUNIÕES DE 2 HORAS ... ESSA DISCUSSÃO DEVE TER TIDO UMAS 3 A 4 REUNIÕES ... NO COMEÇO DESTE ANO A GENTE FEZ REUNIÕES JUNTAS, DO CONSELHO DE ADMINISTRAÇÃO COM O CONSELHO CONSULTIVO...

O CONSELHO ... REVIU A MISSÃO, REVIU A VISÃO, REVIU VALORES ... ELES FALARAM, O CORPO PROFISSIONAL FALOU, NÓS VOLTAMOS PARA ELES, ELES APROVARAM OU ELES MUDARAM ... FOI UM VAI 
E VEM ... ESSAS DISCUSSÕES SOBRE VISÃO ESTRATÉGIA E POLÍTICAS PÚBLICAS ESTÃO DESDE 1998 ... COMO A GENTE FEZ 10 ANOS, PUXOU ESSA CONVERSA: COMEMORA OU NÃO COMEMORA? ... FEZ COM que A GENTE SELECIONASSE ... O FOCO NA POLÍTICA PÚBLICA E ... ORÇAMENTO PÚBLICO E EDUCAÇÃO COMO TEMAS QUE O CONSELHO TROUXE COMO IMPORTANTES

COM A ENTRADA DO [NOVO DIRETOR PRESIDENTE] FICOU ASSIM: SEM O GRUPO GESTOR, O [NOVO DIRETOR PRESIDENTE] TEM ASSISTIDO ÀS REUNIÕES DO GRUPO GESTOR E NAS REUNIÕES DO GRUPO DIRETOR O GRUPO GESTOR PARTICIPA TAMBÉM ... EU NÃO SEI A SUPERINTENDÊNCIA A QUE INSTÂNCIA ELA FAZ PARTE ... O QUE FICOU MUITO CLARO É QUE É SUPER -IMPORTANTE MANTER A HIERARQUIA, AS FUNÇÕES E AS RESPONSABILIDADES

ESSE MODELO QUE A GEN TE CRIOU É O MODELO MATRICIAL DE GERÊNCIAS, MAS QUE OS PROJETOS SÃO POSTOS NO MEIO DESSE MODELO ... SE ORGANIZA POR PROG RAMAS, QUE REFLETEM ESTRATÉGIAS E TUDO QUE FAZEMOS TEM QUE SER PENSADO...

AS GERÊNCIAS QUE A GENTE CONSTITUIU SÃO GERÊNCIAS QUE REFLETEM ESTAS VISÕES ... MOBILIZAÇÃO SOCIAL ... ARTICULAÇÃO POLÍTICA ... COMUNICAÇÃO ... PROJETOS ... DESENVOLVIMENTO INSTITUCIONAL

O caso descrito acima referese:

- $\quad$ àredefinição de papéis dentro da organização;

- àimplantação de uma nova estrutura organizacional;

- àredefinição estratégica da Fundação;

- àtransformação das lideranças técnicas em gestoras.

É um processo ainda em andamento, não totalmente consolidado, no qual tanto a equipe gestora, quanto a diretoria e o conselho tiveram papéis relevantes, com focos diferentes.

O conselho teve um foco estratégico, trabalhando a partir da pergunta "comemora ou não comemora?". Os gestores estavam preocupados com "assuntos mais administrativos, começar a pensar em cargos e salários, começar a pensar perfil de cargos". E a diretoria "entendeu que a Fundação está precisando hoje de fazer um processo de formalização dos seus relacionamentos".

O processo foi dificultado porque "Não tivemos a diretoria mobilizada nesse período" ... "e que na verdade as Ideranças empresariais estavam dizendo: "toquem a Fundação"'. A ponto da executiva concluir: "eu acho fundamental ter uma diretoria executiva próxima e presente".

A organização passava por uma crise, motivada tanto pelo crescimento significativo, quanto pela avaliação de resultados de 10 anos de trabalho. Integrar as duas questões era um desafio complexo, enfrentado com dificuldade pela equipe de gestores, com apoio irregular da diretoria. Estes dois fatores levaram a uma revisão do modelo anterior, baseado em uma liderança carismática, centralizada, muito presente e num estilo informal de trabalho. Exige-se agora relações mais formalizadas, definição clara de papéis e objetivos, bem como procedimentos e estruturas que permitam que o todo trabalhe de forma integrada. O conselho é chamado a um papel mais estratégico, a equipe técnica precisa desenvolver maior capacidade de gestão e a diretoria precisa operar para garantir a integração e coordenação entre ambos.

A superintendente acabou sendo bastante sacrificada pela ausência da diretoria, como demonstram os comentários: 
EU NÃO ME RELACIONO FORMALMENTE COM ELES ... NÃO PREPARO DOCUMENTOS ... EU AINDA NÃO CONSEGUI POR A RELAÇ ÃO COM OS CONSELHEIROS NO MEU COTIDIANO ... NÃO TENHO MAPA/PERFIL DOS CONSELHEIROS ... PRECISA TER UM PLANO DE AÇÃO E TRABALHAR COM ELES ...

EU AINDA ESTOU MUITO OCUPADA COM A GESTÃO, COM RECURSOS HUMANOS, COM AS PESSOAS, COM ORIENTAÇÃO NO DIA-A-DIA ... COM NORMAS ... A GESTÃO PARA DENTRO DA ORGANIZAÇÃO AIND A ME OCUPA MUITO ... A IDÉIA ERA QUE EU DEIXASSE DE MEOCUPAR COM ELA ... MAS EU AINDA NÃO ESTOU CONSEGUINDO

A narrativa da Entidade 8 é muito rica para ilustrar o processo de diferenciação discutido na Terceira Parte deste trabalho. Ao ser perguntada sobre por que ter diretoria e conselho, depois de todas essas experiências, a superintendente respondeu:

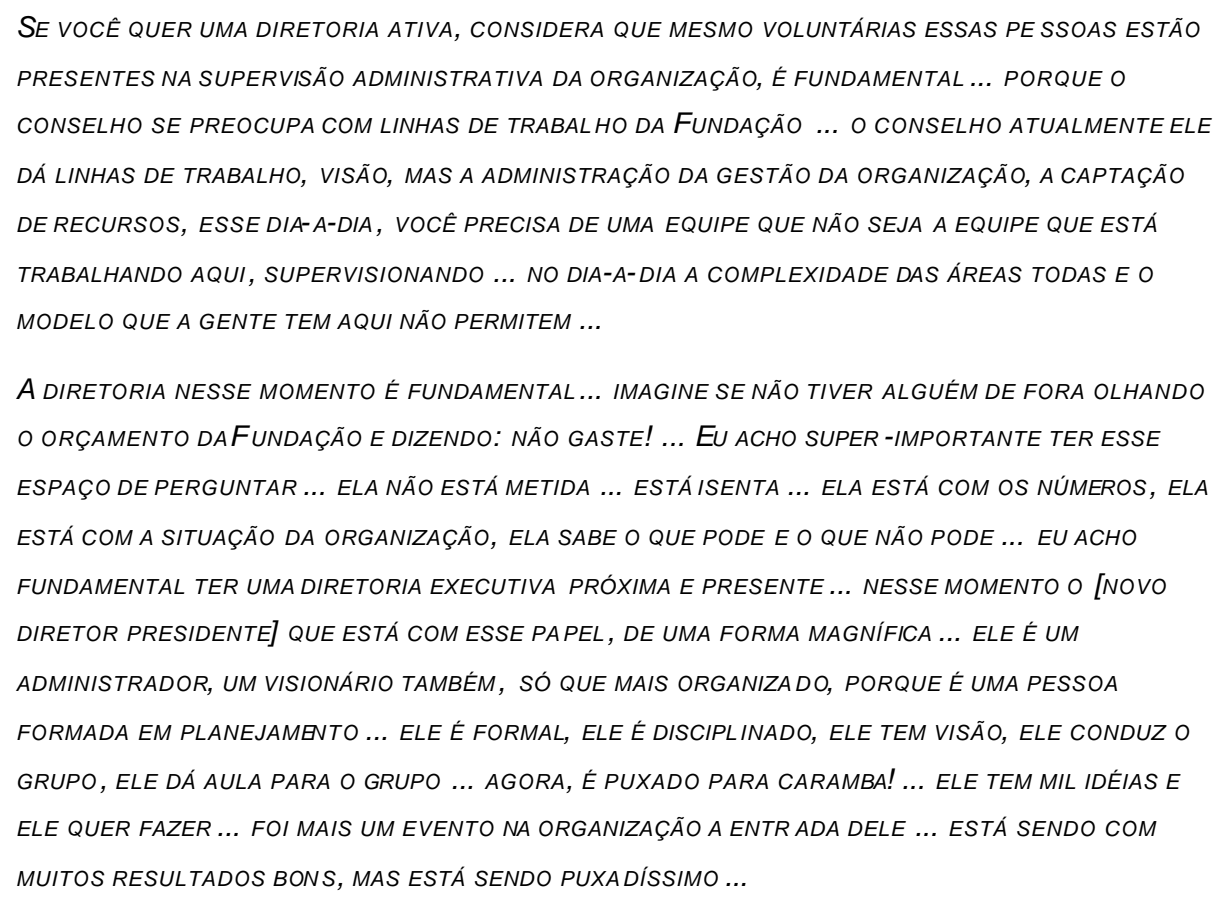

As entrevistam revelam que a Fundação está num processo avançado de diferenciação entre os três principais grupos que governam a instituição:

1. O conselho de administração, que está assumindo um papel caracteristicamente estratégico;

2. A equipe técnica e administrativa, encarregada dos aspectos operacionais;

3. A diretoria, responsável por manter uma integração saudável na instituição.

O conselho de administração, criado nos moldes de uma empresa privada, vinha se envolvendo em vários assuntos ligados à administração da organização, especialmente aqueles de cunho administrativo e simbólico (representação). Historicamente tem sido influenciado pelo grupo fundador, especialmente pelo líder deste grupo. Este grupo fundador aparentemente assumia posições no conselho ou na diretoria em função das exigências e possibilidades pessoais do momento - havia um revezamento nas posições formais, como denota a fala do conselheiro entrevistado: "desde meados de 1992 participo da Fundação, alternadamente como conselheiro, diretor, conselheiro, presidente e agora de novo conselheiro". Essa alternância, bem como a pouca freqüência de alguns diretores em seus cargos, indica que o governo da 
Fundação era realmente feito pelo grupo fundador. Com o aumento da demanda, o crescimento da organização e a tomada de consciência dos resultados alcançados em 10 anos está havendo a necessidade de uma diferenciação entre os três papéis citados acima.

\subsubsection{Competêncheias desenvolvoldasas}

A avaliação das competências do grupo dirigente da Entidade 8 pode, mais uma vez, ser feita sob diferentes pontos de vista:

Dimensão Analítica: nos casos descritos foram adotadas algumas medidas pelos conselheiros e diretores que denotam um grau significativo de competência analítica. Por exemplo: a iniciativa de trazer especialistas de fora para discutir com os conselheiros sobre temas específicos representa um esforço em examinar diferentes pontos de vista e dissecar os assuntos; o uso de questões, como "comemorar ou não comemorar?"; e o convite para que a equipe gestora participasse de algumas das reuniões. O grau de detalhamento e abrangência do raciocínio a respeito da estratégia institucional também reflete um bom grau de competência analítica.

Dimensão contextual: o conselho de administração enquanto preenchido pelos fundadores conhece muito bem a Fundação, sua história e seus valores. Foi responsável pela estruturação programática da Fundação até recentemente, inclusive desenhando projetos. Entretanto, a entrada de novos membros já está gerando insegurança, a ponto do conselheiro entrevistado não ter ainda identificado uma pessoa para substitui-lo em um dos programas: "eu estou tentando passar o bastão, mas está meio difícil ... é uma questão de continuidade do programa, de conceitos, de história que fica meio difícil de passar a bola”. Isto está merecendo atenção (formal) do conselho e da diretoria, conforme explicitado nos seguintes comentários:

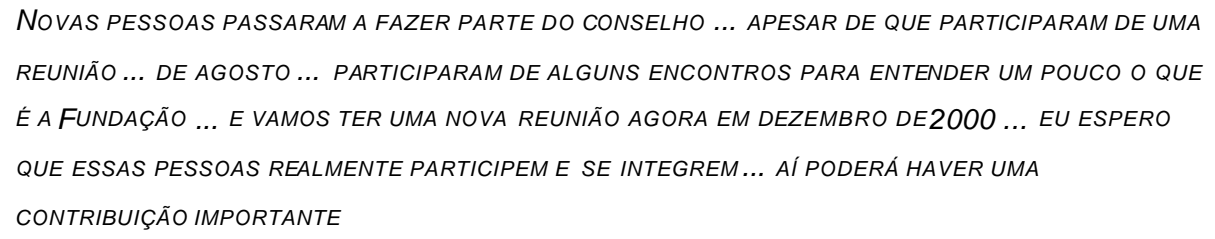

Competência educacional: este conselho tomou iniciativas bem concretas no sentido educacional dos seus membros; foram elas: discussões com especialistas externos, reuniões sobre a fundação e eventualmente um trabalho mais individualizado em comitês, além de colocar o conselho em contato, nas reuniões, com a equipe gestora.

ESSE É UM PROCESSO MUITO DIFÍCIL, ELE EXIGE UMA DOSE DE FLEXIBILIDADE, PORQUE VOCÊ TRAZ CONSELHEIROS QUE NÃO TÊM UMA VISÃO COTIDIANA DO PROBLEMA ... É MUITO DIFERENTE DEUM CONSELHEIRO EMPRESARIAL, DE UM CONSELHEIRO DE UMA EMPRESA... O CONSELHEIRO DE EMPRESA LIDA COM QUESTÕES EMPRESARIAIS EM OUTRAS EMPRESAS ... ELE TRATA DE QUESTÕES DE PRODUÇÃO, DE QUESTÕES DE MARKETING, DE QUESTÕES DE IMAGEM INSTITUCIONAL, ELE LIDA SEMPRE COM QUESTÕES DE ESTRATÉGIA EMPRESARIAL, ELE FALA AQUELA LINGUAGEM, ELE TRATA AQUELE PROBLEMA ... SE ELE É DE UMA EMPRESA E ESTÁ NO CONSEL HO DE OUTRA, ELE OLHA UM MERCADO DIFERENTE, UM PRODUTO OU SERVIÇO DIFERENTE ... ELA TRATA MAIS OU MENOS DOS MESMOS PROBLEMAS ... E QUANDO ELE VAI SER CONSELHEIRO DE UMA ENTIDADE SEM FINS LUCRATIVOS, ELE TRATA DE UMA GAMA COMPLETAMENTE DIFE RENTE DE PROBLEMAS, MAS AO MESMO TEMPO ELE PRECISA CONTRIBUIR COM ESSA VISÃO DE COMO É QUE SE ENCARA UM MERCADO, DE 


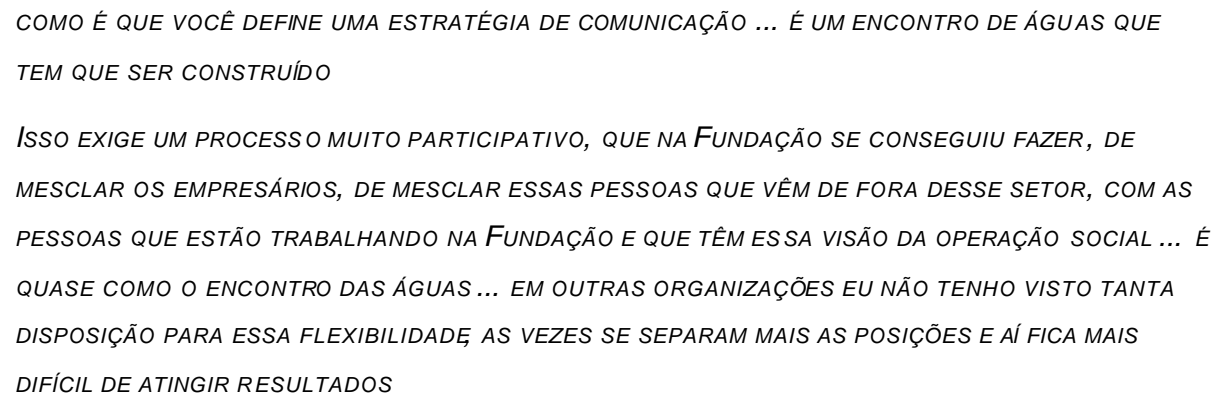

Competência estratégica: é, aparentemente, o ponto mais forte do conselho, alavancado pelo grupo fundador. O conselho soube transformar questões conjunturais em questões estratégicas ("comemorar ou não?'), bem como delinear claramente prioridades e diretrizes para a organização. Além disso, parece manter a maior parte do tempo o foco em resultados e em realizações, seja numa organização com estilo formal ou informal de trabalho.

Competência interpessoal: o conselho tem, aparentemente, alguma dificuldade de trabalhar como equipe, valorizando esforços individuais. A executiva faz uma crítica explícita nessa direção. O perfil "plural" do conselho cria um desafio nesta dimensão, pois formase um grupo heterogêneo. A forte influência do grupo fundador ambém indica que há bastante a ser feito nessa dimensão. Pelos comentários de que "o presidente especialmente, se ele pudesse compartilhar com o vice e com o diretor financeiro" e "eu estou tentando passar o bastão, mas está meio difícil", pode-se inferir que o processo sucessório e de formação de grupo ainda é um desafio para a Fundação.

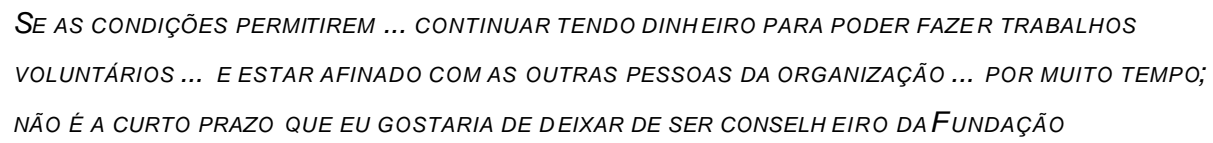

Competência política: a relação com a instituidora tem caráter político, demonstrando que o conselho está atento a isso. A preocupação em envolver e consultar a equipe executiva da fundação, a criação do conselho consultivo, a realização de reuniões abertas a conselheiros consultivos e a membros remunerados também. A Entidade 8 revela um bom grau de competência política ao preocupar-se com uma representação maior de pessoas "de fora" no seu conselho:

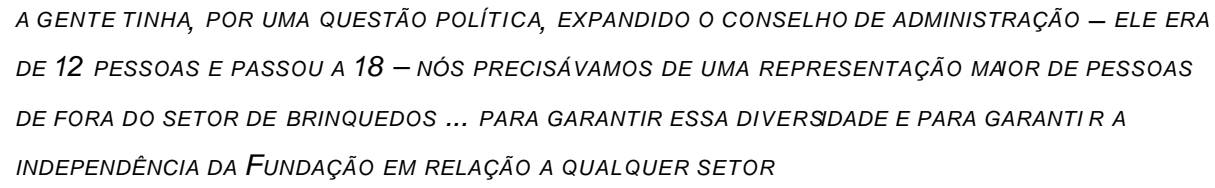

\subsubsection{ENTIDADE 9}

\subsubsection{Contexto institucional}

A Entidade 9, também uma fundação, foi criada há apenas dois anos e tem como missão "investir na formação de gerações de crianças e adolescentes capazes de transformar suas realidades, garantindo-lhes o direito à educação, cultura e assistência social". Está situada na zona norte da cidade de São Paulo. Surgiu da iniciativa de dois atletas profissionais, tendo quatro eixos de atuação: atendimento direto, desenvolvimento cultural, mobilização e desenvolvimento institucional. 
O patrimônio desta fundação constitui-se, segundo o estatuto, de: (a) dotação inicial destinada pelos instituidores, (b) quaisquer novas doações que vierem a ser efetivadas e (c) aquisições no exercício de suas atividades. Um dos instituidores reside fora do país, apesar de ser brasileiro, acompanhando as atividades da organização somente quando vem passar férias no Brasil.

A liderança executiva entrevistada é coordenadora de projetos; é formada em Letras, nascida em 1952 e exerce sua função de forma remunerada.

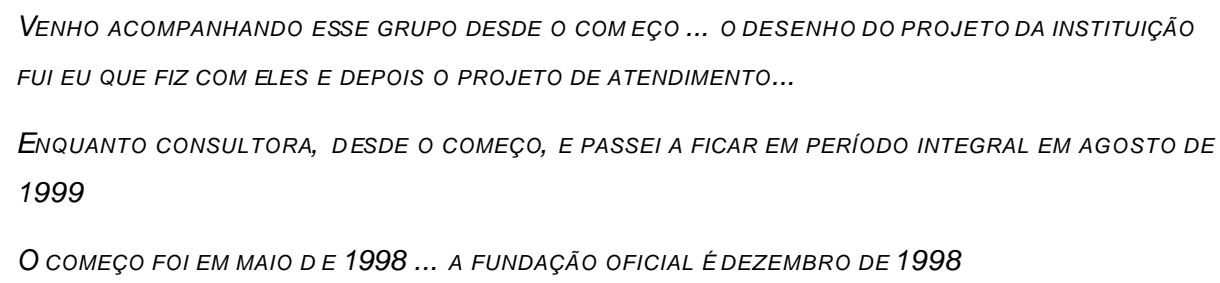

As principais atividades relacionadas àsua função, segundo ela, são:

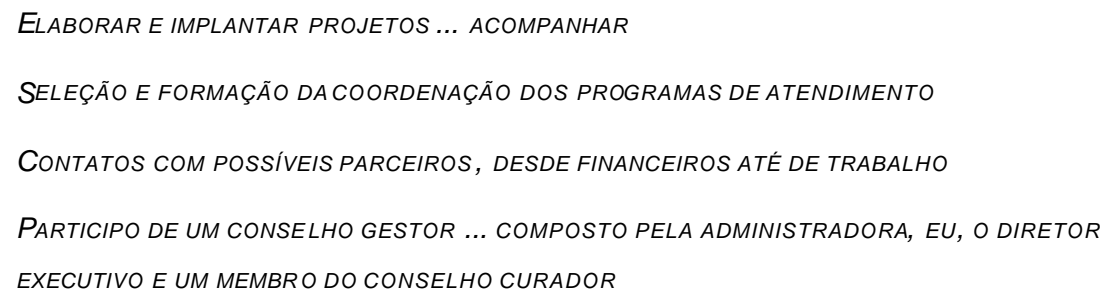

A liderança do conselho curador é o principal instituidor da entidade, sendo bastante jovem:

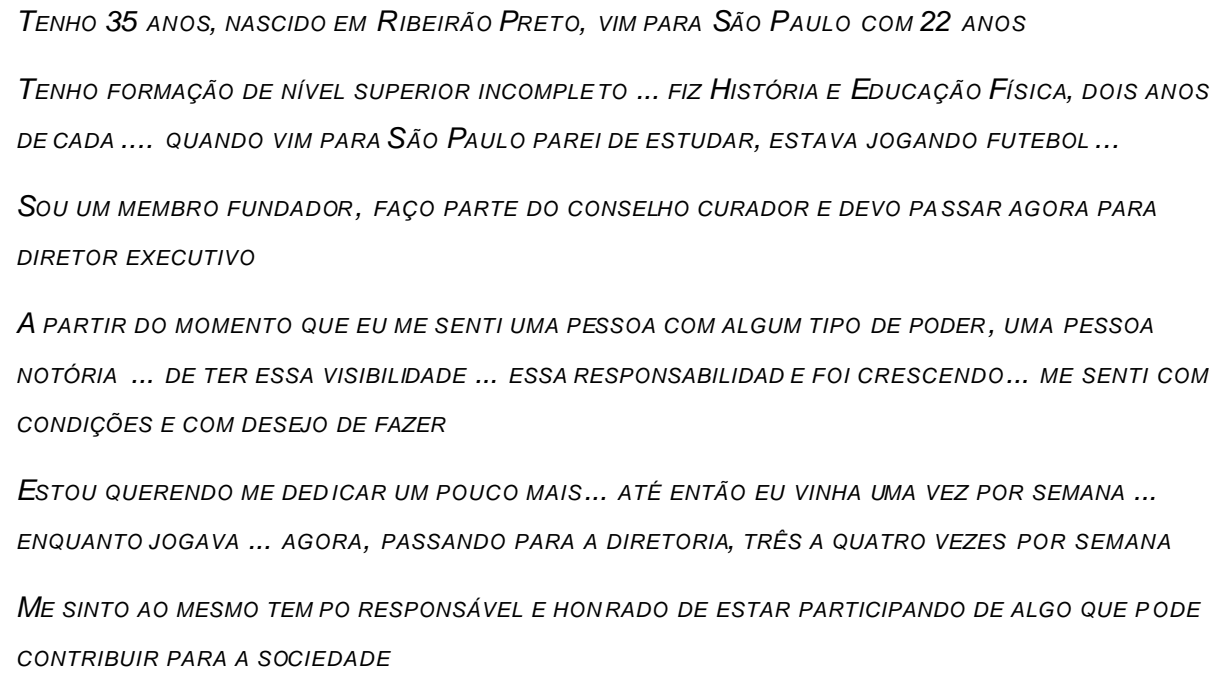

De acordo com o estatuto, a Fundação é administrada por um conselho curador, uma diretoria executiva e por um conselho consultivo. É vedado o exercício simultâneo dos cargos no conselho curador e na diretoria executiva, em qualquer hipótese. O conselho curador é constituído, "no papel", por 6 membros, sendo 4 efetivos e 2 suplentes, por indicação dos membros do conselho, com mandato de 2 anos, permitida a recondução. Compete ao conselho curador:

I. Eleger os membros da diretoria executiva;

II. Aprovar a previsão orçamentária e o plano anual de ação propostos pela diretoria executiva; 
III. Estabelecer diretrizes de ação para a diretoria executiva;

IV. Aprovar as prestações de contas e os relatórios anuais da diretoria executiva;

V. Deliberar sobre a alienação de bens patrimoniais;

VI. Editar seu regimento interno;

VII. Alterar o estatuto.

A diretoria executiva é constituída por 3 membros, eleitos pelo conselho curador por 3 anos. A diretoria executiva é responsável por administrar a Fundação, obedecendo às diretrizes fixadas pelo conselho curador. Na prática existe ainda um grupo gestor, conforme o depoimento da executiva:

(CONSEL ho CURAdor) SÃo 4 MEMBROS E dOIS SUPLENTES (INCLUI O DIRETOR EXECUTIVO) ... NÃO SE REÚNE REALMENTE

DIRETORIA EXECUTIVA É FORMADA POR 3 MEMBROS

GRUPO GESTOR SÃO DOIS TÉCNICOS... DA ÁREA ADMINISTRATI VA E COORDENAÇÃO DE PROJETOS, O DIRETOR EXECUTIVO E UM MEMBRO DO CONSELHO CURADOR

OS CONSELHEIROS SÃO FAMILIARES E AMIGOS DOS INSTITUIDORES ... TEM HOMENS E MULHERES ... SEM EXPERIÊNCIA NA ÁREA DE PROJETOS SOCIAIS, NEM EMPRESAS ... UM DELES, QUE PARTICIPA

DESSE GRUPO GESTOR ... TEM EXPERIÊNCIA, TRABALHOU EM UMA FUNDAÇÃO DE TRABALHADORES ... TEM ENVOLVIMENTO MAIOR E EXPERIÊNCIA EM ADMINISTRAÇÃO, APESAR DE SER ENGENHEIRO ... IDADE MÉDIA 35 ANOS

O CONSELHO GESTOR QUE ACOMPANHA O DIA-A-DIA

O conselheiro tem a seguinte imagem do grupo gestor:

(O PAPEL DO CONSELHO) NO SENTIDO DE CURAR ... DE ESTAR ACOMPANHANDO ... ESTAR PARTICIPANDO COM OPINIÕES ... ACOMPANHAMENTO DE PERTO PARA VERIFICAR SE ESTÁ INDO COMO IMAGINA

SOMOS QUATRO MAIS DOIS SUPLENTES ... ATIVOS SÃO OS TRÊS PRIMEIROS ... (REUNIÕES) ESTE ANO ... DUAS VEZES NESTE SEGUNDO SEMESTRE ... FUI PARA A EUROPA E TEVE MAIS DUAS

Como principais lideranças da instituição, mantêm um bom relacionamento, de muita confiança e admiração mútua.

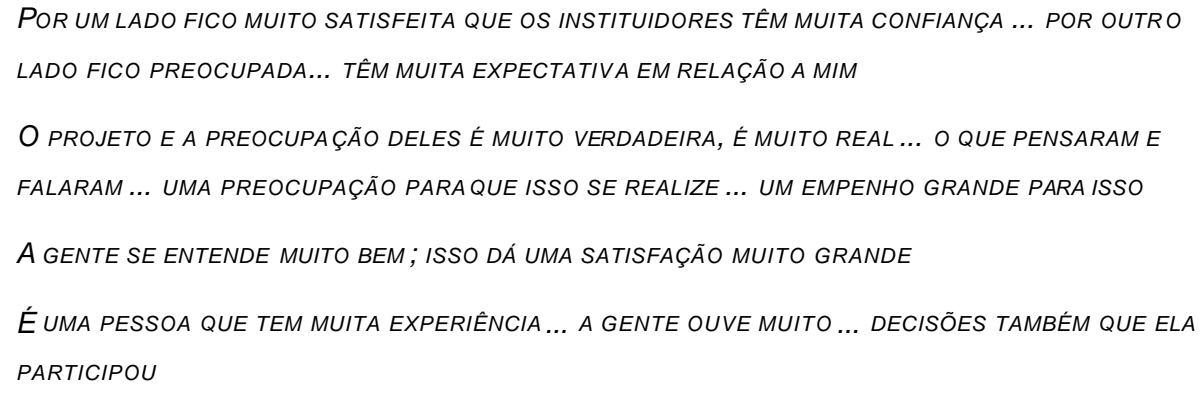

Os comentários acima revelam que o desenho da organização foi feito com a participação dos dois entrevistados, nos últimos 3 anos, embora com papéis diferentes. O conselheiro tem sido o responsável pela iniciativa, enquanto a executiva tem aparentemente exercido um papel mais técnico. 
Ambos concordam que é uma organização ainda jovem, amadurecendo, no começo de sua vida, com uma certa instabilidade institucional e financeira. Sentem-se motivados pela sua proposta e pelo que ela pode vir a realizar. Há uma valorização da qualidade e um processo de "acomodação" interna, com pessoas chave ainda procurando definir com clareza o melhor papel a ser exercido.

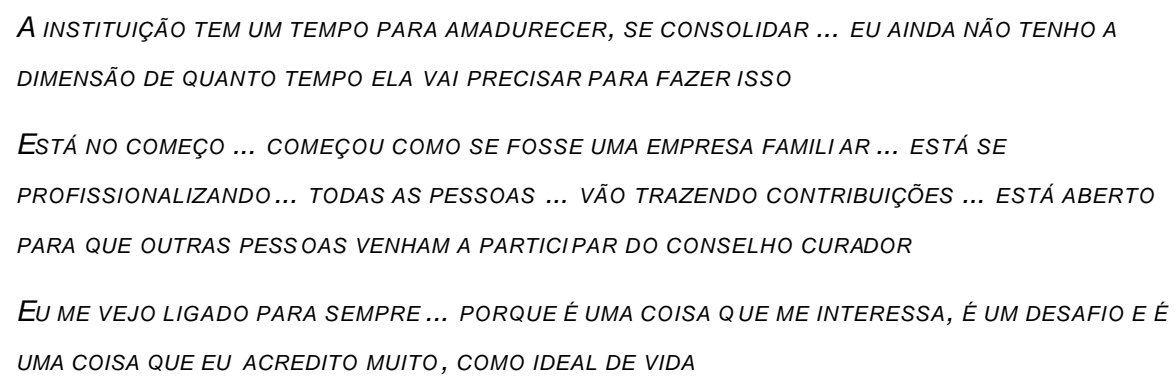

\subsubsection{O Papel do Conselho no nos Incheidentes Crítíticos}

As entrevistas versaram sobre 4 incidentes:

- Implantação do projeto de atendimento. A entidade conseguiu levantar todos os recursos que necessitava para iniciar suas operações, exceto o capital de giro - o que conselho teve então que tomar a decisão de usar ou não o fundo institucional para isso.

TODO ESSE TEMPO DE ELABORAÇÃO DO PROJETO, A CONCESSÃO DO PRÉDIO, O FINANCIAMENTO DO BNDES ... CHEGOU TUDO PRONTO E NÃO TINHA FINANCIAMENTO, DINHEIRO PARA COBRIR

OS INSTITUIDORES DEFINIRAM QUE ESTARIAM USANDO O DINHEIRO DO FUNDO INSTITUCIONAL ... CADA UM DELES COLOCOU UM TANTO ... IRIAM COMEÇAR COM ESSE DINHEIRO DO FUNDO INSTITUCIONAL E AÍ CONTINUAR COM A CAPTAÇÃO DE RECURSOS ... ATÉ HOJE ELE AINDA NÃO ESTÁ TODO COBERTO NAS DISCUSSÕES APAREC IA UMA CONFIANÇA GRANDE DE QUE IA SER FÁCIL CAPTAR RECURSOS, PELA IMAGEM DOS INSTITUIDORES... DE QUE TODO MUNDO IA QUERER AJUDAR ... AI CHEGOU O MOMENTO DE DECIDIR: VAMOS OU NÃO VAMOS? O PTOU SE POR CORRER ESSE RISCO: TIRAR ESSE DINHEIRO DO FUNDO INSTITUCIONAL, QUE A PRINCÍPIO NÃO ERA PARA SER MEXIDO ... EM NENHUM MOMENTO SE TINHA PENSADO EM POR NA OPERAÇÃO

ERA UMA QUESTÃO COMPLICADA ... PARA VENDER O PROJETO SERIA MELHOR ELE ESTAR EM ANDAMENTO ... OU A GENTE CONSEGUIRIA PARCEIRO COM ELE NO PAPEL SÓ? ... REPRESENTAVA $40 \%$ DO TOTAL DO FUNDO

(PROCESSO dE DISCUSSÃO) DEMOROU CERCA DE UNSSEIS MESES... A GENTE ESTAVA DISCUTINDO SE ERA PRUDENTE, SE NÃO IA COLOCAR EM RISCO TODA A IDÉIA ... ENQUANTO SE DISCUTIA, BUSCAVA-SE PARCEIROS ... FORAM VÁRIAS DISCUSSÕES ... QUANDO A GENTE FEZ ORÇAMENTO, TINHA PEDIDO PARA FAZER ORÇAMENTO DA REFORMA ... QUANDO CHEGOU O PREÇO, ASSUSTOU MAIS AINDA COMEÇAR AS REFORMAS SERIA UM COMPROMISSO COM A COMUNIDADE ... AFETARIA ATÉ A CREDIBILIDADE, NOSSA GRANDE FORÇA

- Convênio com a prefeitura. A entidade foi procurada pela prefeitura para realizar um convênio e implantar uma creche - o conselho teve que decidir se aceitaria ou não, uma vez que fazer o convênio naquele momento significava abrir a creche com um padrão de qualidade abaixo do planejado. 
a Secretaria de Ação Social da Prefeitura nos procurou para conhecer o espaço ... QUERIAM FAZER UM CONVÊNIO, UMA PARCERIA ... QUERIAM FAZER UM PED IDO ESPECIAL PARA IMPLANTAR CRECHE

ESSE CONVÊNIO DARIA PARA A GENTE PAGAR SALÁRIOS MUITO BAIXOS PARA OS PROFESSORES ... A GENTE TEM AQUELE PADRÃO DE PROFISSIONAL, DE QUALIDADE ... DÁ UM CUSTO MUITO MAIOR DO QUE O CONVÊNIO DA PREFEITURA OFERECE

NUM PRIMEIRO MOMENTO A GENTE SE ENTUSIASM A MUITO... A PROPOSTA DA SECRETARIA FOI UM RECONHECIMENTO DO NOSSO TRABALHO ... E A GENTE ACHA IMPORTANTE ESSA PARCERIA COM O PODER PÚBLICO ... É UMA OPORTUNIDADE

A [DIRETORA EXECUTIVA] ACHAVA QUE DAVA ... TINHA PLANO DE ENVOL VER OS CLUBES ... CADA CLUBE ESTAR ASSUMINDO UMA SALA, ETC. ... A GENTE AÍ RECUPEROU TODO ESSE MOMENTO DO CASO ANTERIOR ... LEMBRAVA: OLHA, A GENTE JÁ ESTÁ COM UM FURO ... NESSE PERÍODO TODO A FACILIDADE NÃO ERA TANTA DE CONSEGUIR RECURSOS

CHEGOU UM DIA QUE A SAS PRESSIONOU POR RESPOSTA ... TINHA QUE DAR RESPOSTA ATÉ AMANHÃ ... EU LIGUEI PARA O [INSTITUIDOR] ... ELE FALOU NÃO ... E DEU TODAS AS JUSTIFICATIVAS: NÃO DÁ PARA ASSUMIR ESSE COMPROMISSO... NÃO TEMOS OS RECURSOS ... NÃO VAMOS COMEÇAR COM UMA QUALIDADE DIFERENTE ... PARECIA QUE ELE JÁ TINHA TODA UMA REFLEXÃO ... NÃO DAVA PARA REUNIR O CONSELHO, NÃO ACHEI A [DIRETORA EXECUTIV A]

- Decisão de se apoiar em uma instituição já estabelecida. Os instituidores resolveram buscar apoio para desenvolver a idéia que tinham para sua organização.

ELE TINHA A IDÉIA DEUM PROJETO, EU OUTRO... ACHEI QUE A GENTE PODERIA ESTAR FORTALEC IDOS SE A GENTE JUNTASSE... ERAM MUITO PARECIDOS ... ELE TOPOU... DEIXOU DE SER UMA AÇ ÃO DE UM ATLETA... DOIS ATLETAS DE DESTAQUE ... JÁ MUDOU O FOCO

O PRIMEIRO PASSO FOI A GENTE SE APOIAR NUMA INSTITUIÇÃO JÁ BEM ESTABELECIDA, RECONHECENDO NOSSOS LIMITES NA ÁREA ... RECONHECER QUE ESTÁVAMOS ENTRANDO NUM MEO QUE NÃO ERA O NOSSO

EU TINHA UM CONTATO COM A [ENTIDADE APOIADORA] ... COM A SUPERINTENDENTE ... ELA DISSE QUE O DIA QUE EU QUISESSE EU PODERIA ENTRAR EM C ONTATO COM ELA ... LEVEI AO [OUTRO INSTITUIDOR] ... FOI UMA DECISÃO CONJUNTA

NA PRIMEIRA CONVERSA ... A GENTE DISCUTIU A IDÉIA, O PROJETO ... NA SEGUNDA REUNIÃo ... ELE PERGUNTOU QUAIS ERAM MINHAS INTENÇÕES POLITICAS ... ME ASSUSTEI COM AQUILO ... AO MESMO TEMPO ME ASSUSTOU E ME DEU CONFIANÇA ...

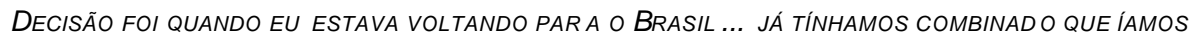
FAZER ALGUMA COISA NOBRASIL ... [OUTRO INSTITUIDOR] CONCORDANDO EM COMEÇ AR, MESMO DISTANTE

- Concessão de espaço pelo poder público. Conselheiros tiveram que reavaliar sua opinião a respeito de parcerias com o poder público e mobilizar seus contatos para viabilizá-las.

EU PARTICULARMENTE NÃO ACREDITEI ... SEMPRE TIVE RECEIO ... QUIS FAZER COMPLETAM ENTE INDEPENDENTE DO PODER PÚBLICO, QUE EU VIA UM POUCO COMO ADVERSÁRIO AMADURECEMOS ESSA IDÉIA DE PROCURAR UMA PARCERIA COM O PODER PÚBLICO PARA CONSEGUIR UM ESPAÇO ... ISSO FOI DISCUTIDO ... 
HOUVE UM JANTAR COM UM REPRESENTANTE DE [UMA EMPRESA], A[DIRETORA EXECUTIVA] E UM REPRESENTANTE DO ESTADO, QUE ERA MUITO LIGADO À PRIMEIRA DAMA... AÍ SURGIU A PRIMEIRA POSSIBILIDADE DE CONTAR COM UMA PARCERIA...

DEPOIS DISSO A GENTE FOI DISCUTIR ... NÃO FOI NUMA REUNIÃO ... EU NA FRANÇA, [OUTRO INSTITUIDOR] NA ITÁLIA, [DIRETORA EXECUTIVA] NO BRASIL... ACHAMOS QUE NÃO TERIAM GRANDES PROBLEMAS ... A [ENTIDADE APOIADORA] TAMBÉM ESTAVA PARTICIPANDO COMO ASSESSORA ... A OPINIÃO DELES TAMBÉM PESOU

Pelos comentários, é um conselho de uma organização jovem, que exerce seu papel de maneira informal, pouco sistemática e muito influenciada pela confiança no principal instituidor, uma liderança carismática. É um conselho que orienta -se por uma visão institucional - intuitiva que seja - e que preocupa-se em discutir entre si os problemas que surgem, apesar dos membros estarem distantes entre si. Esta situação, entretanto, deixa um pouco confusa a coordenadora:

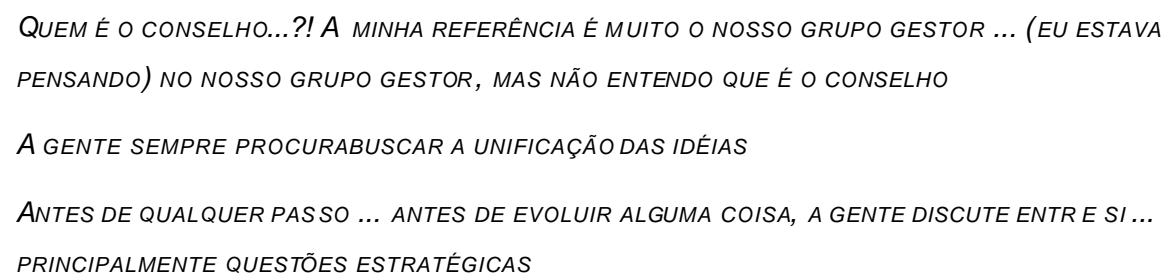

O caráter do conselho é dado principalmente pela figura do instituidor, que aglutina as pessoas ao redor de si e lidera os trabalhos e a atuação dos demais conselheiros. É um grupo pequeno, com vínculos pessoais, que fala-se muito diretamente, mas reúne-se pouco, caracterizando um estilo de trabalho mais improvisado.

Para que este conselho tenha uma ação efetiva, tem sido importante:

- A vinculação com a "causa" institucional, a identidade do grupo em torno de uma idéia;

- Um sentimento de confiança no potencial do grupo;

- A intuição do instituidor;

- O aproveitamento das capacidades individuais de cada membro, inclusive da credibilidade e da rede de relações.

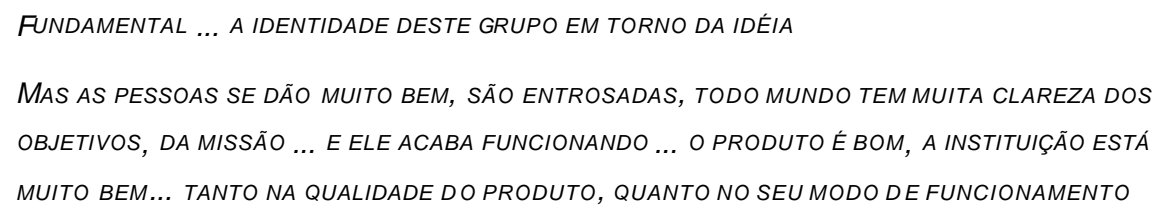

A importância deste conselho na entidade está ainda muito vinculada à importância do instituidor - o conselho tem mais um peso simbólico, gerando um mínimo de tranqüilidade e segurança à pessoas, porém estando ainda num estágio embrionário e pequeno. $\mathrm{O}$ instituidor no cotidiano institucional traz a seguinte contribuição, segundo a coordenadora:

AVALIZAR E DAR UMA CENTRADA NAS AÇÕES... QUANDO ESTAMOS MAIS PERDIDOS, MAISINSEGUROS, ELE TRAZ UMA OUTRA VISÃO 


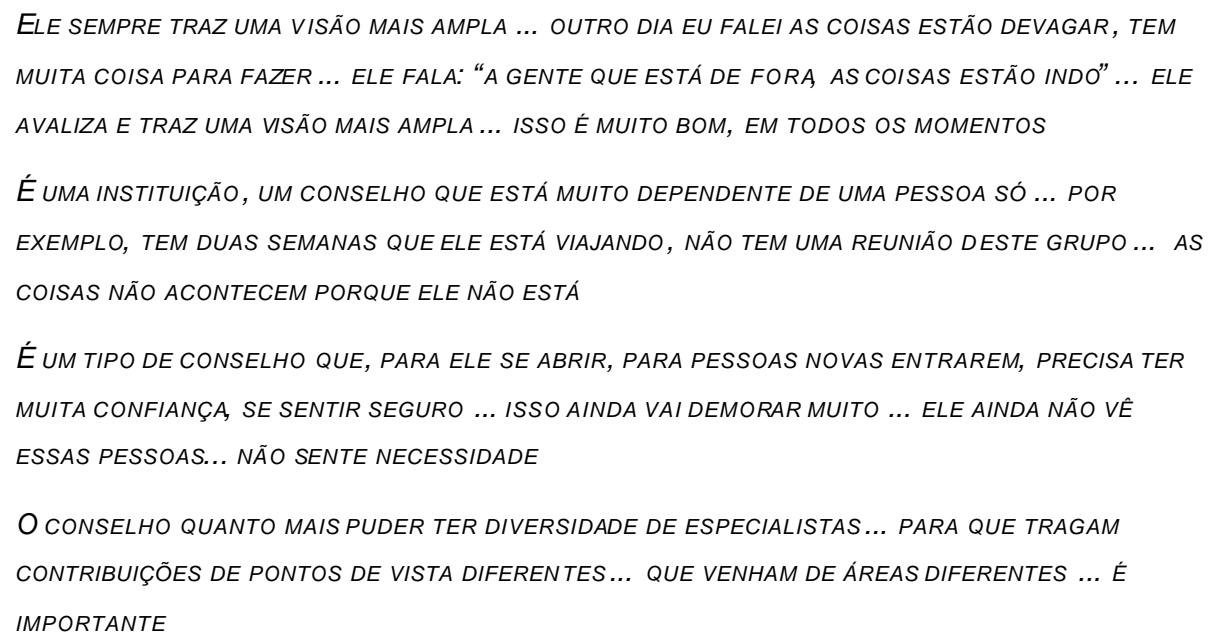

Com base nos comentários acima mostram que o conselho tem sido efetivo por:
a) Assumir riscos;
b) Aproveitar suas próprias experiências para aprender;
c) Analisar os problemas e questões com cuidado;
d) Agir como instituidor da organização;
e) Propor novas iniciativas;
f) Participar ativamente da articulação política.

\subsubsection{Competências desenvolvidas}

Competência analítica: o conselho curador, por menor que seja, é um grupo que procura amadurecer as decisões e consultar lideranças e técnicos da área. Os processos de decisão são lentos, esperando até o "último momento" para amadurecer as decisões, sem deixar de agir positivamente enquanto não se chega a uma solução. É um conselho capaz de ponderar os pontos fortes da organização e de lidar com diferenças de opinião, explorando assessores externos e internos para discutir alternativas.

Competência contextual: é um grupo que carrega em si e age simbolicamente para reforçar os principais valores da organização, especialmente por ser um grupo fundador. Evidentemente, faz isso informalmente.

Competência educacional: é um grupo que esforça-se por aprender com as suas próprias decisões e experiências e que busca conhecimentos de outros; porém, aparentemente realiza pouco em termos de auto-avaliação e formação.

\footnotetext{
UM ERRO FOI TER COMEÇADO GRANDE ... NOSSA IDÉIA É GRANDE, AS POSSIBILIDADES SÃO ENORMES, TEM POTENCIAL GRANDE... TER COMEÇADO GRANDE PODE NOS ATRASAR UM POUQUINHO 
Competência estratégica: liderado pelo principal instituidor, é o grupo responsável pelo desenho institucional e pelo projeto de atendimento. Na tomada de decisões, consegue discernir o que é prioridade, evitando que a simples demanda de recursos interfira na identidade organizacional. Ainda, tem coragem de assumir riscos, assumindo internamente que tiraria "do bolso" os recursos, caso fosse necessário. Um grande valor, do ponto de vista estratégico, está no fato de que o conselho trouxe uma idéia de iniciativa e a foi amadurecendo, com ajuda de outros

Competência interpessoal: há um trabalho do conselho como grupo, embora com grande caráter pessoal e de informalidade. Há, entretanto, também ações individuais. Por ter um caráter familiar e de alto grau de amizade, predominam relações de cordialidade, permitindo a convivência de opiniões diferentes - o grupo sabe discuti-las e conciliá-las.

Competência política: É um conselho preocupado politicamente, que tem, nutre e disponibiliza sua rede de relações e procura estar atento às demandas e expectativas da comunidade. Em pelo menos um dos casos o conselho deu importância à expectativa da comunidade, decidindo-se a realizar os compromissos assumidos mesmo com algum grau de risco. No caso da prefeitura, as relações foram preservadas, embora aparentemente tenha se gerado um afastamento. Porém, nenhum conselheiro participou diretamente das conversas com os representantes da prefeitura, nem tampouco procurou verificar se compreendia 0 contexto e os interesses daquela parte realmente. Preocupou-se, isso sim, em apresentar um conjunto de justificativas para sua decisão em não aceitar o convênio.

\subsubsection{ENTIDADE 6}

\subsubsection{Contexto instititụcional}

Segundo o estatuto, a Entidade 6 "tem por finalidade o amparo às crianças e ou adolescentes principalmente de rua, abandonados ou que tenham ligações de família frágeis", desenvolvendo "uma ação educativa". Sua missão é "contribuir para a formação social e cultural de adolescentes e crianças carentes", atuando através de projetos de educação pelo trabalho, pelo uso da arte, comunicação e tecnologia e de reciclagem de conhecimentos. Na forma jurídica de associação, foi fundada em 1993e oferece:

UM PROJETO DE FORMAÇÃO ... PREPARAR PARA O MUNDO DO TRABALHO ... MAIS OFICINAS LUDO-

PEDAGÓGICAS

O conselheiro entrevistado tem 72 anos e está há 4 participando das atividades da Associação. É um empresário industrial com formação em engenharia têxtil e nascido na França.

GOSTEI DO [ENTIDADE 6] PORQUE GOSTEI DO OBJETIVO, GOSTEI DO PÚBLICO, ESSAS CRIANÇAS QUE SÃO REALMENTE SUPER-CARENTES, ACHEI QUE PODIA FAZR MUITA COISA...

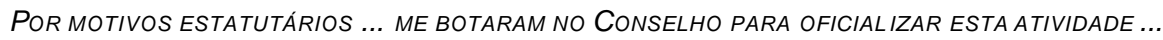
1998

PreCISEI CONHECER MEL hOR O [ENTIDADE 6] ... EU CONHECIA SUPERFICIALMENTE ... EU NÃO TINHA NOÇÃO MUITO EXATA DO QUE ERA A CONSTITUIÇÃO DO[ENTIDADE 6], A SUA ORIGEM, OS SEUS ESTATUTOS... 
QUANDO VOCÊ AVANÇA NA IDADE, VOCÊ PERCEBE CADA VEZ MAIS QUE NÃO PODE SE ALIENAR NOS PROBLEMAS DA COMUNIDADE

SE VOCÊ ESTÁ BEM NUM PAÍS QUE ESTÁ MAL, SE VOCÊ ESTÁ BEM NUM MEIO QUE ESTÁ MAL, NÃO É VIÁVEL ... VOCÊ CHEGA À CONCLUSÃO DE QUE VOCÊ NÃO PODE DEIXAR DE PARTIAPAR DE UMA FORMA OU DE OUTRA ... NÃO DANDO ESMOLA NOS FARÓIS, PORQUE NÃO RESOLVE NADA

EU VIVO NUM BAIRRO DE GENTE BEM DE VIDA ... TEM 25 MIL MORADORES ... NO [ENTIDADE 6] TEMOS UMAS 100 PESSOAS QUE CONTRIBUEM MODESTAMENTE ... HÁ UMA TAL DISPARIDADE ENTRE A NECESSIDADE DO[BAIRRO] E A POSSIBILIDADE DE UM BAIRRO COMO [ARREDORES] QUE ME PERGUNTO: COMO É QUE POSSO AGIR PARA ENVOLVER ESSE PESSOAL ? ESSA É UMA FRUSTRAÇÃO... TEM MUITO POUCOS QUETEM UMA ATITUDE POSITIVA...

A liderança executiva é uma mulher e exerce profissionalmente a função de coor denadora pedagógica e administrativa da Associação, estando desde o final de 1998 na entidade:

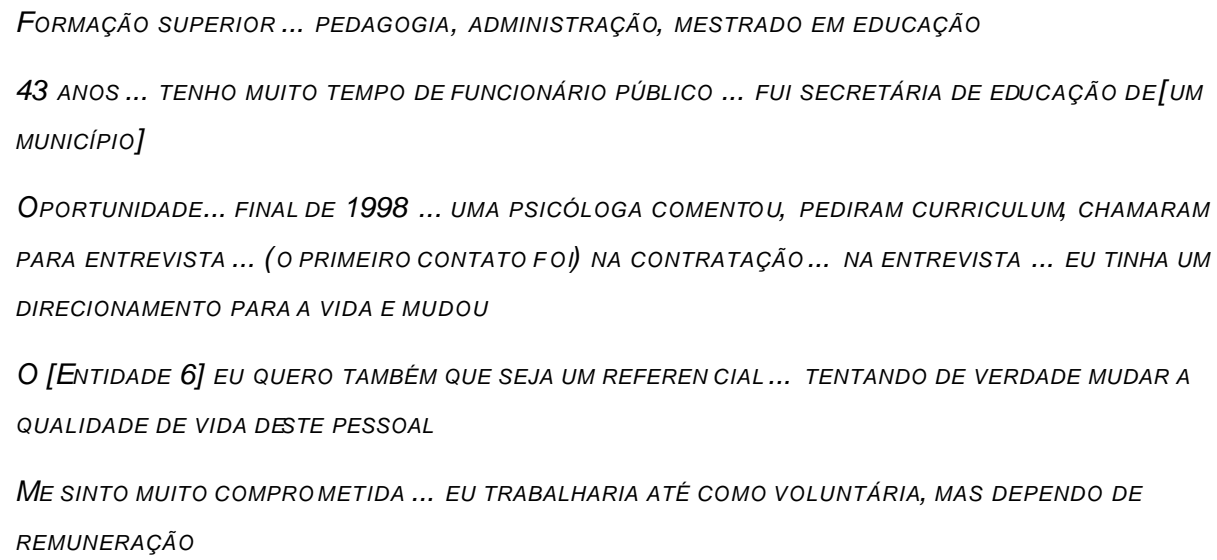

Ambos os entrevistados foram "recrutados" para a organização: a executiva via processo seletivo formal e o conselheiro por um processo informal - ele trabalhou como voluntário durante 2 anos, antes de se tornar membro do conselho.

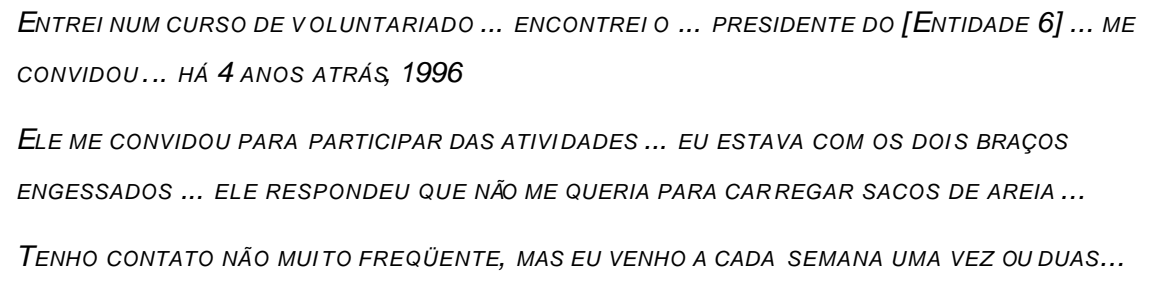

Os perfis do conselheiro e da executiva são bastante diferentes. Enquanto o conselheiro se aproximou à instituição por ideal, a executiva o fez mais por necessidade. Enquanto um passou a maior parte de sua vida trabalhando em empresas, a outra vi nculou-se basicamente a órgãos públicos. Enquanto um é francês, a outra é brasileira. Enquanto um é voluntário e mora num bairro de classe alta, a outra é remunerada e viúva, lutando para manter e educar sua família. Ambos, entretanto, mostram grande entusiasmo pelo projeto de entidade em que estão trabalhando e afirmam que o que fazem ajuda-os a realizar seus ideais.

Vale destacar que nenhum dos dois tinha, anteriormente, um vínculo com as pessoas consideradas fundadoras da instituição. O processo de recrutamento não parece ter sido ao acaso em nenhum dos casos: 
o conselheiro foi encontrado num curso sobre voluntariado e a executiva num processo seletivo aberto. $O$ bom nível de ambos é resultado de um processo de recrutamento intencional.

$\mathrm{Na}$ [Entidade 6] existem uma diretoria e um conselho de administração, além de uma assembléia geral e um conselho fiscal. Segundo o estatuto, compete àdiretoria:

I. Elaborar o programa anual de atividades e executá-lo;

II. Elaborar e apresentar, ao conselho de administração e àassembléia geral, o relatório anual;

III. Entrosar-se com instituições públicas e privadas para mútua colaboração em atividades de interesse comum;

IV. Contratar e demitir funcionários.

A diretoria compõe-se de 6 pessoas, que devem se reunir uma vez por mês, com mandato de 2 anos.

O estatuto prevê que o conselho de administração seja composto por 7 a 15 membros, com mandatos de 2 anos, competindo-Ihe:

I. Elaborar, juntamente com a diretoria, o programa anual de atividades;

II. Convocar assembléias;

III. Manifestar-se sobre os relatórios e contas apresentadas;

IV. Acompanhar a gestão dos diretores;

V. Autorizar a locação de imóveis.

O conselheiros nomeado para exercer cargo na diretoria fica automaticamente afastado do conselho.

É possível identificar a presença de fundadores na Entidade 6: o ex-presidente da diretoria foi um dos fundadores e trabalha ativamente ainda hoje na instituição, como consultor. É jovem, tendo nascido nos anos 60 .

\subsubsection{O Papel do Conselho nos Incidentes Críticos}

Foram 4 os casos relatados pelos entrevistados, que se referiam a:

- Mudança da atitude frente aos cursos ministrados. O conselho discutiu a proposta de mudança de abordagem vinda da coordenação e convenceu uma parte do grupo de fundadores a adotá -la.

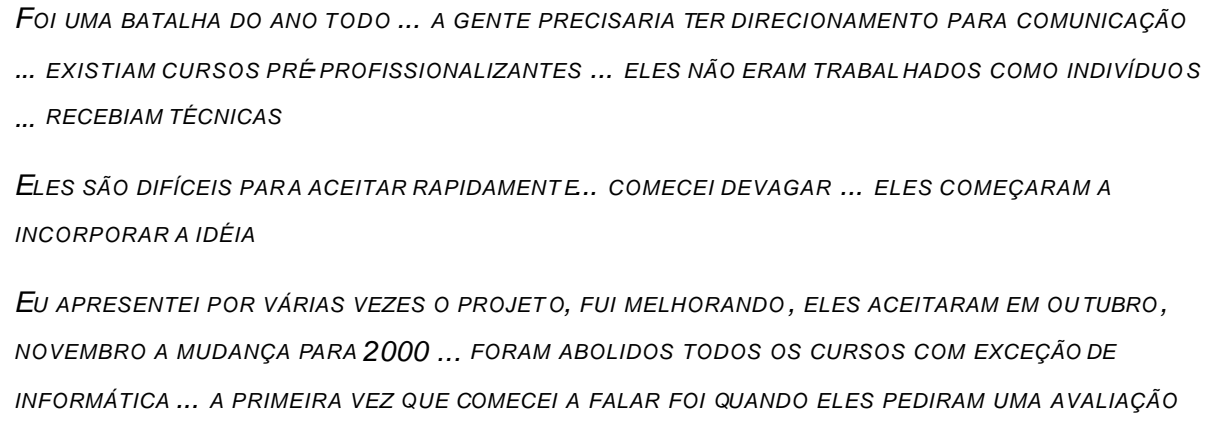


DOS CURSOS ... EU ACHAVA QUE NÃO ESTAVA OCORRENDO APRENDIZADO ... ELES PERGUNTARAM E EU FUI DANDO OPINIÕES ... ALGUNS CONSELHEIROS NÃO ESTAVAM MUITO SA TISFEITOS

EM JULHO, AGOSTO FOI A PRIMEIRA VEZ ... AÍ SURGE UMA SÉRIE DE DÚVIDAS ... APRESENTEI OUTRAS VEZES ... INVENTARAM UMA PESQUISA PARA VER SE REALMENTE O CURSO NÃO ESTAVA CORRESPONDENDO ... E FOI CONSTATADO

O CONSELHO TEVE ATUAÇÃO FORTE, PORQUE ALGUNS CONSELHEIROS TÊM ESSA MENTALIDADE MODERNA ... PELO FUNDADOR E ESPOSA NÃO TERÍAMOS MUDADO ... NÃO CONSEGUIRÍAMOS MAIS RECURSOS

EU FUI ENCARREGADO DE REVER E ANALISAR A IDÉIA DOS CURSOS; COM O PESSOAL, É EVIDENTE Nós NOS REUNIMOS ... [FUNDADOR JOVEM], [COORDENADORA] E EU PARA TENTAR TRAÇAR UMA LINHA ... DAÍ PARTIMOS PARA UMA SELEÇÃO DO PESSOAL, QUE NÓS FIZEMOS OS TRÊS JUNTOS TAMBÉM ... SEMPRE PARTINDO DO PRINCÍPIO DE QUE 3 CABEÇAS SÃO MELHOR DO QUE DUAS OU DO QUE UMA ... FOI UM CONSENSO DOS TRÊS A ESCOLHA DESSA TURMA

- Parceria com um grande hospital de São Paulo. O conselho descobriu a oportunidade da entidade apoiar um empreendimento que poderia trazer muitos benefícios àcomunidade e resolveu mobilizar-se para aproveitá-la.

Por amizade de alguém do conselho com alguém que era presidente do Rotary ... FoI MENCIONADA A IDÉIA DO [G RANDE HosPITAL] ABRIR UM POSTO DE SAÚdE; ... SE NÃO HOUVESSE DENTRO DO CONSELHO GENTE COM RELAÇÕES SOCIAIS OU PROJEÇÃO SOCIAL ... NÃO TERIA SURGIDO ESSA OPORTUNIDADE ...

VAI REDUNDAR PARA A ZONA QUE O[ENTIDADE 6] ATUA UMA COISA MARAVILHOSA ... ELES VÃO TER À DISPOSIÇÃO, SEM NECESSIDADE DE GASTAR DINHEIRO ... OS MELHORES MÉDICOS POSSÍVEIS...

A PRIMEIRA VEZ QUE OUVI FOI NUMA REUNIÃO DO CONSELHO, O ANTIGO PRESIDENTE MENCIONOU TER ENCONTRADO O PRESIDENTE DO ROTARY, QUE É UM AMIGO DELE, E QUE ESSE SENHOR MENCIONOU ESSA VONTADE DO [GRANDE HOSPITAL] ABRIR ... NUM LUGAR DESFAVORECIDO QUE ELE NÃO TINHA AINDA ESCOLHIDO...

Aí O CONSELHO UNANIMEMENTE APROVOU ESSA IDÉIA ... FOI DECIDIDO QUE A GENTE DARIA PARTE DA ÁREA DISPONÍVEL PARA CONSTRUIR UM CONSULTÓRIO...

Aío[Grande Hospital] VeIo aqui, VISITOU o [ENTIDADE 6], teVE uma IDÉIA do que É a zona onde A GENTE OPERA E CONFIRMOU A SUA INTENÇÃO ...

- Resolução de não mais desenvolver uma atividade que deu origem à instituição. O conselho discutiu o caso de um aluno que chegou àjustiça e convenceu a diretoria a abandonar um serviço prestado desde a fundação da entidade.

O [ENTIDADE 6] INICIALMENTE, ALÉM DOS CURSOS SEMFPROFISSIONALIZANTES QUE ELE TINHA, ELE ABRIGAVA AQUI 7 OU 8 ADOLESCENTES MANDADOS PELO CONSELHO TUTELAR, QUE ERAM CRIANÇASPROBLEMA ... TINHA UM CASAL QUE CUIDAVA DESSES JOVENS DENTRO DO [ENTIDADE 6] ...

TEVE PROBLEMAS SEXUAIS QUE REDUNDARAM EM PROBLEMAS LEGAIS ... CRIOU UMA SITUAÇÃO QUE COLOCAVA O [ENTIDADE 6] NUMA SITUAÇÃO PERIGOSA FRENTE ÀS AUTORID ADES DO MUNICÍPIO ... INTERVEIO O CONSELHO TUTELAR, JUSTIÇA, ETC. ... NÃO FOI FÁCIL SAIR DESTE NEGÓCIO... REDUNDAVA EM RESPONSABILIDADE DO [ENTIDADE 6] 
TEVE MUITA RESISTÊNCI A E MUITA DISCUSSÃO ... PORQUE TANTO DO PRÓPRIO [FUNDADOR], ... QUANTO DA DIRETORIA, QUE DURANTE ANOS AJUDOU ESSE NEGÓCIO ... ELES NÃO ACHAVAM BOM ABANDONAR ESSE NEGÓCIO

ESSE RUMO QUE ELE TOM OU AGORA DE SER CENTRO EDUCACIONAL ... NÓS NÃO TEMOS MAIS CASOS EXTREMOS ... CHEGOU-SE À CONCLUSÃO DE QUE O [ENTIDADE 6] NÃO PODERIA MAIS CORRER ESSE RISCO

NA PRIMEIRA REUNIÃO ... O PRÓPRIO [FUNDADOR] QUE TROUXE O PROBLEMA, PORQUE TINHA SIDO CONVOCADO PELO JUIZ ... A OPINIÃO DELE ERA QUE ERA SEM IMPORTÂNCIA, MAS EXISTIA UM PROCESSO ... O GRUPO REAGIU ACHANDO QUE ERA IMPORTANTE ... O FATO ERA QUE TINHA SIDO EXTRAPOLADO ... E NÍVEL DE JUSTIÇA QUE NÃO PODIA SER I GNORADO

O CONSELHO PONDEROU QUE SE CONTINUASSE O MESMO TIPO DE MORADIA, ESSES PROBLEMAS SE REPETIRIAM ... NÃO PODIA SER CENTRO EDUCACIONAL E MORAD IA ONDE ACONTECESSEM COISAS DESSE TIPO... O [ENTIDADE 6] ERA RESPONSÁVEL PELA CUSTÓDIA DESSAS CRIANÇAS ...

NA PRIMEIRA REUNIÃO ... EXPOSIÇÃO DOS FATOS ... O CONSELHO REAGIA ESTARRECIDO, MAS NÃO PUXOU CONCLUSÃO, SIMPLESMENTE FOI INFORMADO

NA SEGUNDA REUNIÃO ... APÓS PONDERAR ... O CONSELHO DIZ: VAMOS ABANDONAR A MORADIA

NA TERCEIRA REUNIÃO .... ACEITAÇÃO DA DIRETORIA

[FUNDADOR] REAGIU MAL ... PORQUE ERA IDÉIA DEL E ... A FORMAÇÃO DO [ENTIDADE 6] FOI NA BASE DOS MENINOS DE RUA... O RESTO DA TURMA REA GIU BEM, MESMO O PRESIDENTE ... O [FUNDADOR] DISSE QUE ELE IA CUIDAR, QUE ELE IA ACHAR SOLUÇÃO COM OS PADRES...

- Procedimentos financeiros internos. Houve um impasse entre a equipe técnica e o tesoureiro a respeito de um dissídio salarial, para o qual o conselho foi chamado a ajudar a solucionar.

O FINANCEIRO É TOTALMENTE FECHADO ... NINGUÉM SABE NADA ... O TESOUREIRO CONTROLA ... É UM CONTROLE TOTAL

Para comprar alguma coIsa tem QUe ESTAR PEDINDO AUTORIZAÇÃo ... EXISTE UM CAIXINHA ... PARA PEQUENAS DESPESAS

OCORREU ALTERAÇÃo dE 5\% No SALÁRIO dOS FUNCI ONÁRIOS ... ELE DEU, MAS RESOLVEU TIRAR DE ALGUNS... GEROU INSATISFAÇÃO NO GRUPO, NA EQUIPE

FIZEMOS PLANILHA COM [CONSELHEIRO] E [FUNDADOR] ... [FUNDADOR] RESPEITA ESSA PESSOA ... TRAÇAMOS NOMES E SALÁRIOS ... A PRIORI ESTAVA APRO VADO ... MAS ELE QUIS MUDAR... E NÃO PODIA ... TIVE QUE ACIONAR OS MEMBROS DO CONSELHO PARA RESOLVER ESTE IMPASSE ACONTECERAM REUNIÕES NAS CASAS DELES ENTRE TESOUREIRO, PRESIDENTE E MAIS ALGUNS CONSELHEIROS ... NÃO SE CHEGAVA A UM ACORDO ... DUAS, TRÊS REUNIÕES HOUVE DESGASTE ... OS FUNCIONÁRIOS PEGARAM PARA CONVERSAR A TESOUREIRA MARCARAM a Última REUNIÃo COM O CONSELHO, TESOUREIRA E PRESIDENTE ... HOUVE TROCAS DE "CARÍCIAS", EU NÃO ESTAVA ... VOLTOU-SE A DAR O DISSÍDIO ... ENFRENTARAM OTESOUREIRO ... EU OUVI FALAREM ALTO

$\mathrm{Na}$ Entidade 6, os conselheiros atuam tanto em conjunto, nas reuniões, quanto separadamente, em comissões ou comitês. Aparentemente, as decisões importantes são tomadas em grupo, depois de um processo de análise cuidadoso, dando espaço para cada um ser ouvido. Para o encaminhamento de 
assuntos mais específicos e operacionais é delegada autoridade aos conselheiros, em áreas prédeterminadas pelo conjunto - dessa forma busca-se permitir o envolvimento dos conselheiros com questões práticas. Nas reuniões abre -se espaço para os conselheiros fornecerem informações sobre os trabalhos das comissões, o que o mantém como um todo ligado ao que acontece concretamente na entidade. É também um conselho que comunica-se diretamente com a equipe técnica e com a diretoria e que acompanha regularmente as atividades. O processo decisório é baseado no consenso e na argumentação, sem predomínio do voto.

Pelos depoimentos, neste novo sistema de trabalho os conselheiros passam a trazer a realidade para as reuniões, a partir de questões que eles próprios têm que lidar. Ainda, os conselheiros se colocam disponíveis para auxiliar em processos específicos (como um processo de seleção ou a organização de uma planilha) em conjunto com a equipe técnica.

No caso dos procedimentos financeiros internos, o conselho atuou especificamente como "instância de apelação", tirando proveito tanto de sua autoridade, quanto de sua imparcialidade potencial.

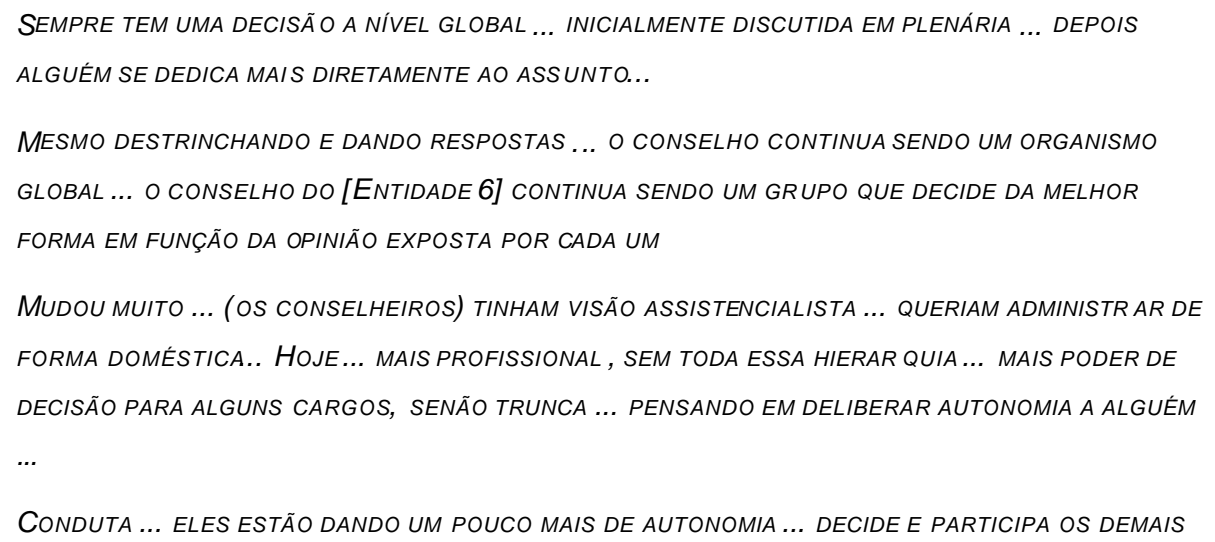

Com base nos depoimentos pode-se afirmar que o conselho tem sido importante para ajudar a organização em seu desenvolvimento, superando resistências. O conselho tem sido importante, também, no direcionamento da entidade e no equilíbrio das tensões internas entre as principais lideranças - a atuação do conselho como grupo favoreceu, por exemplo, a mudança da abordagem dos cursos e o abandono de um serviço tradicional prestado.

O CONSELHO É BOM ? É, ELE TE DÁ UM APOIO ... MAS UM ELEMENTO TRUNCA TUDO ...

O caso do hospital, entretanto, deixa claro que o conselho está preocupado com o benefício da comunidade:

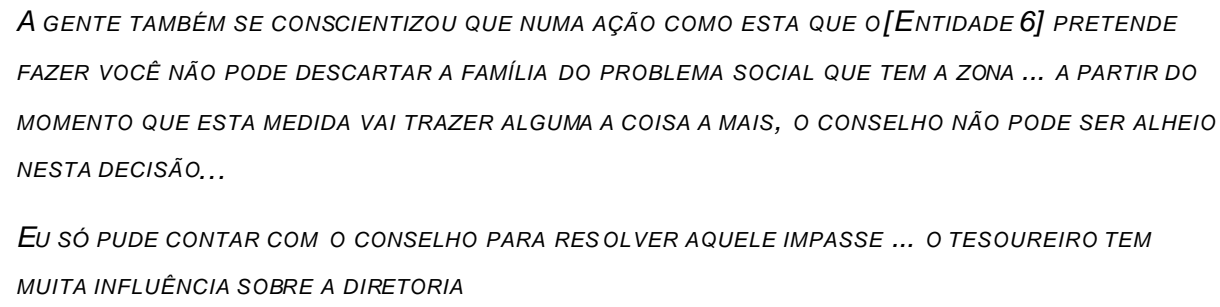


Pelos casos descritos, há uma diferenciação bem clara entre o conselho, a diretoria e a coordenação da entidade. O conselho vem assumindo, lentamente, uma liderança mais constitucional, a diretoria tem um papel organizador e estruturador e a coordenadora exerce uma liderança técnica. O papel organizador do presidente do conselho fica bem exemplificado no caso em que ele propôs aos conselheiros uma nova forma de organização e atuação dos conselheiros.

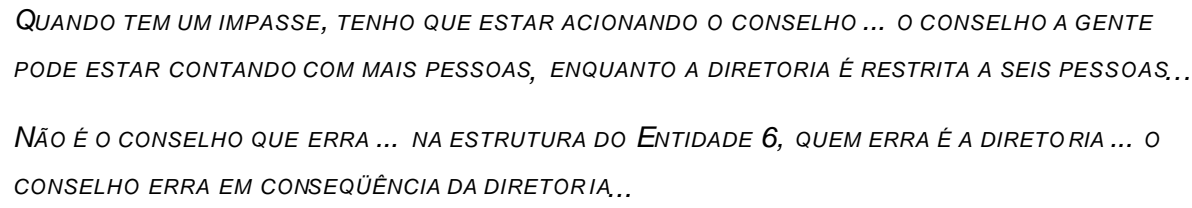

O papel do conselho, pelo que sugerem os depoimentos, é tanto de supervisor dos resultados das atividades e programas institucionais, quanto de alavancador do desenvolvimento e do impacto da entidade na sociedade. Nos incidentes descritos, parecia haver uma questão relativa ao desenvolvimento da organização por trás, que era a passagem de um estágio fundador ou pioneiro para um estágio mais profissionalizado. O envolvimento do conselho favoreceu, aparentemente, o prosseguimento deste processo.

O conselho pode ser responsabilizado (não isoladamente) pelos seguintes resultados:

- Conseguiu mudar sua própria forma de operar;

- Mudou o direcionamento da instituição na sua principal área de atuação;

- Ampliou o leque de parcerias da instituição;

- Teve impacto sobre a quantidade e qualidade do atendimento àpopulação;

- Superou, sem rompimentos, uma resistência dos fundadores;

- Contribuiu para a manutenção da satisfação da equipe técnica interna.

Dentre as suas principais características que contribuíram para isso, pode-se destacar:

- Havia um processo decisório previamente acordado, baseado no consenso;

- Os conselheiros mantiveram uma boa relação entre si;

- Houve uma preocupação em entender a instituição e seus projetos para poder deliberar;

- O conselho soube manter-se dentro do seu papel e delegar autoridade;

- Houve clareza quanto ao nível de autoridade e responsabilidade atribuído a cada conselheiro;

- Manteve -se voltado para o futuro, tanto para antecipar problemas potenciais, quanto para projetar aquilo que deve ser a instituição;

- Consultou outras instâncias da organização para as suas decisões.

\subsubsection{Competênchasas desenvoolvididas}

Competência analítica o conselho da Entidade 6 tem uma boa capacidade analítica, discutindo os problemas com cuidado, durante mais de uma reunião, ouvindo as pessoas no papel executivo, colocando 
perguntas, ouvindo opiniões antes de decidir e dedicando tempo à análise de propostas. É um dos poucos conselhos que se utilizou de pesquisas e levantamentos técnicos para orientação.

É um conselho que convive com diferenças de opinião, dispondo -se a "enfrentar" pessoas com opinião forte e com autoridade de fundador - deste ponto de vista, o processo analítico cuidadoso parece ser uma importante fonte de energia para superar resistências e ajudar a organização a avançar para um novo patamar de desenvolvimento. Diferenças de opinião existem e são tratadas "a portas fechadas" pelo conselho.

\section{UM CONSELHO TEM QUE TER DIVERSIDADE DE GENTE PARA PODER TRAZER ELEMENTOS DIFERENTES NA CONCEPÇÃO DO PROBLEMA...}

Entretanto, o processo analítico do conselho não é bem compreendido pela coordenadora, que manifestou incômodo pelo número de reuniões para avaliação do seu novo projeto pedagógico e pela solicitação da avaliação dos cursos.

Competência contextual: o conselheiro entrevistado mostrou um bom grau de competência contextual ao primeiro procurar conhecer em maior profundidade o trabalho da Entidade 6, para depois dar sugestões e palpites. O conselho mostra esta competência também ao dedicar bastante tempo ouvindo a equipe executiva e relatos de pessoas que estão acompanhando as operações da entidade. É um conselho, entretanto, que está liderando a transição de uma fase "fundadora" e "doméstica" para uma fase mais profissional - portanto questionando uma parte da cultura e das tradições da Entidade 6.

Os depoimentos sugerem que a assimilação da cultura institucional acontece, porém, mais em função do esforço e dedicação individuais e pelo contato com os fundadores, do que por iniciativas formais e sistemáticas.

Competência educacional: dentre as principais iniciativas que denotam essa competência estão um curso de voluntariado, a retroalimentação de um conselheiro para outro a respeito do seu desempenho e a discussão de idéias para melhorar seu próprio desempenho. Tudo isso é feito de maneira informal e parece estar trazendo benefícios.

HAVIA UMA PESSOA QUE MONOPOLIZAVA A PALAVRA E AS DECISÕES E ORIENTAÇÕES ERA ELE QUE DAVA ... UM DIA FALEI COM ELE... SE UMA REUNIÃO É PAR A TE OUVIR FALAR, NÃO PRECISA FAZER, VOCÊ DECIDE SOZINHO ... ELE MUDOU TOTALMENTE DE ATITUDE ... ELE NÃO TEM MAIS ISSO ... NÓS VAMOS FAZER

É um conselho que foi capaz de mudar sua maneira de atuar, conforme se percebe pelos depoimentos do conselheiro:

\footnotetext{
O PRESIDENTE DO CONSELHO ... FALOU QUE A CADA MEMBRO DO CONSELHO PODERIA SE ATRIBUIR UMA FUNÇÃO MAIS EXECUTIVA DO QUE DE CONSELHO, NA MEDIDA QUE O PESSOAL ACEITASSE , PARA FACILITAR TRABALHO DA DIRETORIA E PARA AMPLIAR A POSSIBILIDADE DA AÇÃO DO CONSELHO SOBRE O ANDAMENTO DA COISA Aí UM FOI ENCARREGADO DA CAPTAÇÃO, UM FOI ENCARREGADO DA RELAÇÃO COM AS AUTORIDADES ... EU FUI ENCARREGADO DE REVER E ANALISAR A IDÉIA DOS CURSOS; COM O PESSOAL, É EVIDENTE
} 
NESSA DECISÃO TOMADA NO CONSELHO FOI TAMBÉM CLAREADO QUE A RESPONSABILIDADE ATRIBUÍDA A CADA UM DAVA TAMBÉM A CADA UM A AUTORIDADE PARA RESOLVER OS PROBLEMAS, QUER DIZER, NÃO DEPENDIA MAIS DO CONSELHO COMO UM TODO, JÁ QUE FOI DELEGADA UMA FUNÇÃO A C ADA UM REUNIÃo do CONSELHO, tínHAMOS UMA POR MÊS, SISTEMATICAMENTE ... 10 A 12 PESSOAS SE REUNIAM MENSALMENTE ... A GENTE CONSTATOU QUE ESSA REUNIÃo FICAVA POUCO NO CONCRETO ... MEXIA MUITAS IDÉIAS, MAS NÃO CONCLUÍA MUI TA COISA, DEIXAVA PARA RESOLVER ASSUNTO JÁ DISCUTIDO AMPLAMENTE, UMA VEZ, DUAS VEZES, TRÊS VEZES ... ONDE TEM MUITA GENTE OPINANDO NÃO SAI NADA... DAÍ NASCEU A IDÉIA DE DEFINIR MELHOR A FUNÇÃO DE CADA UM, DE ATRIBUIR A CADA UM UMA FUNÇÃO E OS MEIOS PARA CUMPRIR A FUNÇÃO

REALMENTE FOI UMA BOA DECISÃO, PORQUE ATÉ AS REUNIÕES POSTERIORES A ESSA DECISÃO FORAM MUITO MAIS CONSTRUTIVAS... CADA UM TRAZIA EVENTUAIS PROBLEMAS SURGIDOS NA SUA ÁREA, MAS TRAZIAM O PROBLEMA E A SOLUÇÃO DADA, NÃO A PESQUISA DE UMA SOLUÇÃO QUE AÍ ADIAVA TUDO...

É possível aribuir uma parte desta competência educacional à coragem, humildade e franqueza das pessoas que fazem parte daquele grupo, bem como à existência de um relacionamento saudável com a diretoria. Ainda, denota-se um certo senso de auto-responsabilidade pelo próprio desempenho.

Competência estratégica: o conselho do Entidade 6 mantém-se voltado para o futuro, orientando suas discussões para um "projeto de entidade" que existe implicitamente (e não um plano institucional formal) e para os problemas existentes na zona em que está inserida a organização. Aparentemente é um conselho que utiliza a visão de liderança da diretoria, mas que procura conduzir a instituição, ao invés de simplesmente aprovar ou apoiar algo. Constitui-se em uma instância em que questões que afetam a organização toda, funcional ou simbolicamente, são discutidas e onde existe um olhar intencional para o futuro e para aquilo que se quer ser. Devido a essas características aparentemente tem ajudado a organização a amadurecer, não sem atritos, de um estágio fundador, para um estágio mais profissionalizado. A tensão que existe entre diretoria e conselho é resultado deste processo, além do questionamento se realmente há necessidade de ter os dois órgãos tão bem diferenciados.

O conselho no caso do aluno que foi parar na justiça sem dúvida agiu buscando prevenir problemas futuros, embora tomasse uma decisão baseada em um único acontecimento. Vale destacar que mostrou que estava atento àfala da diretoria, que quase "passou por cima" do assunto.

Uma competência estratégica para a qual este grupo chama a atenção é a capacidade de trazer a realidade às reuniões. As reuniões, especialmente com a mudança no funcionamento interno do conselho, parecem ter melhorado pelo simples fato de estarem conseguindo tratar de problemas reais, trazidos pelos próprios conselheiros.

Competência interpessoal: o conselho desta organização apresenta uma boa coesão como grupo, conseguindo conviver com tensões, embora não hajam grandes indicativos do relacionamento entre os conselheiros, nem de que o grupo defina para si algumas metas. Nota-se, entretanto, um clima propício para que cada um sinta-se livre para expor as suas idéias e opiniões.

O processo de recrutamento de novos membros parece ser pelo menos considerado pelo conselho e pela diretoria: tanto no caso da coordenadora como no do conselheiro houve uma preocupação em atrair pessoas com determinadas qualificações, denotando uma certa intencionalidade no processo e no estabelecimento de critérios. Sobre o processo sucessório, ao contrário do de recrutamento, poucos 
indicativos foram obtidos. Há indícios de que é informal e que está havendo uma transição entre um estágio em que a liderança foi dos fundadores, para um estágio em que a liderança está com as pessoas mais tecnicamente preparadas e maduras.

Competência política: considerando o caso dos procedimentos financeiros, é um conselho que aparentemente ocupa-se com as relações entre os diferentes constituintes organizacionais e respeita os papéis de cada instância e grupo to processo decisório. No caso com a justiça, entretanto, o conselho preocupou-se bastante com a relação com as autoridades, mas aparentemente pouco fez para assegurar um bom seguimento aos adolescentes. Ainda, parece que a questão ficou mal resolvida entre o fundador e o conselho, pois o primeiro teve que "engolir" a decisão e ainda "se virar" com os meninos. Neste caso, de acordo com os depoimentos, o conselho não se preocupou em ouvir os envolvidos ou seus colegas.

Os relacionamentos e contatos de cada conselheiro parecem ser colocados à disposição da instituição, auxiliando a criar uma pequena comunidade de apoio a ela.

\subsubsection{SíNTESE DA ANÁLISE DOS DEPOIMENTOS}

O quadro a seguir busca sintetizar as características encontradas nos depoimentos analisados, entidad e por entidade: 


\begin{tabular}{|c|c|c|c|c|c|c|c|c|}
\hline Entidade & $\begin{array}{l}\text { Tipos de questões em que } \\
\text { há envolvimento direto do } \\
\text { conselho }\end{array}$ & $\begin{array}{c}\text { Papel } \\
\text { predominante } \\
\text { do conselho/ } \\
\text { diretoria }\end{array}$ & $\begin{array}{l}\text { Principais práticas de } \\
\text { denotam } \\
\text { competências }\end{array}$ & $\begin{array}{l}\text { Influência de } \\
\text { fundadores }\end{array}$ & $\begin{array}{l}\text { Estilo de trabalho } \\
\text { predominante }\end{array}$ & $\begin{array}{l}\text { Diferenciação } \\
\text { entre conselho e } \\
\text { diretoria }\end{array}$ & $\begin{array}{c}\text { Resultados } \\
\text { atribuíveis ao } \\
\text { conselho/diretor } \\
\text { ia }\end{array}$ & Destaques \\
\hline 4 & $\begin{array}{ll}\text { - } & \begin{array}{l}\text { Aceitação de uma } \\
\text { criança com perfil } \\
\text { diferente do usual }\end{array} \\
\text { - } & \begin{array}{l}\text { Busca do pai de uma } \\
\text { criança }\end{array} \\
\text { - } \quad \begin{array}{l}\text { Incêndio numa obra } \\
\text { institucional }\end{array} \\
\text { - } \quad \begin{array}{l}\text { Menina que se machuca } \\
\text { e não tem suporte }\end{array} \\
\text { - } \quad \begin{array}{l}\text { Intimação para } \\
\text { pagamento de multa ao }\end{array} \\
\text { IR } \\
\text { - Aprovação de estatuto } \\
\text { junto ao CNAS }\end{array}$ & $\begin{array}{l}\text { Decisório, } \\
\text { apoiador }\end{array}$ & $\begin{array}{l}\text { Tomada de decisões } \\
\text { baseadas em } \\
\text { argumentos, discussão } \\
\text { de opiniões diferentes, } \\
\text { estabelecimento de } \\
\text { metas para o grupo, } \\
\text { contato direto dos } \\
\text { conselheiros com o } \\
\text { público-alvo }\end{array}$ & $\begin{array}{l}\text { Alta -a } \\
\text { conselheira } \\
\text { entrevistada é a } \\
\text { principal } \\
\text { fundadora }\end{array}$ & $\begin{array}{l}\text { Envolvimento individual } \\
\text { direto em situações } \\
\text { emergenciais e com } \\
\text { caráter mais técnico ou } \\
\text { especializado, } \\
\text { mobilização de contatos } \\
\text { pessoais, discussão em } \\
\text { reuniões, relações de } \\
\text { amizade, presença } \\
\text { regular na entidade }\end{array}$ & $\begin{array}{l}\text { Inexistente - no } \\
\text { estatuto há } \\
\text { somente conselho } \\
\text { de administração e } \\
\text { conselho consultivo } \\
\text { (inoperante) }\end{array}$ & \begin{tabular}{|l|} 
Orientação do \\
contador, solução \\
de "casos \\
agudos", \\
preservação da \\
identidade \\
institucional, \\
garantia de \\
recursos com \\
isenção fiscal
\end{tabular} & $\begin{array}{l}\text { Existência de uma } \\
\text { gerência executi va, } \\
\text { remunerada, que } \\
\text { administra o dia-a- } \\
\text { dia }\end{array}$ \\
\hline 1 & $\begin{array}{ll}\text { - } & \text { Concurso para } \\
\text { construção de creche } \\
\text { modelo }\end{array}$ & $\begin{array}{l}\text { Decisório, } \\
\text { apoiador }\end{array}$ & $\begin{array}{l}\text { Discussão conjunta dos } \\
\text { problemas, solicitação } \\
\text { de opiniões a } \\
\text { lideranças externas, } \\
\text { decisão por } \\
\text { argumentos, análise de } \\
\text { erros do passado, } \\
\text { definição de } \\
\text { prioridades, encontros } \\
\text { freqüentes, } \\
\text { estabelecimento de } \\
\text { metas para o grupo, } \\
\text { consulta a algumas } \\
\text { audiências e parceiros } \\
\text { externos }\end{array}$ & \begin{tabular}{|l|} 
Alta -a \\
conselheira e a \\
principal liderança \\
executiva se \\
consideram \\
fundadoras da \\
organização
\end{tabular} & $\begin{array}{l}\text { Informal e operacional, } \\
\text { decisões coletivas }\end{array}$ & $\begin{array}{l}\text { Inexistente- no } \\
\text { estatuto há } \\
\text { somente conselho } \\
\text { de administração e } \\
\text { conselho consultivo } \\
\text { (inoperante) }\end{array}$ & $\begin{array}{l}\text { Manutenção da } \\
\text { qualidade do } \\
\text { trabalho em } \\
\text { momentos de } \\
\text { crise, criação de } \\
\text { um fundo de } \\
\text { reserva, } \\
\text { desenvolvimento } \\
\text { da entidade como } \\
\text { um todo }\end{array}$ & $\begin{array}{l}\text { A formação e } \\
\text { capacitação } \\
\text { permanente das } \\
\text { educadoras tem sido } \\
\text { a principal prioridade } \\
\text { da instituição }\end{array}$ \\
\hline
\end{tabular}




\begin{tabular}{|c|c|c|c|c|c|c|c|c|}
\hline Entidade & $\begin{array}{l}\text { Tipos de questões em que } \\
\text { há envolvimento direto do } \\
\text { conselho }\end{array}$ & $\begin{array}{c}\text { Papel } \\
\text { predominante } \\
\text { do conselho/ } \\
\text { diretoria }\end{array}$ & $\begin{array}{l}\text { Principais práticas de } \\
\text { denotam } \\
\text { competências }\end{array}$ & $\begin{array}{l}\text { Influência de } \\
\text { fundadores }\end{array}$ & $\begin{array}{l}\text { Estilo de trabalho } \\
\text { predominante }\end{array}$ & $\begin{array}{c}\text { Diferenciação } \\
\text { entre conselho e } \\
\text { diretoria }\end{array}$ & $\begin{array}{c}\text { Resultados } \\
\text { atribuíveis ao } \\
\text { conselho/diretor } \\
\text { ia }\end{array}$ & Destaques \\
\hline 5 & 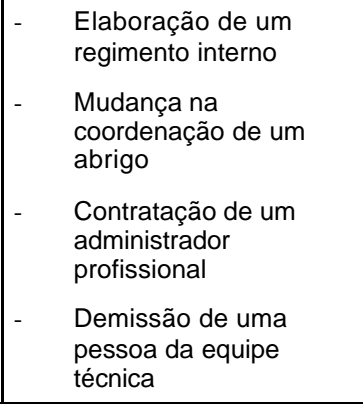 & $\begin{array}{l}\text { Apoiador, } \\
\text { facilitador, } \\
\text { mediador }\end{array}$ & $\begin{array}{l}\text { Reuniões regulares, } \\
\text { ouvir mais de uma } \\
\text { pessoa antes de } \\
\text { decidir, franqueza, } \\
\text { visitas regulares à } \\
\text { entidade, reconhecer } \\
\text { esforços, tomada } \\
\text { coletiva de decisões }\end{array}$ & $\begin{array}{l}\text { Alta -a } \\
\text { conselheira } \\
\text { entrevistada é a } \\
\text { principal } \\
\text { fundadora da } \\
\text { organização }\end{array}$ & $\begin{array}{l}\text { Um pouco mais formal, } \\
\text { distanciado do dia-a-dia }\end{array}$ & $\begin{array}{l}\text { Muito fraca - o } \\
\text { conselho é pouco } \\
\text { ativo }\end{array}$ & \begin{tabular}{|l} 
Manutenção do \\
administrador, \\
adoção de \\
princípios mais \\
"empresariais" de \\
trabalho
\end{tabular} & $\begin{array}{l}\text { A conselheira } \\
\text { fundadora e o } \\
\text { administrador } \\
\text { representam duas } \\
\text { culturas diferentes: } \\
\text { uma mais "social" e } \\
\text { outra mais } \\
\text { "empresarial" }\end{array}$ \\
\hline 7 & 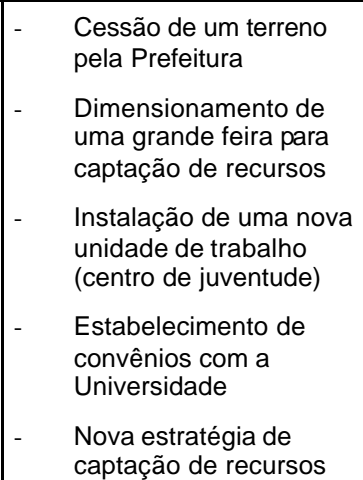 & $\begin{array}{l}\text { Apoiador, } \\
\text { aprovador, } \\
\text { "abridor de } \\
\text { portas" }\end{array}$ & $\begin{array}{l}\text { Reuniões regulares, } \\
\text { estabelecimento de } \\
\text { metas para o grupo, } \\
\text { visitas freqüentes à } \\
\text { entidade, decisão por } \\
\text { consenso, utilização de } \\
\text { parâmetros técnicos } \\
\text { nas suas análises, } \\
\text { busca de soluções (não } \\
\text { impedimentos), uso de } \\
\text { um projeto comum } \\
\text { como parâmetro para } \\
\text { decisões, visitas a } \\
\text { outras instituições }\end{array}$ & \begin{tabular}{|l|} 
Significativa - a \\
principal liderança \\
executiva é uma \\
das fundadoras \\
de uma nova fase \\
institucional, \\
iniciada logo após \\
a criação da \\
entidade
\end{tabular} & $\begin{array}{l}\text { Decisões coletivas, } \\
\text { esforços individuais, } \\
\text { informalidade }\end{array}$ & \begin{tabular}{|l|} 
Muito fraca - o \\
conselho consultivo \\
é pouco ativo e \\
alguns de seus \\
componentes se \\
misturam com a \\
diretoria
\end{tabular} & $\begin{array}{l}\text { Ampliação do } \\
\text { atendimento à } \\
\text { população, } \\
\text { captação de } \\
\text { recursos }\end{array}$ & $\begin{array}{l}\text { As lideranças são as } \\
\text { mesmas há } 30 \text { anos }\end{array}$ \\
\hline
\end{tabular}




\begin{tabular}{|c|c|c|c|c|c|c|c|c|}
\hline Entidade & $\begin{array}{c}\text { Tipos de questões em que } \\
\text { há envolvimento direto do } \\
\text { conselho }\end{array}$ & $\begin{array}{c}\text { Papel } \\
\text { predominante } \\
\text { do conselho/ } \\
\text { diretoria }\end{array}$ & $\begin{array}{l}\text { Principais práticas de } \\
\text { denotam } \\
\text { competências }\end{array}$ & $\begin{array}{l}\text { Influência de } \\
\text { fundadores }\end{array}$ & $\begin{array}{l}\text { Estilo de trabalho } \\
\text { predominante }\end{array}$ & $\begin{array}{l}\text { Diferenciação } \\
\text { entre conselho e } \\
\text { diretoria }\end{array}$ & $\begin{array}{c}\text { Resultados } \\
\text { atribuíveis ao } \\
\text { conselho/diretor } \\
\text { ia }\end{array}$ & Destaques \\
\hline 3 & $\begin{array}{l}\text { - } \quad \begin{array}{l}\text { Venda de uma casa } \\
\text { recebida em doação }\end{array} \\
\text { - } \quad \begin{array}{l}\text { Decisão de assumir uma } \\
\text { creche oferecida por } \\
\text { uma fundação }\end{array} \\
\text { - } \quad \begin{array}{l}\text { Aprovação do conse lho } \\
\text { fiscal }\end{array} \\
\text { - } \quad \begin{array}{l}\text { Aprovação do plano de } \\
\text { construção de um asilo }\end{array} \\
\text { - Distribuição de material } \\
\text { apreendido na } \\
\text { alfândega, recebido em } \\
\text { doação }\end{array}$ & $\begin{array}{l}\text { Operacional, } \\
\text { aprovador, } \\
\text { responsivo æ̀ } \\
\text { demandas da } \\
\text { diretoria }\end{array}$ & $\begin{array}{l}\text { Perguntas } \\
\text { esclarecedoras, visitas } \\
\text { freqüentes à entidade, } \\
\text { grande entendimento } \\
\text { das tradições, da } \\
\text { história e dos valores } \\
\text { institucionais, contato } \\
\text { direto com a equipe } \\
\text { técnica e com o } \\
\text { público-alvo da } \\
\text { entidade }\end{array}$ & \begin{tabular}{|l} 
Existente - as \\
fundadoras que \\
ainda atuam na \\
entidade \\
contribuem mais \\
simbolicamente \\
para a \\
preservação da \\
tradição \\
institucional
\end{tabular} & $\begin{array}{l}\text { Envolvimento individual } \\
\text { em atividades } \\
\text { operacionais de setores } \\
\text { específicos, como } \\
\text { bazares e confecção de } \\
\text { roupas; relacionamento } \\
\text { informal e amigo, deixa- } \\
\text { se conduzir pela } \\
\text { presidente da diretoria, a } \\
\text { quem mantém -se } \\
\text { disponível }\end{array}$ & $\begin{array}{l}\text { Clara - o conselho } \\
\text { mantém-se à } \\
\text { distância, a } \\
\text { diretoria governa a } \\
\text { entidade, dando } \\
\text { suporte e diretrizes } \\
\text { àsuperintendente, } \\
\text { que atua como } \\
\text { diretora executiva }\end{array}$ & $\begin{array}{l}\text { Manutenção da } \\
\text { cultura } \\
\text { institucional, } \\
\text { motivação de } \\
\text { voluntárias e } \\
\text { reforço do senso } \\
\text { de comunidade } \\
\text { que existe em } \\
\text { torno da entidade }\end{array}$ & $\begin{array}{l}\text { Essa organização se } \\
\text { utiliza muito de } \\
\text { voluntárias, que } \\
\text { mantêm a ligação } \\
\text { com a entidade até } \\
\text { mesmo por gerações } \\
\text { dentro de uma } \\
\text { mesma família }\end{array}$ \\
\hline 2 & 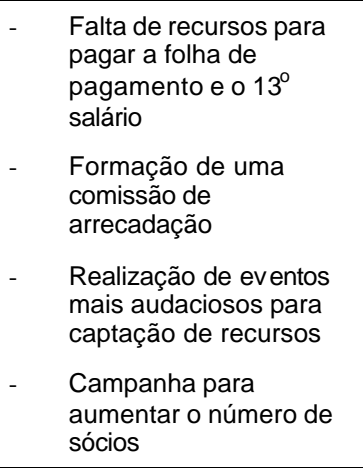 & $\begin{array}{l}\text { Aprovador, } \\
\text { operacional, } \\
\text { apoiador }\end{array}$ & $\begin{array}{l}\text { Estabelecimento de } \\
\text { metas, estudo regular } \\
\text { de um referencial } \\
\text { comum (doutrina } \\
\text { espírita), visitas } \\
\text { constantes à entidade } \\
\text { ou ao Centro Espírita, } \\
\text { participação em cursos }\end{array}$ & \begin{tabular}{|l|} 
Alta -os \\
voluntários do \\
conselho diretor e \\
da diretoria \\
mostram um \\
respeito muito \\
grande pelo papel \\
da fundadora \\
entrevistada, \\
reconhecendo \\
seu papel legítimo \\
de liderança \\
institucional
\end{tabular} & \begin{tabular}{|l} 
"Faz de tudo", atuação \\
baseada em comissões e \\
esforços individuais, \\
relacionamento informal, \\
sensível a situações \\
emergenciais
\end{tabular} & $\begin{array}{l}\text { Fraca - a } \\
\text { administração e o } \\
\text { governo da } \\
\text { organização estão } \\
\text { àcargo da } \\
\text { diretoria; o } \\
\text { conselho parece } \\
\text { ser importante } \\
\text { como grupo de } \\
\text { apoio e como } \\
\text { recurso: trabalho } \\
\text { voluntário, } \\
\text { conhecimento } \\
\text { técnico e contatos } \\
\text { pessoais }\end{array}$ & $\begin{array}{l}\text { Superação de } \\
\text { situações } \\
\text { financeiras } \\
\text { críticas }\end{array}$ & $\begin{array}{l}\text { A doutrina espírita } \\
\text { atua como fator } \\
\text { agregador das } \\
\text { pessoas. } \\
\text { O trabalho técnico é } \\
\text { realizado por uma } \\
\text { equipe de } \\
\text { profissionais } \\
\text { contratados. }\end{array}$ \\
\hline 10 & $\begin{array}{l}\text { - } \quad \text { Criação de uma pré- } \\
\text { escola } \\
\text { - } \quad \begin{array}{l}\text { Abertura de um } \\
\text { departamento de } \\
\text { marketing }\end{array} \\
\text { - } \quad \begin{array}{l}\text { Realização de uma } \\
\text { feijoada }\end{array} \\
\text { - } \quad \text { Falta de dinheiro }\end{array}$ & $\begin{array}{l}\text { Opinativo, } \\
\text { passivo, } \\
\text { submisso }\end{array}$ & $\begin{array}{l}\text { Convivência regular (no } \\
\text { Centro Espírita), } \\
\text { contato direto com o } \\
\text { público-alvo }\end{array}$ & $\begin{array}{l}\text { Alta - a liderança } \\
\text { executiva tem } \\
\text { uma relação } \\
\text { quase de } \\
\text { fundadora com a } \\
\text { instituição, como } \\
\text { "mãe da casa" }\end{array}$ & $\begin{array}{l}\text { Informal, pontual, } \\
\text { emergencial, específico, } \\
\text { individual, preocupado } \\
\text { com manutenção, } \\
\text { preservação e segurança }\end{array}$ & $\begin{array}{l}\text { Fraca - não há } \\
\text { uma relação plena } \\
\text { de parceria entre } \\
\text { conselho e } \\
\text { diretoria; a diretoria } \\
\text { executiva } \\
\text { administra a } \\
\text { entidade e o } \\
\text { conselho quase } \\
\text { que submete-se a } \\
\text { ela }\end{array}$ & $\begin{array}{l}\text { Solução de } \\
\text { problemas } \\
\text { emergenciais, } \\
\text { maior venda de } \\
\text { convites para } \\
\text { eventos }\end{array}$ & $\begin{array}{l}\text { A liderança } \\
\text { executiva está nesta } \\
\text { posição há } 17 \text { anos. } \\
\text { A maioria dos } \\
\text { conselheiros tem } \\
\text { mais de } 70 \text { anos. }\end{array}$ \\
\hline
\end{tabular}




\begin{tabular}{|c|c|c|c|c|c|c|c|c|}
\hline Entidade & $\begin{array}{l}\text { Tipos de questões em que } \\
\text { há envolvimento direto do } \\
\text { conselho }\end{array}$ & $\begin{array}{c}\text { Papel } \\
\text { predominante } \\
\text { do conselho/ } \\
\text { diretoria }\end{array}$ & $\begin{array}{l}\text { Principais práticas de } \\
\text { denotam } \\
\text { competências }\end{array}$ & $\begin{array}{l}\text { Influência de } \\
\text { fundadores }\end{array}$ & $\begin{array}{l}\text { Estilo de trabalho } \\
\text { predominante }\end{array}$ & $\begin{array}{l}\text { Diferenciação } \\
\text { entre conselho e } \\
\text { diretoria }\end{array}$ & $\begin{array}{c}\text { Resultados } \\
\text { atribuíveis ao } \\
\text { conselho/diretor } \\
\text { ia }\end{array}$ & Destaques \\
\hline 8 & $\begin{array}{l}\text { - } \quad \begin{array}{l}\text { Mudança do papel do } \\
\text { conselho }\end{array} \\
\text { - } \quad \begin{array}{l}\text { Mudança de modelo } \\
\text { organizacional }\end{array}\end{array}$ & $\begin{array}{l}\text { Propositivo, } \\
\text { controlador, } \\
\text { definidor de } \\
\text { rumos, } \\
\text { estratégico }\end{array}$ & $\begin{array}{l}\text { Encontros para } \\
\text { entender a fundação, } \\
\text { discussão de rumos a } \\
\text { tomar, trazer novas } \\
\text { pessoas, forma mais } \\
\text { estruturada de colocar } \\
\text { questões para o } \\
\text { conselho, discussão de } \\
\text { temas com } \\
\text { especialistas externos, } \\
\text { formulação de questões } \\
\text { abrangentes, reuniões } \\
\text { regulares, contato } \\
\text { direto com a equipe } \\
\text { gestora, preocupação } \\
\text { com a } \\
\text { representatividade do } \\
\text { conselho }\end{array}$ & $\begin{array}{l}\text { Existente -o } \\
\text { principal } \\
\text { idealizador até } \\
\text { hoje se mantém } \\
\text { presente entre as } \\
\text { lideranças da } \\
\text { organização }\end{array}$ & $\begin{array}{l}\text { Estratégico, formal, } \\
\text { estruturado, distanciado, } \\
\text { empresarial, atento a } \\
\text { aspectos de gestão, com } \\
\text { forte influência do diretor } \\
\text { presidente, valorização } \\
\text { de esforços individuais }\end{array}$ & $\begin{array}{l}\text { Existente -com o } \\
\text { passar do tempo, } \\
\text { ficou claro para as } \\
\text { lideranças que } \\
\text { "uma série de } \\
\text { questões } \\
\text { operacionais não } \\
\text { podiam mais ser } \\
\text { levadas ao } \\
\text { conselho de } \\
\text { administração, que } \\
\text { passou a assumir } \\
\text { uma questão mais } \\
\text { estratégica". } \\
\text { "O conselho se } \\
\text { preocupa com } \\
\text { linhas de trabalho", } \\
\text { enquanto a } \\
\text { diretoria faz o } \\
\text { acompanhamento } \\
\text { da gestão } \\
\text { institucional e dá } \\
\text { suporte à equipe } \\
\text { gerencial. }\end{array}$ & $\begin{array}{l}\text { Renovação do } \\
\text { conselho, } \\
\text { desenvolvimento } \\
\text { institucional, } \\
\text { redefinição de } \\
\text { rumos } \\
\text { estratégicos }\end{array}$ & $\begin{array}{l}\text { A fundação cresceu } \\
\text { rapidamente nos } \\
\text { últimos anos, } \\
\text { passando de } 10 \text { para } \\
\text { mais de } 70 \text { pessoas } \\
\text { trabalhando nela } \\
\text { atualmente. }\end{array}$ \\
\hline 9 & 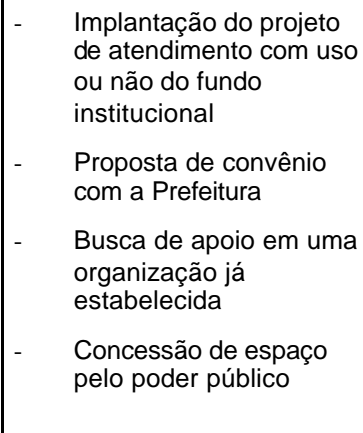 & $\begin{array}{l}\text { Simbólico, } \\
\text { apoiador }\end{array}$ & $\begin{array}{l}\text { Consulta a } \\
\text { especialistas, } \\
\text { processos decisórios } \\
\text { lentos, amadurecendo } \\
\text { decisões, revisão de } \\
\text { decisões do passado } \\
\text { em questões atuais, } \\
\text { assumir } \\
\text { responsabilidade por } \\
\text { riscos, discussão de } \\
\text { pontos de vista } \\
\text { diferentes, colocar-se } \\
\text { no lugar da comunidade }\end{array}$ & $\begin{array}{l}\text { Alta - a liderança } \\
\text { entrevistada do } \\
\text { conselho curador } \\
\text { é o principal } \\
\text { instituidor da } \\
\text { entidade }\end{array}$ & $\begin{array}{l}\text { Informal, a-sistemático, } \\
\text { muito influenciado pelo } \\
\text { carisma do instituidor, } \\
\text { vínculos pessoais, fala- } \\
\text { se diretamente, mas } \\
\text { reúne-se pouco, ações } \\
\text { individuais, decisões } \\
\text { grupais }\end{array}$ & $\begin{array}{l}\text { Inexistente-na } \\
\text { prática existe um } \\
\text { pequeno grupo de } \\
\text { voluntários, } \\
\text { liderado pelo } \\
\text { instituidor que } \\
\text { comanda a } \\
\text { fundação }\end{array}$ & $\begin{array}{l}\text { Implantação do } \\
\text { primeiro projeto } \\
\text { institucional, } \\
\text { amadurecimento } \\
\text { do desenho } \\
\text { institucional }\end{array}$ & $\begin{array}{l}\text { O desenho da } \\
\text { organização foi feito } \\
\text { com a participação } \\
\text { dos dois } \\
\text { entrevistados, nos } \\
\text { últimos } 3 \text { anos - o } \\
\text { conselheiro tem sido } \\
\text { o responsável pela } \\
\text { iniciativa, enquanto a } \\
\text { executiva tem } \\
\text { aparentemente } \\
\text { exercido um papel } \\
\text { mais técnico- } \\
\text { gerencial }\end{array}$ \\
\hline
\end{tabular}




\begin{tabular}{|c|c|c|c|c|c|c|c|c|}
\hline Entidade & $\begin{array}{l}\text { Tipos de questões em que } \\
\text { há envolvimento direto do } \\
\text { conselho }\end{array}$ & $\begin{array}{c}\text { Papel } \\
\text { predominante } \\
\text { do conselho/ } \\
\text { diretoria }\end{array}$ & $\begin{array}{l}\text { Principais práticas de } \\
\text { denotam } \\
\text { competências }\end{array}$ & $\begin{array}{c}\text { Influência de } \\
\text { fundadores }\end{array}$ & $\begin{array}{l}\text { Estilo de trabalho } \\
\text { predominante }\end{array}$ & $\begin{array}{l}\text { Diferenciação } \\
\text { entre conselho e } \\
\text { diretoria }\end{array}$ & $\begin{array}{c}\text { Resultados } \\
\text { atribuíveis ao } \\
\text { conselho/diretor } \\
\text { ia }\end{array}$ & Destaques \\
\hline 6 & 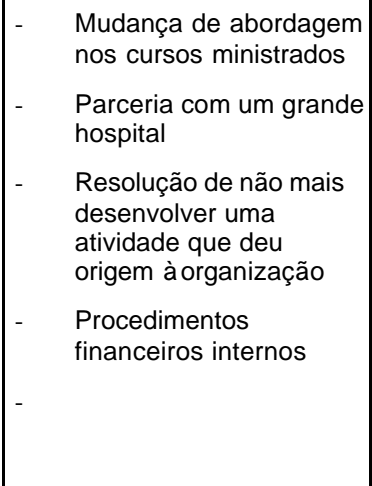 & $\begin{array}{l}\text { Apoiador, } \\
\text { decisório, } \\
\text { delegador, } \\
\text { governador }\end{array}$ & $\begin{array}{l}\text { Comitês, delegação de } \\
\text { responsabilidade, } \\
\text { contato direto com } \\
\text { equipe técnica, } \\
\text { acompanhamento } \\
\text { regular das atividades, } \\
\text { decisão baseada na } \\
\text { argumentação, auto- } \\
\text { avaliação da foma de } \\
\text { atuar do conselho, mais } \\
\text { de uma reunião para } \\
\text { analisar um assunto } \\
\text { importante, franqueza, } \\
\text { comentários sobre o } \\
\text { desempenho uns para } \\
\text { os outros }\end{array}$ & $\begin{array}{l}\text { Existente, porém } \\
\text { não tão } \\
\text { predominante } \\
\text { quanto antes }\end{array}$ & $\begin{array}{l}\text { Os conselheiros atuam } \\
\text { em conjunto nas } \\
\text { reuniões e } \\
\text { separadamente em } \\
\text { comitês; para } \\
\text { encaminhamento de } \\
\text { assuntos mais } \\
\text { específicos e } \\
\text { operacionais é delegada } \\
\text { autoridade aos } \\
\text { conselheiros, em áreas } \\
\text { pré-determinadas pelo } \\
\text { conjunto; voltado para o } \\
\text { futuro; coragem, } \\
\text { humildade e franqueza }\end{array}$ & $\begin{array}{l}\text { Clara - o conselho } \\
\text { vem assumindo } \\
\text { uma liderança mais } \\
\text { constitucional e a } \\
\text { diretoria tem um } \\
\text { papel organizador e } \\
\text { estruturador (a } \\
\text { coordenadora } \\
\text { exerce uma } \\
\text { liderança técnica) }\end{array}$ & $\begin{array}{l}\text { Redirecionament } \\
\text { o da entidade, } \\
\text { equilíbrio de } \\
\text { tensões internas } \\
\text { entre lideranças, } \\
\text { mudança na } \\
\text { forma de atuar do } \\
\text { conselho, } \\
\text { ampliação do } \\
\text { leque de } \\
\text { parcerias, } \\
\text { incremento na } \\
\text { qualidade dos } \\
\text { cursos oferecidos }\end{array}$ & $\begin{array}{l}\text { Ambos os } \\
\text { entrevistados foram } \\
\text { recrutados para a } \\
\text { organização }\end{array}$ \\
\hline
\end{tabular}




\subsection{Considerações FinaIs e Recomendações}

O propósito deste estudo, conforme enunciado no início deste documento, é ampliar o conhecimento sobre a atuação dos conselhos das organizações da sociedade civil em São Paulo. Especificamente, procura-se responder à questão "Nas condições brasileiras, como devem trabalhar os conselhos diretores das organizações da sociedade civil?".

O desenho dapesquisa foi orientado por três etapas:

(a) Examinar as práticas de atuação dos conselhos considerados mais eficazes pela literatura especializada;

(b) Conhecer como operam os conselhos das organizações da sociedade civil paulistas que atendem crianças e adolescentes;

(c) Caracterizar o comportamento de conselhos eficazes nas condições brasileiras.

A síntese de cada uma dessas etapas, bem como um conjunto de recomendações essenciais é apresentada nos sub-itens seguintes.

Todas estas considerações e recomendações devem ser consideradas à luz das limitações deste estudo apresentadas no final deste trabalho.

\subsubsection{Principais RecomendaÇÕes da literatura esPeCIALIZADA}

O estudo da literatura especializada em conselhos, especialmente aquela de língua inglesa, permite concluir que o tema da governança institucional pode ser abordado a partir do conselho por pelo menos quatro maneiras diferentes: do ponto de vista estrutural, pela definição de políticas, de uma forma contingencial (baseada em responsabilidades) e de uma forma comportam ental (baseada em competências).

Os aspectos estruturais são considerados importantes como condicionantes - limitadores ou potencializadores - da atuação do conselho. Dentre os principais elementos estruturais estudados estão: o perfil do conselheiro, a composição e o tamanho do conselho, a duração dos mandatos e a organização interna.

A principal conclusão a que se pode chegar examinando as referências quanto aos aspectos estruturais é que eles normalmente são negligenciados e somente poderão criar condições favoráveis ao desempenho do conselho se tratados sistemática e conscientemente. Uma boa parte das dificuldades estruturais advém do pouco caso ou da pouca ousadia dos conselhos em responsabilizar-se pelas suas próprias condições de funcionamento.

De maneira geral, os conselhos devem definir explícita e claramente que tipo de pessoas podem ser conselheiras e assegurar-se de ir em busca delas, fortalecendo seu interesse pela organização e conscientizando-as da importância do seu papel no conselho. O consel ho precisa ter em mente, também, que um bom novo conselheiro não é meramente fruto de uma boa escolha, mas de um processo de recrutamento e orientação sistemático que exige tempo e participação dos conselheiros atuais.

Em termos de composição do conselho œmo um todo, atenção precisa ser dada tanto à diversidade, como à representatividade. Uma composição diversificada e heterogênea pode favorecer o surgimento de pontos 
de vista diferentes e enriquecer as discussões internamente. Um conselho de pessoas iguais corre o risco de ficar confortável, porém pouco criativo e limitado a um certo conjunto de idéias e alternativas de ações.

A representatividade do conselho como um todo - e não dos seus membros individualmente - é considerada fundamental para que a organização mantenha-se vinculada (e não subordinada) aos principais constituintes organizacionais, bem como estabeleça as bases de uma governança transparente, democrática e responsável. O grau de representatividade adequado depende do correto mapeamento destes constituintes, que necessita ser feito de tempos em tempos.

Duas das variáveis estruturais mais comumente definidas em estatuto são o tamanho do conselho e o mandato dos conselheiros. O tamanho pode variar, sendo impossível pré-determinar um tamanho ideal para todas as situações. Conselhos grandes dificultam a tomada de decisões colegiadas e conselhos pequenos podem ser insuficientes para cumprirem suas responsabilidades. Os mandatos também podem variar, evidentemente - deve-se evitar, porém, mandatos muito curtos (um ano, por exemplo), que dificultam que algo realmente efetivo possa ser desenvolvido, e mandatos muito longos, sob pena de prejudicar a renovação da mentalidade institucional. Uma pergunta que os conselheiros individualmente e o conselho como um todo devem fazer, explicitamente, é: "Quando é hora de sair?".

Em termos de organização interna, os conselhos devem prever: papéis individuais, grupos de trabalho (comitês) e reuniões gerais. Estes itens precisam ser desenhados de forma a favorecer a atuação do conselho como um todo e não substitui-lo, como pode acontecer. Papéis individuais, comitês e reuniões são instâncias de trabalho do conselho em que ele exerce seu papel, com características diferentes especialmente nos dois primeiros casos é preciso considerar que o poder não pode ser exercido individual ou isoladamente, a não ser que expressamente delegado pelo conselho. Estas instâncias necessitam ser integradas entre si por uma política e um sistema de comunicação eficaz, sob pena de ameaçar a totalidade do conselho.

Uma vez definidas, ou melhor, construídas as condições estruturais para o conselho trabalhar, a atenção volta-se para o exercício prático do seu papel. Não há receitas sobre como todos os conselhos devem operar, nem tampouco regras absolutas sobre como devem funcionar os conselhos de todas as organizações. A revisão da literatura especializada indica que a atuação do conselho pode se orientar por pelo menos três elementos: políticas, responsabilidades e competências.

Considerando que políticas sempre existem, implícitas ou explícitas, nas mais diversas circunstâncias da atividade organizacional, o conselho precisa aprender a identificar, avaliar e propor políticas de maneira a participar e liderar o governo de uma organização da sociedade civil. De alguma forma, qualquer decisão do conselho pode ser avaliada quanto ao impacto sobre políticas institucionais, que compõem pelo menos quatro grandes grupos: aquelas relativas à finalidade e ao propósito da entidade, aos meios pelos quais a organização busca realizar este propósito, às relações entre as diversas instâncias institucionais e ao processo de governança como um todo (incluindo o próprio funcionamento do conselho).

Ao raciocinar por políticas, o conselho pode evitar intrometer-se demais em aspectos operacionais, bem como manter um bom grau de relevância (para a organização) nas suas discussões; além disso, pode dar espaço para a criatividade e inovação nos demais grupos da entidade. Um bom conjunto de políticas 
precisa ser explícito, literal, disponível, curto, inclusivo, atual e compartilhado. Pode ainda ser prescritivo, indicando como deve se comportar a organização, ou restritivo, indicando aquilo que não se deve fazer.

Porém, é ingenuidade supor que a concentração do trabalho do conselho somente em políticas pode ser suficiente para atender à necessidade de todas as organizações de um setor tão diversificado quanto o terceiro setor. Ao contrário, é preciso considerar que cada organização tem uma necessidade específica, que muda com o passar do tempo. O conselho precisará saber diagnosticar esta necessidade e assumir determinadas responsabilidades adequadas àquela contingência específica.

O conselho deve, portanto, estar também preparado para assumir determinadas responsabilidades diferentes das responsabilidades de quaisquer outras instâncias organizacionais. Ao deixar suas responsabilidades explícitas o conselho pode organizar-se para cumpri-las, traçar um plano de trabalho e avaliar seu próprio desempenho.

A literatura es pecializada sugere que o conselho é responsável, em geral, por: fortalecer a missão, a visão e os objetivos da organização, assegurar que os programas e serviços organizacionais estejam alinhados a estes objetivos, promover a comunicação da entidade com seus vários públicos, zelar pela imagem da instituição, garantir o adequado provimento e aplicação dos recursos, assegurar integridade ética e legal e transparência da organização, selecionar e apoiar a liderança executiva, recrutar e orientar novos conselheiros e melhorar o desempenho do próprio conselho.

O exercício destas responsabilidades pode e deve variar, exigindo que o conselho analise e reflita sobre a situação em que se encontra, bem como sobre o passado institucional e as perspectivas de futuro. Num processo contínuo e dinâmico de reflexão, organização e também de ação, deve levantar para si questões relativas a cada uma das suas responsabilidades, esperando-se que obtenha respostas que o permitam:

- Concentrar-se em questões cruciais, críticas e centrais para o desempenho institucional;

- $\quad$ Orientar -se para resultados;

- Definir medidas claras de sucesso;

- Mobilizar constituintes internos e externos àorganização.

O conselho pode realizar tudo isso descrito até aqui de uma forma mais ou menos competente. Ocupar um papel de liderança organizacional, influenciar a definição de políticas efetivas interna e externamente e assumir o conjunto descrito de responsabilidades é uma tarefa que exige um conjunto razoável de competências, tanto relativas ao conteúdo das questões, quanto æ̀s relações que se estabelecem e quanto ao próprio processo de trabalho do conselho.

Neste trabalho foram identificadas 6 competências básicas que diferenciam os conselhos mais eficazes daqueles menos eficazes. Estas competências dizem respeito ao conselho como um todo e não a um ou outro conselheiro individualmente; e precisam ser constantemente desenvolvidas e aprimoradas, uma vez que praticamente nenhum grupo as exerce plenamente. São elas:

- Competência analítica: diz respeito à capacidade de dissecar problemas complexos, perceber sutilezas e trabalhar com múltiplas perspectivas para encontrar respostas apropriadas a diferentes situações. Conselhos eficazes utilizam uma perspectiva institucional ampla, buscam informações ativamente e 
levantam dúvidas, provocando a emergência de diferentes pontos de vista, tolerando ambigüidades e reconhecendo que raramente produzem-se soluções ideais e eternas.

- Competência contextual: refere-se à habilidade do conselho de aprender, compreender e considerar a cultura e as tradições da organização a que faz parte. Um conselho competente nesta dimensão adapta-se às características do ambiente organizacional em que está, apoia -se na missão e nos valores da entidade para tomar decisões e age de forma a exemplifica r e fortalecer a identidade institucional.

- Competência educacional: um conselho competente neste aspecto toma as providências necessárias para assegurar que os conselheiros mantenham-se bem informados e atualizados sobre a instituição e sobre o papel, as responsabilidades e o desempenho do conselho. Um conselho competente considerase aprendiz e mestre de si próprio, conscientemente criando oportunidades para sua educação, solicitando comentários e críticas de outros sobre seu trabalho e retirando-se regularmente para reflexão e auto -análise.

- Competência estratégica: reflete a habilidade de definir o direcionamento da entidade. Um conselho considerado estrategicamente competente trabalha de forma a clarear e aprimorar as prioridades institucionais e assegurar uma abordagem estratégica ao futuro da organização, focando em temas significativos e procurando resolver problemas antes que se tornem urgentes. Além disso, organiza-se de acordo e ao redor destas prioridades.

- Competência interpessoal: uma vez que conselhos são, de fato, grupos, precisam cuidar do seu desenvolvimento como tal, favorecendo o bem estar de cada membro e criando um clima de coesão. Conselhos competentes neste aspecto geralmente criam um ambiente inclusivo, definem metas para si próprios e preparam pessoas para futuras posições de liderança.

- Competência política: a habilidade política está relacionada ao desenvolvimento e manutenção de relações positivas entre os constituintes essenciais da organização. O conselho competente é aquele que constrói relações cooperativas, respeita os papéis legítimos de outros atores, procura garantir a integridade do processo de governança, consulta e comunica-se com freqüência e diretamente com audiências externas e adota uma postura ganhaganha nas situações mais tensas.

Essas quatro dimensões - estrutura, políticas, responsabilidades e competências - não são incompatíveis entre si, embora alguns autores recomendem que o conselho se fixe a uma delas. Seu conhecimento amplia o leque de possibilidades de trabalho do conselho e permite que possa responder às exigências de cada entidade e sociedade de maneira mais eficaz.

\subsubsection{COMO OPERAM OS CONSELHOS DAS OSCS PAULISTAS QUE ATENDEM CRIANÇAS E ADOLESCENTES}

O exame dos estatutos das organizações da Rede Nossas Crianças, bem como o conhecimento e análise de casos práticos de 10 organizações diferentes contribuiu para caracterizar como atuam os conselhos de organizações da sociedade civil em São Paulo. Esta caracterização é feita a seguir, procurando destacar aquilo que é predominante e não a exceção. 
Analisando primeiramente os aspectos estruturais, chega-se à conclusão que os conselhos são compostos por pessoas com mais de 40 anos, com alguma formação superior, que estão há anos em contato com a entidade e que têm em comum uma identificação pessoal com a causa e com a filosofia institucional. Em 6 dos 10 casos estudados, os conselheiros estão presentes desde a fase inicial da organização, caracterizando-se como grupo fundador, com graus variáveis de atividade. Em 4 casos foram convidados por outrem a fazer parte dos conselhos. Em geral, são pessoas que por circunstâncias diversas têm uma entrada financeira estável (não necessariamente alta), podendo se ocupar de meio período a dois dias por semana com trabalho voluntário para a entidade.

Uma parte significativa dos conselheiros é trazida para a instituição pelo convívio com outros conselheiros em atividades paralelas àentidade, como centros espíritas e igrejas.

Em termos de composição, alguns conselhos manifestaram espontaneamente dar valor à diversidade, destacando principalmente a formação e atividade profissional dos seus membros. Quase nada foi mencionado a respeito de gênero, idade ou etnia. A valorização de uma faixa de renda mais alta parece ser sutilmente valorizada. O quesito representatividade é praticamente desconsiderado na composição dos conselhos, indicando uma atenção maior aos aspectos legal e funcional para a formação dos grupos. Por causa disso, fica-se com a impressão de que o grande determinador da composição dos conselhos das organizações da sociedade civil estudadas é o vínculo com os fundadores e o processo histórico institucional - não se pode atribuir esta composição a processos sistemáticos permanentes de seleção, recrutamento e orientação dos membros.

Os conselhos das organizações da sociedade civil paulistas variam em tamanho, havendo conselhos grandes e conselhos pequenos. A opção por conselhos maiores parece estar vinculada a um caráter mais simbólico destes, enquanto que a escolha por conselhos menores denota uma preocupação mais funcional. $\mathrm{Na}$ prática, os dados da pesquisa sugerem que os conselhos mais ativos têm entre 5 e 10 pessoas, em média, caracterizando um grupo de trabalho. Este número parece ser importante para garantir um certo nível de informalidade nas relações e nos procedimentos; números maiores prejudicam as reuniões e exigem procedimentos mais sistemáticos de trabalho.

Sobre mandatos, a maioria das organizações é bastante flexível com reeleições e reconduções, mantendo seus conselheiros por vários anos. Pelos estatutos, entretanto, a maioria das organizações utiliza mandatos de 2 ou 3 anos.

Quanto à organização interna, as referências a comitês ou comissões são poucas, sugerindo que os conselhos utilizam-se principalmente de reuniões e atvidades individuais. A freqüência de reuniões pode ser considerada alta, de mensais a bimensais, mas exige levar em consideração que em vários casos conselho e diretoria se misturam na prática.

Sobre o conteúdo do trabalho dos conselhos estudados, chega-se à conclusão que há uma enorme variação nos tipos de problemas com os quais tratam os conselhos, indo desde assuntos bastante específicos até questões de identidade institucional. Preocupações financeiras estão regularmente presentes nas pautas de discussão da maioria dos conselhos e denotam uma dificuldade em tornar suas organizações minimamente estáveis. Questões relativas a investimentos vultosos, mobilização de patrimônio e riscos também geralmente são trazidas à mesa do conselho. É raro, entretanto, encontrar 
conselhos trabalhando somente em políticas institucionais; os que o fazem concentram-se em prioridades. A identidade institucional é pouco discutida formalmente, predominando a solução de problemas e a aprovação de propostas dos fundadores ou da Iderança executiva. Tampouco questões técnicas são trazidas para serem discutidas pelos conselheiros.

Os conselheiros estão "impregnados" pela cultura institucional, na maioria dos casos, devido principalmente à convivência social e à interação intensa com os fundadores, o que determina a existência de uma linguagem comum. Pouquíssimos entrevistados foram capazes de identificar erros cometidos pelos conselhos de suas instituições, revelando que estes grupos não realizam este tipo de reflexão. $O$ uso de indicadores de desempenho institucional como parâmetro foi detectado em poucos casos, bem como o uso formal de um plano institucional, denotando uma precária "solução de continuidade" nas discussões dos conselhos.

Quanto às práticas de operação, percebe-se que maioria dos conselhos não têm o hábito de fazer perguntas nos seus processos de análise de problemas; perguntas são usadas no máximo para obter informações. As discussões na maioria dos conselhos são baseadas em recomendações da equipe executiva e nas opiniões emitidas pelos conselheiros, aparentemente procurando encontrar a que melhor se aplique à situação. Poucos conselhos têm o hábito de consultar pessoas de fora da organização e trazer especialistas ou lideranças externas para discussão. Apesar disso, o voto é muito pouco usado nas resoluções - predomina a discussão a argumentação e a busca de consenso para as decisões.

A transmissão da cultura, dos valores, das tradições e da filosofia institucional é feita pessoa a pessoa, informalmente, em quase todas as entidades. Constituem exceções os exemplos de ações concretas e sistemáticas para a educação e auto -avaliação do desempenho dos conselheiros; a maioria dos esforços neste sentido é individual e orientada primariamente ao conteúdo da causa institucional (e não ao processo de trabalho do conselho). Nenhum conselho sequer cogitou a realização de um retiro ou uma reunião mais prolongada para discutir algum assunto ligado àgovernança institucional.

A comunicação entre os conselheiros se dá prioritariamente através das reuniões e do contato pessoal, havendo poucos mecanismos formais adotados, a não ser a ata das reuniões. A comunicação com a instituição é facilitada pelo fato de haver diversos casos de envolvimento de conselheiros em atividades práticas operacionais nas entidades, num caráter mais de voluntário do que de conselheiro. Essa parece ser uma das principais formas encontradas para aproveitar o potencial dos conselheiros das organizações da sociedade civil participantes do estudo. Alguns conselhos estabelecem metas para si próprios, que têm um efeito bastante benéfico na moral destes grupos e no resultado organizacional.

O processo de recrutamento, renovação, sucessão e formação de novas lideranças é informal, não sistemático e baseado no bom senso em quase todas as instituições, denotando pouca dedicação a isso na maioria dos casos. Predominam, como já foi dito, conselheiros e diretores com vínculos de muitos anos com suas entidades.

Quanto às relações, existe um pressuposto implícito na maioria das instituições de que o esforço voluntário não deve ser avaliado ou criticado. Foi pouco freqüente encontrar citações de conselheiros a respeito de críticas ou sugestões que tenham feito uns para os outros. As críticas que existem parecem ser 
compartilhadas "no corredor", de uma maneira fragmentada e indireta ou não existir. Elogios, entretanto, foram mais freqüentes.

As pessoas que atuam como lideranças executivas têm um papel central no desempenho das entidades e exercem influência direta sobre o desempenho dos conselhos. Os conselhos mostram reconhecer e respeitar a sua autonomia e autoridade sobre determinadas questões, predominando um relacionamento bastante cordial e baseado na confiança mútua.

As relações entre os conselheiros tendem a ser amigáveis e de respeito mútuo, havendo poucos casos em que os conselheiros são estranhos entre si. Na grande maioria das instituições os conselheiros e as lideranças executivas sentem-se à vontade para expressar suas opiniões uns para os outros e entre si. Não há indícios de haver uma relação hierárquica entre o conselho e demais instâncias institucionais, havendo, isto sim, um sentimento mais ou menos desenvolvido de co-responsabilidade pela instituição.

Alguns conselhos manifestaram uma preocupação em manter boas relações com órgãos públicos.

Finalmente, foi comum verificar que os termos "conselho" e "diretoria" têm significados diferentes para algumas organizações, enquanto em outras são utilizados com o mesmo sentido, apesar dos estatutos. Estes termos parecem não estar bem definidos e separados na cabeça das pessoas que trabalham nestas entidades, o que abre possibilidade para frustrações, desapontamentos e mal-entendidos. Alguns entrevistados literalmente usaram estes dois termos intercambiavelmente. Isso indica que a liderança do processo de governança institucional pode estar formalmente vinculada tanto ao conselho como à diretoria nas organizações da sociedade civil - e que os fundadores podem estar presentes em qualquer um dos grupos.

A importância dos conselhos para estas organizações varia em função do papel que assumem: conselhos "de papel", meramente aprovadores, são considerados de menor importância do que conselhos consultivos, apoiadores e governadores.

\subsubsection{QUANTO AO PROCESSO DE GOVERNANÇA INSTITUCIONAL}

Sobre o processo de governança institucional, a principal lição que se pode tirar é que ele é permeado por tensões, advindas da participação de diferentes atores em posições diversificadas de autoridade, responsabilidade, interesses e maturidade. Estas tensões fazem parte do processo de governança e devem ser identificadas e explicitadas para a compreensão do processo e a determinação das medidas de intervenção mais adequadas. Foram várias as tensões ou polaridades identificadas nesta pesquisa como presentes nos diversos processos de governança em que vivem as instituições estudadas: 
$\diamond \quad$ O caráter público versus o caráter privado de uma organização da sociedade civil;

$\diamond$ O problema específico versus o problema público;

$\diamond \quad$ A necessidade de controle, transparência e prestação de contas versus a demanda por liderança e responsabilidade fiduciária;

$\diamond \quad$ A busca de homogeneidade e harmonia versus a luta por preservar e manter um nível adequado de diversidade e diferenças de opinião;

$\diamond \quad \mathrm{O}$ trabalho coletivo versus o desempenho e a consciência individual;

४ A exigência de participação de associados e clientes versus o benefício do povo e da sociedade;

$\diamond \quad A$ demanda por um comportamento comprometido e engajado versus a idealização de uma postura de isenção, distanciamento e visão global para a tomada de decisões;

$\diamond \quad O$ controle interno versus o controle externo das entidades;

$\diamond \quad$ Um papel simbólico-políticolegal dos dirigentes versus um papel técnico-funcional da liderança gerencial;

$\diamond$ A mediação do ambiente interno æ̀ organizações versus uma concentraçãd em assuntos mais externos e ligados à coletividade;

$\diamond \quad \mathrm{O}$ conselho e a diretoria como um órgãos de gestão versus como arenas de exercício da cidadania;

$\diamond \quad$ A busca do ideal (ou do que quer vir a ser) social e organizacional versus o que é possível fazer e conseguir (o que é).

$\diamond \quad$ Um comportamento de apoiador versus um comportamento de carregador;

$\diamond$ Uma função de controle versus uma função de liderança;

$\diamond \quad$ Uma postura passiva versus uma postura proativa;

$\diamond \quad$ Uma visão de conjunto, do todo e das interrelações versus o foco em uma parte específica;

$\diamond \quad A$ ação coletiva e sinérgica versus a iniciativa individual;

々 Uma necessidade de centralização versus uma necessidade de descentralização;

$\diamond \quad$ Um perfil homogêneo versus um perfil heterogêneo dos diferentes grupos e equipes;

$\diamond \quad$ Uma contribuiç ão mais técnica versus uma contribuição mais simbólica dos dirigentes;

$\diamond \quad$ Um olhar de dentro para fora versus um olhar de fora para dentro dos diferentes atores;

$\diamond \quad$ Uma atitude consolidadora versus um impulso dinamizador das lideranças; $\diamond$ A cobrança versus o recomecimento dos esforços voluntários:

$\diamond \quad$ A crítica versus a devoção àquilo que já existe;

$\diamond \quad \mathrm{O}$ falar e dar palpites versus o fazer e dar exemplo;

$\diamond \quad \mathrm{O}$ foco no passado e no presente versus o foco no futuro;

$\diamond \quad$ Uma resposta terapêutica versus uma resposta pedagógica aos problemas do momento;

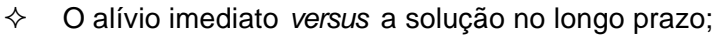

$\diamond \quad$ A ênfase em atender a demanda versus o estímulo por provocar a oferta;

$\diamond \quad$ O convívio com o velho versus o convívio com o novo;

$\diamond \quad$ Uma tendência de crescimento versus uma tendência de envelhecimento;

$\diamond \quad$ Uma cultura empresarial, focada em resultados versus uma cultura social, focada nos processos e relações;

$\diamond \quad \mathrm{O}$ uso de perguntas versus o exame de respostas;

$\diamond \quad$ Uma composição masculina versus uma composição feminina;

$\diamond \quad$ A demanda por quantidade versus a exigência por qualidade;

$\diamond \quad$ Uma postura de aprender versus uma postura de empreender;

$\diamond \quad$ O processo de diferenciar versus o processo de integrar;

$\diamond \quad$ O regimento formal versus o relacionamento informal;

$\diamond \quad$ O hábito de submeter-se versus o hábito de controlar;

$\diamond \quad$ O processo de administrar versus o processo de governar. 
Uma hipótese que se pode levantar em função destas considerações é de que o impacto e a sustentabilidade de uma organização da sociedade civil na sociedade será tanto maior quanto melhor for conduzido o proces so de governança institucional.

No universo de organizações da sociedade civil paulistas, a governança estudada parece ser percebida somente no âmbito institucional, tendo-se pouca consciência ou dando-se pouca importância para a dimensão extra-organizacional da comunidade, das organizações parceiras, do estado, da sociedade mais ampla. Isso faz com que ela seja pensada isoladamente, esquecendo-se que ela pode ser planejada como uma função compartilhada pelos vários atores em interação com a entidade.

\subsubsection{O QUE É UM BOM CONSELHO NO BRASIL - UMA ORIENTAÇÃo, NÃO UMA RECEITA}

Ao invés de simplesmente dizer o que os conselhos das organizações da sociedade civil brasileiras deveriam ou poderiam fazer para melhorar seu próprio desempenho, procura-se estabelecer uma série de princípios orientadores para a ação. A opção por princípios baseia-se na busca de reconhecer a essência do trabalho do conselho e sua filosofia. O uso de princípios dá espaço para a criatividade e a inovação em cada situação, bem como busca fundar as bases para o exercício do papel de conselheiro no país.

Arriscase supor que o potencial de um conselho será mobilizado àmedida que as pessoas que o compõem desenvolverem a capacidade de aplicar estes princípios, consciente e sistematicamente, na sua própria prática. Os princípios apresentados a seguir representam, portanto, uma filosofia orientadora e uma atitude de trabalho relacionados ao papel de conselho exercido por pessoas comuns (e não necessariamente especialistas) no processo de governança institucional.

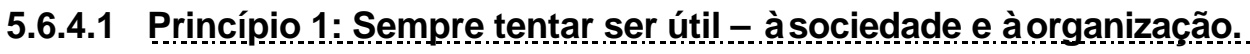

A decisão de criar ou a existência de um conselho em uma organização está baseada no pressuposto que ele pode ser útil. E a razão fundamental para a existência de uma OSC é a construção de uma sociedade melhor do que a atual - qualquer esforço terá sido em vão se não se conseguir obter resultados concretos primariamente fora da organização. Se não existir qualquer intenção em ser útil nem à sociedade, nem à organização, o conselho estará fadado ao insucesso. Qualquer participação do conselho em qualquer atividade relacionada àorganização deve ser percebida como útil àentidade e àsociedade.

Além de reconhecer honestamente suas motivações, isto implica, por parte do conselho e dos conselheiros reconhecer, em cada situação, o que pode ser e o que pode não ser "útil". O exercício construtivo do papel de conselho requer a intenção de melhorar a realidade social e organizacional e, a partir daí, decidir o que pode ser feito. Não necessariamente precisa-se saber o que fazer ou como, mas a intenção de ser útil deve ser considerada um pré-requisito para um conselho.

Embora isso pareça óbvio, pode fazer diferença em uma série de situações. Por exemplo, quando um conselho está "acomodado", participando de reuniões apenas para "cumprir tabela". Um conselho assim precisa estar atento a este princípio, pois muitas vezes cumpre seu papel "no automático", sem efetivamente estar tentando ser útil, buscando somente manter o status quo. Outro exemplo, é quando um conselheiro mantém-se no conselho porque foi convidado por um amigo ou porque não saberia o que fazer com aquele tempo ocioso - sutilmente, pode não estar predominando a intenção de ser útil àorganização e 
à sociedade. Por diversas razões, $d$ esde comodismo até insegurança, passando por dificuldades financeiras e conflitos de interesses, este princípio pode não estar sendo respeitado, levando a pessoa ou o grupo a colocar a si próprio em primeiro lugar e comprometendo qualquer perspectiva de desempenho do conselho.

O relacionamento do conselho com a organização a que faz parte (e as pessoas que a compõem) depende do interesse e da disposição em ser útil de cada conselheiro, e do grupo como um todo, nas mais diversas situações. Partindo deste princípio, o conselho torna-se apto a reconhecer que "este é o nosso problema", abrindo caminho para ser consultado, procurado, provocado e responsabilizado pelo que acontece na organização e fora dela.

\subsubsection{Princípio 2: Manter-se em contato com a realidade.}

Um conselho somente pode ser útil se conhecer a realidade em que atua. Realidade, neste caso, significa aquilo que ocorre na comunidade, na organização e no próprio conselho. Qualquer interação do conselho serve, a princípio, como fonte de informações sobre estas três instâncias e deve ser considerado como tal. Conhecer a realidade implica ser capaz de vivenciar o que acontece e de decifrar o que provoca os acontecimentos, distinguindo a natureza de cada situação.

Neste desafio de manter-se com o "pé no chão", o conselho precisa também estar aberto a reconhecer seus interesses, viéses, estereótipos, projeções e expectativas, que podem distorcer a percepção da realidade corrente. Todo conselheiro está sujeito a formar imagens cristalizadas e preconceitos, se não acompanha o que acontece no diaa-dia da organização e da comunidade. Juntos, os conselheiros (e as pessoas que eles eventualmente convidam) podem chegar a construir um quadro consistente da realidade e da melhor maneira de lidar com ela.

Muitos conselhos reúnem-se a cada 3, 4 ou 6 meses, com alguns membros vindo a tomar contato com suas organizações somente nestes momentos. Esse contato tão "pontual" pode prejudicar a formação de imagem a respeito da realidade, seja pela superficialidade, seja pelas distorções que podem haver. É importante que o conselho esteja atento ao seu processo de realizar "atividades diagnósticas", evitando confiar em imagens formadas a priori.

O processo de diagnóstico é tão importante quanto o diagnóstico em si. O simples fato dele não ser conduzido satisfatoriamente pode resultar em diferentes imagens da realidade ou à não aceitação de uma determinada conclusão. Nesse caso, é muito freqüente o conselho produzir "recomendações" e elas serem simplesmente ignoradas ou não colocadas em prática. É preciso muito exercício para aprender a identificar onde os problemas estão.

Algumas organizações regularmente enfrentam dificuldades financeiras, atribuindo-as à situação crítica do país ou àfalta de alguém para cuidar exclusivamente disso. Nem sempre a realidade é simplesmente essa; o conselho tem que continuar se perguntando porque a organização não está tendo recursos e o que isso pode ter a ver, por exemplo, com a efetiva realização do papel da organização na sociedade. Uma comunidade apoia uma organização da sociedade civil enquanto ela puder trazer benefícios para a sociedade, sugerindo que o conselho pode se perguntar, por exemplo, como está a imagem pública da instituição, como está a qualidade dos projetos que estão sendo enviados, como é o processo de captação de recursos, etc. 
Para conhecer a realidade o conselho precisa tomar cuidado ao prescindir do contato com parceiros, beneficiários, constituintes, funcionários e técnicos da entidade. Eventualmente, pelo simples fato do conselho ouvir a descrição da realidade percebida por estes grupos ele estará contribuindo para uma tomada de consciência e possível mudança de atitude em relação a alguns problemas.

\subsubsection{Princípio 3: Reconhecer e avaliar sua ignorância.}

A maioria das situações sociais em que trabalham as organizações é complexa e dinâmica, o que torna o seu dia-a-dia repleto de incertezas e variáveis. Nestas situações estão envolvidas normalmente um grande número de pessoas, que as percebem e reagem de maneiras diversas conforme seus valores, experiências e interesses. O conselho, pela posição que ocupa, pode procurar manter uma certa distância para obter uma visão de conjunto, mas deve estar consciente de que sempre trabalha sob um grau significativo de ignorância - não é possível saber de tudo o que acontece numa organização, numa comunidade ou mesmo entre os próprios conselheiros. Um conselheiro deve estar regularmente avaliando o quanto não sabe e estar se esforçando por aprender - sobre a comunidade, sobre a organização e sobre si próprio - para poder oferecer contribuições valiosas. Sob esta perspectiva, é importante que o conselheiro procure ouvir antes de falar, assegurando-se que realmente conseguiu avaliar aquilo que sabe e aquilo que não sabe.

Em várias situações, em função da sua ignorância o conselho poderá ser mais efetivo ao ajudar alguém a resolver um problema do que resolvê-lo sozinho. Muitos problemas permanecem resolvidos por mais tempo se as pessoas aprendem a resolvê-los, ao invés de ter alguém para resolver por elas.

Por causa disso, é importante que o conselho busque ativamente descobrir e solicite informações sobre seus erros - eles comumente refletem uma zona de ignorância ou desconhecimento. Boas intenções não justificam ações amadoras e inconseqüentes.

Como normamente os conselheiros já têm uma experiência significativa de vida e normalmente podem ser considerados bem sucedidos profissionalmente, costuma ser muito forte a tentação de dar opiniões e oferecer sugestões uma atrás da outra, mesmo quando não solicitadas. Isso pode distanciar o conselho não só da sua própria zona de ignorância, como também das pessoas com as quais interage, prejudicando o processo de governança como um todo. Isso pode ser verdade mesmo em casos em que a sugestão dada resolve o problema: pode acontecer simplesmente das outras pessoas não compreenderem a idéia simplesmente por viverem uma cultura diferente e utilizarem uma outra linguagem rotineiramente.

O oposto também pode acontecer, de alguns conselheiros sentirem-se intimidados e desmdivados justamente por sua ignorância e despreparo. Isto constitui uma realidade em si e o conselho precisa agir a partir dela, possivelmente promovendo sessões de orientação, treinamento e capacitação. Apenas ao reconhecer que o conselho é ignorante a respeito de uma série de temas e assuntos é que haverá uma disposição genuína em participar de processos de auto-avaliação e treinamento.

\subsubsection{Princípio 4: Reconhecer seus limites.}

Nenhum conselheiro individualmente pode resolver um problema institucional de fato. Nenhuma organização sozinha pode resolver um problema público realmente. Problemas importantes costumam ser complexos e insolúveis a curto prazo. Sua solução depende não só de boas idéias, mas do envolvimento de um conjunto de pessoas e instituições no seu enfrentamento. $O$ conselho precisa estar consciente que ele é 
somente parte da solução e que dele pode depender a participação efetiva, livre e integrada de outros no processo.

Isso é verdadeiro no âmbito do próprio conselho, no âmbito da organização e no âmbito da comunidade. Algumas vezes podese encontrar conselhos que são "dominados" ou "conduzidos" por uma só pessoa ou subgrupo. Pode ser uma ilusão querer manter isso por muito tempo, pelo tamanho dos desafios a serem enfrentados - nestas circunstâncias, pode-se verificar que muito do talento de alguns conselheiros não estão sendo aproveitados, pela mera falta de vontade em se envolver em algumas tarefas ou pela acomodação pouco criativa em "ser liderado". Se isso acontece no próprio conselho, que dirá na entidade toda e na comunidade...

Para explorar todo o potencial do conselho (da organização e da comunidade), é preciso provocar a emergência de diferenças de opinião, de discussões esclarecedoras e criativas, de questionamento das idéias que normalmente surgem - a diversidade é fonte de poder, na medida em que traz à tona perspectivas diferentes e possibilita às pessoas sentirem -se identificadas e responsáveis pelo problema em questão. Não existe vantagem em um conselheiro, grupo ou organização apropriar-se de um problema sozinha.

O reconhecimento deste tipo de contexto exige paciência e um profundo entendimento de processos de desenvolvimento, que têm que ser respeitados. Uma criança não se torna adulta sem passar pela adolescência; uma organização não se profissionaliza sem cometer erros; uma comunidade não se mobiliza enquanto estiver fragmentada e insegura. Mesmo internamente pode existir um processo de desenvolvimento em curso, que tem que ser respeitado.

Neste contexto, não dá para decidir sozinho, é preciso aprender a decidir em grupo.

\subsubsection{Princípio 5: Manter clareza sobre qual é o papel a ser exercido.}

A principal razão pela qual um conselho precisa definir seu papel é para poder exercê-lo plenamente. Isso depende não só do conselho como um todo; depende de cada um dos conselheiros, das demais instâncias organizacionais e dos demais agentes envolvidos no processo de governança e de desenvolvimento da comunidade.

Normalmente as pessoas, de dentro e/ou de fora da organização, esperam coisas do conselho, podendo expressar isso ou não. O conselho precisa ser capaz de reconhecer estas expectativas e posicionar-se a respeito delas, assumindo explicitamente aquilo pelo quê vai ser responsável e evitando criar malentendidos, desapontamentos e frustrações. Também pode ser útil o conselho afirmar pelo quê não se julga responsável, manifestando as expectativas que tem em relação aos outros grupos organizacionais e comunitários, desenvolvendo as bases para uma relação transparente e madura. Mesmo os conselheiros têm que conversar entre si sobre o que esperam uns dos outros e sobre como estas expectativas têm sido preenchidas.

O papel do conselho pode não ser o mesmo em todas as organizações. O conselho deve sentir-se responsável por avaliar as condições e o contexto em que está para definir conscientemente qual o melhor papel a ser exercido. Instituições passam por fases em seu desenvolvimento e têm necessidades distintas conforme amadurecem - o conselho pode decidir-se por assumir um papel mais apoiador ou consultivo, 
numa determinada etapa histórica da entidade; num outro período pode ser preciso ele assumir a dianteira das iniciativas institucionais, propondo e ajudando a realizar aquilo que precisa vir a acontecer.

Nenhum papel, entretanto, deve ser considerado eterno, porque as coisas naturalmente mudam com o passar do tempo. O ambiente muda, as pessoas mudam, as relações mudam e daí por diante; o papel do conselho precisa ser revisado em relação a estas mudanças, regularmente. "Qual é o papel a ser assumido neste contexto?", "O que deve mudar no papel que o conselho vem exercendo nos últimos 2 anos? Por quê?" deve se perguntar o conselho, bem como consultar outros a respeito. Com o passar do tempo, coisas que foram previamente definidas podem perder sua validade, exigindo que o conselho como um todo as revise.

Em algumas situações isto pode significar uma pergunta mais drástica, do tipo "O conselho é realmente necessário? Para quê?". O simples processo de auto-questionamento a respeito disso pode contribuir para renovar as relações dos conselheiros entre si, dos conselheiros com o conselho e do conselho com aqueles com quem interage.

O fato de alguns conselhos passarem a existir somente "no papel" pode refletir a falta de coragem, algumas vezes, de conversar sobre estas perguntas abertamente. Se um conselho passa a ser percebido como "velho", "antiquado" ou "não funciona" pode ser porque não ousa falar abertamente sobre seu papel na realidade atual.

Em outras situações, algumas lideranças executivas podem evitar levar os "problemas reais" para o conselho, mostrando a ele somente o que a organização tem de bom, em função de uma imagem não verdadeira do papel do conselho.

Estando bem claro o papel, as atribuições, as responsabilidades do conselho, fica mais fácil para ele decidir como deve trabalhar, definir metas para si próprio e planejar uma agenda com as suas principais atividades - tendo em mente que "contribuir com" é diferente de "assumir o compromisso de".

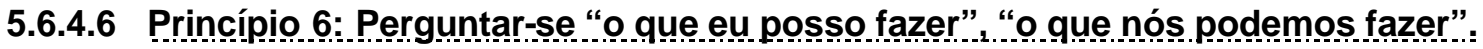

Tudo o que o conselho faz ou deixa de fazer é uma intervenção na realidade da organização e da comunidade. Tudo que o conselho faz ou deixa de fazer "cria cultura" na organização.

Se um conselheiro chega sempre atrasado nas reuniões, pode-se lentamente desenvolver uma tolerância institucional ao atraso, seja em reuniões, seja em qualquer outro tipo de evento. Se o conselho solicita regularmente comentários a respeito de suas decisões ou do seu trabalho, outras pessoas na entidade podem se sentir motivadas a fazer o mesmo. Neste aspecto, os detalhes importam e muito.

Pela posição que ocupa, o conselho é visível, mesmo a portas fechadas. Ele precisa estar muito atento e consciente da forma como se comporta, daquilo que faz e do que diz, pois ela costuma ter conseqüências.

Neste sentido, o conselho depende do esforço e da iniciativa de cada um dos seus membros. E o esforço de um só pode fazer diferença, mesmo que demore. Por exemplo, se numa reunião somente uma pessoa fala a maior parte do tempo e todos os outros ficam em silêncio, um que ousar reconhecer isso explicitamente e perguntar a todos por que isso acontece pode fazer uma grande diferença. 
Muitas situações insatisfatórias perduram porque a responsabilidade por elas é atribuída a "outros". Pressupostos do tipo: "o conselho não funciona porque eles já são muito de idade", "a organização vai mal porque eles não se dispõem a captar recursos", "ela (a comunidade) não muda porque ela não quer" contrariam o princípio proposto. Questionamentos do tipo "O que é possível fazer diferente nesta situação que sempre se repete?", "O que nós temos a ver com isso?" ou "Como o conselho contribui para que as coisas estejam como estão?" refletem a aplicação prática deste princípio. Ele exige que o cons elho esteja ativo, ou melhor, proativo. O conselho todo deve se perguntar "o que nós podemos fazer", conduzindo a organização (e quem sabe a comunidade) a fazer o mesmo.

Não é incomum em algumas entidades haver frustrações e preconceitos quanto à utilidade do conselho porque os conselheiros ficam somente dando palpites e sugestões sem realmente disporem-se a fazer algo diferente. Em muitas situações a equipe executiva, a equipe técnica ou outros colaboradores podem simplesmente não se sentirem capazes de fazer o que o conselho propõe. O conselho deve participar da ação sempre que necessário, dando o exemplo - isso implica estar e manter-se disponível.

\subsubsection{Princípio 7: Ajudar o outro a cumprir seu papel.}

Pela natureza das atividades do terceiro setor, predomina a boa vontade, mas nem sempre as pessoas estão bem preparadas para cumprir o seu papel, inclusive no próprio conselho. Para isso elas podem precisar de ajuda.

O conselho será capaz de ajudar outros quando estiver ele próprio fazendo isso internamente: os conselheiros devem se ajudar mutuamente a cumprir seu papel. Cada conselheiro deve estar atento aos seus pares, estando disponível para ajudá-los quando necessário. Esta ajuda pode significar, na maioria das vezes, a transferência de algumas informações ou habilidades para o trabalho, evitando criar dependência. Como instância colegiada, o conselho precisa aprender a trabalhar em conjunto e no mesmo nível.

Os conselheiros são as pessoas em melhores condições para ajudar seus pares a cumprir seu papel - eles têm legitimidade e autoridade para isso. Assim, um conselheiro deve estar preparado para dar e receber comentários dos seus colegas a respeito do seu trabalho.

Este princípio se aplica também em relação àqueles que não são do conselho: diretoria, liderança executiva, equipe técnica, parceiros, etc. Ajudar os outros a cumprir seu papel pode significar desde não interferir em suas tarefas até evitar que outros o façam. Pode ser simplesmente solicitar esclarecimentos e definições melhores sobre o que elas se vêem realizando. E pode ser convidar a participar de reuniões, seminários, treinamentos, etc.

Ao contribuir, por exemplo, para que um planejamento seja bem feito, o conselho poderá estar colocando este princípio em prática, na medida em que metas bem definidas facilitam a execução de tarefas. Ao facilitar o diálogo entre parceiros num determinado projeto, o conselho atua para que um compreenda as idéias do outro e aproveite as suas capacidades.

Várias foram citações de casos em que os conselheiros envolveram-se em tarefas específicas nas suas organizações colocando seu talento e experiência técnica à disposição - num deles um conselheiro 
contribuiu para atualização técnica de um contador, por exemplo, dando uma boa indicação de como este princípio pode ser colocado em prática.

Ajudar o outro a cumprir seu papel pode ser bem diferente de dizer o que ele tem que fazer: é torná-lo mais capaz de realizar conscientemente aquilo que ele se propõe a fazer. Por exemplo, num caso citado anteriormente um conselho aceitou a permanência de uma pessoa na coordenação de algumas atividades porque o administrador da entidade assim o queria, embora o conselho discordasse - o conselho fez isso para que ele pudesse sentir-se seguro sobre sua autonomia e tivesse a oportunidade de errar para aprender.

O foco deste princípio é, portanto, o outro - conselheiro, equipe executiva, parceiro, cliente, etc. O conselho precisa ser capaz de estabelecer um relacionamento em que a comunicação é possível e que o permita ajudar os outros, bem como ser ajudado.

Um bom conselho pode receber muitos pedidos de ajuda, o que o coloca numa posição de bastante poder. Será preciso muita sabedoria e disciplina para saber distinguir o que está realmente acontecendo em cada caso e como efetivamente pode ser útil, ao invés de simplesmente "dar a resposta" àquela situação, criando dependência. $O$ conselho deve ser visto como mais um parceiro na solução dos problemas e na mudança social e não como "o" responsável por ela.

Para ajudar os outros a cumprir o seu papel, o conselho também precisa entender que isso depende do aumento da capacidade de aprender, de modo que se possa resolver futuros problemas e lidar com novas situações. O conselho precisa estar preparado, por conseguinte, para não assumir o papel dos outros.

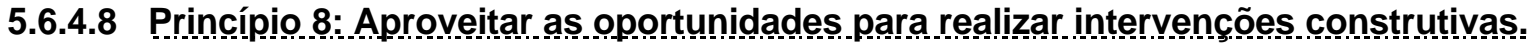

A maioria dos problemas sociais e organizacionais envolvem interações humanas e processos. Sempre há gente envolvida. Para que mudanças efetivamente aconteçam nestas interações humanas é preciso aproveitar as oportunidades de abertura que acontecem. Existem momentos em que de fato o conselho está numa posição de liderança e a atenção de um ou mais atores está disponível - estes momentos podem ser cruciais em processos de desenvolvimento pessoal, organizacional e comunitário. No limiar do século XXI, as pessoas não fazem as coisas porque alguém está dizendo para elas fazerem, mas porque estão convencidas de que são importantes de serem feitas.

O caso da Entidade 8, descrito anteriormente neste documento, apresenta uma dessas oportunidades, quando o conselho aproveita os 10 anos de existência da entidade e pergunta: "comemora ou não comemora?". Quando a presidente da entidade 10 afirma "ESTOU TÃO SOZINHA ... ULTIMAMENTE ESTÁ DIFÍCIL", ela pode estar indicando um momento de abertura, em que a contribuição de outros ao seu redor pode ajudá-la a trabalhar as coisas de uma maneira diferente.

Uma vez que os relacionamentos do conselho com os diversos atores envolvidos no processo de governança institucional estiver baseado na confiança e no respeito mútuo, o conselho precisa estar atento a momentos de abertura e agir sobre eles de maneira construtiva, aproveitando os pontos fortes do outro e construindo sobre motivações positivas.

Um erro ou um insucesso num projeto ou evento podem representar oportunidades deste tipo e o conselho, se esteve próximo, ativo e numa posição de confiança pode ter um papel tanto de aprendiz como de mestre, 
criando condições para que cada envolvido possa desenvolver novos princípios de ação para circunstâncias futuras. O conselho precisa estar atento, disponível e preparado para aproveitar os momentos em que há de fato abertura para que algo na dinâmica social mude. Nem tudo depende das decisões do conselho, especialmente em processos de desenvolvimento.

Em todas as organizações e comunidades costumam existir temas ou questões com as quais tem -se que conviver, devido: ao seu estágio natural de amadurecimento, a problemas políticos, a processos históricos e outros motivos. Pode ser um equívoco tentar forçar, por pressão ou argumentos, uma evolução ou mudança - isso muitas vezes tende a gerar maior resistência do que crescimento. Assim, é preciso que o conselho esteja atento à oportunidades que surgem para ef etuar intervenções construtivas. O "timing" é importante e pode fazer diferença. No próprio conselho, na interação entre os conselheiros, isso pode ser válido.

A adoção deste princípio também significa assumir que pensamentos do tipo "ganhar ou perder" poucas vezes levam a resultados satisfatórios e que é preciso procurar soluções aceitáveis para todos os envolvidos, especialmente numa crise.

\subsubsection{Princípio 9: Fazer escolhas conscientemente.}

A capacidade física de trabalho do conselho é muito pequena e a demanda pode ser muito grande, exigindo que ele se concentre no que é essencial, no que é importante e no que ainda pode ser feito (no futuro). Isto implica em fazer escolhas, que trarão conseqüências para uma série de pessoas e mesmo para a sociedade como um todo.

Às vezes o conselho se concentra em assuntos secundários ou urgentes porque pressupõe que não é possível fazer escolhas ou que não há escolhas a serem feitas. Ou ainda, porque há risco em determinadas escolhas, exigindo que o conselho se comprometa com elas.

Fazer uma escolha não pode ser uma atividade comum, que se realiza de um momento para outro - fazer escolhas tem que ser encarado pelo conselho como um processo. A escolha será tanto melhor, quanto melhor conduzido for o processo de escolha.

No diaz-dia institucional o conselho faz e participa de uma série de escolhas: sobre o horário e a freqüência das suas reuniões, sobre sua agenda de trabalho durante o ano, sobre quanto tempo um conselheiro deve permanecer na entidade, sobre a missão da organização, sobre um programa a ser desenvolvido, sobre um conjunto de parcerias, sobre a alocação de investimentos e daí por diante. Quais são as escolhas importantes? Qual o impacto que uma escolha feita pelo conselho deve ter? Qual foi o impacto de uma escolha feita no passado? Como têm sido conduzidos os processos de escolha do conselho? As grandes escolhas são feitas individualmente ou em grupo? O que é importante de fato para a comunidade? E para a organização?

Quando o conselho estiver em dúvida sobre uma determinada escolha a ser feita, pode compartilhar esta dúvida e pedir ajuda, consultar outras pessoas de dentro e de fora da organização. Deve evitar fazer uma escolha simplesmente porque uma escolha tem que ser feita. Se uma escolha tem mesmo que ser feita, pode-se definir, então, até quando ela é válida. 
A Entidade 6 fez uma escolha de abandonar um serviço prestado desde a fundação da entidade, em função do caso de um aluno que chegou à justiça. A Entidade 5 fez uma escolha ao contratar um administrador profissional para trabalhar com a irmã missionária.

Escolhas sempre envolvem critérios. É sempre com base em critérios, implícitos ou explícitos, que se faz uma escolha. Ao tomar consciência de quais critérios foram válidos numa situação o conselho pode estar dando um grande passo para tornar consciente o seu processo de escolha. Por exemplo, quais foram os critérios utilizados pelas duas entidades citadas acima?

Evidentemente, o conselho poderá ser mais efetivo ao se concentrar em questões importantes, tanto para a organização quanto para a sociedade. Porém, isso implica que uma escolha sobre o que é importante já tenha sido feita.

Pode ser útil lançar mão de parâmetros nos processos de escolha que envolvem o conselho; parâmetros como os elementos essenciais da identidade institucional (missão, visão, valores, objetivos, estratégias, etc.), indicadores sociais ou o parecer de consultores externos podem ser de utilidade em muitos casos.

O desenvolvimento de habilidades de síntese e questionamento também pode ajudar. Por exemplo, a habilidade de fazer perguntas para as quais não se tem respostas pode enriquecer e tornar o processo de escolha mais consciente.

Alguns autores pesquisados sugerem que o conselho pode colocar-se no lugar de diferentes audiências institucionais e perguntar-se: "O que é importante para elas? E para os parceiros? E para entidades similares?" - também enriquecendo o processo de escolhas.

\subsubsection{Princípio 10: Prestar contas do trabalno}

Participar de um conselho de uma OSC é assumir uma responsabilidade e um compromisso formal perante outros, primeiro pelo desenvolvimento de algum aspecto da sociedade e depois pelo desenvolvimento de uma organização. De certa forma, o conselho representa a sociedade no governo de uma entidade social, por isso que é composto por voluntários. Assim, ao redor de toda e qualquer entidade social existe uma comunidade, bem ou mal definida, que a sustenta, seja pela contratação de serviços, seja através de doações, para que possa exercer seu papel social.

O conselho é parte, portanto, de uma comunidade maior à qual deve prestar contas. Prestar contas não é meramente colocar o balanço no jornal. É dispor-se a ouvir o que ela tem a dizer sobre o seu trabalho. É refletir sobre quais são os resultados alcançados junto com representantes da comunidade. Prestar contas é dar segurança àcomunidade de que aquela organização está operando de uma maneira responsável.

As reuniões do conselho consultivo podem ser consideradas uma forma de prestação de contas à comunidade da Entidade 3, composta primariamente por ex-alunas de um determinado colégio. Exposições, por exemplo, de trabalhos realizados por alunos de uma creche ou centro educacional também podem ser formas de prestar contas à sociedade, desde que haja oportunidades do conselho interagir com essa comunidade. Informar e consultar parceiros atuais e potenciais a respeito da avaliação do trabalho da entidade e dos planos para o futuro também pode ser considerada uma forma de prestação de contas. 
Cada organização da sociedade civil para cumprir sua missão depende do apoio e do esforço da comunidade ao seu redor - o conselho deve assegurar-se de nutrir o vínculo com esta comunidade, prestando contas a ela e solicitando sugestões sobre seu trabalho. A forma pela qual um conselho presta contas revela sobre o respeito que o conselho tem pela comunidade que representa e sobre a visão do seu relacionamento com ela.

\subsubsection{QUANTO AO PAPEL DO CONSELHO - UMA HIPÓTESE}

Os seguintes dados são intrigantes:

$\Rightarrow$ Em 7 das organizações estudadas foi detectada a presença dos fundadores, estando estes em posição de liderança em pelo menos 6 destes casos;

$\Rightarrow$ Em duas das 10 entidades não existe diretoria, somente conselho; em 7 coexistem formalmente conselho e diretoria;

$\Rightarrow$ Nas entidades em que coexistem conselho e diretoria: (a) em 3 casos o conselho existe praticamente "no papel", sendo o governo da instituição liderado pela diretoria; (b) em 3 casos o conselho e a diretoria estão diferenciados na prática, mas a liderança estratégica e carregadora reside na diretoria; (c) em 1 caso a liderança é compartilhada.

$\Rightarrow$ De maneira geral e em níveis diferentes: (a) 6 das 10 entidades podem ser consideradas numa fase pioneira de desenvolvimento; (b) 1 entidade está numa fase de transição da fase pioneira para a diferenciada; (c) 2 entidades podem ser consideradas na fase diferenciada.

$\Rightarrow \quad$ Em duas entidades coexistem conselho, diretoria e superintendência ativos.

Um indicativo importante da pesquisa é que não se justifica, em algumas entidades estudadas, a existência de um conselho e uma diretoria. Esta afirmativa leva em consideração o papel funcional e o papel legal do conselho. A existência destes dois órgãos só se justifica em organizações maiores e amadurecidas, com um grau mais alto de complexidade de gestão. Em organizações que estão numa fase "pioneira", com presença predominante dos fundadores, a existência dos dois órgãos representa uma sobrecarga para a liderança executiva, levando um deles a ser colocado em segundo plano. Aparentemente, é suficiente a definição de um comitê executivo, dentro do conselho (ou diretoria), para acompanhar as atividades do dia-a-dia. Os argumentos que sustentam esta idéia são apresentados a seguir.

A pesquisa realizada mostrou que pode haver (e normalmente há) diferenças entre o papel do conselho de uma organização da sociedade civil definido no estatuto e o papel exercido na prática. Não é possível fazer uma generalização sobre qual deve ser o papel do conselho em todas as organizações; é possível, porém, afirmar que cada organização deve estabelecer muito bem qual é o conselho que quer ter e porquê.

Assim, um órgão denominado "conselho" pode ter exatamente as mesmas atribuições de um órgão denominado "diretoria", em dois contextos organizacionais diferentes. Os termos "conselho" e "diretoria" são tratados, como foi visto, como sinônimos por várias lideranças e mesmo por dicionários, sendo importante que cada organização desenvolva clareza sobre o seu significado e não significado. A mera denominação de um grupo como "conselho" ou "diretoria" é, na práti ca, insuficiente para explicar o seu sentido, sendo uma fonte potencial de desapontamentos e frustrações. 
É possível generalizar, entretanto, sobre um papel de conselho e um papel de diretoria, considerando a existência de 3 grandes subsistemas organizacionais proposto por Large, Lievegoed e outros autores:

- Subsistema técnico: compreende todas os métodos, procedimentos e técnicas que fundamentam os produtos e serviços prestados pela organização, estando vinculado à produção de resultados específicos, exigindo um preparo profissional para sua implementação - o subsistema técnico está voltado primariamente à realização dos objetivos e metas institucionais; geralmente estas atividades estão atribuídas a educadores, médicos, psicólogos, cozinheiras, professoras, assistentes sociais, consultores, etc.

- Subsistema social: compreende as relações entre os diversos membros e instâncias da organização e à integração entre eles, através de acordos e normas - o subsistema social está voltado à organização e coordenação institucional; geralmente suas atividades são atribuídas a coordenadores, monitores, facilitadores, gerentes, superintendentes, consultores internos, supervisores, diretores, etc.

- Subsistema econômico: neste subsistema estão os objetivos e propósitos da ins tituição, definidos para assegurar que a organização desempenhe um papel relevante na sociedade e atenda ìs necessidades de um ou mais grupos determinados; sobre ele normalmente concentram -se fundadores, sócios, carregadores, presidentes, diretores, conselheiros, curadores, etc.

A hipótese que este estudo levanta é que a liderança pelo desenvolvimento do subsistema econômico pode ser atribuída conceitualmente ao conselho, ou seja, exercer um papel de conselho é exercer um papel de liderança do subsistema econômico numa organização. E a liderança pelo desenvolvimento do subsistema social pode, por conseguinte, ser atribuída à diretoria, ou seja, exercer um papel de diretoria é exercer um papel de liderança do subsistema social da entidade. Esta distinção é importante para ajudar a desmistificar um conceito genérico de conselho e para que se possa identificar quem exerce, na prática, o papel de conselho numa organização da sociedade civil.

Evidentemente, as lideranças dos diferentes subsistemas, na realidade, podem não estar diferenciadas, conforme indicou o estudo da bibliografia especializada e das organizações da Rede Nossas Crianças. $\mathrm{Na}$ fase pioneira, por exemplo, um mesmo grupo pode exercer a liderança dos três subsistemas, exercendo, ele o papel de conselho. Como se viu, o processo de diferenciação está vinculado ao processo de desenvolvimento organizacional, que apesar de obedecer a padrões gerais comuns, acontece de maneira específica para cada organização.

Apresentados esquematicamente, os três subsistemas poderiam ser representados da seguinte maneira: 


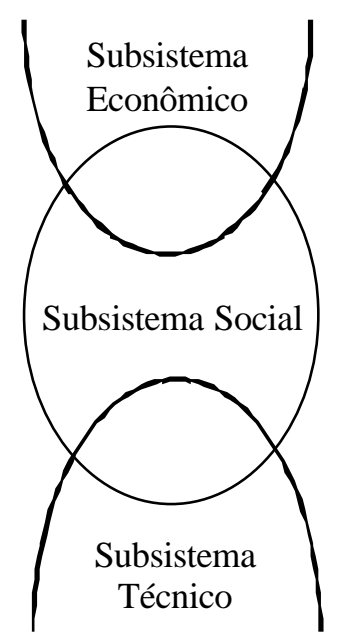

Se substitui-se a representação dos subsistemas pela representação dos seus órgãos de liderança plenamente diferenciados, o esquema pode ficar assim:

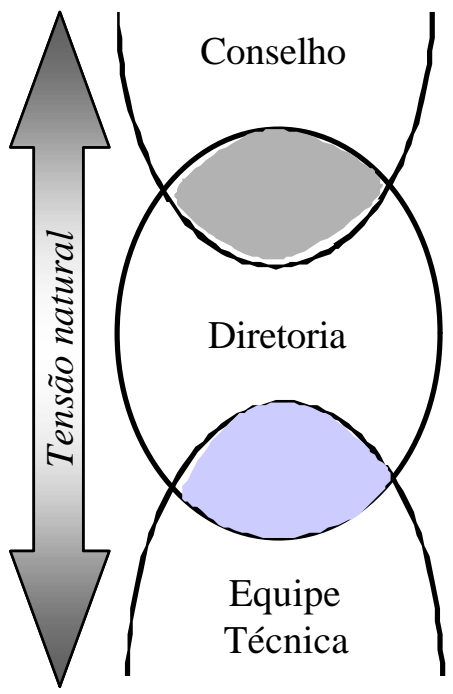

As "zonas cinzentas" parecem ser preenchidas na prática por instâncias como comitê executivo, superintendência, gerência, coordenação, entre outras.

Estas descrições e esquemas deixam implícitas algumas das tensões identificadas anteriormente, de maneira simbólica, sugerindo que:

(a) qualquer análise do sistema de governança institucional deve ser feita em duas direções: de dentro para fora e de fora para dentro da organização e suas diferentes instâncias;

(b) sob esta perspectiva, a existência deste tipo de tensão pode ocasionar, por exemplo, o surgimento de comissões ou comitês.

Nos casos analisados, pôde-se perceber que a diferenciação entre o grupo que tem papel de conselho e o grupo que tem papel de diretoria ainda é incipiente, para a maioria das organizações. Na prática estes dois papéis estão concentrados nas principais lideranças institucionais. Por se tratarem de processos de desenvolvimento, é preciso ter cautela ao se "forçar" qualquer diferenciação, pois nenhuma das partes envolvidas pode estar preparada para ela. Para que esta diferenciação ocorra com o mínimo de frustração 
possível poderá ser preciso lançar mão de conceitos e técnicas do conhecido D.O. (desenvolvimento organizacional).

Isto significa, concretamente, que algumas entidades não necessitariam ter, por enquanto, um conselho e uma diretoria.

Ainda, todo o estudo realizado sugere uma outra dimensão dos grupos, expressa no desenho abaixo:

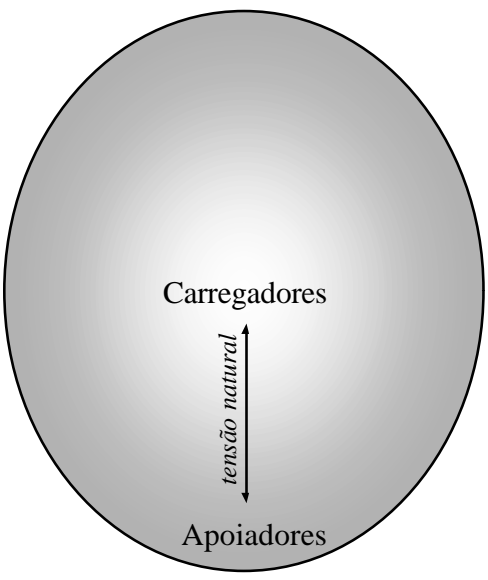

Considerando que em um grupo de iniciativa pode-se encontrar carregadores e apoiadores, é de se pressupor que nas instâncias que estamos denominando "conselho" e "diretoria" exista, em maior ou menor grau, uma tensão natural entre carregadores e apoiadores. A existência desta tensão pode determinar a existência de sub-grupos, como por exemplo um conselho consultivo.

\begin{tabular}{|c|c|c|c|c|c|c|}
\hline Subsistema & Abrangência & Produtos & Finalidade & $\begin{array}{c}\text { Papéis } \\
\text { principais }\end{array}$ & $\begin{array}{l}\text { Tipo de } \\
\text { liderança }\end{array}$ & $\begin{array}{c}\text { Órgãos } \\
\text { associados }\end{array}$ \\
\hline Econômico & $\begin{array}{l}\text { Identidade } \\
\text { organizacional }\end{array}$ & $\begin{array}{l}\text { Missão, visão, } \\
\text { diretrizes, } \\
\text { metas, objetivos }\end{array}$ & $\begin{array}{l}\text { Assegurar o } \\
\text { impacto social } \\
\text { desejado, } \\
\text { atender } \\
\text { necessidades do } \\
\text { público-alvo }\end{array}$ & $\begin{array}{l}\text { Fundador, sócio, } \\
\text { carregador, } \\
\text { presidente, } \\
\text { diretor, } \\
\text { conselheiro, } \\
\text { curador, etc. }\end{array}$ & Constitucional & $\begin{array}{l}\text { Conselho, } \\
\text { Diretoria }\end{array}$ \\
\hline Social & $\begin{array}{l}\text { Relações entre } \\
\text { pessoas, grupos } \\
\text { e departamentos }\end{array}$ & $\begin{array}{l}\text { Regras e } \\
\text { acordos formais } \\
\text { e informais de } \\
\text { trabalho }\end{array}$ & $\begin{array}{l}\text { Manter a coesão } \\
\text { da equipe e a } \\
\text { integração dos } \\
\text { esforços }\end{array}$ & $\begin{array}{l}\text { Coordenador, } \\
\text { monitor, } \\
\text { facilitador, } \\
\text { gerente, } \\
\text { superintendente, } \\
\text { consultor } \\
\text { interno, } \\
\text { supervisor, } \\
\text { diretor, etc. }\end{array}$ & Organizacional & $\begin{array}{l}\text { Diretoria, } \\
\text { Superintendênci } \\
\text { a, Administração }\end{array}$ \\
\hline Técnico & $\begin{array}{l}\text { Métodos, } \\
\text { procedimentos, } \\
\text { técnicas, } \\
\text { habilidades e } \\
\text { tarefas } \\
\text { específicas }\end{array}$ & $\begin{array}{l}\text { Tipos diferentes } \\
\text { de serviços, } \\
\text { formas } \\
\text { diferentes de } \\
\text { trabalhar }\end{array}$ & $\begin{array}{l}\text { Produzir } \\
\text { resultados } \\
\text { específicos e } \\
\text { determinados }\end{array}$ & $\begin{array}{l}\text { Educador, } \\
\text { médico, } \\
\text { psicólogo, } \\
\text { cozinheira, } \\
\text { professora, } \\
\text { assistente } \\
\text { social, consultor, } \\
\text { etc. }\end{array}$ & Técnica & $\begin{array}{l}\text { Equipe técnica, } \\
\text { equipe executiva }\end{array}$ \\
\hline
\end{tabular}




\subsection{LIMITAÇÕES IMPORTANTES}

A pesquisa proposta tem, reconhecidamente uma série de limitações, entre as quais:

- As informações sobre os conselhos das organizações da sociedade civil foram obtidas de apenas duas fontes: o representante do conselho e a liderança executiva. Esta situação dá um caráter bastante subjetivo à pesquisa, por alguns motivos: nem sempre as pessoas têm formação no campo da administração, nem tampouco são lideranças legítimas dos conselhos, nem ainda têm uma visão imparcial, abrangente ou representativa do trabalho de seus grupos.

- O conhecimento da realidade das organizações estudadas foi obtido somente através de um pequeno número de entrevistas, de uma análise dos estatutos disponíveis no momento e dos materiais de divulgação institucional - todos os julgamentos podem contém um grau significativo de imprecisões, exigindo outras pesquisas para sua confirmação.

- O tempo de entrevista (60 a 90 minutos) foi demasiadamente subestimado, sob a premissa de que os entrevistados são pessoas extremamente ocupadas e podiam despender somente este tempo com o pesquisador - isso redundou, em alguns casos, em extrema superficialidade na coleta de informações que pode afetar a validade de algumas interpretações.

- O presente estudo reflete as limitações próprias do Programa Nossas Crianças, pois não tem como objetivos analisar em profundidade o desempenho das organizações, assumindo que o Programa fornece um referencial parcial para isso.

- Não são possíveis generalizações, tanto pelo reduzido conhecimento da população, como pelos procedimentos de amostragem propostos. Assim, œ resultados não necessariamente representam qualquer população.

- O desempenho de uma organização é resultado de um sem número de fatores e variáveis que fica praticamente impossível afirmar qualquer coisa a respeito da eficácia do conselho sem incorrer em imprecisões e equívocos.

- Muito dos julgamentos realizados podem ter sido influenciados pela experiência limitada do pesquisador em trabalhos de desenvolvimento organizacional com alguns conselhos e diretorias organizações da sociedade civil. 


\section{Referências bibliográficas}

1. ADIZES, I. "Os ciclos de vida das organizações: como e por que as empresas crescem e morrem e o que fazer a respeito". São Paulo: Pioneira, 1993.

2. ANDERSSON, G. "The governance of changing organisations - first draft". Mimeografado. Johannesburg: Development Resources Centre, 1999.

3. ANDERSSON, G. "The governance of changing organisations - final draft". Mimeografado. Washington D.C.: National Center for Nonprofit Boards, 1999.

4. CARVER, J. "Boards that make a difference: a new design for leadership in nonprofit and public organizations". 2nd ed. San Francisco: Jossey- Bass, 1997.

5. CHAIT, R.P. "Como ajudar seu conselho diretor a governar mais e administrar menos". Washington D.C.: National Center for Nonprofit Boards, 1996.

6. CHAIT, R., HOLLAND, T.P. \& TAYLOR, B.E., "The Effective Board of Trustees". American Council on Education and The Oryx Press, Arizona, EUA, 1993.

7. CHAIT, R., HOLLAND, T.P. \& TAYLOR, B.E., "Improving the performance of governing boards". The Oryx Press, Arizona, EUA, 1996.

8. COELHO, S. C. T.. "Terceiro Setor: um estudo comparativo entre Brasil e Estados Unidos". São Paulo: Editora SENAC São Paulo, 2000.

9. DRUCKER, P.F. "Administração de organizações sem fins lucrativos: princípios e práticas". São Paulo: Pioneira, 1994.

10. DRUCKER, P.F. "Introdução àadministração". São Paulo: Pioneira, 1984.

11. FALCONER, A.P. "A Promessa do Terceiro Setor: um estudo sobre a construção do papel das organizações sem fins lucrativos e do seu campo de gestão". Dissertação de Mestrado, FEA-USP, São Paulo: 1999.

12. FALCONER, A. Repensando o Público na América Latina: As Organizações da Sociedade Civil. International Society for Third Sector Research - ISTR, Primeiro Encontro da Rede de Pesquisa do Terceiro Setor da América Latina e Caribe. RITS, www.rits.org.br, 1999.

13. FERNANDES, R.C. "Privado porém público: o terceiro setor na América Latina". Rio de Janeiro: Relume-Dumará, 1994.

14. FERRAREZZI, E. "OSCIP - Organização da sociedade civil de interesse público: a lei 9.790/99 como alternativa para o terceiro setor". Brasília: Comunidade Solidária, 2000.

15. FLANAGAN, J. (1954). The critical incident Technique. Psichological Bulletin, 51(4), 327-358.

16. GIES, D.L., OTT, J.S. \& SHAFRITZ, J.M. "The nonprofit organization: essential readings". Belmont: Wadsworth Publishing Company, 1990. 
17. GLASL, F. "The enterprise of the future: moral intuition in leadership and organisation development". Inglaterra: Hawthorn Press, 1997.

18. GOYOS JÚNIOR, D.N. “Noronha's Legal Dictionary: English-Portuguese”. 1a, ed. São Paulo: Observador Legal Editora Ltda., 1992.

19. HAETINGER, H. "Leis e fases na evolução das organizações”. Mimeografado. São Paulo, 1997.

20. HALL, P.D. "A History of Nonprofit Boards in the United States". Washington: National Center for Nonprofit Boards, 1997.

21. "Harvard Business Review on Nonprofits". EUA: Harvard Business School Press, 1999.

22. HOLLAND, T.P. \& BLACKMON, M. "Measuring board effectiveness: a tool for strengthening your board". EUA: National Center for Nonprofit Boards, 2000.

23. HOLLAND, T.P., RITVO, R.A. \& KOVNER, A.R. "Improving board effectiveness: practical lessons for nonprofit health care organizations”. Chicago: American Hospital Publishing, 1997.

24. HOLLAND, T.P., CHAIT, R.P. \& TAYLOR, B.E., "Board Effectiveness: Identifying and Measuring Trustee Competencies". Research in Higher Education, vol. 30, no. 4, p. 435-453, 1989.

25. HOLLAND, T.P. \& HESTER, D.C. "Building effective boards for effective religious organizations: a handbook for trustees, presidents and church leaders”. San Francisco: Jossey-Bass, 2000.

26. HORNBY, A.S. "Oxford Advanced Learner's Dictionary of Current English". Oxford: Oxford University Press, 1995.

27. HOULE, C.O. "Governing Boards: their nature and nurture". San Francisco: Jossey Bass, 1997.

28. HUDSON, M. "Administrando organizações do terceiro setor". São Paulo: Makron Books, 1999.

29. INGRAM, R.T., "Ten Basic Responsibilities of Nonprofit Boards". National Center for Nonprofit Boards, Washington, DC, EUA, 1997.

30. KANITZ, S. \& LORENZI, L., "Entidades Vencedoras - Prêmio "Bem Eficiente" de 1998". São Paulo, março de 1998.

31. KAPLAN, A. "The development practitioners' handbook". Chicago: Pluto Press, 1996.

32. KNAUFT, E.B., BERGER, R.A. \& GRAY, S.T. Profiles of excellence: achieving success in the nonprofit sector. Jossey Bass Inc. Publishers, San Francisco, EUA: 1991.

33. LAKEY, B.M. "Nonprofit governance: steering your organization with authority and accountability". Washington D.C.: National Center for Nonprofit Boards, 2000.

34. LANDIM, L. "Ações em sociedade: militância, caridade, assistência, etc." Rio de Janeiro: NAU, 1998.

35. LANDIM, L. e VILHENA, L.R., "O Terceiro Setor no Brasil", mimeografado, julho de 1998.

36. LARGE, M. "Social Ecology: exploring post industrial society". Gloucester (Inglaterra): Martin Large, 1981. 
37. LIEVEGOED, B.C.J. "Managing the developing organization: tapping the spirit of Europe". Cambridge: Basil Blackwell, 1991.

38. LODI, J.B. Conselho de Administração. São Paulo: Pioneira, 1988.

39. LODI, J.B. "Governança corporativa: o governo da empresa e o conselho de administração". Rio de Janeiro: Campus, 2000.

40. LOVISOLO, E., PEREIRA, B.H.A. \& POZZOLI, T.C. "Larousse Cultural: Dicionário da Língua Portuguesa". São Paulo: Nova Cultural, 1992.

41. MARINO, E., "Terceiro Setor: O Desafio da Conceitualização", mimeografado, 1999.

42. MARTINS, P. H. "Qual a diferença entre organizações sociais e organizações da sociedade civil de interesse público?" In: www.rits.org.br

43. MATHIASEN III, K. "A evolução dos conselhos: três estágios importantes na vida do conselho diretor de uma organização sem fins lucrativos". Tradução de Eduardo Marino. Washington, D.C.: National Center for Nonprofit Boards, 1996.

44. MATTAR, F.N., "Pesquisa de Marketing", volumes 1 e 2. Editora Atlas, São Paulo, 1997.

45. MONACO, D.C. "Estudo da composição dos conselhos de administração e instrumentos de controle das sociedades por ações no Brasil”. Dissertação de Mestrado. São Paulo: FEA/USP, 2000.

46. NOVAES, R.R. Juventude e ação social católica no rio de Janeiro: resultados de pesquisa. In: LANDIM, L. Ações em sociedade: militância, caridade, assistência, etc. Rio de Janeiro: NAU, 1998.

47. OLAK, P.A. "Eficácia na aplicação do Contrato de Gestão nas Organizações Sociais Brasileiras". Tese de Doutorado em Ciências Contábeis. São Paulo: FEA/USP, 2000.

48. OLIVER, C., CONDUFF, M., EDSALL, S., GABANNA, C., LOUCKS, R., PASZKIEWICZ, D., RASO, C. \& STIER, L. "The policy governance fieldbook: pratical lessons, tips and tools from the experience of real-world boards". San Francisco: Jossey-Bass, 1999.

49. ORLIKOFF, J.E. "Practices of super boards". Assocation Management, p. 52 -58, Janeiro 1998.

50. PAES, J.E.S. "Fundações e entidades de interesse social - aspectos jurídicos, administrativos, contábeis e tributários". Brasília: Brasília Jurídica, 1999.

51. SALAMON, L.M.. America's Nonprofit Sector: a primer. Nova York: The foundation Center, 1992.

52. SALAMON, L.M. \& ANHEIER, H.K. Defining the Nonprofit Sector - A cross-national analysis. Johns Hopkins Nonprofit Sector Series, Manchester University Press, New York: 1997.

53. SANTOS, H.M. "Conselhos de administração: um estudo do funcionamento da governança corpo rativa". Dissertação de Mestrado. São Paulo: FEA/USP, 2000.

54. SCHAEFER, C. \& VOORS, T. "Desenvolvimento de Iniciativas Sociais: da visão inspiradora à ação transformadora". São Paulo: Antroposófica, 2000.

55. SCHEIN, E.H. "Process consultation revisited: building the helping relationship". EUA: Addison-Wesley, 1999. 
56. SILVA, A.L.P. “Utilizando o planejamento como ferramenta de aprendizagem”. São Paulo: Global, 2000.

57. TANDON, R. \& GEORGE, V. "Governance of Voluntary Development Organizations". India: Institutional Development Journal, vol. VI nr. I, 1999.

58. TAYLOR, B.E., CHAIT R.P. \& HOLLAND, T.P., "The New Work of the Nonprofit Board". Harvard Business Review, September-October 1996.

59. TOLEDO, P.F.C.S. "O conselho de administração na sociedade anônima: estrutura, funções e poderes, responsabilidade dos administradores”. 2a ed. São Paulo: Atlas, 1999.

60. VERA, E. "Speech before the USAID Advisory Committee on Voluntary Foreign Aid". Mimeografado. EUA: Março, 1998.

61. VIEIRA NETO, M.A. (org.) Código Civil Brasileiro. São Paulo: Saraiva, 1984.

62. WIDMER, C.H. \& HOUCHIN, S. "The art of trusteeship: the nonprofit board member's guide to effective governance". San Francisco: Jossey-Bass, 2000. 


\section{AnEXos}

\subsection{TABELAS}

\begin{tabular}{|c|c|c|}
\hline \multicolumn{3}{|c|}{ Pesquisa Estatutária - Rede Nossas Crianças } \\
\hline Base $=2000$ & Total & $\%$ \\
\hline Nr. Entidades & 66 & $100 \%$ \\
\hline Conveniadas (FADC) & 42 & $64 \%$ \\
\hline Idade média (anos) & 29 & \\
\hline Idade estatutos (anos) & 9 & \\
\hline \multicolumn{3}{|l|}{ Atividades } \\
\hline Profissionalizantes & 26 & $39 \%$ \\
\hline Creches & 39 & $59 \%$ \\
\hline Centro Ed. / CJ & 43 & $65 \%$ \\
\hline Em situação de risco & 2 & $3 \%$ \\
\hline Abrigo & 8 & $12 \%$ \\
\hline LAC & 4 & $6 \%$ \\
\hline \multicolumn{3}{|l|}{ Localização } \\
\hline Zona Norte & 6 & $9 \%$ \\
\hline Zona Sul & 28 & $42 \%$ \\
\hline Zona Leste & 17 & $26 \%$ \\
\hline Zona Oeste & 13 & $20 \%$ \\
\hline Centro & 2 & $3 \%$ \\
\hline \multicolumn{3}{|l|}{ Órgãos estatutários } \\
\hline Assembléia & 59 & $89 \%$ \\
\hline Diretoria & 62 & $94 \%$ \\
\hline Diretoria & 45 & $68 \%$ \\
\hline Diretoria executiva / adm. & 17 & $26 \%$ \\
\hline Conselhos & 31 & $47 \%$ \\
\hline Deliberativo & 10 & $15 \%$ \\
\hline Administração & 3 & $5 \%$ \\
\hline Diretor & 4 & $6 \%$ \\
\hline Consultivo & 9 & $14 \%$ \\
\hline Outros tipos & 9 & $14 \%$ \\
\hline Mais de um conselho & 8 & $12 \%$ \\
\hline Conselho Fiscal & 55 & $83 \%$ \\
\hline
\end{tabular}




\begin{tabular}{|c|c|c|c|c|c|c|c|c|c|c|c|c|c|c|c|c|c|c|c|c|c|}
\hline $\begin{array}{c}\text { ENTIDAD } \\
\mathrm{E}\end{array}$ & ZONA & $\begin{array}{c}\text { Fundaçã } \\
0\end{array}$ & Idade & Diretoria & $\begin{array}{c}\text { TIPO DE } \\
\text { CONSELHO }\end{array}$ & $\begin{array}{c}\text { Nr. } \\
\text { Consel } \\
\text { heiros }\end{array}$ & $\begin{array}{l}\text { Mand } \\
\text { ato } \\
\text { (anos) }\end{array}$ & $\begin{array}{c}\text { Reuniõe } \\
\text { s } \\
\text { (vezes/a } \\
\text { no) }\end{array}$ & $\begin{array}{l}\text { Atendi } \\
\text { mento }\end{array}$ & $\begin{array}{c}\text { Orçamento } \\
\text { anual } \\
\mathrm{R} \$\end{array}$ & $\begin{array}{c}\text { Funcion } \\
\text { ários }\end{array}$ & $\begin{array}{c}\text { Unida } \\
\text { des }\end{array}$ & $\begin{array}{l}\text { Prêmio } \\
\text { Bem } \\
\text { Eficient } \\
\text { e (1999 } \\
\text { a 2001) }\end{array}$ & $\begin{array}{l}\text { Conv } \\
\text { eniad } \\
\text { a }\end{array}$ & Site & Vídeo & $\begin{array}{l}\text { Relató } \\
\text { rio } \\
\text { anual }\end{array}$ & $\begin{array}{c}\text { Folhet } \\
0 \\
\text { instituc } \\
\text { ional }\end{array}$ & $\begin{array}{l}\text { Utilidade } \\
\text { Municip } \\
\text { al }\end{array}$ & $\begin{array}{l}\text { Utilidade } \\
\text { Estadual }\end{array}$ & $\begin{array}{l}\text { Utilidade } \\
\text { Federal }\end{array}$ \\
\hline 1 & Oeste & 1986 & 14 & Não & Administração & 8 & 3 & 4 & 900 & 960.000 & 120 & 10 & & Sim & Sim & Não & Não & Sim & Sim & Não & Sim \\
\hline 2 & Sul & 1986 & 14 & Sim & Diretor & 30 & 3 & 2 & 211 & 720.000 & 100 & 1 & 1 & Sim & Sim & Sim & Sim & Não & Sim & Sim & Sim \\
\hline 3 & Norte & 1942 & 58 & Sim & $\begin{array}{c}\text { Deliberativo e } \\
\text { consultivo }\end{array}$ & 21 & 3 & 4 & 2000 & 2.641 .406 & 283 & 13 & 1 & Sim & Sim & Sim & Não & Sim & Sim & Sim & Sim \\
\hline 4 & Sul & 1993 & 7 & Não & Administração & 5 & 3 & $n / d$ & 320 & 768.000 & 60 & 2 & & Sim & Sim & Sim & Sim & Sim & Sim & Não & Sim \\
\hline 5 & Leste & 1983 & 17 & Sim & Deliberativo & 7 & 2 & 6 & 350 & 1.000 .000 & 65 & 4 & & Não & $\operatorname{sim}$ & Não & Sim & Sim & Sim & Sim & Sim \\
\hline 6 & Oeste & 1993 & 7 & Sim & Administração & 18 & 2 & 12 & 180 & 276.000 & 17 & 1 & & Sim & Não & Sim & Não & Sim & Sim & Sim & Sim \\
\hline 7 & Sul & 1957 & 43 & Sim & Consultivo & 10 & 3 & 12 & 68841 & 2.000 .000 & 80 & 1 & 2 & Não & $\operatorname{sim}$ & Sim & Sim & Sim & Sim & Sim & Sim \\
\hline 8 & Sul & 1990 & 10 & Sim & $\begin{array}{l}\text { Administração } \\
\text { e consultivo }\end{array}$ & 18 & 3 & 4 & 750000 & 10.000 .000 & 70 & 1 & 2 & - & Sim & Sim & Sim & Sim & Sim & Sim & Sim \\
\hline 9 & Norte & 1998 & 2 & Sim & Curador & 6 & 2 & 4 & 230 & 500.000 & 20 & 1 & & Sim & Sim & Sim & Não & Sim & Não & Não & Não \\
\hline 10 & Leste & 1972 & 28 & Sim & Deliberativo & 33 & 9 & 3 & 120 & 420.000 & 40 & 1 & & Não & Sim & Não & Não & Sim & Sim & Sim & Sim \\
\hline Total & & & & 8 & & 156 & & & 823.152 & 19.285 .406 & 855 & 35 & 4 & 6 & 9 & 7 & 5 & 9 & 9 & 7 & 9 \\
\hline Mínimo & & & 2 & & & 5 & 2 & 2 & 120 & 276.000 & 17 & 1 & & & & & & & & & \\
\hline Máximo & & & 58 & & & 33 & 9 & 12 & 750.000 & 10.000 .000 & 283 & 13 & & & & & & & & & \\
\hline Média & & & 20 & & & 16 & 3 & 6 & 82.315 & 1.928 .540 & 86 & 4 & $40 \%$ & $67 \%$ & $90 \%$ & $70 \%$ & $50 \%$ & $90 \%$ & $90 \%$ & $70 \%$ & $90 \%$ \\
\hline
\end{tabular}




\begin{tabular}{|c|c|c|c|c|c|c|c|c|}
\hline \multicolumn{2}{|c|}{ Perfil dos Conselheiros } & \multicolumn{5}{|c|}{ Rede Nossas Crianças } & \multicolumn{2}{|c|}{ Amostra de 10 entidades } \\
\hline Número & Idade & Sexo & Ocupação atual & Formação & $\begin{array}{l}\text { Tempo de casa } \\
\text { (anos) }\end{array}$ & Vínculo & $\begin{array}{l}\text { Dedicação aproximada } \\
\text { (dias/mês) }\end{array}$ & Outras características \\
\hline 1 & 35 & $\mathrm{~F}$ & pedagoga & pedagoga & 14 & Voluntária & 6 & Faz parte de um CMDCA \\
\hline 2 & 40 & M & comerciante & Adm. de Empresas & 14 & Voluntário & 12 & \\
\hline 3 & 80 & $\mathrm{~F}$ & conselheira & $\mathrm{n} / \mathrm{d}$ & 58 & Voluntária & 5 & \\
\hline 4 & 82 & $\mathrm{~F}$ & conselheira & $\mathrm{n} / \mathrm{d}$ & 57 & Voluntária & 5 & \\
\hline 5 & 46 & $\mathrm{~F}$ & diretora & psico-pedagogia & 7 & Voluntária & 22 & \\
\hline 6 & 69 & $\mathrm{~F}$ & missionária & freira & 17 & Voluntária & 22 & \\
\hline 7 & 72 & M & industrial & engenharia & 4 & Voluntário & 6 & \\
\hline 8 & 75 & M & industrial & $n / d$ & 20 & Voluntário & 8 & \\
\hline 9 & 53 & M & executivo & engenharia & 8 & Voluntário & 2 & \\
\hline 10 & 35 & M & atleta & história, ed. Física & Volunté & & Instituidor & \\
\hline 11 & 24 & $\mathrm{~F}$ & voluntária & Adm. de Empresas & 6 & Voluntária & 22 & \\
\hline Média & 56 & $55 \%$ & Mulheres & & 21 & & 10 & \\
\hline Mín. & 24 & & & & 4 & & 2 & \\
\hline Máx. & 82 & & & & 58 & & 22 & \\
\hline
\end{tabular}




\begin{tabular}{|c|c|c|c|c|c|c|c|c|}
\hline \multicolumn{4}{|c|}{ Perfil dos Executivos } & \multicolumn{3}{|c|}{ Rede Nossas Crianças } & \multicolumn{2}{|c|}{ Amostra de 10 entidades } \\
\hline Número & Idade & Sexo & Ocupação atual & Formação & $\begin{array}{c}\text { Tempo de casa } \\
\text { (anos) }\end{array}$ & Vínculo & $\begin{array}{c}\text { Dedicação } \\
\text { aproximada } \\
\text { (dias/mês) }\end{array}$ & Outras características \\
\hline 1 & 47 & $\mathrm{~F}$ & $\begin{array}{l}\text { coordenadora } \\
\text { administrativa }\end{array}$ & Direito & 14 & cedida & 22 & \\
\hline 2 & 66 & $\mathrm{~F}$ & diretora & Pedagogia & 14 & voluntária & 22 & \\
\hline 3 & 66 & $\mathrm{~F}$ & tesoureira & $\mathrm{n} / \mathrm{d}$ & 49 & voluntária & 8 & \\
\hline 4 & 46 & $\mathrm{~F}$ & gerente & psicóloga & 7 & remunerada & 22 & \\
\hline 5 & 31 & M & administrador & Economia & 4 & remunerado & 22 & \\
\hline 6 & 43 & $\mathrm{~F}$ & coord. adm. e pedagógica & Pedagogia & 2 & remunerada & 22 & Não permitiu gravar entrevista \\
\hline 7 & 60 & $\mathrm{~F}$ & direbra & - & 30 & voluntária & 22 & \\
\hline 8 & 43 & $\mathrm{~F}$ & superintendente & Sociologia & 10 & remunerada & 22 & \\
\hline 9 & 48 & $\mathrm{~F}$ & coord. Projetos & Letras & 2 & remunerada & 22 & \\
\hline 10 & 58 & $\mathrm{~F}$ & diretora executiva & Magistério & 28 & remunerada & 22 & \\
\hline Média & 51 & $90 \%$ & Mulheres & & 16 & & 21 & \\
\hline Mín. & 31 & & & & 2 & & 8 & \\
\hline Máx. & 66 & & & & 49 & & 22 & \\
\hline
\end{tabular}




\title{
7.2 INSTRUMENTOS
}

\section{Protocolo de ENTREVISTA PARA INCIDENTES CRÍticos}

\section{ROTEIRO PARA CONSELHEIROS}

\author{
Baseado em roteiro gentilmente cedido por: \\ Prof. Thomas P. Holland \\ Institute for Nonprofit Organizations \\ The University of Georgia \\ Agosto/2000

\section{Introdução}

Eu sou...

Estou tentando aprender sobre o que torna um conselho diretor eficaz no Brasil. Na conclusão do projeto quero descrever como opera um conselho eficaz no nosso país, além de identificar os fatores que contribuem mais significativamente para a eficácia de um conselho. Essa informação poderá ser útil para que conselhos melhorem seu desempenho e dessa forma fortaleçam suas organizações.

O estudo engloba organizações similares em escopo e missão. Ele terá caráter exploratório e serão realizadas duas entrevistas: com um conselheiro influente e com a principal liderança executiva da organização. O pressuposto é que pessoas como você estão na melhor posição para comentar sobre o que faz um conselho se tornar mais ou menos eficaz.

Esta entrevista deve durar cerca de uma hora. Serão feitas anotações para eu poder escrever futuramente sobre 0 assunto. Tudo que for dito será considerado confidencial. Sua organização será identificada como participante do projeto, mas todo o material usado no estudo será apresentado de uma fo rma que não permita a identificação de qualquer instituição ou pessoa.

A entrevista está dividida em duas partes: na primeira, vamos conversar sobre alguns casos reais de atuação do Conselho da sua organização; na segunda, será respondido um questionário de múltipla escolha.

Antes de começarmos, você tem alguma pergunta sobre o trabalho?

\section{Contexto}

Não esquecer de colocar data da entrevista e gravá -la.

Solicitar nome completo, função na organização, voluntário ou remunerado, endereço, telefone e email para entrar em contato, caso necessário.

Qual era a sua ligação com a organização antes de se tornar conselheiro?

Quando você veio a fazer parte do conselho?

Como foi este processo de tornar-se conselheiro? 
Quais foram as principais razões para que você fosse convidado a fazer parte do conselho?

Em quais organizações, sem ou com fins lucrativos, você já fez parte uma diretoria ou conselho anteriormente?

\section{Troca}

Quais foram as principais razões que o levaram a aceitar fazer parte do conselho?

Quais são os aspectos que geram mais satisfação ou realização por ser membro do conselho?

Quando seu mandato terminar, você concordaria em continuar? Por quê?

Quais são os aspectos mais frustrantes ou desapontadores por ser membro do conselho?

\section{Incidentes críticos}

Para nós, é mais fácil formar uma imagem clara de como um conselho trabalha discutindo situações bem concretas.

Você poderia, por favor, procurar lembrar-se de 3-4 situações chaves ou críticas, dos últimos 2 a 3 anos, nas quais você acha que o conselho foi particularmente efetivo ao lidar com um problema importante?

Oferecer papel e caneta para anotações e esperar alguns minutos para o entrevistado preparar-se.

Sugerir começar com o evento mais recente.

Começando com o evento mais recente...

Quando ele ocorreu?

Quais foram as circunstâncias, o contexto que o levaram a ocorrer?

Por favor, descreva o evento em detalhes.

A quê ele se referia?

Quem estava envolvido?

Por favor, descreva em detalhes o envolvimento do conselho.

Quando o conselho tornou-se envolvido?

Como o conselho tornou -se envolvido?

Como foi o envolvimento do conselho: parcial (certos conselheiros) ou total (o conselho como um todo)?

Por que o conselho tornou-se envolvido?

O que especificamente o conselho fez ao lidar com esta situação?

Quais foram as ações do conselho?

O que foi dito pelo conselho para quem?

Como foi decidido quem diria ou faria o quê?

O que, para você, o conselho queria conseguir com esta situação? 
Por que você considera que neste evento o conselho foi eficaz?

O que tornou o conselho capaz de lidar com esta situação de maneira efetiva?

Refazer as mesmas perguntas para os outros eventos selecionados.

\section{Liderança}

Como você caracteriza o estilo de trabalho do conselho?

Qual a importância do conselho para o que acontece nesta organização?

Qual a importância do presidente do conselho para o que acontece na organização?

Como você descreve a relação entre a principal liderança do conselho e a principal liderança executiva?

Qual você considera o maior erro que este conselho já fez? Se isso fosse acontecer de novo, o que seria diferente?

\section{Avaliação}

Solicitar ao entrevistado que responda o questionário para avaliação do desempenho do conselho.

O que mais você gostaria de comentar sobre o trabalho do conselho desta organização?

\section{Conclusão}

O que mais você gostaria de comentar, esclarecer ou adicionar sobre eficácia de conselhos?

Muito obrigado! Prometer enviar uma cópia do resultado final da pesquisa. 


\section{Protocolo de Entrevista para Incidentes Críticos \\ ROTEIRO PARA EXECUTIVOS}

Baseado em roteiro gentilmente cedido por:

Prof. Thomas P. Holland

Institute for Nonprofit Organizations

The University of Georgia

Agosto/2000

\section{Introdução}

Eu sou...

Estou tentando aprender sobre o que torna um conselho diretor eficaz no Brasil. Na conclusão do projeto quero descrever como opera um conselho eficaz no nosso país, além de identificar os fatores que contribuem mais significativamente para a eficácia de um conselho. Essa informação poderá ser útil para que conselhos melhorem seu desempenho e dessa forma fortaleçam suas organizações.

O estudo engloba organizações similares em escopo e missão. Ele terá caráter exploratório e serão realizadas duas entrevistas: com um conselheiro influente e com a principal liderança executiva da organização. O pressuposto é que pessoas como você estão na melhor posição para comentar sobre o que faz um conselho se tornar mais eficaz.

Esta entrevista deve durar cerca de uma hora a uma hora e meia. Serão feitas anotações para eu poder escrever futuramente sobre o assunto. Tudo que for dito será considerado confidencial. A organização será identificada como participante do projeto, mas todo o material usado no estudo será apresentado de uma forma que não permita a identificação de qualquer instituição ou pessoa.

A entrevista está dividida em duas partes: na pimeira, vamos conversar sobre alguns casos reais de atuação do conselho da sua organização; na segunda, será respondido um questionário de múltipla escolha.

Antes de começarmos, você tem alguma pergunta sobre o trabalho?

\section{Contexto}

Não esquecer de colocar data da entrevista e gravá-la.

Solicitar nome completo, função na organização, voluntário ou remunerado, endereço, telefone e e mail para entrar em contato, caso necessário.

Por favor, informe alguns dados da sua organização em que faz parte como executivo:

Nome da organização, ano de fundação, endereço, telefone, e -mail, home page

Tipo de entidade, público -alvo principal, quantidade atendida, número de unidades

Estrutura organizacional, número de funcionários, orçamento anual, utilidade pública 
Faz relatório anual? Folheto institucional? Vídeo institucional?

Número atual de conselheiros, duração do mandato, freqüência das reuniões

Perfil geral dos conselheiros

É possível conseguir uma cópia dos estatutos?

Qual era a sua ligação com a organização antes de se tornar executivo?

Quando você veio a tomar contato com o conselho?

Como foi este processo de tomar contato com o conselho?

Quais foram as principais razões para que você fosse convidado a trabalhar na organização? E a trabalhar com o conselho?

Em quais organizações, sem ou com fins lucrativos, você já fez parte uma diretoria ou conselho anteriormente?

\section{Troca}

Quais foram as principais razões que o levaram a aceitar fazer parte desta organização?

Quais são os aspectos que geram mais satisfação ou realização no seu trabalho como liderança executiva?

Por quanto tempo você pretende continuar nesta organização? Por quê?

Quais são os aspectos mais frustrantes ou desapontadores no seu trabalho como liderança executiva?

\section{Incidentes críticos}

Para nós, é mais fácil formar uma imagem clara de como um conselho trabalha discutindo situações bem concretas.

Você poderia, por favor, procurar lembrar-se de 3-4 situações chaves ou críticas, dos últimos 2 a 3 anos, nas quais você acha que o conselho foi particularmente efetivo ao lidar com um problema importante?

Oferecer papel e caneta para anotações e esperar alguns minutos para o entrevistado preparar-se.

Sugerir começar com o evento mais recente.

Começando com o evento mais recente...

Quando ele ocorreu?

Quais foram as circunstâncias, o contexto que o levaram a ocorrer?

Por favor, descreva o evento em detalhes.

A quê ele se referia?

Quem estava envolvido?

Por favor, descreva em detalhes o envolvimento do conselho.

Quando o conselho tornou-se envolvido?

Como o conselho tornou -se envolvido? 
Como foi o envolvimento do conselho: parcial (certos conselheiros) ou total (o conselho como um todo)?

Por que o conselho tornou-se envolvido?

O que especificamente o conselho fez ao lidar com esta situação?

Quais foram as ações do conselho?

O que foi dito pelo conselho para quem?

Como foi decidido quem diria ou faria o quê?

O que, para você, o conselho queria conseguir com esta situação?

Por que você considera que neste evento o conselho foi eficaz?

O que tornou o conselho capaz de lidar com esta situação de maneira efetiva?

Refazer as mesmas perguntas para os outros eventos selecionados.

\section{Liderança}

Como você caracteriza o estilo de trabalho do conselho?

Qual a importância do conselho para o que acontece nesta organização?

Qual a importância do presidente do conselho para o que acontece na organização?

Como você descreve a relação entre a principal liderança do conselho e a principal liderança executiva?

Qual você considera o maior erro que este conselho já fez? Se isso fosse acontecer de novo, o que seria diferente?

\section{Avaliação}

Solicitar ao entrevistado que responda o questionário para avaliação do desempenho do conselho.

O que mais você gostaria de comentar sobre o trabalho do conselho desta organização?

\section{Conclusão}

O que mais você gostaria de comentar, esclarecer ou adicionar sobre eficácia de conselhos?

Muito obrigado! Prometer enviar uma cópia do resultado final da pesquisa. 


\title{
QuestionáRIO de Auto-Avaliação do Conselho ${ }^{73}$
}

\section{Nome da organização:}

Data:

Obrigado por participar deste estudo sobre Conselhos de organizações sem fins lucrativos no Brasil. As afirmações a seguir descrevem uma variedade de possíveis ações dos Conselhos. Para cada um dos itens existem 4 escolhas possíveis:
a) Nunca
b) Raramente ou æ̀ vezes
c) Freqüentemente ou quase sempre
d) Sempre

Por favor, marque com um $\mathrm{X}$ a escolha que mais corretamente descreve suas observações junto ao trabalho do Conselho. Para que o resultado seja o mais real possível, por favor:

$\Rightarrow \quad$ Marque apenas um X por linha;

$\Rightarrow$ Se por qualquer motivo não for possível responder a uma questão, deixe em branco aquela alternativa;

$\Rightarrow$ Evite falar do que é ideal ou recomendado, restrinja-se a falar somente sobre aquilo que efetivamente acontece na prática, aquilo que você observou;

$\Rightarrow$ Procure avaliar o comportamento do Conselho como um todo, evite caracterizar o comportamento de um ou dois conselheiros somente.

De forma a garantir a confidencialidade de todas as respostas, por favor não coloque seu nome em lugar nenhum deste formulário. Depois que tiver completado todos os itens, por favor entregue-o àpessoa re sponsável.

\author{
Muito obrigado! \\ Antonio Luiz de Paula e Silva \\ Mestrando FEA-USP \\ Tel.: 9103-9105 \\ alpsilva@christophorus.org
}

\footnotetext{
${ }^{73}$ Desenvolvido a partir de CHAIT, HOLLAND \& TAYLOR, 1991
} 


\begin{tabular}{|c|c|c|c|c|}
\hline Questionário de Auto-Avaliação do Conselho & Nunca & $\begin{array}{l}\text { RARAMENTE } \\
\text { OU Â ÀS VEZES }\end{array}$ & $\begin{array}{l}\text { FREQÜENTEM } \\
\text { ENTE/ QUASE } \\
\text { SEMPRE }\end{array}$ & SEMPRE \\
\hline $\begin{array}{l}\text { 1. O Conselho pede que uma decisão seja adiada até que } \\
\text { mais informação possa ser obtida }\end{array}$ & & & & \\
\hline $\begin{array}{l}\text { 2. Nas reuniões do Conselho, as recomendações da } \\
\text { direção executiva são aceitas somente depois de um } \\
\text { bom questionamento }\end{array}$ & & & & \\
\hline $\begin{array}{l}\text { 3. O Conselho utiliza-se de dados, indicadores, } \\
\text { avaliações e pesquisas para tomar decisões }\end{array}$ & & & & \\
\hline $\begin{array}{l}\text { 4. O Conselho busca informações e conselhos de } \\
\text { lideranças e especialistas externos }\end{array}$ & & & & \\
\hline $\begin{array}{l}\text { 5. Em questões importantes, o Conselho faz algo como } \\
\text { uma chuva de idéias e examina várias alternativas de } \\
\text { solução }\end{array}$ & & & & \\
\hline $\begin{array}{l}\text { 6. O Conselho faz perguntas e comentários como se } \\
\text { fosse membro de diferentes audiências da organização }\end{array}$ & & & & \\
\hline $\begin{array}{l}\text { 7. O Conselho faz perguntas para provocar a emergência } \\
\text { e a discussão de opiniões diferentes }\end{array}$ & & & & \\
\hline $\begin{array}{l}\text { 8. Diferenças de opinião dentro do Conselho são } \\
\text { resolvidas com informação e argumentos, não por } \\
\text { voto }\end{array}$ & & & & \\
\hline $\begin{array}{l}\text { 9. O Conselho levanta perguntas difíceis de serem } \\
\text { respondidas, que exigem pensar muito }\end{array}$ & & & & \\
\hline $\begin{array}{l}\text { 10. O Conselho faz perguntas para relacionar os temas } \\
\text { discutidos à organização toda e a um sistema maior }\end{array}$ & & & & \\
\hline $\begin{array}{l}\text { 11. O Conselho lista os riscos econômicos, financeiros e } \\
\text { jurídicos que uma decisão importante pode trazer }\end{array}$ & & & & \\
\hline $\begin{array}{l}\text { 12. O Conselho lista os riscos políticos, humanos e sociais } \\
\text { que uma decisão importante pode trazer }\end{array}$ & & & & \\
\hline Sub-total 1 a $12-A n$ & $-\times 1=$ & $-\times 2=$ & $\ldots \times 3=$ & $\ldots \times 4=$ \\
\hline
\end{tabular}




\begin{tabular}{|c|c|c|c|c|}
\hline Questionário de Auto-Avaliação do Conselho & Nunca & $\begin{array}{l}\text { RARAMENTE } \\
\text { OU ÀS VEZES }\end{array}$ & $\begin{array}{l}\text { FREQÜENTEM } \\
\text { ENTE/ QUASE } \\
\text { SEMPRE }\end{array}$ & SEMPRE \\
\hline $\begin{array}{l}\text { 13. Novos conselheiros recebem uma explicação } \\
\text { detalhada da missão e das tradições da organização }\end{array}$ & & & & \\
\hline $\begin{array}{l}\text { 14. Membros do Conselho falam para novos conselheiros } \\
\text { sobre a cultura e a filosofia da organização }\end{array}$ & & & & \\
\hline $\begin{array}{l}\text { 15. Os conselheiros fazem visitas aos projetos e } \\
\text { conversam com a equipe e os clientes sobre a } \\
\text { organização }\end{array}$ & & & & \\
\hline $\begin{array}{l}\text { 16. O Conselho examina casos concretos de atuação da } \\
\text { entidade para poder entendê-la melhor }\end{array}$ & & & & \\
\hline $\begin{array}{l}\text { 17. O Conselho participa de eventos e reuniões para } \\
\text { aprender mais sobre temas que afetam a organização }\end{array}$ & & & & \\
\hline $\begin{array}{l}\text { 18. O Conselho faz reuniões específicas para revisar e } \\
\text { nutrir a missão, os valores e a filosofia da entidade }\end{array}$ & & & & \\
\hline $\begin{array}{l}\text { 19. O Conselho discute explicitamente a história, a missão } \\
\text { ou os valores da instituição para tomar decisões }\end{array}$ & & & & \\
\hline $\begin{array}{l}\text { 20. Nas reuniões, o Conselho cita e discute as principais } \\
\text { características distintivas da organiz ação }\end{array}$ & & & & \\
\hline $\begin{array}{l}\text { 21. As questões apresentadas ao Conselho são colocadas } \\
\text { explicitando as ligações com a estratégia da entidade }\end{array}$ & & & & \\
\hline $\begin{array}{l}\text { 22. O Conselho pergunta o que o comportamento das } \\
\text { pessoas transmite da filosofia/prioridades da entidade }\end{array}$ & & & & \\
\hline $\begin{array}{l}\text { 23. O Conselho faz muitas perguntas do tipo "Por quê?" e } \\
\text { "Para quê?" antes de fazer sugestões e propostas }\end{array}$ & & & & \\
\hline $\begin{array}{l}\text { 24. O Conselho pede informações sobre o perfil da equipe } \\
\text { e o ambiente interno antes de tomar decisões }\end{array}$ & & & & \\
\hline Sub-total 13 a 24 - Co & $\ldots \times 1=$ & $\ldots \times 2=$ & $\ldots 3=$ & $\ldots \times 4=$ \\
\hline
\end{tabular}




\begin{tabular}{|c|c|c|c|c|}
\hline Questionário de Auto-Avaliação do Conselho & Nunca & $\begin{array}{l}\text { RARAMENTE } \\
\text { OU ÀS VEZES }\end{array}$ & $\begin{array}{l}\text { FREQÜENTEM } \\
\text { ENTE/ QUASE } \\
\text { SEMPRE }\end{array}$ & SEMPRE \\
\hline $\begin{array}{l}\text { 25. Uma ata detalhada das reuniões é enviada a todos os } \\
\text { conselheiros }\end{array}$ & & & & \\
\hline $\begin{array}{l}\text { 26. O Conselho fornece e atualiza uma pasta para cada } \\
\text { conselheiro com informações sobre a organização }\end{array}$ & & & & \\
\hline $\begin{array}{l}\text { 27. O Conselho reserva tempo para conselheiros fazerem } \\
\text { exposições sobre temas específicos }\end{array}$ & & & & \\
\hline 28. O Conselho faz avaliação ao final das suas reuniões & & & & \\
\hline $\begin{array}{l}\text { 29. O Conselho faz reuniões para avaliar o desempenho e } \\
\text { a eficácia do trabalho do Conselho }\end{array}$ & & & & \\
\hline $\begin{array}{l}\text { 30. O Conselho sugere nomes de conselheiros para } \\
\text { auxiliar em atividades específicas na instituição }\end{array}$ & & & & \\
\hline $\begin{array}{l}\text { 31. O Conselho pergunta-se quais os erros que cometeu } \\
\text { num certo período e o que pode aprender deles }\end{array}$ & & & & \\
\hline $\begin{array}{l}\text { 32. O Conselho pede para pessoas da organização e de } \\
\text { fora dizerem como avaliam o trabalho do Conselho }\end{array}$ & & & & \\
\hline $\begin{array}{l}\text { 33. Cada conselheiro recebe comentários sobre seu } \\
\text { desempenho como membro do Conselho }\end{array}$ & & & & \\
\hline $\begin{array}{l}\text { 34. O Conselho promove palestras, visitas e cursos para } \\
\text { educação e capacit ação dos conselheiros }\end{array}$ & & & & \\
\hline $\begin{array}{l}\text { 35. Conselheiros convidam conselheiros para participar } \\
\text { de eventos educativos ou de capacitação }\end{array}$ & & & & \\
\hline $\begin{array}{l}\text { 36. Os conselheiros indicam e compartilham entre si } \\
\text { textos e material educacional, como livros e vídeos }\end{array}$ & & & & \\
\hline Sub-total 25 a 36 - Ed & $\ldots \times 1=$ & $-\times 2=$ & $\ldots 3=$ & $\ldots \times 4=$ \\
\hline
\end{tabular}




\begin{tabular}{|c|c|c|c|c|}
\hline Questionário de Auto-Avaliação do Conselho & Nunca & $\begin{array}{l}\text { RARAMENTE } \\
\text { OU ÀS VEZES }\end{array}$ & $\begin{array}{l}\text { FREQÜENTEM } \\
\text { ENTE/ QUASE } \\
\text { SEMPRE }\end{array}$ & SEMPRE \\
\hline $\begin{array}{l}\text { 37. O Conselho discute fatos e tendências mundiais e } \\
\text { locais que podem ser importantes para a entidade }\end{array}$ & & & & \\
\hline $\begin{array}{l}\text { 38. Os con selheiros falam sobre sua visão de como estará } \\
\text { a comunidade e o mundo daqui a alguns anos }\end{array}$ & & & & \\
\hline $\begin{array}{l}\text { 39. O Conselho pede à liderança executiva para expressar } \\
\text { sua visão do futuro e das estratégias para realizá-la }\end{array}$ & & & & \\
\hline $\begin{array}{l}\text { 40. O Conselho discute tendências de mudanças nas } \\
\text { principais características e necessidades do público- } \\
\text { alvo }\end{array}$ & & & & \\
\hline $\begin{array}{l}\text { 41. O Conselho explicitamente identifica e discute a } \\
\text { superação de pontos fracos da organização }\end{array}$ & & & & \\
\hline $\begin{array}{l}\text { 42. O Conselho lista possíveis prioridades da organização } \\
\text { e ordena-as em ordem de importância para o fut uro }\end{array}$ & & & & \\
\hline $\begin{array}{l}\text { 43. O Conselho pergunta-se porque determinada questão é } \\
\text { importante para o futuro da organização e seu público }\end{array}$ & & & & \\
\hline $\begin{array}{l}\text { 44. Conselheiros propõem que ações sejam tomadas antes } \\
\text { que a situação se torne urgente ou crítica }\end{array}$ & & & & \\
\hline $\begin{array}{l}\text { 45. Para deliberar sobre problemas atuais, o Conselho } \\
\text { verifica o plano institucional }\end{array}$ & & & & \\
\hline $\begin{array}{l}\text { 46. O Conselho elabora perguntas e sugestões para } \\
\text { auxiliar a equipe executiva no planejamento }\end{array}$ & & & & \\
\hline $\begin{array}{l}\text { 47. O Conselho pede à liderança executiva que apresente } \\
\text { questões para orientar a atenção do Conselho }\end{array}$ & & & & \\
\hline $\begin{array}{l}\text { 48. O Conselho propõe alguns indicadores a serem } \\
\text { monitorados sobre o desempenho da organização }\end{array}$ & & & & \\
\hline Sub-total 37 a 48 - Es & $\ldots \times 1=$ & $-\times 2=$ & $\ldots 3=$ & $\ldots \times 4=$ \\
\hline
\end{tabular}




\begin{tabular}{|c|c|c|c|c|}
\hline Questionário de Auto-Avaliação do Conselho & Nunca & $\begin{array}{l}\text { RARAMENTE } \\
\text { OU ÀS VEZES }\end{array}$ & $\begin{array}{l}\text { FREQÜENTEM } \\
\text { ENTE/ QUASE } \\
\text { SEMPRE }\end{array}$ & SEMPRE \\
\hline $\begin{array}{l}\text { 49. Nas reuniões, somente um conselheiro fala de cada } \\
\text { vez e os outros ouvem }\end{array}$ & & & & \\
\hline $\begin{array}{l}\text { 50. Os conselheiros conversam muito entre si, não } \\
\text { somente com a liderança da reunião }\end{array}$ & & & & \\
\hline $\begin{array}{l}\text { 51. Os conselheiros expõem suas opiniões sobre temas } \\
\text { importantes, mesmo que diferentes de seus colegas }\end{array}$ & & & & \\
\hline $\begin{array}{l}\text { 52. Os conselheiros fazem perguntas para assegurar que } \\
\text { entenderam a opinião dos outros }\end{array}$ & & & & \\
\hline $\begin{array}{l}\text { 53. Questões delicadas e cruciais são tratadas com a } \\
\text { maioria dos conselheiros, mantendo ausentes } \\
\text { informados }\end{array}$ & & & & \\
\hline $\begin{array}{l}\text { 54. O Conselho estabelece metas e uma agenda de } \\
\text { trabalho para si próprio, que vai além das reuniões }\end{array}$ & & & & \\
\hline $\begin{array}{l}\text { 55. O Conselho faz reuniões específicas para tratar da sua } \\
\text { renovação e do processo de recrutar novos membros }\end{array}$ & & & & \\
\hline $\begin{array}{l}\text { 56. O Conselho estabelece critérios explícitos para } \\
\text { escolher novos membros }\end{array}$ & & & & \\
\hline $\begin{array}{l}\text { 57. Novos conselheiros são convidados a fazer parte do } \\
\text { Conselho }\end{array}$ & & & & \\
\hline $\begin{array}{l}\text { 58. Os conselheiros manifestam-se em eventos especiais } \\
\text { na vida dos membros do Conselho }\end{array}$ & & & & \\
\hline $\begin{array}{l}\text { 59. O Conselho abre espaços informais para os seus } \\
\text { membros conhecerem-se melhor }\end{array}$ & & & & \\
\hline $\begin{array}{l}\text { 60. Os conselheiros comunicam-se diretamente entre si, } \\
\text { entre as reuniões }\end{array}$ & & & & \\
\hline Sub-total 49 a 60 - In & $\ldots \times 1=$ & $-\times 2=$ & $\ldots$. $3=$ & $\ldots \times 4=$ \\
\hline
\end{tabular}




\begin{tabular}{|c|c|c|c|c|}
\hline Questionário de Auto-Avaliação do Conselho & Nunca & $\begin{array}{l}\text { RARAMENTE } \\
\text { OU ÀS VEZES }\end{array}$ & $\begin{array}{c}\text { FREQÜENTEM } \\
\text { ENTE/ QUASE } \\
\text { SEMPRE }\end{array}$ & SEMPRE \\
\hline $\begin{array}{l}\text { 61. O Conselho reconhece explicitamente que a equipe } \\
\text { executiva tem total autonomia sobre certas decisões }\end{array}$ & & & & \\
\hline $\begin{array}{l}\text { 62. Representantes das audiências da organização são } \\
\text { convidados a participar de reuniões do Co nselho }\end{array}$ & & & & \\
\hline $\begin{array}{l}\text { 63. Conselheiros relembram os vários públicos da } \\
\text { organização para deliberar sobre temas importantes }\end{array}$ & & & & \\
\hline $\begin{array}{l}\text { 64. O Conselho sugere nomes de parceiros para participar } \\
\text { do planejamento da organização }\end{array}$ & & & & \\
\hline $\begin{array}{l}\text { 65. Os conselheiros alertam quando percebem que pode } \\
\text { haver conflitos de interesses numa discussão }\end{array}$ & & & & \\
\hline $\begin{array}{l}\text { 66. O Conselho pergunta como uma ação afetará as } \\
\text { relações com audiências internas e externas à } \\
\text { organização }\end{array}$ & & & & \\
\hline $\begin{array}{l}\text { 67. O Conselho consulta diferentes públicos da instituição } \\
\text { para deliberar sobre questões que podem afetálos }\end{array}$ & & & & \\
\hline $\begin{array}{l}\text { 68. O Conselho pergunta como está o relacionamento da } \\
\text { equipe executiva com os diferentes parceiros }\end{array}$ & & & & \\
\hline $\begin{array}{l}\text { 69. Os conselheiros falam diretamente com pessoas da } \\
\text { equipe executiva e técnica }\end{array}$ & & & & \\
\hline $\begin{array}{l}\text { 70. Membros do Conselho participam de eventos } \\
\text { promovidos pela organização }\end{array}$ & & & & \\
\hline $\begin{array}{l}\text { 71. Quando há um problema interno delicado, } \\
\text { conselheiros propõem-se a trocar idéias e pensar junto }\end{array}$ & & & & \\
\hline $\begin{array}{l}\text { 72. Numa situação delicada, o Conselho pergunta-se } \\
\text { como ela pode ser resolvida sem perdedores e } \\
\text { ganhadores }\end{array}$ & & & & \\
\hline Sub-total 61 a $72-P o$ & $-\times 1=$ & $-\times 2=$ & $-\times 3=$ & $\ldots \times 4=$ \\
\hline
\end{tabular}




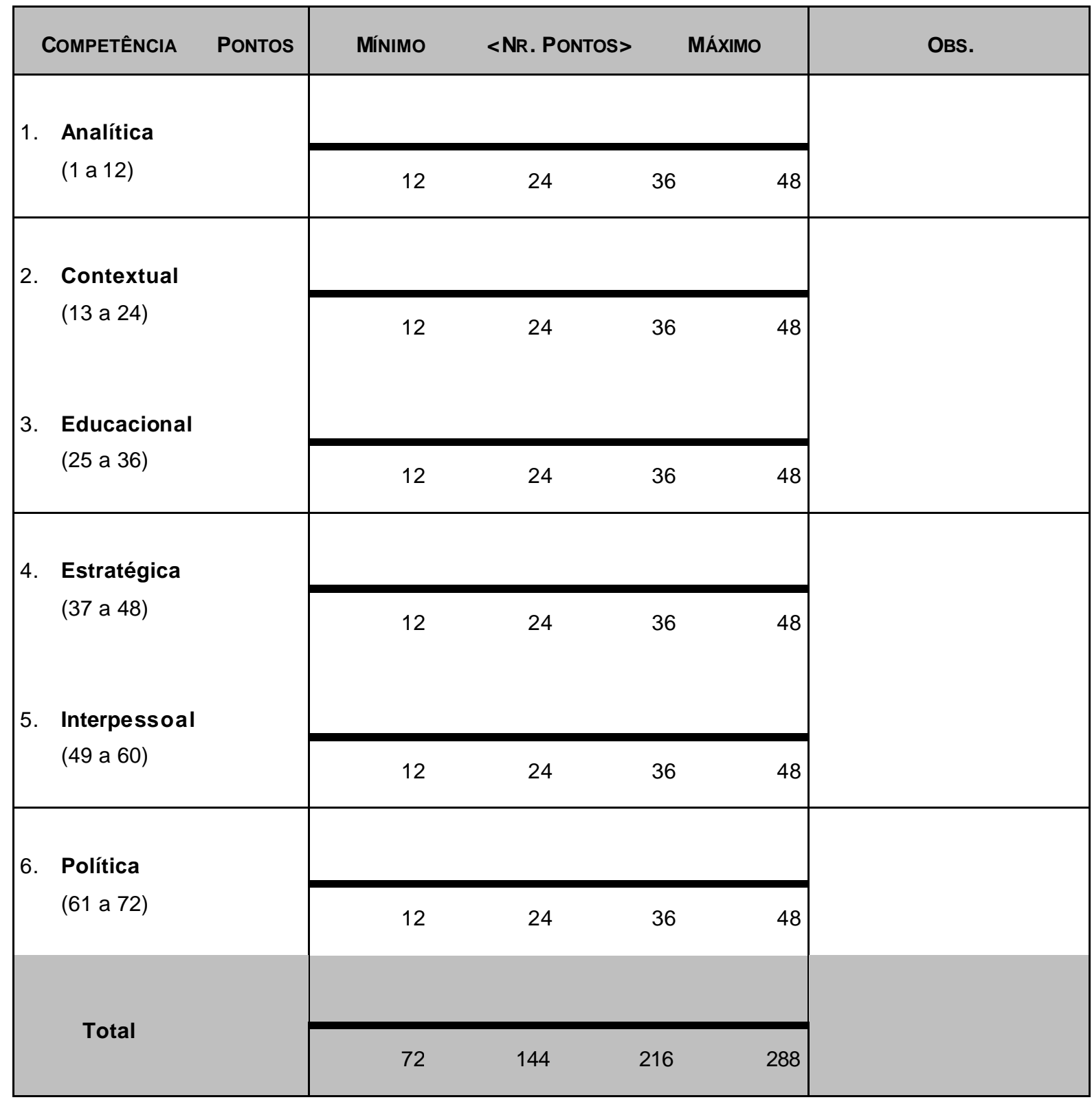

